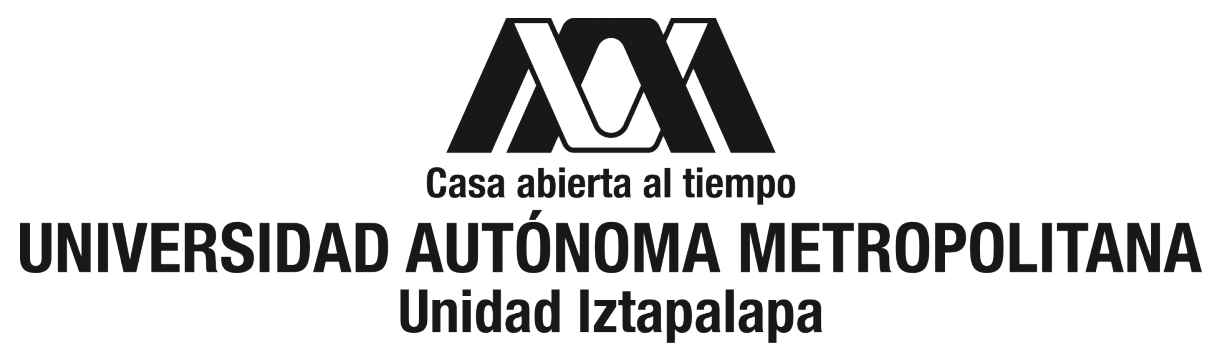

División de Ciencias Sociales y Humanidades

Doctorado en Humanidades - Filosofía Moral y Política

\title{
Pensamiento político converso en la Castilla del siglo XV y su impronta en la Modernidad hispánica: Teología política y pensamiento republicano en el Defensorium unitatis christianae de Alonso de Cartagena.
}

Beatriu Raquel Marcos Pérez

Tesis presentada para optar al grado de:

Doctora en Humanidades - Filosofía Moral y Política

Asesor de la tesis:

Dr. Jörg Alejandro Tellkamp

Sinodales:

Dr. Francisco Quijano

Dra. Teresa Santiago

Dr. Jörg Alejandro Tellkamp

Ciudad de México. Noviembre de 2018. 
A Lorenzo 


\section{ÍNDICE}

AgRAdECIMIENTOS.....................................................................

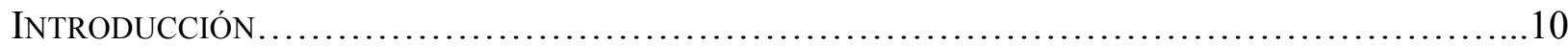

Primera PARTe. PenSAMiento Político conVERso en la CASTILla del Siglo XV.

CAPÍTUlo 1: Acotación e identificación de problemáticas en torno a las categorías de republicanismo, humanismo cívico y teología política para nuestro estudio de caso. Propuesta de denominación para el mismo: pensamiento político converso.............................27

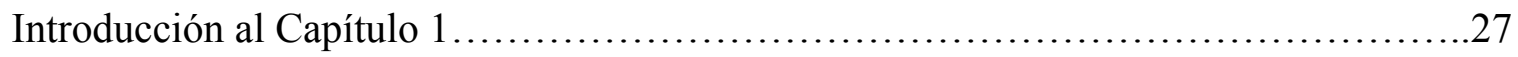

1.1 Asomarnos críticamente a ciertas categorías conceptuales imperantes y a su

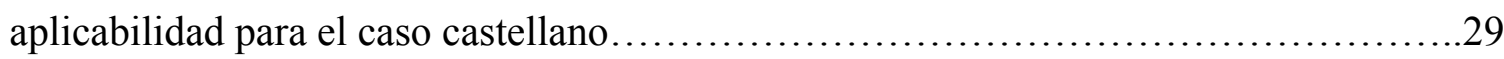

1.2 El concepto humanismo. Problematización del término para este trabajo. Una lanza a

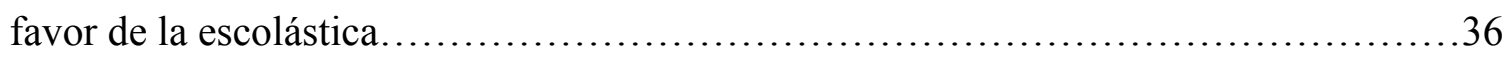

1.3 Acerca de las categorías de republicanismo y humanismo cívico. Nuestra propuesta de denominación para el caso castellano: pensamiento político converso..................45

1.3.1 ¿Cómo entendemos en esta tesis el término republicanismo?.....................46

1.3.2 Sobre la categoría humanismo cívico en la historia de la filosofía política. La tesis de Baron, su adopción por Pocock y su estela en la historia del republicanismo....................................................5

1.3.3 Problemáticas y debates académicos alrededor de esta categoría: diversas críticas al concepto de humanismo cívico...............................66 
1.3.4 Nuestra propuesta de denominación para el caso castellano: pensamiento

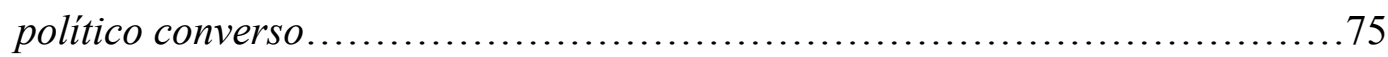

1.4 Breve apunte sobre cómo abordaremos la noción de teología política........................97

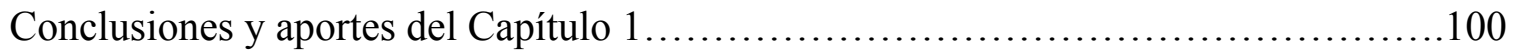

CAPítulo 2: El pensamiento político converso castellano del siglo XV y el contexto que lo

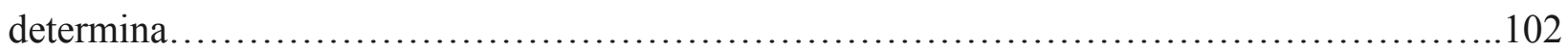

Introducción al Capítulo 2. Acerca del contexto intelectual, religioso y político-social.............................................................. 102

2.1 La cuestión conversa........................................................108

2.2 La función social del letrado................................................123

2.3 "La Primera Escuela de Salamanca”. Escolástica y pensamiento político...........126

2.4 Proto-reforma, paulinismo, organicismo teológico y conciliarismo en Castilla......132

2.5 Acerca de la noción de monarquía............................................138

2.6 El proyecto de un modelo de gobierno mixto. Las Cortes en Castilla durante el siglo XV: de las Cortes de Briviesca a la Junta de Ávila....................................156

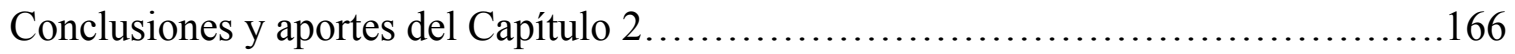


Segunda parte. Estudio de caso: El Defensorium unitatis christianae de Alonso de CARTAgena.

CAPítUlo 3: Acerca de Alonso de Cartagena y su pensamiento político

Introducción al Capítulo 3

3.1 Presentación de Alonso de Cartagena y de su producción textual. Estado de la cuestión sobre la literatura crítica en torno al autor....

3.2 Controversias respecto a la figura intelectual de Cartagena

3.3. Introducción a su pensamiento político. Acerca de su noción de monarquía y de su postura ante la cuestión del origen de la autoridad. 194

Conclusiones y aportes del Capítulo 3

CAPítulo 4: Teología política y pensamiento republicano en el Defensorium unitatis christianae (1449)

Introducción al Capítulo 4 .214

4.1 Introducción al Defensorium unitatis chistianae: apunte filológico, explicación sobre el origen de la obra, resumen e índice de autoridades .215

4.2 El valor del Defensorium. 238

4.3. Revisión teológico-histórica de la relación entre judaísmo y cristianismo. Creación de un nuevo pueblo a través de la revelación. .242

4.4 Uso de la metáfora organicista: iguala y cohesiona. .255 
4.5 Instrumentalización política de elementos teológicos para conformar una ratio de la inclusión y del acceso a la ciudadanía. El bautismo como posibilitador de participación

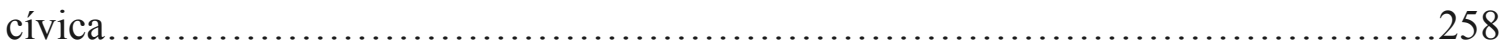

4.6 Reacción ante el uso arbitrario de la autoridad. Desactivación jurídica de los estatutos de limpieza de sangre. Deslegitimación de las políticas de segregación.................269

4.7 Impronta y marginación del pensamiento de Cartagena..........................275

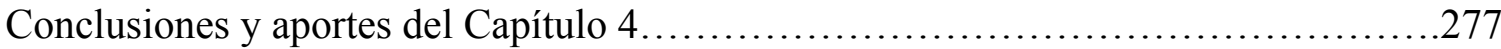

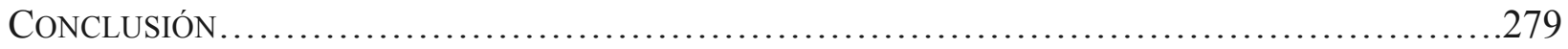

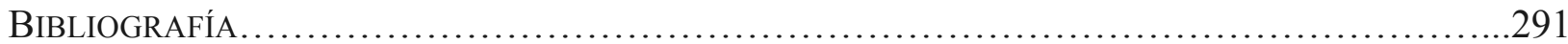




\section{AGRADECIMIENTOS}

Deseo con las siguientes palabras expresar conmovida mi agradecimiento. Es la emoción que más fuertemente siento al entregar la presente tesis doctoral. La realización de ésta ha sido factible gracias a que me fue concedida una beca pre-doctoral de una institución pública mexicana, el Consejo Nacional de Ciencia y Tecnología (CONACYT), bajo el Programa Nacional de Posgrados de Calidad. Expreso, lo primero, mi profunda gratitud a dicha institución. Quiero dar también unas gracias enormes a México por su generosidad inmensa conmigo: es gracias a este pueblo, y a su excelente universidad pública, en concreto la Universidad Autónoma Metropolitana, que he podido encarnar el sueño de hacer mi doctorado. Por ello hago extensiva mi gratitud a cada ciudadano mexicano que con su esfuerzo y trabajo cotidiano me ha permitido este privilegio, espero de veras haber estado a la altura y poder retribuirles tal apoyo. Cuenten con mi firme compromiso por contribuir a una sociedad más justa.

Esta tesis doctoral ha supuesto un fascinante viaje intelectual, pero también en muchos aspectos una durísima travesía. Ha implicado una migración, muchos momentos de inseguridad, angustia y desaliento, un tan obligado como pernicioso aislamiento, y un gran esfuerzo de disciplina e introspección, pero sobre todo ha supuesto afianzar mi infinito agradecimiento por las personas tan maravillosas que la vida me va regalando. Quiero explicitar ante todo el agradecimiento a mi esposo Lorenzo Fusaro - por descubrirme lo insondable, paciente y tierno que puede ser el amor, así como por ser siempre un altísimo referente intelectual y humano, y por resultar el mejor compañero de vida imaginable—, y a mi queridísima familia, Mamá, Papá,

y mi hermano Jaume - por el apoyo, el cuidado, la confianza, y la entrega incondicionales de toda una vida, además de por transmitirme desde pequeña la ética, la empatía hacía el otro, la curiosidad, la belleza y la apertura de mente como pilares; además de por la comprensión y respeto siempre con mis decisiones de vida - Expresar sobre todo mi gratitud a mi madre, Elisa, por ser un ejemplo de mujer, de amor, lucha y sacrificio (pienso mucho, asimismo, al escribir esto en mis dos abuelas, Elisa, 'Mami' — de quien tanto aprendí- y Pura, 'la Yaya', y en mi tía Rosa María); mi madre dejó su Puerto Rico natal para hacer una tesis doctoral en España que, simbólicamente, termino yo hoy, y en México. También dar las gracias a mi cuñada Nina Schmitt-Nilson (y a mi pequeña sobrina Olivia), así como a Mariana Rodríguez, por querer tanto 
ambas, respectivamente, a mi hermano y a mi padre, Jaime, quien es todo sensibilidad e integridad. Y a mi familia política, siempre tan acogedora, amorosa y generosa conmigo, además de ser bellísimas personas. Asimismo, a mi familia extendida de España y Puerto Rico. A lo largo de este proceso, mis amigas del alma — pese a la distancia física - me han sostenido y escuchado con una solidaridad y cariño incansables (gracias de corazón, os quiero mucho, Laura Vispe, Pilar Domínguez, Dafne Zorrilla, María Mancha, Leticia de la Puente, Susana Araujo, Clara Ruiz, Sara García, Mage Allegue, Cristina Barroso, Ana Sofía Cabello, etc). Un abrazo agradecido también a tantos maravillosos amigos de siempre en España, de antes en Perú y de ahora en México (no puedo nombraros aquí a todos, que sois uno de mis mayores tesoros, pero estáis en mi pensamiento). Sí quisiera nombrar, por lo cercanos al proceso de esta tesis, a mis fabulosos compañeros de tantas horas de biblioteca en el Colegio de México (institución a la que agradezco el permitirme usar sus instalaciones y fondos), Patricia Oliver y Conrado J. Arranz, y a María Cruz La Chica. Quiero mencionar también mi gran gratitud personal e intelectual a Gabriel Arriarán, y también a José Luis Aguilera, Martín Guerra, Adrián Matellanes, Ginés Casanova y Jaime Jiménez Llorente, que en distintos momentos de mi vida fueron luminarias.

Uno de los patrimonios más hermosos que podemos tener es la admiración por otros: en mi camino intelectual he tenido la fortuna de cruzarme con personas de una extraordinaria bondad y lucidez, y muchas de ellas —algunas, quizá, incluso sin saberlo- han sido determinantes para envalentonarme a hacer esta tesis, y se han tornado, además, figuras dignas de emular, lo cual es también un acicate en momentos de flaqueza. En este sentido, a quien primero quiero expresar mi profundísimo agradecimiento y cariño es a mi maestro Carlos Thiebaut (sin él, literalmente, el hacer este doctorado nunca hubiera acontecido), su sabiduría y calado humano son un estímulo e inspiración de vida constantes para mí; además, ha realizado una fértil lectura de esta tesis, abriéndole preciosas vetas. También en mi paso por la Maestría en 'Teoría y Crítica de la Cultura' de la Universidad Carlos III de Madrid tuve el hallazgo asombroso de encontrar un grupo de profesores cuya dimensión intelectual, personal y militante, me devolvió la ilusión por regresar a la academia tras varios años trabajando en el ámbito de la cooperación internacional; mil gracias también, Fernando Broncano, Antonio Valdecantos, Rocío Orsi, José Medina, Antonio Gómez Ramos, Carmen González Marín, Antonio Rodríguez de las Heras, Julio Checa, Remedios Zafra, Javier Moscoso, Juan Martín Prada, etc. Asimismo, 
en las Facultades de Filología y Filosofía de la Universidad Complutense, a lo largo de los años, he encontrado a profesores excepcionales. El poso de todos ellos reverbera en esta tesis, no es en absoluto sólo labor y mérito mío: puedo decir con emoción que pertenezco a una tradición intelectual aprendida ahí. Recordar también a Alberto Portera, José Luis López Aranguren o Carlos Bousoño, a quienes tuve en mi temprana juventud la suerte de tratar y quienes supusieron un despertar para mí. Siguiendo con el agradecimiento a admirados profesores que me han ayudado a encauzar esta tesis, no puedo dejar de nombrar a José Luis Villacañas (que sin conocerme, me recibió varias veces con gran generosidad, y cuyo pensamiento ha sido utilísimo), a Javier López Alós (por su valiosísima lectura, así como también por su cabalidad y generosidad), y a Francisco Castilla. Y ya dejando para el final, pero no por ser en absoluto menos importantes, enuncio ahora mi hondo agradecimiento a los profesores y personal administrativo del 'Doctorado en Humanidades - Línea Filosofía Moral y Política' de la Universidad Autónoma Metropolitana - Unidad Iztapalapa, que, en efecto, ha sido una «Casa abierta». Gracias por la acogida, la oportunidad y la ayuda. Primeramente, dar unas gracias enormes a Jörg Alejando Tellkamp, mi Asesor de tesis, que con paciencia y tino me ayudó a acotarla y encaminarla, así como a ser más precisa, pero que a la vez no me cortó las alas. Quiero también mostrar mi inmensa gratitud a María Pía Lara por su apoyo siempre y por su lucidez. Asimismo, les doy las gracias por su constante disponibilidad a ayudar y por su calidez como coordinadores a Gustavo Leyva y Jesús Rodríguez Zepeda, y a sus asistentes. Otro muy sentido agradecimiento es para Teresa Santiago y Francisco Quijano, lectores y sinodales de mi tesis, quienes realizaron una lectura muy seria, inteligente, detallada y dadivosa de ésta, lo cual me ha reconfortado mucho, sobre todo por ver que mi trabajo puede suscitar sugerentes reflexiones e intercambio intelectual. Muchas gracias también a los profesores $\mathrm{M}^{\mathrm{a}}$ José Rodilla y Álvaro Ruiz Abreu, que han sido, y son un poco, mis papás mexicanos. Deseo también resaltar los estupendos y brillantes colegas que he tenido en el Doctorado: Ana Sofía Cabello, Octavio Martínez Michel, Liliana Arcos, José Lira, Stephie Graf, José León, Marcos Alegría, etc., gracias, compañeros.

Ojalá ese doctorado le sea útil a otros, pues el conocimiento no puede sino ser libre y compartido, y que me permita materializar mi vocación docente, porque sigo creyendo firmemente en la capacidad de la universidad — sobre todo la pública- como espacio de generación de pensamiento crítico, equidad y justicia social, y de esperanzador vitalismo. 


\section{INTRODUCCIÓN}

El trabajo que aquí comienza se aborda como un ejercicio de historia de la filosofía política, de historia intelectual y de genealogía crítica de la modernidad hispánica. Versa sobre el pensamiento político castellano del siglo $\mathrm{XV}$, concretamente acerca de una de sus principales manifestaciones, la cual hemos denominado pensamiento político converso. Asimismo, cuestiona la aplicabilidad para el caso castellano de una serie de categorías conceptuales propias de la historia de la filosofía política - principalmente la noción de humanismo cívico - con las que se ha elaborado la narración académica imperante de cómo fue de la génesis de la modernidad política y que han implicado la exclusión del ámbito hispánico del relato de ésta. Mostraremos las principales características y particularidades de dicho pensamiento político converso. Sostenemos que éste, desarrollado fundamentalmente por intelectuales judeoconversos, articuló valores republicanos y elementos teológicos en pro de una racionalidad política inclusiva que posibilitase la participación cívica y que permitiese la configuración de una communitas cristiana que deviniera también comunidad política.

Tomará esta investigación como texto de estudio de caso y como soporte textual que apoya y demuestra las características identificadas como intrínsecas de este pensamiento político converso que nos ocupa - al ser uno de sus epítomes - el Defensorium unitatis christianae de Alonso de Cartagena, escrito en 1449 y detonado por las políticas de exclusión hacia los conversos. Proponemos una lectura en clave republicana de dicha obra, cuyo principal rasgo de interés para esta tesis es la politización que plantea de elementos teológicos. Además de su apuesta por el control jurídico contra la arbitrariedad y el uso coercitivo del poder, control jurídico éste muy influido por el constitucionalismo, movimiento, sin duda, también permeado de valores republicanos. Sostenemos que la teología política de Cartagena está centrada (asimismo, en un pliegue republicano) en la idea de un pueblo que es potencialmente ciudadanía, y que deviene ciudadanía a través, precisamente, de una instrumentalización de elementos religiosos — principalmente el bautismo o la universalidad de la gracia - los cuales se tornan herramientas de dignificación cívica, de otorgamiento y restitución de la virtud, de protección 
jurídica y de acceso a la participación en el vivere civile. La teleología cristiana de la salvación y la teleología ética republicana de la vita activa en la vida cívica se engarzan. Es mediante la religión, mediante su noción de república cristiana, como Cartagena quiere implementar una ratio política de la inclusión y la cohesión (concepto éste de unidad ligado también con el organicismo político y teológico), esto es: su defensa de la unión de los cristianos, como expone el título del tratado que nos ocupa, es también defensa de la conformación de base comunitaria republicana, y de comunidad política solidaria y participativa frente a una racionalidad de la exclusión y la dominación.

Pretendemos visibilizar tanto este pensamiento político converso como el Defensorium unitatis christianae con el fin de resaltar su importancia en la conformación de un proyecto político y social para la implementación de la modernidad política en el ámbito hispánico, proyecto que, pese a no resultar plenamente exitoso como proyecto político, estimamos que generó una profunda impronta en la historia intelectual hispánica.

\section{Detección de problemáticas: la invisibilización e incomprensión del pensamiento político castellano en los albores de la Modernidad.}

Como problemática de fondo que cataliza esta tesis se nos presenta el minimizado papel que se le ha otorgado al pensamiento hispano e hispánico en la historia de la filosofía, falta de atención que es todavía más flagrante en la historia del pensamiento político. Como problemática general, y que es consecuencia de la anterior, aparece el hecho de la poca visibilidad que se le ha dado a la filosofía política hispana en la historia de la conformación de la modernidad política. Éste es un vacío que, entendemos, ha de llenarse, y por ello una de nuestras contribuciones aquí será el analizar el pensamiento político castellano de siglo $\mathrm{XV}$, y hacerlo en base a las corrientes políticas, intelectuales y espirituales de su ámbito europeo, pero señalando también sus especificidades.

El que este trabajo contemple que en el ámbito ibérico existió un pensamiento político de corte republicano es ya un aporte crítico, e implica ya una suerte de necesario ejercicio de genealogía crítica de la modernidad política, pues normalmente las narrativas académicas 
hegemónicas han excluido al ámbito hispánico de esta tradición republicana (problemática concreta detectada asimismo). Y el que tenga en cuenta esta investigación, como veremos, que este pensamiento republicano castellano se articuló con elementos religiosos y con elementos inherentemente ibéricos, y que se tradujo en la demanda de unas prácticas políticas de corte parlamentarista y constitucionalista propias de una monarquía mixta, implica ya una muestra de su especificidad.

En la historia de la filosofía política y en la historia intelectual imperantes, no se ha contemplado la existencia de republicanismo al hablar de la modernidad temprana en el ámbito hispánico, y se ha planteado la consolidación de la modernidad política en este espacio como defectiva, esto es, como una anomalía de lo que supuestamente supone la modernidad política, que se ha vinculado sobre todo al espacio del renacimiento italiano y luego al liberalismo atlántico anglosajón. El hecho de que en Castilla el pensamiento republicano se imbricase con una cosmovisión escatológica, con la escolástica y con una defensa de la monarquía (providencialista y organicista, pero no teocrática) — características éstas que lo diferencian de otros contextos como el republicanismo florentino, que ha sido tomado por la historia de la filosofía política como paradigmático-, no implica que en Castilla, y posteriormente en todo el espectro del llamado Mundo hispánico, no aconteciese la recuperación de los valores republicanos propia de los siglos XV y XVI.

Otra problemática concreta que necesita ser aclarada es la habitual visión restrictiva y distorsionada que se ha tenido de cómo funcionó de facto la Monarquía Hispánica, visión que no repara ni ahonda en los debates que en efecto ya se dieron en el ámbito hispano e hispánico durante el siglo XV y principios del XVI acerca de la idea del origen y la legitimidad de la autoridad y de la conveniencia de un gobierno mixto como medida de control contra el uso arbitrario de ésta. Consideramos que todo esto viene de una errónea asimilación de lo que fue el pensamiento republicano en el siglo $\mathrm{XV}$, interpretación anacrónica y restrictiva que ha cooptado el relato de en lo que consistió entonces el pensamiento republicano y que ha forjado un patrón único de éste, patrón que no se corresponde con el Mundo Hispánico, por lo que a éste se lo ha excluido. El equívoco viene también por contemplar el mundo hispánico con ciertos prejuicios, y por no considerar que en él, en los albores de la modernidad, convivieron diversos lenguajes 
políticos y hubo también espacios de controversia — que no fue todo pensamiento oficial—, así como por no asumir que el pensamiento republicano se implementó de diversas formas en los distintos ámbitos geográficos. Dicha limitada interpretación no tiene en cuenta que en el caso hispano, e hispánico posteriormente, el pensamiento republicano era compatible - es más, se retroalimentaba - con cuestiones como su articulación con elementos cristianos (así la universalidad de la gracia y la revelación, la idea de cuerpo místico y la de comunidad, o la alineación de teleología cívica y teleología de la salvación), la existencia de una filosofía de la historia escatológica, el apoyo a la monarquía (bajo enfoques que defendían la transferencia de autoridad del rey a la comunidad política, el modelo de gobierno mixto o el organicismo), la escolástica, o la presencia del factor semítico.

Asimismo, otra problemática detectada que detonó este trabajo fue la falta de estudios acerca del pensamiento político de Alonso de Cartagena, una figura que a pesar de haber sido de una fundamental importancia durante el siglo XV - tanto castellano como europeo - ha caído en cierto olvido, y que la mayoría de veces que se ha estudiado ha sido desde la filología. Este autor que nos ocupa encarna las características de lo que hemos definido como pensamiento político converso, y representa además una sugerente muestra de transición epocal que conjuga elementos propiamente renacentistas con la mejor escolástica medieval (demostrando que ambas herencias pudieron convivir fructíferamente). Aglutina en su persona rasgos de diversas tradiciones intelectuales y culturales.

Nos interesa detenernos en su obra Defensorium unitatis christianae porque en ella cristaliza uno de los aspectos que entendemos como más destacados de la forma particular en la que sostenemos se desarrolla y se refunda el pensamiento republicano en Castilla: la hibridación entre elementos republicanos y elementos cristianos. Esto es, la traductibilidad cívica de nociones como la universalidad de la gracia y la revelación, la instrumentalización del bautismo como herramienta garante del acceso igualitario a la ciudadanía y de la unidad - y por tanto como posibilitador de la participación y de la paz social en libertad — la adaptación política de la idea comunidad cristiana en busca de la consolidación de una base comunitaria que devenga comunidad política, o la alineación entre teleología de la virtud cívica y teleología de la salvación; constituyendo todo ello una ratio política inclusiva y promoviendo un proyecto de 
convivencia para Castilla que eliminase la exclusión por esencialismos de origen e impidiese el auge de leyes segregacionistas.

La justificación de esta tesis doctoral emerge del interés de ésta por hacerse cargo de todas estas problemáticas detectadas.

\section{Cómo afronta esta tesis dichas problemáticas Preguntas de investigación, objetivos y apunte metodológico.}

Por todo lo anterior, el planteamiento de esta investigación ha tenido la intención de responder satisfactoriamente preguntas como las siguientes: ¿De dónde emanan ciertas particularidades de la modernidad hispánica, más allá del relato habitual que han hecho la historia intelectual y la historia de la filosofía política y qué explican tales particularidades? ¿Han tenido en cuenta la historia de la filosofía política y la historia intelectual — en su relato de la implementación de la modernidad política - el caso castellano? ¿Cuáles son las características del pensamiento político castellano del siglo XV y quiénes los intelectuales que lo promovieron? ¿Se ha vinculado suficientemente la historia de la filosofía política hispánica con el republicanismo, y se han reivindicado sus manifestaciones propias? ¿Qué contexto determinó las condiciones de posibilidad de que el pensamiento republicano se desarrollase en el caso castellano, y de que lo hiciese como lo hizo: de dónde y por qué surge, de qué tradiciones intelectuales se nutre, qué problemáticas históricas quería resolver y con qué estrategias? ¿Cómo influyó cierto pensamiento político del siglo XV castellano en la implementación de la modernidad política y en la racionalidad política y teológica en el llamado Mundo hispánico en la modernidad temprana?

Con el fin de satisfacer esta preguntas, la presente tesis se perfila en torno a los siguientes objetivos:

- Visibilizar el pensamiento político castellano del siglo XV y hacer notar su relevancia. Concretamente visibilizar y describir una de sus principales manifestaciones, la que 
hemos denominado pensamiento político converso (que también podríamos denominar pensamiento republicano converso).

- Visibilizar dicho pensamiento político converso en el contexto de la teoría política de su entorno europeo.

- Visibilizarlo frente a la versión dominante en el relato académico del advenimiento de la modernidad política, realizando así un ejercicio de genealogía crítica de la modernidad política hispánica.

- Revisar críticamente y problematizar ciertas categorías académicas imperantes empleadas por historia de la filosofía política al tratar la génesis de la modernidad política, las cuales, tal y como están descritas, no operan para el caso castellano. Categorías conceptuales tales como humanismo cívico.

- Analizar las especificidades diferenciadoras de dicho pensamiento político castellano del XV y del origen político, intelectual, social y teológico de las mismas, esto es, abordar el contexto intelectual, social y teológico que deviene su condición de posibilidad y cuyas problemáticas quiere aplacar dicho pensamiento político converso.

- Describir y reivindicar el particular pensamiento republicano (compatible y articulado con la teología, la escolástica y la monarquía) que se da en el ámbito castellano. Y enriquecer y ampliar con ello la historia del republicanismo.

- Poner en valor la impronta intelectual y teológica de dicho pensamiento político converso castellano, y, asimismo, hacer notar las consecuencias que la marginación de su proyecto político tuvo en el llamado Mundo hispánico

- Recuperar la figura de Alonso de Cartagena y la importancia de su pensamiento teológico-político como epítome de este pensamiento político converso (para ello se 
propone una lectura original de su Defensorium unitatis christianae, 1449, en clave republicana)

- Hacer notar la valía del proyecto político que entraña el Defensorium y su promoción de una ratio política de la inclusión, la participación y la convivencia.

- Sugerir la comprensión del Defensorium como elemento de mediación diacrónica útil para reflexionar acerca de la necesidad de crear un espacio político integrador de diferencias, y que pueda ser de ayuda al abordar debates actuales como el de las lógicas de la exclusión por parte de muchos estados o el de la postsecularidad.

En cuanto a la metodología con la que se aborda esta tesis doctoral, lo primero que hemos de resaltar es que concebimos ésta como un ejercicio de historia de la filosofía política, de historia intelectual, de genealogía crítica de la modernidad hispánica y de reflexión acerca de la relación entre teológica y política. Nos detendremos primeramente en el análisis de ciertos conceptos y categorías académicas tales como republicanismo o humanismo cívico, teniendo para ello presentes como telón de fondo los presupuestos la historia conceptual y de la reelaboración de ésta por el conocido como 'Grupo de la Universidad de Padua', así como considerando los aportes de cariz analítico e historicista hechos por la 'Escuela de Cambridge' en el desarrollo más reciente de la llamada nueva historia intelectual, y entendiendo las ideas como algo existente, frente a un método positivista ${ }^{1}$. No haremos, sin embargo, esta revisión de ciertas categorías con una vocación de elucubración teórica, sino por el hecho de que hay ciertos escollos y equívocos conceptuales que han sido definitorios en la mala comprensión que, a

\footnotetext{
${ }^{1}$ Al hablar del 'Grupo de la Universidad de Padua' o 'Escuela de Padua', nos referimos a una línea de interpretación y de investigación de la historia de los conceptos, seguida sobre todo por el "Grupo de investigación de los conceptos políticos modernos» que, desde finales de los años 70 del pasado siglo XX, dirige Giuseppe Duso en el Instituto de Filosofía de la Universidad de Padua (véase más adelante para mayor detalle el Capítulo 1).

Grosso modo podríamos decir que se conoce como 'Escuela de Cambridge' a un grupo de estudiosos que a mediados de los años 60 y en el entorno de la Universidad de Cambridge, acometieron una revisión metodológica en la forma de afrontar la historia del pensamiento político. Promovieron el estudiar los textos de cada periodo bajo un enfoque contextualista, esto es, abordar las ideas políticas emanadas de los textos teniendo en cuenta los lenguajes políticos propios de cada momento y del autor, los debates y las situaciones históricas que los detonaron, y dándole al estudio de las fuentes un calado más analítico, de análisis del discurso y cercano a la filosofía. Como figuras emblemáticas, podríamos encuadrar dentro de esta 'Escuela de Cambridge' a autores como J.G.A Pocock, Quentin Skinner.
} 
nuestro entender, se ha dado por parte de la academia hegemónica en la interpretación de la historia de la filosofía política en la temprana modernidad el ámbito hispánico. Es decir, este repaso crítico es necesario para poder comprender esta tesis en su conjunto, pues, precisamente, la revisión crítica sobre la adaptabilidad de ciertas categorías de la historiografía política empleadas para trazar el relato sobre la implementación de la modernidad política europea y sobre la historia del republicanismo, nos va a permitir sustentar las especificidades de nuestro caso esto es, las intersecciones y las fugas del caso castellano con respecto a su contexto europeo. Y esto va a contribuir a entender el porqué de la marginación y el silenciamiento que el pensamiento político castellano del XV ha sufrido en la narración académica imperante, reparar en lo cual es vital para poder realizar un ejercicio de genealogía crítica de la modernidad política y una más completa, rica y poliédrica historia del republicanismo. Considerando el momento temporal y espacial que abordamos, y para poder referirnos de un modo inteligible y apropiado a aquello a lo que concretamente remitimos (esto es, el pensamiento político y la teología política propios de los intelectuales judeoconversos del cuatrocientos castellano, y a la figura de Alonso de Cartagena como epítome de éstos) es preciso que nos detengamos en la cuestión de qué herramientas tenemos para nombrarlo y analizarlo.

Partimos de una epistemología situada, en el sentido de entender que las variables contextuales - tanto intelectuales como espirituales, y sociales e históricas - que se dan en Castilla son determinantes, deviniendo catalizadoras que condicionan que este pensamiento político converso y su republicanismo sean de una manera y no de otra. Teniendo en cuenta lo local, esto es, un ámbito geográfico y cultural propio, es como podrán detectarse las especificidades en la implementación de las grandes corrientes de pensamiento en un contexto determinado, y como podrá actuarse críticamente frente a relatos filosóficos e historiográficos dominantes. Además, consideramos que la matriz cultural semítica ibérica, y el componente experiencial de la propia vivencia de exclusión sufrida por los pensadores conversos influyen en los rasgos de lo que denominaremos como pensamiento político converso. Sin embargo, quepa aclarar que, pese a esto, no deseamos reproducir el discurso dominante de interpretar el caso ibérico como una anomalía periférica a lo que sucede en el contexto de la filosofía política europea del siglo XV, puesto que no lo es, y participa con paridad en los debates intelectuales. 
Por ello realizaremos esta deixis epistemológica sin aislar este contexto específico de su entorno más global, esto es, su ámbito europeo.

Queremos señalar que el proceso de este trabajo será dialéctico: las conclusiones que extraigamos de reflexionar sobre el contexto que catalizó a este pensamiento político converso y lo que definamos como sus rasgos intrínsecos, nos permitirá una comprensión más profunda de Cartagena y de cómo se trenzan en su pensamiento los rasgos republicanos, y, a su vez, estudiar a Cartagena nos ayudará a poder sistematizar las características de dicho pensamiento político converso.

Otro rasgo metodológico que queremos apuntar es la importancia que le daremos en este trabajo al componente textual de una fuente de la época como necesario soporte para demostrar nuestras inferencias. Estimamos que el tener en cuenta los textos, los espacios de debate y los lenguajes políticos propios del momento de estudio que se aborda, ayuda a evitar anacronismos y conclusiones sesgadas, demasiado abstractas o infundadas.

En relación con esta cuestión del soporte textual, quepa aclarar que seguiremos en este trabajo las ediciones del Defensorium unitatis chistianae llevadas a cabo por Manuel Alonso (que mantiene el latín original) y Guillermo Verdín-Díaz (traducida al castellano) ${ }^{2}$. Ambas ediciones están basadas en dos copias manuscritas de la obra (derivadas a su vez las dos del mismo original). Dichas copias son la de la Biblioteca Nacional de Madrid (mss. 442), del propio siglo XV, y la de la Biblioteca de la Universidad de Salamanca (mss. 2070) —en otro tiempo estuvo en la Biblioteca de Palacio, donde estaba catalogado como mss. 1642 - ya del siglo XVI.

Pese a no ser expertos en teología o filosofía de las religiones, hemos procurado ser precisos en el uso de nociones de la teología cristiana y hacer un esfuerzo de comprensión de las mismas sin prejuicios, ya que sostenemos, como hemos venido apuntando, que la mayor particularidad y aporte de Defensorium es precisamente su articulación de elementos teológicos y republicanos.

\footnotetext{
${ }^{2}$ Alonso (1943), Verdín-Díaz (1993).
} 


\section{Contribución de este trabajo para hacerse cargo de tales problemáticas: puesta en valor del pensamiento político converso y recuperación de la figura de Alonso de Cartagena.}

A modo de anticipación de los aportes logrados con este trabajo - punto que, junto con su pertinencia, abordaremos en las conclusiones del mismo - señalar aquí someramente que la contribución original más reseñable de la tesis defendida a continuación consiste en su apuesta por visibilizar y poner en valor dicho pensamiento político castellano propio del $\mathrm{XV}$, por ver sus condiciones de posibilidad, sus rasgos específicos, sus influencias, su forma de abordar ciertas problemáticas sociales, sus lenguajes políticos, sus aportes a la filosofía política del momento, su teología política o su impronta posterior en hitos tan importantes como la Segunda Escolástica, la Revolución Comunera, o la tradición republicana en Hispanoamérica. En definitiva, en este trabajo realizaremos la contribución de acotar, describir y denominar la que consideramos la más importante manifestación del pensamiento político del siglo XV en Castilla: el pensamiento político converso. $\mathrm{Y}$, asimismo, de demostrar la existencia en éste de elementos provenientes de la tradición republicana, tanto clásica como medieval, y también propiamente renacentista.

Pero no sólo esto, queremos demostrar que, en el caso castellano, esta recuperación del republicanismo va intrínsecamente ligada a lo teológico y a la circunstancia conversa. Y hacer notar que es precisamente su engarce con el cristianismo lo que lo hace particular y un sugerente objeto de estudio, probar que no lo lastra, sino que lo hace específico, ni más, ni menos. El conocimiento de dicho pensamiento político converso permitirá abrir una veta de estudio que se centre en la impronta política, teológica, intelectual y jurídica que dicho pensamiento supuso en la conformación de la modernidad política en el Mundo hispánico y del pensamiento republicano propio de éste.

Asimismo, como aporte original, hemos llevado a cabo también una crítica a la extrapolación que se hecho de la categoría conceptual de humanismo cívico (categoría académica acuñada inicialmente para el caso del Quattrocento político florentino). Ésta, al aplicarse como baremo imperante de la presencia o no de pensamiento republicano y de modernidad política, ha provocado que, sistemáticamente, en la historia de la filosofía política se lea al ámbito hispánico como huérfano de ambos, cuando el verdadero problema es que tal y como se ha definido tal 
etiqueta no es aplicable para dicho caso, lo cual, sin embargo, no implica en absoluto, a nuestro modo de ver, el que no se desplegase pensamiento republicano en Castilla. Lo que queremos reivindicar es justamente que sí se dio, pero con una serie de particularidades que no le restan valía, sino que, reiteremos, lo hacen específico y que, incluso, lo enriquecen.

Hemos pretendido también como contribución trasversal en este trabajo desenredar ciertos equívocos e incomprensiones. Por ejemplo, hemos querido librar al lenguaje político y epistémico que es la tradición escolástica o a la noción teología política de la habitual carga negativa que las juzga a priori como retrógradas e incompatibles con cualquier atisbo de republicanismo, aseveraciones éstas cuya falta de sustento para el caso castellano hemos intentado demostrar (como explicaremos, no pensamos que una cosmovisión secular es condición necesaria para que acontezca el pensamiento republicano, además, pretender hablar de secularismo en el siglo XV implica un tremendo anacronismo). Lo mismo sucede con la infundada idea de que pensamiento republicano y monarquía son excluyentes, afirmación que omite de entrada toda la tradición de reflexión y práctica política del modelo de gobierno mixto.

Otra contribución que pretende hacer esta tesis es poner el foco sobre el pensamiento de Alonso de Cartagena, recuperar su figura, promover los trabajos acerca de su filosofía política y reivindicar una lectura más profunda y moderna de sus textos (a veces mal entendidos o minusvalorados hoy en día por su formato escolástico o por su temática de obra de circunstancia dada la faceta de Cartagena como hombre de Estado). Salvo contadas y valiosas excepciones, entre las que cabe destacar el trabajo de Luis Fernández Gallardo, José Luis Villacañas, Fernando Miguel Pérez Herranz, Guillermo Verdín-Díaz, Francisco Castilla, Enver Torregroza, María Morrás, Rafael Herrera, Javier Cárdenas o Stefania Pastore, resulta sorprendente la escasez hasta la fecha de investigaciones sobre el pensamiento político de Alonso de Cartagena, teniendo en cuenta el peso que tuvo dentro de la intelectualidad europea del siglo XV (desde su vital papel en el Concilio de Basilea, hasta su interlocución con autores como Leonardo Bruni o Pier Candido Decembrio) y su impronta en la Segunde Escolástica ${ }^{3}$. La mayoría de los estudios

\footnotetext{
${ }^{3}$ Fernández Gallardo (2002) (2007), José Luis Villacañas (2017) (2014) (2012) (2012 b) (2005) (2005c) (2004), Fernando Miguel Pérez Herranz, (2016), Guillermo Verdín-Díaz (1993), Francisco Castilla (2010) (2011) (2012), Enver Torregroza (2008) (2010) (2011), María Morrás (2002a) (2002b) (1996) (1995) (1991), Rafael Herrera, (2016), Javier Cárdenas (2011) o Stefania Pastore (2004).
} 
sobre él se centran en su dimensión como traductor de Séneca y Cicerón - lo cual ya es una pista de que hay una sugerente veta política y republicana en él-o en su labor como rigorista católico. Vamos en el presente trabajo a incidir en la faz política del Defensorium unitatis christianae de Cartagena, a tratar de demostrar la dimensión de esta obra como tratado que elabora toda una racionalidad política y teológica. Reflexionaremos también acerca de las consecuencias que tuvo la marginación de su proyecto teológico-político y sobre la gran impronta intelectual que, sostenemos, paralelamente, su figura generó.

\section{Diseño de las tesis}

La presenta tesis consta de dos partes, cada una de dos capítulos. La primera parte, de corte más teórico y conceptual, titulada «Pensamiento político converso en la Castilla del XV», consiste, primeramente, en una revisión crítica (a modo de estado del arte) acerca de cómo desde la historia de la filosofía política se ha abordado la implementación de la modernidad política y la historia del republicanismo, así como de las herramientas conceptuales que se han empleado para ello. A continuación se reflexionará acerca de la aplicabilidad de lo anterior para el caso castellano, y, ante la demostración de la falta de ajuste de éste en las categoría comúnmente utilizadas, se propondrá una denominación específica: pensamiento político converso. Posteriormente, se realizará una identificación de las características propias del que denominamos como pensamiento político converso, así como un análisis de sus causas teniendo en cuenta el contexto intelectual castellano del siglo XV.

La segunda parte, titulada «Estudio de caso: el Defensorium unitatis christianae de Alonso de Cartagena», consiste en la sustentación textual, a través de una fuente que resultó un texto cumbre en el contexto que nos ocupa, de las características que en la primera parte habíamos identificado como intrínsecas y diferenciadoras de dicho pensamiento político converso dotando así al trabajo de una estructura circular. Se pretende que haya una coherencia interna entre las dos partes de la tesis, y que éstas estén en todo momento interrelacionadas (para lo que se harán constantes referencias intertextuales), ya que la segunda parte se entiende como un soporte textual que pruebe lo planteado en la primera. Encarar Defensorium unitatis christianae como texto clave para entender la teología política propia del pensamiento político 
converso que nos ocupa, implica entender el núcleo mismo de éste. En esta segunda parte centrada en Alonso de Cartagena, se recupera el pensamiento político - sobre todo su dimensión articuladora de pensamiento republicano y teología - de dicho autor y se reivindica su importancia. Asimismo, se pone en valor la racionalidad política inclusiva que puede destilarse del Defensorium.

Conforman el cuerpo de este trabajo cuatro capítulos, dos en cada parte. Cada uno los capítulos tendrá a su vez unas pequeñas introducción y conclusión que subrayen su contenido y aportes más destacados.

El capítulo primero, titulado «Acotación e identificación de problemáticas en torno a las categorías de republicanismo, humanismo cívico y teología política para nuestro estudio de caso. Propuesta de denominación para el mismo: pensamiento político converso», se presentará como un capítulo de cariz metodológico, de posicionamiento conceptual y de estado del arte, y consistirá en la presentación y crítica de las categorías humanismo, humanismo cívico, humanismo político, republicanismo y teología política. Trataremos de acotar qué entendemos en este trabajo por republicanismo, y qué uso vamos a darle al término. Haremos un apunte también respecto al propio termino humanismo, categoría bastante difusa. Expondremos, asimismo, nuestra crítica y la demostración de la no aplicabilidad para el caso hispano de una proposición de tanto peso como es la tesis de Hans Baron al acuñar el concepto humanismo cívico, o nuestra discrepancia con ciertos presupuestos sobre historia del republicanismo (sobre todo los centrados en el llamado republicanismo atlántico, teniendo en cuenta para ello principalmente el trabajo de J. G. A. Pocock y algunos de los autores relacionados con la llamada 'Escuela de Cambridge') ${ }^{4}$.

A modo de estado del arte y antes de presentar nuestra propia crítica, realizaremos un repaso de las críticas más importantes llevadas a cabo en las últimas décadas en torno esta categoría de humanismo cívico (por ejemplo las de James Hankins, Athanasios Moulakis, Guido Cappelli, Juan Varela-Portas, John Elliott, Quentin Skinner, Lucia Gualdo, Thomas Pangle, Daniel Siegel o Christopher Celenza); todo inscrito dentro del actual creciente interés en los

\footnotetext{
${ }^{4}$ Baron (1993) (1955a) (1955b), Pocock (1988) (2002).
} 
estudios sobre republicanismo ${ }^{5}$.

Ya en nuestra propia crítica, más que rechazar per se la categoría de humanismo cívico, nuestra disconformidad radicará en la extrapolación que de esta categoría se ha hecho, y demandaremos la consideración del tipo de pensamiento republicano que acontece en el ámbito hispánico durante los siglos XV y XVI. Detectaremos problemáticas en el uso en la historia de la filosofía política - y en la historia del republicanismo, concretamente - de dicha categoría de humanismo cívico tales como: anacronismo, concepción unívoca del pensamiento político del momento, extrapolación del humanismo florentino uniformando así normativamente lo que ha de implicar la Modernidad política, o empleo de este concepto para hacer una narración legitimadora del republicanismo atlántico (que se presenta como único). Teniendo en cuenta todo lo anterior, en el desarrollo de nuestro capítulo justificaremos por qué la imperante categoría académica humanismo cívico, asumida como la corriente que abarca el pensamiento político republicano de los siglos XV y XVI, no opera para el caso castellano. Y no lo hace básicamente por tres razones: porque en Castilla el republicanismo es de corte escolástico, porque convive con un claro apoyo a la monarquía y porque su filosofía de la historia es escatológica, de hecho el rasgo más característico a nuestro entender del republicanismo castellano es su articulación con elementos de la teología cristiana. Explicaremos, por consiguiente, por qué proponemos entonces una denominación alternativa para nuestro objeto de estudio, ésta es: pensamiento político converso.

Analizaremos en el segundo capítulo el contexto intelectual del siglo XV en Castilla. Esto es, abordaremos las condiciones de posibilidad de este pensamiento político converso: las causas que lo posibilitaron y determinaron, por qué surgió, qué problemáticas históricas trató de resolver, a qué tendencias intelectuales y espirituales se vinculó, en qué espacios de conflicto intervino, qué estrategias empleó, su postura frente régimen político circundante, etc. Nos detendremos en describir este contexto filosófico, religioso y socio-político que catalizó tal pensamiento político converso con el fin justificar en base a él sus características y particularidades diferenciadoras. Elaboraremos la reconstrucción de este contexto intelectual en

\footnotetext{
${ }^{5}$ Hankins (1994) (1995) (1998) (2010), Moulakis (2011), Cappelli (2006) (2009) (2011) (2014), Elliott (2005) (2006), Skinner (1985) (1999) (2002) (2004) (2010), Gualdo (2005), Pangle (1988), Siegel (1966) o Celenza (2004).
} 
torno a una serie de ejes o variables que, según nuestro criterio, son los más significativos y los que más influyen en la conformación del pensamiento político converso. Es decir, son las aristas que pensamos más determinan al pensamiento político converso y que nos permiten comprender mejor en qué consiste éste y por qué tiene las característica específicas y diferenciadoras que tiene. Los ejes en torno a los cuales pivotará el retrato del contexto intelectual que traza este capítulo son los siguientes: 1) La cuestión conversa. 2) La función social del letrado. 3) "La Primera Escuela de Salamanca". Escolástica y pensamiento político. 4) Proto-reforma, paulinismo, organicismo teológico y conciliarismo en Castilla. 5) Acerca de la noción de monarquía. 6) El proyecto de un modelo de gobierno mixto. Las Cortes en Castilla durante el siglo XV: de las Cortes de Briviesca a la Junta de Ávila.

Transversalmente, durante este segundo capítulo, iremos desvelando los rasgos más destacados de lo que hemos acuñado como pensamiento político converso (determinado por los ejes arriba indicados), así: su vínculo inherente con la circunstancia y la tradición intelectual conversa; su raigambre escolástica; su articulación entre elementos religiosos y republicanos (herederos del tomismo y aristotelismo cristiano, el universalismo teológico, el paulinismo, el organicismo político y místico o el profetismo hebreo); su idea de monarquía providencialista, pero no teocrática en cuanto a la cuestión de los orígenes y límites de la autoridad; su vocación de una monarquía mixta (modelo transido de conciliarismo, consitucionalismo y protoparlamentarismo); o la vocación de una racionalidad política inclusiva dados los problemas de convivencia existentes en la Castilla del cuatrocientos.

Daremos paso con el capítulo tercero a la segunda parte de esta tesis, esto es, al estudio de caso. Consistirá tal capítulo en una introducción al autor que nos ocupa, Alonso de Cartagena, a su producción textual y a su pensamiento político (acerca concretamente de su teología política versará el capítulo cuarto). Lo presentaremos como un teólogo y hombre de Estado, y como un personaje de transición epocal y que hibrida diversas tradiciones intelectuales (tomismo, aristotelismo, influencia ciceroniana, conciliarismo, tradición jurídica castellana, racionalismo árabo-semítico, profetismo hebreo, o goticismo monárquico, entre otras). Asimismo, expondremos los debates - sobre todo desde la filología, por ser casi los únicos existentes y dada la labor de Cartagena como traductor- en torno a su figura. 
Nos detendremos fundamentalmente en este capítulo en su enfoque sobre cuestiones como la monarquía, el origen y los límites de la potestas y la idea servicio público. El aporte principal que pretendemos hacer es la recuperación y la invitación a dotar de nueva mirada a Cartagena, quien, pese a haber tenido una importancia crucial en el siglo $\mathrm{XV}$, ha sido descuidado por la historia intelectual y la historia de la filosofía política, que parecen haber reproducido el abandono oficial que de su pensamiento se hizo en el siglo XVI (aunque, como veremos, su herencia pervivió en el llamado pensamiento hispánico).

El cuarto capítulo consistirá en un análisis textual del Defensorium unitatis christianae (1449), el cual consideramos texto cumbre de la teología política de Alonso de Cartagena y epítome del pensamiento político converso. Primeramente se presentará dicha obra y se hará un apunte filológico y sobre su transmisión textual, un resumen de su contenido y un análisis del las fuentes que en este escrito, de formato escolástico, se toman como autoridades y en base a las cuales se estructura la argumentación. Asimismo, se hará una explicación del origen de este texto que nos ocupa, haciendo notar su dimensión como "obra de circunstancia" que denuncia el pogromo antijudío de Toledo de 1449 y la activación subsiguiente de los estatutos de limpieza de sangre, pero que, sin embargo, trascendió ese fin y acabó suponiendo no sólo una crítica jurídica de las políticas de exclusión en base a esencialismos de origen, sino también un tratado de convivencia, de revisión teológica y de búsqueda de conformación de comunidad política. Todo ello cimentado en la traductibilidad entre pensamiento republicano y teología, y en la voluntad de aplicabilidad de la universalidad de la gracia a conquistas civiles. Argumentaremos, asimismo, dónde entendemos que reside el valor de dicho tratado.

Posteriormente abordaremos el análisis de la teología política del Defensorium, basándonos en diversas referencias textuales del mismo. Dicho análisis será configurado y sustentado en torno a los siguiente ejes: 1) 'Revisión teológico-histórica de la relación entre judaísmo y cristianismo y filosofía de la de historia en Cartagena. La construcción de pueblo como comunidad política y como comunidad religiosa', 2) 'Uso de la metáfora organicista como argumento para la unión, solidaridad y equidad en la república cristiana', 3) 'Instrumentalización política de elementos teológicos para conformar una ratio de la inclusión y de acceso a la 
ciudadanía. El bautismo como posibilitador de acceso a la participación cívica', 4) 'Reacción ante el uso arbitrario de la autoridad. Desactivación jurídica de los estatutos de limpieza de sangre. Deslegitimación de las políticas de segregación'. Ya al final del capítulo llevaremos a cabo una breve reflexión sobre la impronta y marginación del pensamiento de Cartagena.

Daremos así paso al cierre de esta tesis doctoral, conformado por las conclusiones, en las cuales mostraremos las contribuciones que con ella hemos querido realizar y las sugerentes vetas para futuras reflexiones e investigaciones que, a nuestro entender, ha abierto la que ahora presentamos. 


\section{CAPÍTULO 1: Acotación e identificación de problemáticas en torno a las categorías de republicanismo, humanismo cívico y teología política para nuestro estudio de caso. Propuesta de denominación para el mismo: pensamiento político converso.}

\section{Introducción al Capítulo I}

Tal y como explicamos con detalle en la introducción general de esta tesis, como uno de los objetivos generales de la misma se presenta el visibilizar el pensamiento político castellano del siglo XV y hacer notar su relevancia y la impronta política, teológica, intelectual y jurídica que dicho pensamiento supuso en la conformación de la modernidad política en el Mundo hispánico. $\mathrm{Y}$, concretamente, visibilizar una de las principales manifestaciones de este pensamiento político castellano del cuatrocientos, la que hemos denominado pensamiento político converso - analizar sus causas, sus particularidades, sus andamiajes teóricos, sus lenguajes políticos, sus prácticas sociales, etc.- - Y visibilizarla, además, en su contexto europeo y poniéndola en valor frente a la versión imperante en la narración académica de la historia de la filosofía política y la historia intelectual acerca de cómo fue advenimiento de la modernidad política. Narración que grosso modo no reconoce la forma específica en que se implementaron elementos propios del periodo — como la recuperación de valores republicanos—en el ámbito ibérico, resultando por ello una narración unívoca que limita y pretende uniformar en qué consistió el siglo XV para la filosofía política europea.

Pues bien, en la tarea de lograr lo arriba indicado, y con el fin, asimismo, de conseguir la mayor claridad posible en la inteligibilidad de este trabajo, lo primero que hemos de abordar es una revisión de ciertas categorías conceptuales imperantes en la historia de filosofía política en lo tocante al ámbito de esta investigación. Esto es, revisar - constructivamente, y con la vocación

de enriquecerlas y de hacerlas válidas para el caso que nos ocupa- ciertas categorías comúnmente empleadas al tratar la génesis de la modernidad política; categorías conceptuales como humanismo, humanismo cívico, republicanismo, o teología política. 
En las páginas siguientes, por lo tanto, trataremos de acotar qué entendemos en este trabajo por pensamiento republicano, por republicanismo y qué uso vamos a darle al término. Haremos un apunte también respecto al propio termino humanismo, categoría bastante difusa. Expondremos, asimismo, nuestra respetuosa crítica a aportes de tanto peso como la tesis de Hans Baron (quien acuña el concepto humanismo cívico) y su escuela, o a ciertos presupuestos sobre historia del republicanismo (sobre todo los centrados en el llamado republicanismo atlántico, teniendo en cuenta para ello principalmente el trabajo de J. G. A. Pocock y de los autores relacionados con la llamada Escuela de Cambridge). A modo de estado del arte, realizaremos de la misma manera un repaso de las críticas más importantes llevadas a cabo en las últimas décadas en torno esta categoría de humanismo cívico, así como de los debates académicos más relevantes al respecto; todo inscrito dentro del actual creciente interés en los estudios sobre republicanismo. Teniendo en cuenta todo lo anterior, en el desarrollo de nuestro capítulo justificaremos por qué la imperante denominación de humanismo cívico no opera para el caso castellano de los siglos XV y XVI (básicamente por tres razones: porque en Castilla el republicanismo es de corte escolástico, porque convive con un claro apoyo a la monarquía y porque su filosofía de la historia es escatológica), y por qué finalmente, por consiguiente, no nos decantamos por ella y proponemos una denominación alternativa: pensamiento político converso.

Ya en la tercera parte de este primer capítulo, nos detendremos brevemente, asimismo, en la noción de teología política (cargada también de una densa red de connotaciones y debates). Acotaremos cómo será usado en este trabajo, donde lo emplearemos de la manera más aséptica posible, esto es, en el sentido más literal posible, queriendo que sea entendido como articulación entre lo religioso y lo político, como una instrumentalización política de elementos teológicos, como una retroalimentación entre ambos. Y lo emplearemos queriendo ser coherentes en todo momento al utilizarlo con el contexto del XV, que en todas las dimensiones incorporaba lo trascendental, y tratando de evitar un discurso sobre la secularidad anacrónico e impostado: no pensamos que Modernidad implique necesariamente secularización (puede implicarla, al igual que otras variables, pero no es su condición suficiente y necesaria), al igual que no estimamos que republicanismo implique necesariamente una filosofía de la historia secular y que sí entendemos para nuestro caso de estudio un engarce entre elementos teológicos y republicanos. 
En definitiva, éste se perfila como un capítulo de corte metodológico, de posicionamiento conceptual y de estado del arte para acercamos a ciertas categorías conceptuales propias de la historia intelectual y de la historia de la filosofía política que están fundamentalmente vinculadas a la temática de esta investigación y al periodo que ésta comprende. Todo ello lo haremos teniendo presentes como telón de fondo los presupuestos la historia conceptual y de la reelaboración de ésta por el conocido como 'Grupo de la Universidad de Padua', así como considerando los aportes hechos por la Escuela de Cambridge en el desarrollo más reciente de la llamada nueva historia intelectual. Y lo haremos partiendo, asimismo, de una epistemología que se sitúa, y que así puede tener en cuenta lo local y puede detectar las especificidades en la implementación de las grandes corrientes en un contexto determinado, y puede además actuar críticamente frente a relatos filosóficos e historiográficos dominantes.

El presente capítulo no es sólo un ejercicio formal introductorio, sino que es un capítulo de una vital importancia para comprender la tesis en su conjunto, pues, precisamente, la crítica a las categorías hegemónicas de la historiografía política empleadas para trazar el relato dominante sobre la implementación de la modernidad política europea y sobre la historia del republicanismo, nos va a permitir sustentar las especificidades de nuestro caso (las cuales veremos más adelante), esto es, las intersecciones y las fugas del caso castellano con respecto a su contexto europeo. Y esto va a contribuir a señalar la marginación y el silenciamiento que el pensamiento político castellano del XV ha sufrido en la narración imperante, reparar en lo cual es vital para poder realizar un ejercicio de genealogía crítica de la modernidad política y una más completa y poliédrica historia del republicanismo.

\subsection{Asomarnos críticamente a ciertas categorías conceptuales imperantes y a su aplicabilidad para el caso castellano.}

Como ya esbozábamos arriba, para llevar a cabo esta revisión y crítica de ciertas categorías propias de la historia de la filosofía política posicionaremos nuestra epistemología y nuestra enunciación considerado los rasgos concretos contextuales, las tradiciones intelectuales, los lenguajes políticos y los espacios controversiales propios de la esfera de esta investigación, en este caso el ámbito castellano del siglo XV y principios del XVI. Sin embargo, lo haremos sin 
escindir este contexto específico de su entorno europeo. Todo ello con la intención concordante con el objetivo expuesto al principio - de visibilizar el pensamiento político del cuatrocientos castellano, de poner en valor sus particularidades y de explicar, como veremos, que estas particularidades no implican que en él no estén presentes elementos intrínsecos del pensamiento político del siglo XV europeo.

Teniendo en cuenta el momento que tratamos y con el fin de referirnos de un modo inteligible y certero a aquello a lo que concretamente remitimos (esto es, el pensamiento político y la teología política propios de los intelectuales judeoconversos del cuatrocientos castellano, y a la figura de Alonso de Cartagena como epítome de éstos) es preciso que nos detengamos en la cuestión de qué herramientas tenemos para nombrarlo y analizarlo. Hemos de ser cautos y hallar la forma más adecuada y menos equívoca de hacerlo, intentando no caer en la tentación del anacronismo, y tampoco de universalizar las categorías de la ciencia política moderna. Por ello, en esta revisión de categorías conceptuales, tendremos presentes los presupuestos de la historia conceptual y de la reelaboración de ésta por el conocido como 'Grupo de la Universidad de Padua', sus reflexiones en torno a los límites y las aporías internas de cómo la modernidad ha pensado su dimensión política (aunque sin hacer un estudio exhaustivo sobre éstas, pues las tomamos como apoyatura pero no son el foco de estudio de esta investigación) ${ }^{6}$. Tendremos en cuenta, asimismo, posicionamientos que ha acogido la llamada nueva historia intelectual — sobre todo desde la conocida como 'Escuela de Cambridge' - al considerar un método contextualista e historicista de interpretación desde el que afrontar las fuentes y desde el que poder hablar sobre los lenguajes políticos propios del momento estudiado ${ }^{7}$. Y entendiendo las ideas, la historia intelectual, como algo existente, frente a un método positivista. Como explica Faustino Oncina:

\footnotetext{
${ }^{6}$ Explica Sandro Chignola sobre este enfoque del 'Grupo de la Universidad de Padua': «(...) la investigación italiana ha respondido en un sentido más marcadamente filosófico al problema de la formación del léxico político europeo. Para esta segunda perspectiva, la historia de los conceptos no es tanto la consecuencia de una elección metodológica previa, cuanto el resultado de la conexión que se establece entre, de un lado, la empresa genealógica encargada de reconstruir los aparatos y órdenes lógicos fundamentales de las categorías políticas modernas y, de otro, el descubrimiento de la imposibilidad de traducir estas últimas a esquemas universales y, weberianamente, objetivos, que consigan extraer constantes o ecuaciones regulares de la modalidad y de los conceptos de la experiencia política occidental. La época de los conceptos políticos modernos — aislada por la investigación de los textos de la tradición filosófico-política occidental y organizada, a partir de esta última, como históricamente determinada - requiere necesariamente la reconstrucción en términos históricos de los propios tiempos conceptuales (...) El verdadero problema, al que sólo se puede ofrecer una solución en términos históricoconceptuales, es el de la génesis de la filosofía política moderna como ciencia política moderna (...)». Chignola (2003: 52-53).

${ }^{7}$ Puede ampliarse información al respecto en Skinner (2002).
} 
«(...) el pensamiento y el comportamiento políticos, ahora y en el pasado, no pueden ser entendidos sin referencia a los vocabularios distintivos usados por agentes en sus contextos

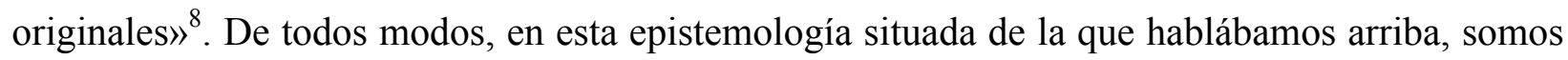
también críticos con cómo estas grandes escuelas han invisibilizado las contribuciones a la filosofía política de otros ámbitos más allá del anglosajón, centro y norte europeo. Coincidimos por ejemplo con Christopher Goto-Jones en su denuncia de que la Escuela de Cambridge tomó cierta deriva orientalista al descuidar las contribuciones no occidentales a la historia intelectual ${ }^{9}$.

Este trabajo se perfila como un ejercicio de historia del pensamiento político hispánico y como ejercicio de genealogía crítica de la modernidad hispánica, esto es, como ejercicio de historia de la filosofía política y de historia intelectual en el ámbito hispánico. Por lo tanto, como apuntábamos, orbitará en la esfera de la historia de las ideas, pero, asimismo, conectará con la historia conceptual, pues abordaremos también la problemática de cómo enfrentar ciertas categoría historiográficas pertinentes para esta investigación, y de cómo hacerlo sin caer en trampas como el anacronismo, peligro constante cuando se trabaja diacrónicamente. E intentando también no emplear ciegamente determinadas categorías historiográficas sin analizarlas. Sobre este tipo de riesgos han advertido varios estudiosos del 'Grupo de Padua' — que, a su vez, se basan y reelaboran la Begriffsgeschichte de Reinhart Koselleck - refiriéndose a la detección de estas dificultades, y planteando una propuesta para hacerse cargo de ellas. Así resume la estudiosa María Martín Gómez, las ideas al respecto de Sandro Chignola, uno de los máximos exponentes de dicho grupo (nos permitimos una cita tan extensa para mayor comprensión) ${ }^{10}$ :

Chignola se formula a sí mismo la siguiente pregunta: «¿Cómo escribir la historia de la filosofía política?» (...) En primer lugar, se trata de «radicalizar», en términos críticos, el conocimiento de los conceptos políticos. (...) Esto significa desactivar las pretensiones de universalidad de los conceptos políticos modernos ya que los esquemas interpretativos de la Modernidad tienden a condicionar nuestro acercamiento teórico a las fuentes históricas del pasado. El problema - dirá Duso- es ver «cuándo nacen los conceptos políticos que nosotros usamos, cómo han llegado a nosotros, qué contexto epocal y qué presupuestos encierran» (...) A partir de este presupuesto, los conceptos modernos deberán ser «reconducidos genealógicamente a la fractura originaria que decreta su génesis» y las fuentes del pasado dejarán de analizarse mediante conceptos modernos que no hacen sino

\footnotetext{
${ }^{8}$ Oncina (1998): 97.

${ }^{9}$ Goto-Jones (2008).

${ }^{10}$ Martín (2011): 266-268.
} 
traicionar esas mismas fuentes. (...) Y es que una vez seamos conscientes de la ruptura existente entre los conceptos antiguos y los modernos, y una vez hayamos reconocido la imposibilidad de estudiar el pasado con materiales del presente, la historia conceptual dejará de ser una metodología para convertirse en una forma de filosofar. Es filosofía porque critica lo evidente, pone de relieve la contingencia de la Modernidad y delimita el área de vigencia de las estructuras políticas.

Asimismo, es advertido el error de asimilar filosofía política con ciencia política moderna. En palabras ahora del propio Chignola $^{11}$ :

De todo ello podemos extraer (...) que sólo se puede acceder al pensamiento antiguo si evitamos hipostasiar o universalizar las categorías de la ciencia política moderna. No existe algo así como la teoría política antigua, si es que con estas palabras entendemos algo parecido al dispositivo lógico a través del cual el pensamiento moderno plasma la realidad. Por el contrario, el pensamiento filosófico político antiguo sólo podrá ser explicado como una formulación de aquella pregunta acerca de lo justo y del bien, que había sido descartada y ocultada por la ciencia política moderna.

Se ha cuestionado reiteradamente en el campo de la historia de las ideas si la modernidad se dio en el ámbito hispánico parejamente a cuando aconteció en el resto de Europa. Pareciera que en el espacio ibérico, y por ende, posteriormente, en el llamado mundo hispánico, la génesis de la modernidad hubiera sido defectiva. Y hay que hacer notar que no es que no sucediese la modernidad en España, ni que lo hiciera mucho después que en otras regiones - o que no llegase nunca- sino que ésta se implementó con sus especificidades: como ha indicado Carlos Thiebaut, se gestó lo que podríamos denominar la 'Modernidad del Sur' que tuvo sus propias características en lo filosófico, en lo socio-político, en lo teológico y en la conformación de las subjetividades $^{12}$. No es que no existiese, es que fue excluida del relato oficial historiográfico y su narración cooptada por la comprensión historiográfica y filosófica más extendida de la de modernidad. Esa modernidad hispánica no fue considerada en el relato que la historiografía filosófica ha hecho del proyecto fundacional y normativo de la Europa renacentista, esto es, de la modernidad hegemónica europea (que pareciera había de ser, sí o sí, humanista, cartesiana, protestante, liberal, capitalista, y secular en cuanto a la filosofía de la historia y la gobernanza). No sólo no cupo, sino que fue uno de sus necesarios residuos resultantes de las sabidas

\footnotetext{
${ }^{11}$ Chignola (2003): 65 .

12 Thiebaut (1989): 125. Bolívar Echeverría, por ejemplo, por su parte, habla de La modernidad de lo barroco para el caso iberoamericano. Echeverría (2000).
} 
contradicciones en el propio núcleo de esta modernidad oficial ${ }^{13}$. Es menester aclarar de todos modos que no nuestra intención aquí "competir" por cuán modernos fueron los ámbitos hispano e hispánico (que sonaría entre lo apologético y lo acomplejado), pero sí que es preciso y honesto intelectualmente hacer notar cómo se han marginado sistemáticamente del relato de la historia de la filosofía política los aportes del pensamiento político hispánico, tanto ibérico como americano.

No aplicamos aquí estos razonamientos a los ámbitos geográficos habitualmente invisibilizados (como ya han señalado los estudios poscoloniales), sino a la propia Europa y a la propia España: la Europa del Norte y el mundo anglosajón impusieron una subordinación cultural a la Europa austral (algo que al principio del Renacimiento había hecho también Italia asumiéndose centro de la producción de conocimiento), y, además, en un siniestro pliegue, la España oficial (que no la disidencia cultural e intelectual) aplicó también y reprodujo este silenciamiento epistémico del que había sido víctima dentro de sus propias entrañas. El silenciamiento epistémico interno acompañó a Castilla en su Modernidad: la "islamofobia” y la "judeofobia" trataron de consolidar una identidad oficial unívoca; a este respecto resultan reveladoras estas palabras de Rafael Herrera, que, además, refieren a nuestro autor de estudio, Alonso de Cartagena (en el cual nos detendremos ampliamente en los capítulos 3 y 4 de esta tesis) $)^{14}$ :

El fracaso de Cartagena nos alcanza hasta hoy (...) Paradójicamente, será Castilla, y el hispanismo sistémico, los que fomentarán la modernidad imperial/colonial de Bruni. El

\footnotetext{
13 De todos modos, como hemos comprobado siglos después, este modernidad septentrional imperante tampoco fue un verdadero escenario de satisfactoria aplicación de los valores del liberalismo político y el republicanismo (pese a apropiarse de un modo exclusivista de estos supuestos méritos y estas etiquetas - respaldado por todo un aparto de legitimación académica y epistémica), pues además de no construir una realidad política de justicia y simetría entre sus poblaciones, su haz de progreso generó un envés de dominación, sobre todo en las periferias.

${ }^{14}$ Herrera (2016): 101, 102, 105, 116. La traducción es nuestra. Texto original: “Cartagena's defeat reaches us today. (...) Paradoxically, it will be Castile, and the systemic Hispanism, the ones which will encourage Bruni's imperial/colonial Modernity. The first place where Cartagena lost the battle was Spain, being himself both witness and victim. This defeat spread to the rest of Europe to the present day. (...) There was a lost Modernity which survived despite defeat, whose origin traces back to the Hispanic converts of the fifteenth century (...) In the debate between Bruni and Cartagena we discover the genealogical roots of the process in significant moments of the debate, such as the one about the eccentricity of Hispania against the centrality of Italy (...) In Bruni's text we can see perfectly how in the binary game of the triumphant unidirectional Modernity is civilization (...) This is the reason why the polemic has the character of an archetype of Modernity, because in it there is a confrontation between the unidirectional, victorious, and imperial Modernity of the white man, the European, and the plural, defeated, and cosmopolitan Modernity of the mestizo, the European convert. (...) The unidirectional Modernity will progressively be configured through binary exclusions, from the human to the geographic."
} 
primer lugar donde Cartagena perdió la batalla fue en España, siendo él mismo testigo y víctima. Esta derrota se extendió al resto de Europa hasta la actualidad (...) Hubo una Modernidad perdida que sobrevivió a pesar de la derrota, cuyo origen se remonta a los conversos hispanos del siglo XV (...) En el debate Bruni y Cartagena descubrimos las raíces genealógicas del proceso en fragmentos significativos del debate, como el de la excentricidad de Hispania frente a la centralidad de Italia (...) En el texto de Bruni podemos ver perfectamente cómo, en el juego binario triunfal de la Modernidad unidireccional, ésta es identificada con la civilización. Esta es la razón por la cual la polémica tiene el carácter de un arquetipo de la Modernidad, pues en ella hay una confrontación entre la Modernidad unidireccional, victoriosa e imperial del hombre blanco — el europeo - y la Modernidad plural, derrotada y cosmopolita del mestizo — del europeo converso-. La Modernidad unidireccional se configurará progresivamente a través de exclusiones binarias, desde lo humano hasta lo geográfico.

España quiso obviar su contexto polifónico y, como indica lúcidamente José Medina, en la lucha contra el silenciamiento epistémico - y político, añadamos-, en la lucha contra la «injusticia hermenéutica», hay que reivindicar la polifonía. Afirma este estudioso: «Yo sostengo que una contextualización matizada más polifónicamente, ofrece un retrato más adecuado acerca de lo que significa romper los silencios sociales y reparar las injusticias hermenéuticas asociadas a éstos» ${ }^{15}$. Es, precisamente, este trabajo un intento por visibilizar, sacar del silencio y del olvido académicos y poner en valor la ratio política de los pensadores castellanos del siglo XV, sobre todo de los intelectuales judeoconversos, con Alonso de Cartagena como uno de sus máximos exponentes (y como autor central de este trabajo), así como un intento de entender las consecuencias que para la modernidad hispánica tuvo dicho pensamiento político.

A diferencia del enfoque más generalizado, nuestra opinión es que no puede tenerse una concepción lineal de la Historia, en la que unos periodos "superan" a otros en una suerte de línea ascendente de desarrollo, así que, en cualquier caso, describir un ámbito como el hispánico tratando de probar que sí "alcanzó" esta modernidad arquetípica septentrional — tal y como normativamente se ha presentado por el relato historiográfico - no es nuestro propósito. Lo que sí pretendemos, sin embargo, es explicar que la propia modernidad temprana tuvo diversas caras y formas de implementación, y que todas ellas son válidas. Ningún periodo, pese a estar condensado bajo una etiqueta historiográfica o intelectual, habríamos de verlo como un ente

\footnotetext{
${ }^{15}$ Medina (2012): 201. La traducción es nuestra. Texto original: "I contend that a more nuanced—polyphonic contextualization offers a more adequate picture of what it means to break social silences and to repair the hermeneutical injustices associated with them".
} 
unificado y hermético, esto sería uniformarlo y no comprenderlo con su inherente variedad de líneas de pensamiento, y de lenguajes y prácticas políticas, todas ellas permeables y en intercambio.

Este cuestionar sobre la modernidad hispánica generalizado del que hablábamos arriba se remonta a dudar de si en Castilla hubo un verdadero pensamiento político renacentista: la complejidad de la Península durante el siglo XV, y ante todo una lectura sesgada y errada de la época posterior, así como una mala comprensión del absolutismo hispánico, han condicionado una comprensión anacrónica y tergiversada incluso de periodos previos a la Contrarreforma. Todo ello lo analizaremos en el Capítulo 2 al hablar sobre la monarquía en Castilla.

En medio de una nebulosa de prejuicios, ha parecido presuponerse que no se dio una verdadera filosofía política como tal en la Castilla del cuatrocientos, y que ésta quedó ahogada en laberintos escolásticos tejidos por clérigos tan sólo preocupados por ejercicios teológicoespeculativos y por cuestiones doctrinales, y sin ningún interés por la filosofía práctica ni sobre cuestiones políticas, morales o jurídicas de su entorno. Esto sería consecuencia de interpretar y juzgar - restrictivamente el panorama castellano del cuatrocientos bajo la comprensión actual de nociones como monarquí, representatividad, contractualismo, constitucionalismo, participación, control de la autoridad, soberanía o secularismo. Sería consecuencia, por tanto, de asimilar e interpretar, tal y como veremos más adelante, de un modo reduccionista y anacrónico la noción de republicanismo. Y sería, asimismo, resultado de querer identificar modernidad política con humanismo cívico (tal y como está descrita esta categoría de la historiografía política, algo que desgranaremos en breve), y, a su vez, de identificar éste con republicanismo, un doble salto al vacío del que genera serios problemas para entender las especificidades del caso hispánico. Como decimos, en seguida, en el punto 1.3 (titulado «Acerca de la categorías de republicanismo y humanismo cívico») desarrollaremos ampliamente estas ideas, pero antes, esto es, en el siguiente punto, el 1.2, es obligado detenerse en la propia categoría de humanismo, término también complejo; así como realizar algunas aclaraciones, entre ellas una cierta defensa de la escolástica hispánica y de su vínculo con cuestiones políticas en los albores de la modernidad. 


\subsection{El concepto humanismo. Problematización del término para este trabajo. Una lanza a} favor de la escolástica.

No es fácil y podría parecer soberbio querer entrar aquí a diseccionar un concepto tan utilizado y amplio como el de humanismo. No lo pretendemos, sino tan sólo señalar cómo dicha categoría se ha ligado mayoritariamente a una serie de características bastante rígidas que la definen, con la subsiguiente problemática que eso puede implicar a la hora de considerar si tal o cual autor o corriente "fue" o "no fue" humanista. Como es sabido, generalmente, el humanismo se ha descrito como un gran movimiento cultural, filosófico y antropológico, incluso como una suerte de programa civilizatorio, pero también como un proyecto metodológico y epistemológico.

Hay que aclarar antes de seguir que vinculamos aquí la noción de humanismo con lo textual, y no con otros lenguajes y regímenes como el escópico, algo que abordarían los Estudios Visuales y la Historia del Arte al afrontar el humanismo como movimiento plástico, arquitectónico, etc.- . No pensamos tampoco en el humanismo filológico, sino más bien en las aristas filosóficas del llamado humanismo, en su dimensión filosófica, sobre todo en lo tocante a la filosofía política y la teología política ${ }^{16}$.

\footnotetext{
${ }^{16}$ Sin embargo, apuntar someramente, que tanto en la historia de la literatura, como en sectores de la historia de las ideas, el humanismo ha sido considerado, sobre todo, como una revolución cultural ligada a un movimiento filológico, algo que no podemos dejar de mencionar. Esta concepción filológica la siguieron estudiosos como Paul Oskar Kristeller (1993), Eugenio Garin (1981 y 1992), Ottavio Di Camillo (1976), Daniel J. Siegel (1966) o Franciso Rico (1978 y 1993). Para el reconocido académico P.O. Kristeller: la idea fundamental que recalcar es que el término humanismo, en su sentido originario y correcto, no se refiere a una determinada corriente filosófica, no a grandes aportaciones al pensamiento especulativo, sino a un proyecto cultural. Citamos sus palabras (1993:41): «El humanismo renacentista no era como tal una tendencia o un sistema filosófico, sino más bien un programa cultural y educativo en el cual se enfocaba y desarrollaba un campo de estudios importante pero limitado». Sin embargo, reconoce que no seríamos tampoco fieles a la realidad si no reconociésemos a los humanistas su vital labor como abonadores del terreno donde germina la revolución de la filosofía moderna además de su contribución a revivificar algunas doctrinas filosóficas clásicas. Según este enfoque filológico de Kristeller del concepto que nos ocupa, uno de los rasgos por los que sobresalen los humanistas es por su entusiasmo por la literatura clásica, entroncándose directamente con la tradición retórica occidental (que se remonta a los sofistas). La literatura se tornará epicentro de su dedicación - si bien es cierto que a lo largo del siglo XV van extendiendo sus studia humanitatis cada vez más hacia la filosofía- - y los concibe como herederos de los 'dictadores' medievales. La aportación de los humanistas frente a éstos es el estudio y emulación de los clásicos así como el enorme empuje de tratados y diálogos. Asimismo, se señala desde la Filología que otro quehacer característico de los humanistas fue el de ser renovadores en la forma de realizar las traducciones, cuestión ésta importante, pues en última instancia es uno de los factores que permite que se produzca el fenómeno cultural mismo que nos ocupa. Se traduce mucho, gracias a lo cual las obras clásicas alcanzan mayor difusión, pero, sobre todo, se traduce diferentemente. Al decir esto a lo que nos referimos es a que se traduce con la intención de volver al texto original, ya sin el tradicional aparato de glosas. Siguiendo con Kristeller, éste opina que el que se dé una revolución de pensamiento como la que tiene lugar no es por la llegada de autores totalmente desconocidos hasta entonces, sino porque se reinterpreta la Antigüedad, y esto es factible gracias
} 
Pese a su utilidad descriptiva, por estar en el acervo común, hay diversos autores que prefieren no utilizar esta categoría historiográfica de humanismo, o hacerlo precavidamente, sobre todo cuando se trata del pensamiento político, también nosotros asumimos esta postura (más si cabe considerando nuestro objeto de estudio). De hecho, hay estudiosos muy renuentes con tal denominación, por ejemplo, Jesús R. Velasco, quien estima que es sólo una categoría historiográfica demasiado artificial, y que es irreal y demasiado difusa; incluso, para otros es un concepto es casi peyorativo, en el sentido de que es más una categoría sociológica-profesional que intelectual, así lo expone por ejemplo James Hankins ${ }^{17}$.

Comúnmente se ha explicado que, relacionado con la aventura intelectual y espiritual que supuso para los humanistas la definición del hombre y la emoción que les reverenció ante la afirmación de sus capacidades, está el hecho de que los humanistas asumieran la filosofía, ante todo, como una disciplina capaz de ofrecer herramientas para fundar una moral a la medida del hombre, y como un vehículo de acercamiento a la virtud y a la autorrealización. La contraparte de este alto ideal, como señala Consolación Baranda, fue que este enfoque —aderezado con el característico eclecticismo que profesaron - rebajó a veces el rigor filosófico y filológico de los humanistas: hicieron muchas veces oídos sordos a los aspectos más peliagudos de los autores clásicos a los que seguían o forzaron, mediante piruetas retóricas, ciertas doctrinas de la Antigüedad para adaptarlas a su cosmovisión ${ }^{18}$. Por su parte, Domingo Ynduráin recalca la ligazón entre las pretensiones de poder y la producción intelectual de los humanistas, ya que en la mayoría de ocasiones desempeñaron cargos en ámbitos cortesanos. Apunta, asimismo, que la revolución humanista surgió porque existía una coyuntura que lo requería (por tanto, el humanismo sería más una consecuencia que una causa de la evolución social), en palabras del estudioso $^{19}$ :

\footnotetext{
al nuevo enfoque a la hora de traducir. La pulcritud de las traducciones es mayor: se tiene más acceso a las fuentes, se permite más libertad al traductor y hay un nivel filológico y una conciencia de la importancia de un uso no arbitrario del lenguaje.

${ }^{17}$ Velasco (2009), Hankins (1998).

${ }^{18}$ Baranda (2004): 43, nota 41.

${ }^{19}$ Ynduráin (1994): 76.
} 
Las cosas suelen aparecer cuando se las necesita, cuando se dan las condiciones objetivas, como suele decirse. En consecuencia, no me cabe duda, de que la reaparición de la filosofía como saber autónomo e independiente, o independizado, de la teología, la teoría de la doble verdad, la atención a las cosas y los fenómenos individuales, la pugna entre vida activa y contemplativa o el populismo religioso forman parte de un mismo proceso, o, si se prefiere, son manifestaciones de una misma situación, como respuestas diferentes, a problemas comunes.

Lamentablemente, los diversos desarrollos académicos, con sus respectivas creaciones de significantes para explicar esta noción de humanismo -así, humanismo filológico, humanismo cívico, humanismo político, humanismo cristiano, etc. - han expuesto las características propias de cada uno de estos sintagmas categorizadores casi siempre de modo excluyente, es decir, como una suerte de características que hay "obligatoriamente" que cumplir para poder ser considerado humanista. De alguna manera considerando al humanismo como un objetivo de progreso frente a lo medieval que debe ser superado, considerando al humanismo como un posibilitador de acceso a la modernidad. Esta lectura, pese a ser un tanto maniquea y simplista ha operado en el sentido común de la historia de las ideas occidental. Sin embargo, nuestra postura, no concuerda con estas categorías estancas, no por relativismo, sino porque entendemos que el llamado humanismo se implementó de diversas formas en las distintas latitudes, y que hibridó en cada caso diversos porcentajes de las propiedades con las que se lo ha descrito. Propiedades que, entendemos, no eran necesariamente excluyentes, ni entre sí, ni con su herencia intelectual medieval inmediatamente previa. Como sugiriera Rafael Lapesa, habríamos de entender el humanismo como «una adquisición sin pérdidas» ${ }^{20}$.

No hemos de ceder a la tentación de describir el humanismo basándonos sólo en su oposición con el escolasticismo, o sea, estudiarlo "por reacción", o creer que el humanismo fue ex novo y supuso una absoluta ruptura con la tradición medieval que lo antecedió. Estimamos que es un artificio el asumirlo como la irrupción y el sobrevenimiento de una serie de ideas sin herencia, o tan sólo con una herencia en la Antigüedad clásica. Por ejemplo, cabría preguntarse: ¿Cómo pretender entender el republicanismo o el constitucionalismo renacentistas sin tener en cuenta elementos como la escolástica tomista del siglo XIII o el conciliarismo? Tampoco deberían presuponerse como baremo de lo que es modernidad política o filosófica, y de lo que no

\footnotetext{
${ }^{20}$ Lapesa (1982).
} 
lo es, las características en exclusiva del humanismo italiano o de la modernidad política del Norte de Europa y el mundo anglosajón. Como se pregunta retóricamente Fernando Miguel Pérez Herranz: «¿Dónde está escrito que hay que pasar por el humanismo italianizante para ganarse el derecho a entrar en la historia de la filosofía?», y prosigue preguntándose ${ }^{21}$ :

¿Qué hacer con la corte de Juan II [de Castilla] en el siglo XV? En vez de estudiarla desde los problemas de los reinos fronterizos, con ciudades mixtas y mezcladas, se buscan etiquetas para conectarla con el Renacimiento italiano y salvaguardar su honra: «atmósfera prehumanista (Di Camillo), «incipiente humanismo» (Gascón Vera apud Di Camillo), «humanismo vernáculo» (Lawrence) o «prerrenacimiento» (Lida de Malkiel, Maravall)...

No deberían vincularse metonímicamente - para luego generalizarse - términos como humanismo, humanismo cívico o republicanismo sólo a un escenario y a una sola tradición intelectual. Sin embargo, como veremos en seguida, así ha sido, por ello el uso de estos términos se problematiza.

Por tanto, aquello por lo que nos resulta complicado emplear en este trabajo la categoría de humanismo, es que su uso parece implicar en sí mismo la aquiescencia con la idea de que ciertos temas son "exclusivos" del humanismo; temas que, para más enjundia, supuestamente han de presentarse con un formato propiamente humanista. Y nos resulta complicado también porque el pensamiento político gestado por los protagonistas del caso que nos ocupa - esto es, los pensadores conversos castellanos de los siglos XV y XVI, en concreto Alonso de Cartagena— sí compartía características y tópicos catalogados como propios del humanismo político, pero no todos, $\mathrm{y}$, además, no lo hacía con un formato plenamente humanista, sino con muchos elementos escolásticos. Aparte, estos intelectuales no tenían una auto-asunción de ruptura con lo medieval y eran conscientes de que cuestiones que estaban reverberando con fuerza en su cotidianidad no habían sido recuperadas de la Antigüedad directamente, sino que se habían mantenido y repensado en la Edad Media. Es cierto que determinadas cuestiones propias de la recuperación del republicanismo clásico como el desarrollo de la vita activa a través de la participación en el vivere civile, la idea de libertad como no dominación, los debates sobre el origen de la autoridad del poder político y sobre su legitimidad y el control arbitrario de su ejercicio, o las teorías sobre

\footnotetext{
${ }^{21}$ Pérez Herranz (2016): 255-256.
} 
el gobierno mixto, etc. aumentaron su importancia en las reflexiones y prácticas políticas bajo el prisma del llamado humanismo, pero esto en absoluto implica que éstos fueran temas nuevos propios del mismo, ya eran tópicos trabajados por el pensamiento escolástico europeo de los siglos previos. En seguida nos detendremos brevemente en ello.

Ciertamente, y paradójicamente, el concepto humanismo, tal y como está descrito habitualmente, es demasiado vago, pero a la par restrictivo y limitante, excluyente para todo aquello que no cumple con los rasgos que se enuncian como inherentes a él, o para aquello que los cumple sólo parcialmente. Esto es, se nos presentan una suerte de características que hay que cumplir para poder ser considerado humanista, en oposición a lo que todavía no puede considerarse humanista por ser demasiado medieval o demasiado escolástico, o a lo que no es lo suficientemente secular para ser humanista, a lo que no es lo suficientemente republicano para ser humanista, etc., aseveraciones éstas que no compartimos. Estimamos que el llamado humanismo — si materializamos la categoría y la pensamos ya como fenómeno-, y concretamente la dimensión política del humanismo, se implementó de diversas formas en las distintas latitudes. Entendemos este fenómeno tan amplio, aglutinado en torno a la categoría de humanismo, como un movimiento vastísimo y poliédrico y creemos que habríamos de pensarlo siempre integrando tanto sus múltiples dimensiones como sus diversas implementaciones. El humanismo tuvo sus particularidades en los distintos contextos en los que germinó, es innegable la importantísima impronta del humanismo italiano, pero, como explica Ángel Gómez Moreno, no única ${ }^{22}$. Además, en la Castilla del XV, así como en la herencia intelectual de ésta, eran ubicuos los rasgos árabes y semíticos — los cuales no alejaban de la recuperación del pensamiento clásico o del racionalismo, más bien al contrario- pero, generalmente el humanismo como está descrito no contempla lo árabo-semítico.

Como indica Fernando Miguel Pérez Herranz, tomando a su vez la información de Marcel Bataillon, este problema ya lo reflejó en 1520 fray Diego López de Zúñiga en su Annotationes contra Erasmum Roterodamum in defensionem translationis Novi Testamenti al reivindicar la ciencia y la cultura española y latina frente al desprecio que de ella tenían los

\footnotetext{
${ }^{22}$ Gómez Moreno (1994).
} 
«hijos de Norte» ${ }^{23}$. Otra cuestión relevante que señala Pérez Herranz y que hemos de tener en cuenta es que el pensamiento hispánico no siempre se sistematizó de la misma manera que en otros lares, hace notar: «Y la propia filosofía se desplegó en muchas ocasiones con tintes de esplendorosa genialidad, si entendemos con Unamuno que el pensamiento filosófico se encuentra diluido en la literatura, en la acción mística» ${ }^{24}$. Y cita al salmantino, que dice en su lúcido $E l$ sentimiento trágico de la vida: «Pues la filosofía española está líquida y difusa en nuestra literatura, en nuestra vida, en nuestra acción, en nuestra mística, sobre todo, y no en sistemas filosóficos (...) Las coplas de Jorge Manrique, el Romancero, el Quijote, La vida es sueño, la Subida al Monte Carmelo [la Celestina o la picaresca, nos permitimos añadir], implican una intuición del mundo y un concepto de la vida» ${ }^{25}$. Sin embargo, a partir del Renacimiento quedará fijada y tendremos que acatar la separación entre géneros literarios y filosóficos, división artificial para el caso hispánico.

Para entender esta visión reduccionista del ámbito hispánico diversos estudiosos han buscado razones diacrónicas en el racismo y el orientalismo — enquistados durante siglos - de la Europa más septentrional hacia la más austral, una hispanofobia, según ellos, consecuencia de varias razones: el antiimperialismo, la pugna entre protestantismo y catolicismo, el antisemitismo y anti-islamismo, y la conocida como Leyenda Negra (con el monopolio de ésta en el discurso dominante en las grandes narrativas de la historia de la ideas y la subsiguiente aceptación sin queja de España al respecto).

Volviendo a la cuestión del uso del término humanismo, quepa también hace notar, que, para mayor confusión, la propia manera en la que se han elaborado las ramificaciones y clasificaciones académicas del humanismo hace a veces que parezcan casi contrapuestas sus ramas. Así: el humanismo cristiano (en el que entrarían paradigmáticamente autores como los neoplatónicos italianos, por ejemplo Marsilio Ficino, Lorenzo Valla, Pico della Mirandola, o Pietro Pomponazzi, interesados por tópicos como el de la dignitas hominis, el debate sobre la inmortalidad del alma, el intimismo religioso, cierto diálogo interreligioso o la renovación espiritual, entre otros) y el humanismo político — del que nos ocupamos en este trabajo- serían

\footnotetext{
${ }^{23}$ Pérez Herranz (2016): 250.

${ }^{24}$ Pérez Herranz (2016): 251.

${ }^{25}$ Unamuno (1986): 279.
} 
presentadas como en mucho excluyentes tal y como la academia los ha descrito (algo que no compartimos): el primero de corte neoplatónico, promotor de una teleología de la virtud a través de la vida contemplativa y el conocimiento, y el segundo transido de la lectura política del aristotelismo y promotor de una teleología de la virtud en el desarrollo de la vita activa en el ámbito de la vida civil. En lo que sí coincidirían, de acuerdo al tradicional enfoque de la historia de las ideas, los distintos tipos de humanismo, sería en su nuevo enfoque metodológico y epistemológico, opuesto a la escolástica. La escolástica se nos acaba mostrando como el gran enemigo y antecedente que superar, algo que no consideramos ni acertado ni justo, y que, además, para el caso castellano es del todo inexacto.

Antes de seguir, sobre todo teniendo en cuenta esto que acabamos de apuntar de que a veces el humanismo se ha definido en oposición a la escolástica, pensamos que es conveniente hacer un muy somero apunte sobre el papel de ésta, en los siglos XV y XVI (algo que desarrollaremos ampliamente para el caso castellano en el capítulo segundo al hablar de la Universidad de Salamanca, del vínculo entre escolástica y Derecho y de la función social del letrado). De algún modo lo que queremos hacer aquí es levantar una lanza a favor del papel de la escolástica en el cuatrocientos castellano, hacerle una suerte de defensa. Un defensa frente a esa actitud que podría sintetizar aquel despectivo e irónico península escolástica con el que se refería Voltaire a la península Ibérica. Más que nada queremos señalar importancia y los aportes que teólogos y juristas de corte escolástico realizaron en el espectro del pensamiento político. La escolástica fue un modelo epistémico y un método de pensamiento sumamente preocupado por cuestiones morales y políticas concretas, y fue soporte para debates y controversias al respecto, no implicó en absoluto un ensimismamiento teológico alejado de las problemáticas sociales.

Deberíamos partir de comprender el humanismo como un método, al igual que lo es la escolástica, y recordar que esto no implicaba que hubiera temas o intereses exclusivos de cada uno, o vetados para alguno. El método escolástico empleaba el criterio de autoridad (sobre todo de fuentes como la Biblia, la Patrística, Platón, Aristóteles, Cicerón, Séneca, las compilaciones jurídicas, o las sumas de autores como Tomás de Aquino, Guillermo de Ockham o Duns Escoto), la argumentación lógica, el conocimiento acumulativo y los exempla históricos para abordar problemáticas, las cuales desgranaba en supuestos y cuestiones específicas que iba analizando y 
resolviendo sistemáticamente. Es cierto que el humanismo como programa es propio del Renacimiento, pero no hay por ello que describir este momento que la historiografía ha llamado Renacimiento como una superación de la escolástica. En cuanto al pensamiento político, es cierto también que parte de la escolástica deviene forma argumentativa para teorías que defienden el absolutismo o la razón de Estado, pero eso no implica que estas posturas sean inherentes al método escolástico. Desarrollos escolásticos como su particular recuperación del aristotelismo, su tomismo, su nominalismo o su voluntarismo, no son para nada incompatibles con los valores republicanos, de hecho éstos ya se recuperaron en la Edad Media y fue la escolástica su gran transmisora. Es más, fue adalid y vía para recuperar cuestiones como la necesidad de limitar la autoridad del gobernante (por ejemplo en las discusiones en torno a que el origen de la autoridad reside en la comunidad política que posteriormente la transfiere al gobernante, o en contra de la tiranía), la importancia del Derecho Natural (en base al cual se sustentan posturas contractualistas), o para ahondar en posturas parlamentaristas gracias al conciliarismo. Otro aspecto susceptible de hacer notar es que, la escolástica se desarrolló en diversos espacios, esto es, no sólo en los núcleos de poder político, sino también en universidades y ámbitos clericales, relación con el ámbito académico la cual le permitió cierta cuota de independencia; además, el uso del latín como lengua franca ayudaba a poder compartir el conocimiento.

No deberían olvidar quienes hablan del humanismo de un modo casi totalizador, que en la primera modernidad conviven muchas líneas de pensamiento, métodos de conocimiento y lenguajes políticos diversos.

Teniendo en cuenta la variable cronológica y ciertas características del pensamiento político objeto de nuestro estudio, es verdad que el primer término que parecería lógico y sería tentador utilizar para describirlo sería humanismo (especificado luego como humanismo político o humanismo cívico). Pero usarlo es tan útil como peligroso. Útil para lograr una mayor comprensión inicial, más agilidad y efectividad en la comunicación, pero peligroso porque dicho término, ya más bien un concepto, tiene toda una estela de interpretaciones y acotaciones a sus espaldas. Y, como venimos apuntando, algunas de ellas son unívocas y restrictivas. Interpretaciones de lo que es y lo que implica el concepto de humanismo que es preciso decantar, 
pues la cuestión no atañe sólo a lo formal denotativo lingüístico, sino que el hecho de cómo se rellena el significante humanismo, entraña diferentes enfoques de la historia de la ideas y de cómo estos enfoques asumen y se relacionan con aspectos como la filosofía de la historia, los marcos epistémicos, los regímenes políticos, la secularización o la hegemonía intelectual. Así, como veremos con detenimiento en el punto 1.3, sintagmas como humanismo cívico o humanismo político, empleados en la historia del pensamiento político no resultan un inocuo binomio, sino que responden a unas determinadas reconstrucción y consideración académicas de lo que fue el humanismo en su faceta política y a un concreto relato de la historia del republicanismo.

Por todo lo anterior, al acotar, al nombrar esta investigación, al titularla, no hemos empleado deliberadamente el término humanista. Lo que hemos denominado «pensamiento político converso» del siglo XV castellano podríamos haberlo llamado también «humanismo político converso», y de hecho, con este título tal vez sería más fácilmente inteligible a qué nos referimos, pero estaríamos incurriendo en contradicciones de base y reproduciendo categorías historiográficas rígidas y con una carga valorativa que no compartimos. Y estaríamos también falseando u ocultando características propias de nuestro contexto de estudio con tal de poder entrar en la categoría humanista tal y como suele estar descrita. Sin embargo, el optar por no incluir el término humanista en el apelativo con el que intentamos condensar nuestro objeto de estudio, tiene el riesgo y el perjuicio de que así llamado, a simple vista, pudiera parecer que este pensamiento político converso castellano del XV no participa de rasgos tipificados como propios del humanismo, sobre todo del humanismo político. A pesar de ello, preferimos dejarlo así, esto es, pensamiento político converso (o pensamiento republicano converso), también por el hecho de que de rasgos como por ejemplo la recuperación del republicanismo clásico no pensamos que tenga la patente exclusiva el humanismo; además, hay otros rasgos considerados como típicamente humanistas (sobre todo en lo formal) que nuestro objeto de estudio no cumpliría. Así, en este pensamiento converso del $X V$ (del cual en el capítulo segundo explicaremos sus características), con la figura de Alonso de Cartagena como clímax, se hibridan elementos teológicos, un formato escolástico, una filosofía de la historia escatológica (todo lo cual se asume 
como medieval), con elementos políticos republicanos ${ }^{26}$. Y esta hibridez no la entendemos como una debilidad, o como una falta de pureza en cuán humanista o cuán moderno se es, sino como una característica intrínseca al caso castellano, característica no baladí, pues será definitoria para toda la conformación del llamado pensamiento hispánico; más adelante abordaremos todo ello.

Aclarado esto, y ya centrándonos en la dimensión política propia del cuatrocientos europeo y en la narrativa académica del mismo, el concepto en el que debemos detenernos ahora - y que, asimismo, hemos de revisar críticamente - es el de humanismo cívico. Sin embargo, antes hemos de hacer un apunte también sobre qué entendemos por republicanismo, pues este término estará en la base de las descripciones acerca de en qué consiste el humanismo cívico que abordaremos después.

\subsection{Acerca de las categorías de republicanismo y humanismo cívico. Nuestra propuesta de denominación para el caso castellano: pensamiento político converso.}

Con este punto entramos en el meollo de este capítulo y de nuestra propuesta crítica presentada en el mismo, la cual consistirá en la revisión de la categoría de humanismo cívico y la demostración de lo inadecuado de asimilar plenamente este concepto con el de republicanismo, o con el de republicanismo clásico; así como de lo inapropiado de universalizar este concepto de humanismo cívico para describir en qué consistió la faceta política del pensamiento político del cuatrocientos y el quinientos. Plantearemos, por tanto, nuestra respetuosa crítica a la conocida como tesis de Hans Baron (quien acuña este concepto de humanismo cívico) y su escuela, o a la historia del republicanismo centrada en el llamado republicanismo atlántico, teniendo en cuenta sobre todo el trabajo de J. G. A. Pocock. Y también, a modo de estado del arte, haremos notar diversas críticas a dicha categoría de humanismo cívico y a la identificación de republicanismo con republicanismo atlántico anglosajón, y lo haremos repasando los debates académicos al respecto acometidos por autores como James Hankins, Athanasios Moulakis, Guido Cappelli,

\footnotetext{
${ }^{26}$ Conviene aclarar que, aunque en nuestro caso de estudio - el pensamiento político converso castellano del siglo XV y principios del XVI - haya esta articulación con lo religioso, no aplicaría tampoco como correcta la etiqueta humanismo cristiano (adaptada a los neoplatónicos italianos como Ficino, Pico della Mirandola o Pomponazzi, etc.), pues aunque en ambos casos se comparte el tener en presente la dimensión escatológica y religiosa en la fiosofía de la historia, el humanismo cristiano no contempló del mismo modo la recuperación del republicanismo clásico y el aristotelismo político, y tampoco promovió una filosofía moral vinculada a la vita activa.
} 
Juan Varela-Portas, John Elliott, Quentin Skinner, Lucia Gualdo, Thomas Pangle, Daniel Siegel o Christopher Celenza), entre otros ${ }^{27}$. Todo ello, con el objetivo, además, de incorporar elementos de sus revisiones a nuestra propia crítica al concepto de humanismo civico para el caso castellano. Sin embargo $-\mathrm{y}$ precisamente por esta poco exacta, pero casi ubicua, asimilación entre republicanismo y humanismo cívico - primeramente tenemos que detenernos en explicar qué entendemos por republicanismo en el contexto epocal que nos ocupa (lo cual haremos en el punto 1.3.1). Posteriormente, abordaremos la revisión de la etiqueta humanismo cívico (punto 1.3.2) y expondremos varias críticas a ésta (punto 1.3.3), entre ellas finalmente la nuestra (punto 1.3.4), basada en la no aplicabilidad —explicaremos el porqué — de este etiqueta de la historia de la filosofía política para el caso castellano; asimismo expondremos nuestra propuesta de denominación - pensamiento político converso - para el caso que nos ocupa y adelantaremos sus características principales, en el desarrollo de las cuales y en la explicación del contexto que las cataliza consiste el capítulo segundo.

\subsection{1 ¿Cómo entendemos en esta tesis el término republicanismo?}

Lo primero que conviene recordar al encarar este apartado es que republicanismo es una categoría analítica utilizada por la filosofía política, la ciencia política y la historiografía política posteriores al segmento temporal que aborda nuestro trabajo, es decir, la categoría de republicanismo es un constructo teórico, una etiqueta académica muy posterior, no utilizado como tal, por tanto, en los siglos XV y XVI ${ }^{28}$. Sí era habitual en la tratadística de la época la presencia del término república, o res publica, utilizada en la acepción clásica de la cuestión pública, esto es, lo común que a todos atañe y repercute en la vida en sociedad, la entidad política organizada en pro del bien común y regida por una serie de normas que organiza la vida social. Dicha acepción de república como cuerpo o entidad política estructurada con el fin de lograr el bien común para los ciudadanos, no especificaba ni excluía a ninguna de las tradicionales formas de gobierno ya señaladas por Aristóteles: monarquía, aristocracia o democracia, esto es, era compatible con todas, siempre y cuando estas formas de gobierno tuvieran como fin el bien común, estuviesen estructuradas en torno a la justicia y la ley, y

\footnotetext{
${ }^{27}$ Hankins (1994) (1995) (1998) (2010), Moulakis (2011), Cappelli (2006) (2009) (2011) (2014), Elliott (2005) (2006), Skinner (1985) (1999) (2002) (2004) (2010), Gualdo (2005), Pangle (1988), Siegel (1966) o Celenza (2004).

${ }^{28}$ Sobre el uso y la evolución del concepto republicanismo, véase Rodgers (1992).
} 
permitieran la participación, la libertad y la equidad. Se usaba también en los textos de los siglos XV y XVI el término república para referirse a cuerpos políticos ordenados, ya fueran por ejemplo un reino o una ciudad.

No obstante, como decimos, y queremos insistir con vehemencia en ello, para evitar equívocos, aunque la categoría republicanismo sea una categoría académica creada y desarrollada en los últimos siglos, nos parece pertinente usarla: tanto en general a lo largo de esta tesis - pues resulta una categoría analítica que aporta claridad descriptiva, valor heurístico, y, es en definitiva, de mucha utilidad para el tema que nos ocupa (además renunciar a ella sería entrar en un historicismo tan extremo que, nos dificultaría la posibilidad de abstracción filosófica), pues aquí estamos revisando, precisamente, las categorías filosóficas e historiográficas con las que se ha descrito parte de la filosofía política de la temprana modernidad, y una de ellas es, sin duda, la de republicanismo.

Conviene detenerse en esto, pues en el acervo común -sobre todo en usos no académicos - se incurre en la frecuente confusión y error de equiparar republicanismo con una forma de gobierno, en concreto con 'no monarquía', pero la noción de república como la estamos abordando aquí tiene que ver con la idea de lo común, del espacio político común, de, como su nombre indica, la res publica, y cuando hablamos de valores republicanos es con esto con lo que tienen relación. También dentro del ámbito académico se ha propiciado a veces esta errónea asociación, pues ha parecido sugerirse que los ideales republicanos, que en seguida esbozaremos, no cupieran bajo la forma de gobierno de la monarquía (esto lo desmentiremos y veremos con detalle en el punto 1.3.2 al revisar la categoría de humanismo cívico, asimilada, inexactamente, con republicanismo). Al fin y al cabo, lo más importante para la existencia de valores republicanos no es la forma de gobierno, de las tres no corrompidas que planteara Aristóteles, sino que el objetivo del gobierno sea el bien común y la felicitas. Ha de haber una conjunción entre la ciudad física y la ciudad moral (a este respecto recordar que no entendemos la categoría de ciudad en términos legales —o sea, como jurisdicción—, ni físicos, o sea, geográficos, sino en clave republicana, esto es, como ámbito de desarrollo de la virtud civil a través de la participación del hombre libre) 
Volviendo a poner la alerta sobre esta confusión de asumir república en el sentido de 'no reino', resulta clarificador este apunte de James Hankins: «La idea de que una república es la única forma legítima de gobierno y que la monarquía no electiva y los privilegios políticos hereditarios son por definición ilegítimos es un artefacto del republicanismo de fines del siglo XVIII, aunque tiene sus raíces en las "repúblicas piadosas" del siglo XVII. Presupone entender una república (res publica) como una forma de gobierno no monárquica» ${ }^{29}$. Explica este profesor que esta tendencia se basó en la célebre máxima de Lorenzo Valla :«Ubi rex est, ibi res publica non est», y afirma también Hankins ${ }^{30}$ :

En el siglo XIX, los sentidos más antiguos de la palabra república se desvanecerían, y el moderno sentido exclusivista de la palabra como un gobierno legítimo que representa al pueblo, contrastado en una oposición binaria con el despotismo o la tiranía, llegaría a dominar el discurso político. (...) [Los historiadores modernos del pensamiento político] Por lo menos deben ser conscientes de que usar el término "republicano" acríticamente en su sentido moderno y exclusivista al describir el pensamiento de los escritores premodernos, es una invitación al anacronismo y la miopía histórica.

En las últimas décadas, sobre todo a partir de los años sesenta del siglo XX, dentro de la filosofía política y de la ciencia política se ha dado un creciente interés por los estudios sobre republicanismo, el llamado neorrepublicanismo, con la idea de fondo - generalizando mucho, si se nos permite - de que el rescate de los valores propios del republicanismo es útil en el objetivo de recuperación del proyecto democrático, esencialmente dañado en la actualidad. Este resurgimiento del interés por el republicanismo ha estado a cargo de importantes pensadores y estudiosos tales como, Hans Baron, John Pocock, Quentin Skinner, Maurizio Viroli, Norberto Bobbio, Philip Pettit, Jean-Fabien Spitz, Bruce Ackerman, Thomas Pangle, Ernesto Laclau y Chantal Mouffe, Antoni Doménech, Isaiah Berlin, Hanna Pitkin, Michael Sandel, o José Luis Villacañas, entre otros. Diversas perspectivas y escuelas de la filosofía política como, por

\footnotetext{
${ }^{29}$ Hankins (2010): 452. La traducción es nuestra. Texto original: "The idea that a republic is the only legitimate form of government and that non-elective monarchy and hereditary political privileges are by definition illegitimate is an artifact of late eighteenth century republicanism, though it has roots in the "godly republics" of the seventeenth century. It presupposes understanding a republic (res publica) to be a non-monarchical form of government".

${ }^{30}$ Hankins (2010): 475. La traducción es nuestra. Texto original: "In the nineteenth century, the older senses of the word republic would drop away, and the modern exclusivist sense of the word as a legitimate government representing the people, contrasted in binary opposition with despotism or tyranny, would come to dominate political discourse. (...) but modern historians of political thought should not forget. At the very least they should be aware that to use the term "republican" uncritically in its modern, exclusivist sense when describing the thought of premodern writers is an invitation to anachronism and historical myopia".
} 
ejemplo, la corriente de la democracia deliberativa, el modelo agonístico de democracia pluralista o la conocida como Escuela de Cambridge han trabajado sobre esta noción de republicanismo, en torno a valores tales como la participación política de la ciudadanía, las virtudes cívicas, el control del uso arbitrario en el ejercicio del poder, el bien común, el comunitarismo, el fortalecimiento de las instituciones, o la libertad como no dependencia ${ }^{31}$.

Pensemos en la situación contemporánea de crisis democrática: en un contexto que podríamos describir como de crisis orgánica de las sociedades neoliberales, de post-democracia y crisis de representatividad, de post-política, de crisis ecológica, de nuevo auge de los autoritarismos, de oligarquización, de asimetría, de patriarcado, así como de cooptación y vaciado de instituciones aparentemente democráticas (las cuales, incluso en nombre de la democracia, y sin más legitimación que el imperio de la Ley, aplican sistemáticamente medidas plenamente antidemocráticas y antipopulares, y que además violan los marcos humanitarios: por ejemplo, la actitud de la Unión Europea o los Estados Unidos ante refugiados y migrantes). En tal contexto, esta vocación de republicanismo surge, por tanto, como reacción, como síntoma, como cristalización, como espejo invertido de las políticas neoliberales desbocadas que han roto el bienestar alcanzado en algunos lugares (a otros nunca les llegó), generado nuevas formas de exclusión e inequidad, y vulnerado los propios principios del republicanismo y del propio liberalismo político. En la reelaboración actual del republicanismo se asume éste como una estrategia para democratizar y refundar las instituciones, así como para recuperar la base comunitaria y su participación política. Ya que éste no es el objeto de esta investigación no nos adentraremos más en ello, sin embargo, sí nos parecía relevante apuntar este fenómeno presente de la recuperación de la tradición política del republicanismo y de sus valores, recuperación acaecida tanto en el ámbito académico como en las agendas políticas de agrupaciones políticas y movimientos sociales.

Dentro de este interés académico por el republicanismo, también se ha dado un interés

\footnotetext{
${ }^{31}$ Como explica Antonio Rivera en una reseña sobre el libro Republicanismo de Maurizio Viroli: «El breve, pero intenso, libro de Viroli repasa algunas de las cuestiones más importantes que centran el actual debate sobre el republicanismo: los conceptos de libertad y virtud cívica, las diferencias y afinidades del republicanismo con el liberalismo y el comunitarismo, el problema de la relación entre verdad y política y el de la religión cívica». Rivera (2002): 205. Viroli (2015). El original en italiano es de 1999. Viroli (1999): Repubblicanesimo. Bari. Ed. Laterza.
} 
por su historia y por su génesis, rubros donde cabría nuestra investigación. Es lo que se ha llamado el giro republicano, que relee fuentes tradicionales en busca de rasgos republicanos y con preguntas de fondo tales como: ¿cómo se llevó a cabo la participación política?, ¿cómo se constituyó la comunidad política y qué se entendía por ésta?, ¿cómo se entendió y legitimó la autoridad?, ¿cómo se pusieron límites al ejercicio de la autoridad?, ¿cómo era la noción de libertad?, ¿quién conformaba el pueblo (las repúblicas)?, ¿cómo se entendía la idea de lo público?, ¿cómo se ejercía la posibilidad de cierta autonomía y "autogobierno” por parte de los cuerpos políticos o corporativos (así municipios, gremios, órdenes religiosas, etc.) dentro de la monarquía?, etc.

Asimismo, incluso, más recientemente se está despertando por fin un interés por la historia y las diversas implementaciones del pensamiento republicano en diferentes contextos más allá del italiano o el anglosajón — por ejemplo el hispánico y el iberoamericano-, lo cual abre un sugerente campo de reflexión e investigación (en el cual quiere inscribirse también esta tesis), permitiendo ampliar las discusiones y reflexiones en torno a este concepto de republicanismo, así como realizar una crítica a las narraciones académicas imperantes acerca de esta tradición política, y con ello nutrirla y complementarla. Dentro de los autores que han contribuido y están contribuyendo a este cometido, pensamos aquí, por ejemplo, en teóricos como John Eliott, Xavier Gil Pujol, José Luis Villacañas, Antonio Rivera, José Antonio Maravall, Anthony Pagden, Víctor Egío, Enrique Marcano, Joan Pao Rubiés, Domingo Centenero, Cirilio Flórez Miguel, Alonso Baelo, Francisco Castilla, Javier Peña, Ramón Ruiz, Annabel Brett, Pablo Fernández Albaladejo, María Martín, Javier López Alós, Rafael Herrera, José María Iñurritegui, George Lomné, Javier Fernández Sebastián, Enrique Marcano, Elías Palti, Gabriel Entin, Francisco Quijano, Tulio Halperin, David Brading, Ambrosio Velasco, José Antonio Aguilar, Rafael Rojas, o François Xavier Guerra, entre otros.

Hemos der ser cautos, sin embargo, y aclarar antes que nada — con el fin de evitar anacronismos - qué entiende esta categoría historiográfica de republicanismo en relación al ámbito epocal de nuestro trabajo. Para ello aquí nos ceñiremos a nuestro contexto de investigación, esto es el pensamiento republicano en los siglos XV y XVI. Pasaremos a continuación a tratar de acortar con la mayor exactitud posible a qué nos referimos al hablar de ello. 
Pese a que lo que vamos a exponer a continuación —a modo de brevísima descripción acerca del concepto de republicanismo y a modo de acotación y clarificación del uso de dicho concepto en el espectro temporal de este trabajo- es seguro de sobra conocido para el lector y sin duda resultará incompleto, hemos preferido elaborar este apunte, aun a riesgo de que parezca demasiado básico. Esto con el fin de lograr las menores ambigüedades y polisemias posibles, aunque conscientes de lo contraproducente que puede ser hacer una descripción tan somera de un concepto tan amplio y ramificado (pues siempre habrá infinidad de carencias en la aproximación que presentemos). Paradójicamente, tal vez sería más efectivo dar por hecho que el lector tendrá un bagaje al respecto, o sea, acerca del pensamiento republicano en el tránsito a la modernidad en Europa, y no entrar en una empresa tan cenagosa, sin embargo, creemos que es útil hacer este apunte $^{32}$. Tampoco metodológicamente podríamos desviarnos aquí en un análisis prolijo del concepto y la historia del republicanismo en los siglos XV y XVI, lo cual, en sí, acapararía varias tesis doctorales.

El concepto de republicanismo es vastísimo y diverso, podríamos decir que viene a representar toda una tradición política, por ello no es un concepto que podamos definir de un modo unívoco, menos incluso teniendo en cuenta, como apuntábamos arriba, el auge reciente y la dispar proyección de los estudios sobre el republicanismo. Maurizio Viroli ha comentado, que Bobbio - quizá con cierta y lúcida ironía - ha llegado a decir que la república es una forma de Estado ideal, un 'modelo moral' que no existe en ningún lugar ${ }^{33}$. Lo que sí podemos, y debemos, hacer aquí es tratar en la medida de lo posible de acotar a qué referirá este término en nuestro trabajo, o sea, a qué nos referimos cuando hablamos de republicanismo en el ámbito de los siglos XV y XVI, cuando aseveramos que el republicanismo es inherente al pensamiento político de ese momento y que es un eje constitutivo de la implementación política de la modernidad temprana. Es decir, intentar aclarar qué denota —y qué connota también — esta etiqueta, la cual es usada para referirse tanto a un ideal político, como a una tradición política, a un modelo normativo, a un programa político, a una praxis política, o a un lenguaje político. Con el fin de ser lo más inteligibles posible, lo que haremos a continuación será una suerte de breve explicación de los

\footnotetext{
${ }^{32}$ No obstante, puede ampliarse información en textos como Pagden (1987) o Coleman (2005).

33 Tomamos este comentario de Gisondi (2016).
} 
rasgos propios del republicanismo renacentista, que es el concerniente a esta investigación. Posteriormente, ya en los siguientes apartados, daremos paso a exponer los aportes académicos de distintos autores relevantes en la historia de la filosofía política sobre republicanismo en la Modernidad temprana, y, asimismo, expondremos diversas críticas a éstos; finalmente, trataremos la cuestión del republicanismo castellano y expondremos nuestra postura.

Como punto de partida hemos de hacer notar que aunque, ciertamente, durante el siglo $\mathrm{XV}$ en Europa hay un desarrollo del republicanismo político, esto no es en absoluto algo exclusivo de este periodo, de hecho lo que aconteció fue una recuperación de los valores republicanos del pensamiento clásico, greco-romano, una recuperación del republicanismo clásico. Y ésta fue catalizada gracias a la labor de traducción y transmisión de los intelectuales, juristas y teólogos medievales. Muchas veces se ha afirmado que esta recuperación del republicanismo clásico en el Renacimiento sucedió casi por sí sola, como ex machina, sin considerar el importante legado medieval que mantuvo y enriqueció esta tradición republicana llevándola hasta el siglo XV, algo con lo que, obviamente, no concordamos.

Cuando hablamos de esta recuperación del republicanismo clásico nos referimos al renovado interés en las teorías políticas de autores como Aristóteles, Cicerón, Salustio, Séneca, Polibio y en el derecho romano ${ }^{34}$. Como tópicos de corte republicano hay que señalar la idea del desarrollo del ideal de virtus a través de la vita activa - frente a la vida meramente contemplativa que tiene como ideal el logro de la virtud a través del conocimiento y la sabiduría- . Una vida activa cuya plenitud se alcanzará mediante el ejercicio del vivere civile, esto es, del vivir civil, mediante la participación en la ciudad, en el ámbito de la república, todo ello en pro del bien común. Esto es, los ciudadanos —identidad propia del hombre en el ámbito republicano - de acuerdo con su naturaleza política han de constituir constituyen una comunidad política sustentada en el ideal de bien común, en saberse depositarios en origen de la potestas y transmisores de ésta al gobernante, en la virtud cívica y en el Derecho. Esto concuerda con el modelo aristotélico, que parte de que la naturaleza del hombre es intrínsecamente política, por ello, como índica Eloy García: «El hombre como ser que tiene una naturaleza política, está dotado de un fundamento cívico a priori que es inherente a su yo real, y al que no puede

\footnotetext{
${ }^{34}$ Sobre fuentes del republicanismo, véase Skinner (2004).
} 
renunciar so pena de ir contra natura: de obrar contra su fundamento originario» ${ }^{35}$. Así lo explica Cirilo Flórez: «Asistimos a la conjunción de la ciudad física con la ciudad moral y civil, de las leyes naturales con las leyes civiles» ${ }^{36}$.

En esta teleología de las virtudes cívicas en aras del bien común, dicha noción de bien común será además el elemento de validación de cuán bueno es el ejercicio político, pues éste ha de aproximarse lo más posible a este ideal del bien colectivo, y si opera en otra dirección, por ejemplo la de los intereses particulares de un gobernante, esto será síntoma de su desviación y corrupción. Esta suerte de filosofía de la acción que promueve el republicanismo, como decimos, se llevará a cabo mediante la participación política.

Como expone J.G.A. Pocock, la teoría de la polis aristotélica fue crucial en esta recuperación republicana, reproducimos esta ilustradora cita suya al respecto ${ }^{37}$ :

Aun así, la objeción estaba clara ¿en qué podía consistir el bien común si llevaba implícita la renuncia a todo bien particular? La contradicción desafiaba la posibilidad de encontrar una solución. Pero el único referente a no perder de vista era que la polity se definía como una relación entre valores, y que el bien de la ciudadanía - gobernar y ser gobernado - consistía en la relación entre la virtud propia de cada uno y la de todos los demás. Era éste el sentido (del carácter mutuo y relacional de la virtud) en que el animal político podía ser considerado verdaderamente un hombre de bien. La teoría de la polis - que era en cierto modo teoría política en su forma original más pura- resultó crucial para la teoría constitucional de las ciudades y para las tesis de los humanistas italianos. (...) De este modo, al abrazar el ideal cívico el humanista cifraba su futuro como persona moral en la salud política de la ciudad, encontrándose obligado a aceptar sin el menor atisbo de cinismo aquel adagio que decía que el ciudadano debía amar su país más que su propia alma.

Al final de este fragmento Pocock menciona también otro elemento muy ligado a esta vocación republicana: el patriotismo, que no hemos de entender tanto en la acepción moderna nacionalista de identidad y defensa del propio país (en el sentido de Estado-nación), sino vinculado, precisamente, a la idea de compromiso y participación con los asuntos de la república.

\footnotetext{
${ }^{35}$ García (2002): 41.

${ }^{36}$ Flórez (2007).

${ }^{37}$ Pocock (2002): 159-160.
} 
Otro de los aspectos fundamentales en torno a los cuales reflexiona el republicanismo en los siglos XV y XVI (aunque, recordemos de nuevo, en esto también continuaba una sólida tradición medieval, sobre todo de la tratadística escolástica a partir del siglo XIII) es la cuestión del origen de la autoridad política. De acuerdo al enfoque republicano, el origen de la autoridad reside, por derecho natural, en la comunidad política, que es quien la transfiere al gobernante. Esta noción del origen popular del poder es otra piedra angular al hablar de republicanismo y la abordaremos ampliamente más adelante. Y dicha noción lleva a la subsiguiente obligación por parte de la comunidad de limitar el uso indiscriminado de la autoridad a quienes ostentan el ejercicio del poder, de evitar su uso arbitrario, para lo cual el gobernante estará sometido a la observancia de la comunidad política. Esta necesidad de controlar y limitar el ejercicio de la autoridad tomó en la modernidad temprana diversas formas: el mantenimiento de lo consuetudinario (esto es, el mantenimiento de usos y costumbres pactadas y reproducidas en la tradición), el constitucionalismo, el parlamentarismo, la elaboración de normas jurídicas positivas, la operatividad de normas jurídicas de corte más metafísico como el derecho natural o el canónico, la capacidad de "autogobierno" de entidades municipales o corporativas, principios como el de la mutua obligación entre gobernante y gobernado, o discursos como el organicismo político o la naturaleza popular del origen de la autoridad, etc.

En relación a esta idea de la limitación en el ejercicio de la autoridad, se presentan como formas destacadas de control el constitucionalismo y el parlamentarismo, que articulados con la monarquía, dan pie a un modelo de gobierno mixto. Cuando hablamos de parlamentarismo, nos referimos a la existencia de instituciones de representación — pensemos en la Cortes, también llamadas Estados Generales, ya de origen medieval y de raigambre estamental o corporativaque regulaban y limitaban la autoridad real, y con las que se pactaban cuestiones fiscales, legislativas, militares, etc. Cuando hablamos de constitucionalismo nos referimos a la existencia de mecanismos jurídicos que garantizasen la preservación del orden jurídico y el reparto del poder entre las diferentes entidades que conformaban el reino, leyes fundamentales (casi podríamos decir que una suerte de "constituciones") a las cuales también tenía que obedecer el gobernante y que no podían ser vulneradas o modificadas sin la aprobación del pueblo, y que referían a asuntos de fondo como la forma de gobierno, la territorialidad o la sucesión. Como veremos en el siguiente capítulo, en relación a esto que hemos esbozado sobre las herramientas 
de limitación de la autoridad, es muy interesante el antecedente del conciliarismo medieval, según el cual la comunidad de la Iglesia, o sea, los fieles, los clérigos y el concilio general poseían más autoridad que el Papa, y la celebración de concilios era un espacio de control al ejercicio del poder del Sumo Pontífice ${ }^{38}$.

Asimismo, en este leve repaso por los elementos más característicos del republicanismo renacentista, hay que detenerse en la cuestión de la concepción de la libertad humana, entendida como no dependencia o no servidumbre (frente al modelo del liberalismo que la comprende más como no interferencia): no podrá ser libre quien esté sometido a un gobierno arbitrario y contrario al bien de la comunidad, que sería un gobernó tiránico. De todos modos, salve decir que la concepción de libertad ligada al Derecho Natural, esto es, entendida como una facultad del hombre, fundada en su razón, de tomar decisiones (que a su vez sean coherentes con los planteamientos y la búsqueda del bien propios del Derecho Natural) operan también. A este elemento de la libertad como no dependencia se le ha dado mucha importancia en la reflexión reciente sobre republicanismo, con contribuciones de importantes teóricos como por ejemplo Quentin Skinner o Philp Pettit ${ }^{39}$. Resume y explica con gran claridad este punto el estudioso Francisco Quijano, de ahí que nos permitamos reproducir una cita tan extensa ${ }^{40}$ :

Sus trabajos [de Skinner y Pettit] parten de la distinción de dos formas históricas de concebir a la libertad política. Por un lado, la liberal, planteada en términos de no interferencia y, por el otro, la republicana o neorromana, entendida como no dependencia (...). Esta otra forma de concebir a la libertad no se presenta en función de la ausencia de impedimentos sino en la posibilidad de vivir fuera de relaciones de dominación. Dicho en otras palabras, un hombre es libre en tanto no esté sujeto a un poder arbitrario (...) Para Skinner, los autores de la Modernidad temprana que recurrieron al concepto de libertad como no dependencia lo hicieron cuando menos en dos ámbitos políticos distintos: el primero remite a las relaciones entre las personas y sus gobernantes; el segundo, al de las comunidades o repúblicas con respecto a poderes externos (...) Por lo tanto, quienes recurrían a dicho concepto no buscaban definir y garantizar los espacios de no intervención de los gobernantes en la vida de las personas, sino encontrar los mecanismos para que la autoridad no se condujera de manera discrecional.

En este somero bosquejo acerca de en qué consistió eso que la filosofía y la historiografía

\footnotetext{
${ }^{38}$ Para más información al respecto, véase Utrera (2005), Alberigo (2004), Rivera (2012).

${ }^{39}$ Con trabajos como Skinner (1999) y Pettit (1997).

${ }^{40}$ Quijano (2017): 46-47.
} 
políticas imperantes han denominado republicanismo en la época que nos ocupa, hay otro factor que éstas han considerado como inherente al republicanismo renacentista y que, por consiguiente, de acuerdo a esta historiografía filosófica imperante, deberíamos exponer también. Este factor es la idea de la irrupción de una filosofía de la historia secular, la cual, de hecho, se ha considerado como otro de los factores fundamentales que definen al republicanismo y que determinan la existencia de éste o no, como si fuera condición sine qua non para poder aseverar la existencia de republicanismo en los albores de la modernidad. Pensamos sobre todo en las visiones de Hans Baron y J.G.A Pocock, en las que nos detendremos en seguida. Nos referimos a la idea de una filosofía de la historia secular y no escatológica, al advenimiento de un tiempo secular en el que el hombre asume su papel central en la historia y en la acción política, ya sin ningún ente trascendente sobre él que lo determine; y es precisamente, según estos académicos, esa auto-asunción secular del hombre de su papel en la historia y en el devenir político el acicate para su participación en la república. Como hemos venido anunciando, no estamos de acuerdo con esta idea, y sostenemos - como una de las tesis de fondo de este trabajo- que es compatible la existencia de ideales políticos republicanos en convivencia con una filosofía de la historia no secular y con la concepción de un tiempo profético, y esta afirmación emana del análisis del caso castellano donde así sucede, y donde, no sólo es que haya un republicanismo en un marco de una filosofía de la historia escatológica, sino que se da una articulación y una retroalimentación entre elementos religiosos y elementos republicanos. Esto lo veremos más adelante. La cuestión aquí es aclarar que, aunque no lo compartamos, desde la academia habitualmente se ha descrito también como uno de los rasgos propios del republicanismo en la primera modernidad esta idea de secularidad.

En concreto éste ha sido uno de los pivotes en torno a los cuales se consolidó la categoría académica de humanismo cívico, que es la que se ha utilizado habitualmente para explicar la encarnación del republicanismo en el periodo que estamos trabajando, con el perjuicio de que se han asimilado, y el término humanismo cívico ha cooptado al de republicanismo. De hecho, en muchas ocasiones, se emplean indistintamente humanismo civico, republicanismo, republicanismo clásico, republicanismo cívico o humanismo político, con la subsiguiente confusión y falta de rigor. Por eso, en el próximo punto vamos a explicar a qué refiere esta categoría de humanismo cívico, casi omnipresente en la academia, y lo haremos ante todo con la 
finalidad de tratar de volver a diferenciar esta categoría de humanismo cívico y la de republicanismo, ya que una nos sirve para nuestro caso de estudio - la de republicanismo- y la otra - humanismo cívico - tal y como está descrita, no. Está claro, como veremos ahora mismo, que lo que se ha descrito como humanismo cívico ha sido entendido como una encarnación del republicanismo para el caso del Quattrocento florentino y que por ello ambas categorías están ligadas, sin embargo, el quid de la cuestión es que el humanismo cívico como ha sido descrito académicamente retoma elementos republicanos, pero no es la única forma en que el republicanismo se materializó en el renacimiento europeo. Esto es, dicho de modo algo pedestre pero claro: en el humanismo cívico hay republicanismo, pero no todo el republicanismo renacentista cabe bajo la etiqueta de humanismo cívico. Naturalmente somos conscientes de la utilidad que esta categoría de humanismo cívico ha supuesto para la historia de la filosofía política y la historia intelectual, y valoramos enormemente sus aportes, el problema, como ya venimos anunciando, es la tendencia en los estudios sobre historia del republicanismo y sobre historia de la filosofía política - sobre todo de la tradición anglosajona - de aseverar que allá donde no se cumplieron con exactitud los rasgos con los que se ha descrito esta etiqueta conceptual de humanismo cívico, no hubo elementos republicanos. Pasemos a ver todo ello en detalle.

\subsubsection{Sobre la categoría humanismo cívico en la historia de la filosofía política. La tesis de Baron, su adopción por Pocock y su estela en la historia del republicanismo.}

Se ha hecho extensiva en las últimas décadas dentro de la historia de la filosofía política la categoría humanismo cívico para aludir paradigmáticamente a lo que fue el pensamiento político y el republicanismo en los siglos XV y XVI en Europa. Como hemos venido apuntando reiteradamente en las páginas previas, en este trabajo problematizaremos el uso extensivo dicha categoría (sin desmerecer su importancia e impronta), pero antes, en este punto, vamos a exponerla; y ya en los dos siguientes puntos abordaremos su crítica. Fue Hans Baron, estudioso alemán emigrado en la posguerra de la II Guerra Mundial a los Estados Unidos y discípulo del historiador, también germano, Felix Gilbert, quien acuñó esta denominación para describir el caso del panorama político del Quattrocento florentino. Esta denominación y la descripción de esta categoría, así como el interés de Baron por el manejo directo de las fuentes, forjaron escuela 
y fueron adoptadas por numerosos estudiosos posteriores para explicar en general la dimensión política del humanismo, y para encontrar en el modelo descrito como humanismo cívico la encarnación de la recuperación de valores republicanos y las raíces del liberalismo político. Entre muchos otros, han empleado esta denominación importantes autores como J.G.A. Pocock, Quentin Skinner o Maurizio Viroli, y en general ésta se ha extendido al hablar del pensamiento político renacentista entendido como preludio de la modernidad política. Como refleja el experto James Hankins, en un justo homenaje a Baron ${ }^{41}$ :

Baron fue seguramente uno de los tres o cuatro intérpretes del Renacimiento más influyentes en la segunda mitad del siglo XX, particularmente en Italia y América, y sus estudios sobre la historia del republicanismo prendieron el resurgimiento del interés en este tema (...) el término "humanismo cívico" es ahora ampliamente utilizado entre los estudiantes de Política, desde la del siglo XV hasta la del siglo XVIII. Su campaña de toda una vida para interpretar textos literarios y filosóficos en su contexto histórico - un método aún inusual en la juventud de Baron - es hoy una práctica normal (y con razón) entre los historiadores intelectuales y los historiadores del pensamiento político.

La primera vez en que Baron empleó este sintagma fue en su trabajo doctoral, presentado en 1928: Leonardo Bruni Aretino. Humanistisch-philosophische Schriftten. Allí acuña el término Bürgerhumanismus, es decir, humanismo cívico. Con posterioridad lo desarrolló ampliamente en sus trabajos de 1955 Crisis of the Early Italian Renaissance: Civic Humanism and Republican Liberty in an Age of Classicism and Tyranny y Humanistic and Political Literature in Venice and Florence at the Beginning of the Quattrocento, sobre todo en el primero, del cual en 1966 presentó una edición revisada; ya al final de su vida, en 1988 revisó de nuevo y amplió la tesis que había elaborado a lo largo de su carrera en una obra compilatoria de su trabajo titulada $I n$ Search of Florentine Civic Humanism. Essays on the Transition from Medieval to Modern Thought ${ }^{42}$. Como el propio Baron explicaba en el libro, En busca del humanismo cívico florentino, su acercamiento inicial al Renacimiento florentino fue más en clave filológica

\footnotetext{
${ }^{41}$ Hankins (1995): 309-310. La traducción es mía. El texto original es: "Baron was surely one of the three or four most influential interpreters of the Renaissance in the second half of the twentieth century, particularly in Italy and America, and his studies of the history of republicanism sparked abroad revival of interest in this topic among students of early modem history; the term "civic humanism" is now as widely used among students of eighteenth as of fifteenth century politics. His lifelong campaign to interpret literary and philosophical texts in their historical setting —a method still unusual in Baron's youth — is today normal practice (and rightly so) among intellectual historians and historians of political thought".

${ }^{42}$ Baron (1955a), (1955b) y (1993), respectivamente, edición esta última traducida al español como: En busca del humanismo cívico florentino. Ensayos sobre el cambio del pensamiento medieval al moderno.
} 
(siguiendo la senda de Paul Oskar Kristeller ${ }^{43}$ ) e interesado en los filósofos neoplatónicos (aunque luego acabara criticándolos por primar lo contemplativo frente a la vida activa y por su interpretación religiosa de pensamiento aristotélico). Sin embargo, Baron se dio cuenta de que el estudio del pensamiento político del Quattrocento florentino estaba más inexplorado y de que éste había sido de enorme importancia. Tuvo el gran mérito de centrarse en la faceta política del pensamiento humanista. Infirió con gran audacia la relevancia e influencia que la recuperación del republicanismo greco-romano, de la teoría política aristotélica y del ideal de vita activa habían tenido en la implementación de la modernidad política, y por ello, a partir de ahí, centró en ello su labor de investigación y trató de poner en valor la estela de lo que había detectado y catalogado como humanismo cívico.

Con humanismo cívico nuestro estudioso se refería al nuevo marco y comportamiento político que aconteció en la ciudad-Estado de Florencia desde principios del siglo XV (en el contexto de su lucha por preservar su autonomía frente al régimen monárquico milanés con pretensiones de expansión), basado en una recuperación del republicanismo clásico, manifestada, de acuerdo a su tesis, en el ideal de vita activa en el ámbito del vivere civile, siguiendo sobre todo a Cicerón - frente al ideal previo de la contemplación y la soledad liderado, según Baron, por Petrarca - en la importancia de la autonomía de las ciudades-Estado (modelo ideal para él, en oposición a la monarquía), en una concepción positiva de la riqueza y en una visión secular de la Historia. Para Baron esta tendencia de pensamiento que fue el humanismo cívico representó un quiebre con la tradición previa, implicando un punto de inflexión en la historia de la filosofía política.

Baron se centró en su célebre Crisis of the Early Italian Renaissance. Civic Humanism and Republican Liberty in an Age of Classicism and Tyranny sobre todo en la figura de Leonardo Bruni, epítome para él del humanismo cívico, y el cual estuvo inspirado en su interés por la vida activa, de acuerdo a lo que expone el académico alemán, por Coluccio Salutati, su antecesor en el cargo de Secretario de la Cancillería de Florencia. A este respecto conviene señalar también la interpretación de otro gran estudioso del periodo, Eugenio Garin, que explica que el ideal político caracterizado por la idea de la libertad en un ámbito de paz de Salutati y Bruni sigue la

\footnotetext{
${ }^{43}$ Kristeller (1993).
} 
senda del Defensor pacis de Marsilio de Padua, que había sido traducido en Florencia en $1363^{44}$. Para Baron Bruni es «el primero en revelar la afinidad entre la ética aristotélica y la conducta de un ciudadano perteneciente a una ciudad-Estado» y «abre el camino a la expresión libre de las actitudes cívicas e, indirectamente, a muchas otras relacionadas con los ideales del Quattrocento», pues lo natural en el hombre es esta pulsión cívica ${ }^{45}$. Recalcar esto último fue importante para nuestro estudioso, ya que para él ejemplarizaba la nueva autoconcepción del humanista cívico (que también se auto-asumía, como veremos en seguida, con un nuevo papel en el devenir de la historia), de ahí afirmaciones de Baron como las siguientes: «La naturaleza — se afirmará ahora [en el Quattrocento] — ha provisto al hombre para la acción, para ser útil a su familia y a sus conciudadanos; la cultura de los humanistas no debe conducir al hombre al aislamiento», o «La acción y el compromiso políticos parecieron representar la única forma verdaderamente humana de vivir» ${ }^{46}$. Se da también como parte de este humanismo cívico, continuamos siguiendo a Baron, un rechazo frontal a la idea de monarquía, según él, Bruni contrapone "imperio" y "república", correspondiendo el primero a los grandes Estados monárquicos que coercitivamente quieren expandirse a costa de otros y la segunda a las pequeñas ciudades-Estado, centradas en la creación de virtus política y que promovían que los ciudadanos participasen en los asuntos públicos ${ }^{47}$.

En general, Baron habla del principio del siglo XV como de una época de corte con la tradición política previa, algo con lo que no coincidimos, pues no puede obviarse la trasmisión y enriquecimiento del legado republicano a lo largo de la Edad Media a cargo de la escolástica; de hecho reconoce el propio Baron la importancia de la tradición de las comunas medievales en esta idea de ciudad-Estado republicana, $\mathrm{y}$, asimismo, reconoce que la idea de vida activa también existió en la Edad Media, aunque opina que siempre estuvo por debajo del ideal de contemplación religiosa ${ }^{48}$. Otro aspecto de ruptura de estos humanistas cívicos que explica Baron, quizá demasiado influido por el liberalismo meritocrático y el capitalismo norteamericanos, fue su aprecio por lo material, su visión favorable de la riqueza y la propiedad en contraste con el ideal moral de paupertas medieval. Según explica, para estos hombres de la

\footnotetext{
${ }^{44}$ Garin (1993).

45 Baron (1993): 196 y Baron (1993): 199.

${ }^{46}$ Baron (1993): 277 y Baron (1993): 409.

${ }^{47}$ Baron (1993): 46.

${ }^{48}$ Baron (1993): 413.
} 
Florencia renacentista la idea riqueza se legitimó al ser ésta interiorizada como un estímulo para el desarrollo de la libertad y la participación política, pues el tener solvencia económica facilitaba la autonomía, y sin condiciones materiales satisfactorias la virtud cívica no se podría desarrollar plenamente ${ }^{49}$. Parece justificar Baron al respecto, que lo que en realidad estaba reñido con el humanismo cívico era el estoicismo de la pobreza y del aislamiento, pues era un estoicismo que promovía alejarse de la vida activa en el espacio civil ${ }^{50}$.

Asimismo, como otro rasgo fundamental de hiato con la cosmovisión previa, el alemán señala el gran cambio que operó en la concepción de la filosofía de la historia de estos humanistas cívicos, los cuales dieron paso a una concepción secular de la misma, en oposición a la concepción escatológica anterior. Explica Baron que hasta muy entrado el Trecento aún se pensaba en un imperio universal ligado a la Iglesia universal y se tenía la idea de que el devenir de la historia aún estaba ligado a la promesa de una salvación futura, y de que, por tanto, la vida histórica estaba supeditada a idea de Providencia, limitando ésta la posibilidad de intervención en la realidad histórica ${ }^{51}$. Sin embargo, el humanismo cívico implicaba una visión causal y secular de la historia, lo cual reposicionaba al hombre como agente con capacidad de intervenir en la historia - ya sin el yugo de la Providencia determinándolo todo - e incentiva su participación política, al tener ya más capacidad de intervención en lo histórico: el ciudadano sería el único hacedor de su destino histórico y político. También a este respecto, es crucial el papel que nuestro académico le otorga a Bruni: «La evidencia definitiva de que una nueva forma de pensamiento histórico se desarrolló en Florencia poco después de 1400, la provee Historiae Florentini Populi, Libri XII [1413] de Leonardo Bruni. Ésta, la primera historia humanista de una ciudad italiana, materializa el humanismo civil de la Florencia de temprano Quattrocento como ninguna otra obra literaria de su tiempo» ${ }^{52}$.

De acuerdo a como veremos más adelante, esta afirmación de una cosmovisión plenamente antropocéntrica nos parece un tremendo anacronismo para el contexto del siglo $\mathrm{XV}$, pero sobre todo nos resulta problemático el que Baron parezca vincular necesariamente la

\footnotetext{
${ }^{49}$ Baron (1993): 193.

${ }^{50}$ Baron (1993): 212.

${ }^{51}$ Baron (1993): 409.

${ }^{52}$ Baron (1993): 44-45. Véase la edición y traducción: History of the Florentine People de Hankins (2001).
} 
motivación a la participación cívica propia del republicanismo a esta suerte de nueva suficiencia de saberse el hombre rector de la historia, pues entendemos que ideales republicanos como la teleología de la virtud cívica, la búsqueda del bien común y la vocación de creación de comunidad política son acicates per se para acometer la participación cívica, sin ser obligatorio el tener un enfoque secular de la filosofía de la historia. Entendemos lo que quiere decir Baron: que esta visión no trascendental de la historia que supuestamente tuvieron los humanistas cívicos contribuyó y estimuló su comportamiento cívico dado que redimensionó su conciencia de capacidad de acción, sin embargo, no pensamos que los ideales republicanos sean inherentemente incompatibles con una filosofía de la historia escatológica. En reflexiones y debates filosóficos actuales sobre la cuestión de la secularidad, sí se suele contraponer lo religioso a la existencia de unos marcos morales normativos laicos que han de operar como superiores a los de las religiones concretas, en el sentido de que estos valores marco - como por ejemplo los Derechos Humanos - dada su universalidad quedarían "por encima” del código moral particular cada religión, en la medida en que serían unos referentes virtuosos válidos, aplicables y exigibles a todos independientemente de su matriz cultural. En cualquier caso, este enfoque contemporáneo de la idea de secularidad no tiene nada que ver con lo que expone Baron, ni tampoco con lo que planteamos nosotros, pues tanto él como nosotros estamos vinculando aquí esta idea de secularidad con la filosofía de la historia, y no con la existencia de normas morales marco ni con otras cuestiones como las de la injerencia de la religión en el gobierno civil.

Tal y como comentábamos al principio de este apartado, la impronta de Baron en la historia de la filosofía política ha sido enorme, sobre todo la adopción del término humanismo cívico, pero ésta tampoco ha devenido una adopción neutra, sino que implica una forma determinada de encarar la historia de la filosofía política y la historia intelectual. Afirma el estudioso Athanasios Moulakis ${ }^{53}$ :

\footnotetext{
${ }^{53}$ Moulakis (2011). La traducción es nuestra, el texto original es: "Its diffusion is closely connected with the 'contextualist school' in the history of ideas. Its original, historically circumscribed meaning was extended to indicate a political language or discourse extending from classical origins to epochal manifestations - 'moments' - in the 'Atlantic republican tradition' (...) the greatest value of the concept has been that of a heuristic device leading to important corrections of received ideas. As such it is itself now subject to serious criticism".
} 
Su difusión está estrechamente relacionada con la "escuela contextualista" en la historia de las ideas. Su significado original e históricamente circunscrito se extendió para indicar un lenguaje o discurso político que se extendía desde los orígenes clásicos hasta las manifestaciones de época — los "momentos"— en la "tradición republicana atlántica" (...) El mayor valor del concepto ha sido el de ser un dispositivo heurístico que conduce a correcciones importantes de algunas ideas recibidas, y como tal, ahora está sujeto a serias críticas.

Veamos ahora a quien recogió más relevantemente el testigo de esta noción acuñada por Baron, esto es, J.G.A Pocock, y ya en el siguiente punto nos asomaremos a esas críticas al concepto de humanismo cívico que menciona Moulakis.

En su famosísima y muy influyente obra El momento maquiavélico (publicado originalmente en 1975 como The Machiavellian Moment. Florentine Political Thought and the Atlentic Republican Tradition), J.G.A. Pocock — parte de la 'Escuela de Cambridge'- elabora un panorama de lo que fue el republicanismo en la Italia de los siglos XV y XVI y lo enlaza con el republicanismo inglés del siglo XVII y con el norteamericano que culminó con la revolución e independencia de los Estados Unidos. Ello lo hace, de acuerdo a su enfoque contextualista y analítico, poniendo énfasis en tener en cuenta los lenguajes políticos y vocabulario propios del momento analizado, emanados de los textos originales, lenguajes que entiende como actos de habla performativos que en sí mismos generan, construyen, realidad política. Uno de lo méritos que se le han reconocido reiteradamente a esta obra es, como expresa Eloy García (quien elabora el estudio preliminar de la edición en español), el hecho novedoso de desligarse de una historia de las ideas abstracta a una historia del discurso, del texto y su contexto histórico; así es su propuesta de releer las fuentes clásicas ${ }^{54}$.

Pocock retomó de Baron tanto la denominación humanismo cívico como sus características para explicar la génesis de la modernidad política en Europa, y para trazar una genealogía del republicanismo atlántico (que, recordemos, no es lo mismo que el discurso liberal-individualista, sino que está más vinculado al comunitarismo) ${ }^{55}$. Como decimos, asumió la tesis de Baron acerca del caso florentino extrapolándola como baremo de lo que supuso la recuperación del republicanismo en el Renacimiento europeo. El estudioso neozelandés dice

\footnotetext{
${ }^{54}$ García (2002): 19.

${ }^{55} \mathrm{Al}$ respecto pueden verse Dagger (2004) y Moulakis (2011).
} 
comprender que haya autores que «hayan llegado a cuestionar si realmente es necesario acudir al concepto de "humanismo cívico" para explicar el origen de la conciencia cívica de la construcción de su discurso», pero opina que «justamente ese lenguaje presenta una parte sustancial del legado que Florencia transmitió a las subsecuentes percepciones política europea y atlántica», legado en el que, según él, encontramos por ejemplo una «impresionante sociología de la libertad», un talante crítico ante la monarquía o una filosofía de la historia secular ${ }^{56}$.

Además de hablar de elementos típicamente republicanos, así la vida activa, la participación, la libertad, el control a la autoridad, etc., el eje al que más relevancia le da Pocock (siguiendo y desarrollando la también la intuición de Baron), es la idea de la irrupción de un tiempo secular (frente al tiempo de lo sagrado), que vincula necesariamente - la hace la condición imprescindible de posibilidad - a la existencia de esta recuperación de ideales republicanos $^{57}$. Para Pocock esta determinada filosofía de la historia es el marco conceptual en el que la doctrina republicana podía consolidarse. De hecho, la noción de "momento", con la que titula su trabajo no la emplea sólo refiriéndose al contexto espacio-temporal, sino a la relación del hombre con la historia, o sea, al hecho de que la cuestión de la participación y el ideal de virtud cívica estaban para estos humanistas cívicos relacionadas con la asunción de su papel en la historia. Sostendrá Pocock que los humanistas florentinos llevan acabo una revolución en los conceptos historiográficos, definitoria para el surgimiento de la mentalidad moderna ${ }^{58}$. Según el estudioso, el ocuparse por lo particular, por las cosas de gobierno, no era compatible con una concepción cristiana de la historia determinada por la Providencia. En esta concepción de la filosofía de la historia escatológica — propia del periodo medieval y del seguimiento del modelo agustiniano de separación entre la ciudad terrena y la Civitas Dei- estima Pocock que toda acción histórica estaba condicionada y supeditada a la escatología, y que la organización de la temporalidad se estructuraba en torno a la promesa de salvación, y que esto neutralizaba un verdadero republicanismo, esto es, aplacaba la importancia y efectividad de la participación en lo político, entendido como participación en lo histórico. En sus palabras: «Mi punto de partida es que la reactivación del ideal republicano por los humanistas cívicos sustituyó el problema de una

\footnotetext{
${ }^{56}$ Pocock (2002): 169 y Pocock (2002): 171.

${ }^{57}$ Pocock (2002) desarrolla ampliamente esta cuestión de la filosofía de la historia secular en las siguientes páginas: de la 77 a la 81, de la 191 a la 209, y de la 85 a la 165.

${ }^{58}$ Pocock (2002): 140 y Pocock (2002): 37.
} 
sociedad para la que la naturaleza política del hombre tal y como la había descrito Aristóteles, debería alcanzar su plenitud en el contexto de una concepción cristiana del tiempo que negaba cualquier posibilidad de realización mundana y secular» ${ }^{59}$. Afirma también ${ }^{60}$ :

El problema estaba en saber si esas dos secuencias independientemente percibidas (historia «sagrada» $\mathrm{y}$ «secular» en el sentido de «profana») podían entrar en una relación de reciprocidad la una con la otra (...) Dios se encontraba de alguna forma presente e implicado en los acontecimientos la historia profana (secular) y los dirigía a los fines de la salvación (...) Pero la construcción de una historia en clave profética no daba lugar a una historiografía concebida en términos autónomos.

En el movimiento de cesura que para nuestro académico implica el humanismo cívico, lo que hará este último es: «abandonar tanto las formas tradicionales de la política como las eternas, para intentar realizar los valores universales de la polis en la forma particular, finita e histórica que era la república» ${ }^{61}$.

De todos modos, pese a lo anterior, Pocock reconoce también que en una concepción del tiempo profética (que es, como veremos más adelante, propia también del pensamiento político converso castellano y de Alonso de Cartagena), una noción como la gracia se politiza y se da una intersección entre lo escatológico y lo político ${ }^{62}$. Asimismo, respecto al tema de la secularización, Riccardo Fubini, quizá entendiendo esta noción más en clave actual, sugiere analizar esta cuestión con más matices y no sólo relacionada con la idea de la filosofía de la historia, pues explica que algunos humanistas, así Lorenzo Valla o Poggio Bracciolini, eran críticos con ciertas tradiciones intelectuales de la Iglesia y compartían enfoques seculares como valorar la experiencia humana como criterio moral más válido que los argumentos teológicos abstractos, pero esto no implicaba que fueran anti-religiosos y tuvieran una cosmovisión laica y secular de la filosofía de la historia ${ }^{63}$.

\footnotetext{
${ }^{59}$ Pocock (2002): 77.

${ }^{60}$ Pocock (2002): 117.

${ }^{61}$ Pocock (2002): 165.

${ }^{62}$ Pocock (2002): 118-120 y 127-128.

${ }^{63}$ Fubini (2003).
} 


\subsubsection{Problemáticas y debates académicos alrededor de esta categoría: diversas críticas al concepto de humanismo cívico.}

Sería osado, además de torpe, negar la tremenda valía de los análisis de Baron y Pocock, pues sus estudios han supuesto grandes aportes a la historia de la filosofía política y a la historia intelectual y han dejado una todavía hoy vívida huella. No lo pretendemos en absoluto, y sin duda reconocemos sus loables contribuciones, sin embargo, esto no quita que haya aspectos muy cuestionables en el trabajo de estos autores en relación a la noción de humanismo cívico; haremos notar a continuación una serie de críticas de otros importantes académicos al respecto.

Dentro de las críticas que se le realizaron a Hans Baron la más inmediata es que su estudio se centra casi únicamente en la figura de Bruni y en el caso del Quattrocento florentino, para de ahí sacar conclusiones generales de lo que implica toda la dimensión política del humanismo. Es más, incluso expertos en El Aretino, como Lucia Gualdo han avisado de que Baron tomó un fragmento pequeño de la obra de Bruni para en base sólo a ello describir todo el pensamiento del autor, lo cual sería un artificio ${ }^{64}$. Además, tal y como apunta Daniel J. Siegel, uno de los primeros críticos a Baron, en el retrato de Baron se idealiza la sociedad florentina de entonces, pues se muestra como una sociedad ya plenamente burguesa e igualitaria, cuando no lo era y mantenía los rasgos feudales y aristocráticos propios de su época ${ }^{65}$. También Siegel, más cercano a la visión filológica del humanismo de Kristeller, en este artículo titulado ya con sospecha “Civic Humanism” or Ciceronian Rethoric?” expresa su desacuerdo con la visión basada en Baron de los humanistas cívicos como teóricos políticos republicanos o como políticos activos, pues para él lo que los caracteriza es su labor como retóricos profesionales, con la laxitud y mudanza de discursos que esto implica ${ }^{66}$. Por su parte Christopher Celenza, en su famoso libro The Lost Italian Renaissance: Humanists, Historians, and Latin's Legacy, denuncia cierto italocentrismo en nuestro estudioso alemán y el sesgo que su peripecia vital implica en su enfoque académico; como resume al respecto Mariana Sverlij ${ }^{67}$ :

\footnotetext{
${ }^{64}$ Gualdo (2005).

${ }^{65}$ Siegel (1966).

${ }^{66}$ Siegel (1966).

${ }^{67}$ Celenza (2004) y Sverlij (2013): 30.
} 
Desde la perspectiva de Celenza la tesis de Baron es fácil de definir: con una exagerada concentración en un hecho histórico (la amenaza Viscontea sobre Florencia) Baron intenta dar cuenta de la emergencia de los orígenes positivos de la modernidad, concentrados en la idea de República. Como los filósofos escolásticos criticados por los humanistas, Baron estaría desvirtuando los textos que tiene delante, asimilándolos a su propio contexto histórico: la caída de la república de Weimar y el posterior horror del nazismo que barre con toda idea republicana. Es por ello que, para Celenza, resulta central la gran acogida que la tesis de Baron tiene en las academias norteamericanas.

Otro académico que ha rebatido bastante a Baron, sin dejar de apreciar su mérito, es James Hankins, que lo cuestiona por varios flancos ${ }^{68}$. Primeramente estima problemática su visión del individualismo en el Renacimiento por considerarla anacrónica y trasladada de nociones de subjetividad ya propias del siglo XX, asimismo, asevera que los más recientes estudios sobre Bruni, así los de Fubini o Cabrini, lo muestran en realidad como un defensor de posturas oligárquicas. Coincide Hankins con Siegel en la idea de que estos humanistas cívicos como Salutati o Bruni eran retóricos profesionales a los que se contrataba por elaborar propaganda - de ahí el que no siempre pueda ser identificado lo que escriben con sus propias opiniones y el que pueda haber aparentes contradicciones entre sus discursos- y no tenían, por consiguiente, un férreo compromiso sólo con una posición política ${ }^{69}$. Señala también este profesor estadounidense la errónea tendencia a universalizar a otros contextos lo que Baron expuso para el florentino y a pensar que el republicanismo emana de la Florencia del siglo XV, sin recordar que éste viene de la Antigüedad: «En efecto, gran parte de los eruditos sobre el humanismo (...) han señalado la universalidad de temas que Baron conectó con la experiencia política de Florencia (...) Si continuamos usando el término "humanista cívico", debería reconocerse claramente que el intento de reformar y revalorizar la vida de la ciudad-estado es de acuerdo con modelos de la Antigüedad (...) el "humanismo cívico" no es florentino, sino romano» ${ }^{70}$.

Sin embargo, los puntos que más nos interesa reseñar de la crítica de Hankins a Baron y

\footnotetext{
${ }^{68}$ Hankins (1995) (1998) (2010).

${ }^{69}$ Hankins (1995): 310, 320 y 326.

${ }^{70}$ Hankins (1995): 330. La traducción es nuestra. El texto original es: "Indeed, much of the scholarship on humanism (...) has pointed out the universality of the themes Baron connected with the political experience of Florence. If we continue to use the term "civic humanist," it should be clearly recognized that the attempt to reform and revalorize the life of the city-state in accordance with ancient models (...) "Civic humanism" is not Florentine, but Roman".
} 
los cuales compartimos plenamente - como hemos venido apuntando teniendo en cuenta el caso castellano - son dos. Por un lado está la incorrecta y restrictiva asimilación humanismo cívico $=$ republicanismo, identificación que, como bien indica Hankins, obliga a replantearse el uso indiscriminado de esta categoría de humanismo cívico. Reproducimos sus palabras: «La segunda razón por la cual la nueva imagen de Bruni importa es porque significa que toda la categoría del "humanismo cívico" necesita ser repensada, o descartada por completo (...)» ${ }^{71}$. Por otro lado, está la advertencia de Hankins de lo equivocado de afirmar — como hace Baron — que no pueden darse rasgos del republicanismo bajo una forma de gobierno señorial (recordemos lo visto en el punto 1.3.1). Menciona Hankins el caso de Uberto Decembrio, quien promovió el republicanismo y fue defensor de la institución monárquica a la vez (no es casualidad, como veremos en la segunda parte de esta tesis, que nuestro autor de estudio, Alonso de Cartagena, tuviese una sólida relación con su hijo Pier Candido Decembrio); así expresa su idea Hankins ${ }^{72}$ :

El cambio que Baron observó en el carácter del humanismo entre las generaciones de Petrarca y de Bruni (...) lo encontramos no sólo en Florencia y Venecia, sino también en toda Italia, tanto en los regímenes señoriales como en las repúblicas. Consideremos, a modo de comparación, el De re publica de Uberto Decembrio (...) para Uberto, al igual que para los llamados "humanistas cívicos", el bien común urbano es propio de la naturaleza, surgido de la necesidad mutua y basado en la justicia. Todos deben ser tratados igualmente bajo la ley (...) El secreto de una república feliz consiste en que su príncipe, sus hombres principales y sus ciudadanos posean y ejerzan las virtudes clásicas.

En sintonía con esto último se articula la revisión del profesor italiano Guido Cappelli a la tesis de Baron $^{73}$. Opina que detrás de esta categoría hay una lectura un tanto reduccionista de la recuperación del republicanismo clásico en el Renacimiento italiano, pues dicha lectura se centra demasiado en una crítica a la monarquía, a la cual se tilda de autoritaria y tiránica per se sin entenderla en toda su profundidad. Es decir, sin contemplar una noción fundamental en los

\footnotetext{
${ }^{71}$ Hankins (1995): 327. La traducción es nuestra. El texto original es: "The second reason why the new picture of Bruni matters is because it means that the whole category of "civic humanism" needs to be rethought either discarded entirely (...)".

${ }^{72}$ Hankins (1995): 328-329. La traducción es nuestra. El texto original es: "The change Baron observed in the caracter of humanism between the generations of Petrarch and of Bruni (...) we found not only in Florence and Venice, but through out Italy, in signorial regimes as well as in republics. Consider, by way of comparison, the $D e$ re publica of Uberto Decembrio (...) For Uberto, as for the so called "civic humanists," the urban Commonwealth is a product of nature, arising from mutual need, and based upon justice. Everyone should be treated equally undert he law (...) The secret of a happy republic consists in its prince, its leading men, and its citizens possessing and exercising the classical virtues".

${ }^{73}$ Cappelli (2006) (2009) (2011) (2014).
} 
albores de la modernidad como es el organicismo monárquico y los aspectos derivados de él, muchos de los cuales no son excluyentes con valores del republicanismo clásico, sino todo lo contrario, pues están de acuerdo con la idea de que el origen de la autoridad es transferida de la comunidad política al monarca, y se conforman como mecanismos de control contra el uso indiscriminado de esta autoridad. Nos referimos a aspectos tales como la unión y sinécdoque prínceps-pueblo (ambos ligados indivisiblemente al formar parte de un mismo cuerpo en el cual el monarca es cabeza dirigente), el principio de mutua obligación, la relación rey-pueblo basada en el amor frente al timor, la virtus real orientada al bien común como baremo del ejercicio del poder, la figura de la expectatio ante la actitud del rey como forma de control frente a la tiranía, la "impersonalidad" del Estado vía la asimilación ley-rey-Estado — posible gracias a esta superposición organicista - o la idea de ejemplaridad del gobernante ${ }^{74}$. Asimismo, Cappelli ha hallado anacronismos en la compresión de Baron del pensamiento político humanista al interpretar la vocación del vivere civile de entonces bajo categorías de democratización, participación, representatividad, contractualismo, y republicanismo posteriores; ha aseverado también Cappelli que esta denominación de humanismo cívico se ha orientado interesadamente para reconstruir y legitimar el modelo político del liberalismo político anglosajón ${ }^{75}$. De todos modos, por nuestra parte, no creemos tampoco que detrás de quienes hablan de humanismo cívico haya una intención, al menos deliberada, de conformar una narrativa legitimadora, casi imperialista, del buen liberalismo anglosajón ${ }^{76}$. En cualquier caso, por todo ello, y para desmarcarse de lo que él considera un constructo académico para justificar un relato sacralizado del liberalismo atlántico — constructo que además rechaza a priori la posibilidad de convivencia entre monarquía y valores republicanos, vía el organicismo- Guido Cappelli, propone con tino denominar a este pensamiento político humanista humanismo político frente a la denominación habitual de humanismo cívico ${ }^{77}$.

Este humanismo político del que habla dicho profesor italiano no sería necesariamente antimonárquico, e incluiría también elementos republicanos, pues la recuperación de estos valores fue algo trasversal a aquel momento y no sólo aconteció en Florencia bajo el modelo de

\footnotetext{
${ }^{74}$ Cappelli (2009).

${ }^{75}$ Cappelli (2006) (2011).

${ }^{76} \mathrm{Si}$ siguiéramos una crítica en esa dirección, podríamos, llegar a entender así, incluso textos como Sobre la revolución de Hannah Arendt. Arendt (2006) .

${ }^{77}$ Cappelli (2011): 4.
} 
las ciudades-Estado autónomas. Tal vez éstas fueran su máxima expresión, pero no la única. Otros modelos también tomaron elementos del republicanismo clásico, pero sin romper necesariamente con la toda la tradición y cosmovisión previa.

Todavía en vida, Baron fue consciente de algunas de las críticas que se le hicieron, por ello, en su En busca del humanismo cívico florentino hace una especie de alegato en defensa de su trabajo. Expone ${ }^{78}$ :

No fue mi intención en la Crisis declarar que todos los estudios anteriores sobre el Renacimiento estaban equivocados, sino que simplemente no eran lo suficientemente amplios. (...) Más bien, el problema fundamental fue si la retórica y la nueva filología constituyeron las únicas contribuciones humanistas, o incluso las principales, en la formación del espíritu moderno; si el humanismo pudo haber desempeñado su papel fundamental en los siglos XV y XVI de no haber ofrecido también una visión nueva de la naturaleza y de la historia del hombre y una apreciación novedosa de los valores humanos. La Crisis intenta demostrar cómo los humanistas florentinos del Quattrocento no fueron sólo los continuadores de la tradición retórica y quienes contribuyeron inicialmente a la formación de la filología nueva, si no que dieron también origen a la filosofía de la vida política activa y a la secularización de la idea de la historia y la cultura, los dos leit motiv de la escuela de pensamiento que es analizada en la Crisis.

Respondió, asimismo, Baron a quienes le acusaban de defender una transformación demasiado súbita en el Quattrocento, que él no la describió como abrupta, y que siempre explicó que la génesis de lo que sucedió en el siglo XV venía tejiéndose ya en el Trecento. Sin embargo, con un regusto de rechazo a lo medieval y con su habitual tono laudatorio y entusiasta ante el Quattrocento florentino, matizaba Baron $^{79}$ :

Ya se habían hecho a lo largo del Trecento descubrimientos de importancia dentro del pensamiento antiguo y en la política de la historia - incluyendo las ideas Cicerón sobre la Vita activa política y el papel histórico desempeñado por la Respública romana-, mas habían estado en desacuerdo considerable con el cambio de la mentalidad medieval, de modo que fueron nuevamente descartados o neutralizados. Después de 1402 la república florentina pareció haber reencarnado el espíritu que animó a Atenas y Roma. La imagen histórica de la Respública romana ascendió, finalmente, al foro y el ciudadano romano Cicerón, liberado de sus disfraces medievales, se convirtió en el modelo de los humanistas cívicos.

\footnotetext{
${ }_{78}^{78}$ Baron (1993): 413-414.

${ }^{79}$ Baron (1993): 420.
} 
A este respecto del reconocimiento de la herencia medieval, indica José Luis Villacañas en relación con los aportes de Quentin Skinner a la historia del republicanismo ${ }^{80}$ :

A él debemos importantes contribuciones sobre ambos asuntos: los métodos en que los cambios de retórica nos permiten apreciar los cambios de pensamiento y de percepción de la realidad, y la forma en que se mantuvieron las tradiciones republicanas en toda Europa como un legado compartido. Skinner no ha observado con suficiente atención las raíces medievales del republicanismo. En este sentido debe ser complementado por autores como Janet Coleman o Cesare Vasoli (...) La enseñanza que extraigo de estos breves comentarios es que determinadas tradiciones, como el republicanismo, se abordan mejor cuando se observan en la totalidad de su despliegue histórico.

Con respecto a J.G.A. Pocock, es de sobra sabida la fabulosa recepción que su obra The Machiavellian Moment (publicada en 1975) tuvo en la academia anglosajona y su rol fundamental en la historia del republicanismo, sin embargo, no estuvo tan bien vista entre los intelectuales italianos de los años ochenta, pues se leyó como un texto de proselitismo del republicanismo atlantista, como denunciaron por ejemplo Cesare Vasoli o Renzo Pecchioli (aunque su visión se restauró en los noventa, sobre todo gracias a Maurizio Viroli) ${ }^{81}$. Y, en efecto, es verdad que nos encontramos ante la circunstancia - tras el éxito del libro de Pocockde cierto abuso del sintagma humanismo cívico para el caso anglosajón, esto es, para explicar sus avatares políticos entre los siglos XVII y XIX (o sea, la historia del llamado republicanismo atlántico), con el subsiguiente malentendido de que ya la idea de humanismo cívico-y por ende la de republicanismo, dada la asimilación entre ambos que ya hemos hecho notar varias veces, criticada también por ejemplo por Frank Lovett— se asocia casi en exclusiva a este espacio, excluyendo por tanto a otros ámbitos ${ }^{82}$. Este inconveniente lo han subrayado estudiosos como, por ejemplo, Daniel Rodgers, que analiza la trayectoria de concepto republicanismo o Elías Palti, que trabaja sobre la genealogía de lo político en el ámbito hispánico ${ }^{83}$. Athanasius Moulakis por su parte alerta del riesgo de que este uso excesivo y generalizado de la categoría historiográfica humanismo cívico lo aleje de su matriz histórica: «Además, existe un peligro real de que la fuerza ideológica que el humanismo cívico haya adquirido como un término de moda, pueda

\footnotetext{
${ }^{80}$ Villacañas (2017): 2.

${ }^{81}$ Vasoli (1979), Pecchioli (1983 y 1986). Viroli (2000) (1992) (2015).

${ }^{82}$ Lovett (2016).

${ }^{83}$ Rodgers (1992) y Palti (2012).
} 
desbordar los fundamentos históricos sobre los que descansa el concepto. Esto es particularmente crítico para un término que extrae gran parte de su fuerza de la afirmación de estar enraizado en antecedentes históricos vividos» ${ }^{84}$.

Aparte de esto, en la cuestiones en la que más nos interesa incidir, por ser en las que fundamentalmente discrepamos con Pocock son las siguientes:

1) La esencial vinculación que hace Pocock entre republicanismo y filosofía de la historia secular, excluyendo por ello de la posibilidad de participar del republicanismo a los pensadores que posean una concepción escatológica de la filosofía de la historia y presuponiendo que toda escolástica es ahistórica y ajena a los ideales cívicos.

2) La identificación entre republicanismo y humanismo cívico, generalizada tras el trabajo de Pocock y las interpretaciones de éste.

3) El rechazo de Pocock a la idea de que se desarrollase republicanismo en el ámbito hispánico. A este respecto asevera el estudioso (sin mayor explicación para una afirmación tan rotunda y extrema, y del todo equivocada desde nuestro punto de vista) en su introducción a la traducción al español de su célebre obra ${ }^{85}$ :

Los estudiosos españoles percibirán con toda claridad que no se ocupa del maquiavelismo de sus grandes escritores del XVI - de su siglo de oro-. Y es que esa rama del pensamiento que en su mayoría fue antimaquiavélica, estuvo relacionada con la razón de estado de la gran monarquía territorial expansiva y no consideró al ideal de república como una alternativa en condiciones de oponerle frente. El autor - con acierto o sin élha encontrado pocos rastros del republicanismo clásico en el pensamiento español moderno, y cree que en España la república ha sido un fenómeno privativo de los siglos XIX y XX.

\footnotetext{
${ }^{84}$ Moulakis (2011). La traducción es nuestra. El texto original es: "There is furthermore a real danger that the ideological force civic humanism has acquired as a buzzword may overwhelm the historical foundations on which the concept rests. This is particularly critical for a term that draws a great deal of its strength from its claim to be rooted in lived historical antecedents".

${ }^{85}$ Pocock (2002): 75.
} 
Y discrepamos en estas cuestiones porque las refuta nuestro caso de estudio, la Castilla del siglo $\mathrm{XV}$, donde, de acuerdo a lo queremos demostrar, sí hubo republicanismo. Lo argumentaremos, y explicaremos las particularidades de este republicanismo, considerando el contexto filosófico, político y socio-cultural castellano —que veremos en el capítulo dos- y deteniéndonos en la figura de Alonso de Cartagena, concretamente en su Defensorium Unitatis Christianae - que veremos en los capítulos tres y cuatro-. Y sí se dio pensamiento político republicano — aunque con esto no estamos aseverando que fuese la única posición política o lenguaje político existente- "pese" a varias circunstancias que, según Baron y Pocock, lo imposibilitarían. Circunstancias como las siguientes:

A) Que este republicanismo fue desarrollado por teólogos y juristas escolásticos cristianos - conversos, para más detalle - con una filosofía de la historia escatológica y profética, y no secular.

B) Que era un republicanismo compatible con la idea de monarquía (que tenía en cuenta el modelo de gobierno mixto, el discurso organicista, y mecanismos de control al ejercicio de la autoridad como el constitucionalismo y el parlamentarismo)

C) Que elementos religiosos — como universalidad la de la gracia, o de la revelaciónno sólo es que fueran compatibles con elementos republicanos como la participación, la igualdad o la inclusión, sino que se articularon con éstos e incluso los redimensionaron.

No que es que se diese un republicanismo en Castilla "pese" a estas circunstancias, sino que estas circunstancias (entre otras propias del contexto castellano que, como decimos, analizaremos en el capítulo segundo) lo catalizaron y determinaron sus características, que no es que fueran mejores, ni peores, ni menos puras, ni menos "republicanas" que las del caso florentino. Simplemente fue otra la forma de implementación del republicanismo.

Por ello, podemos sacar la conclusión de que el humanismo cívico (tal y como ha sido definida esta categoría académica) no es aplicable al caso castellano. Y también sacar otra conclusión resultante de la primera: el humanismo cívico no fue el único que se hizo cargo de los 
postulados republicanos en la Europa de los siglos XV y XVI. Por consiguiente, esta categoría historiográfica no debería tener la patente de corso para erigirse en clave de lo que implica la existencia de republicanismo en tal periodo, ni tampoco para erigirse baremo de la existencia o no de Modernidad política. Teniendo todo ello en cuenta, deberíamos ser en esto implacables y no aceptar la asimilación restrictiva: humanismo cívico $=$ republicanismo.

Coincidimos plenamente en nuestras críticas a Pocock con las que apunta Francisco Quijano en su trabajo Las repúblicas de la monarquía. Pensamiento constitucionalista y republicano en Nueva España 1550-1610, libro en el que reivindica la particular implementación del republicanismo en la Nueva España de los siglos XVII y XVII, y en el que defiende cómo en este ámbito, pensadores hispanoamericanos como Alonso de la Veracruz, Bartolomé de Las Casas y Juan Zapata Sandoval —influidos por la Segunda Escolástica española - promovieron el republicanismo, y cómo éste y el constitucionalismo acontecen en la relación de las diversas comunidades políticas con la monarquía dentro del ámbito de la monarquía hispánica ${ }^{86}$. Pues bien, así expone este estudioso su crítica a Pocock ${ }^{87}$ :

Como se mencionó, para Pocock, una de las características centrales de la tradición republicana es la irrupción de la temporalidad en la concepción del ser humano dentro de la historia: este presupuesto se habría construido en oposición a la forma en que la escolástica abordaba dicho problema. Por ello, un espacio como el hispánico, en donde el escolasticismo dominó en gran medida el ámbito intelectual, quedaba por definición excluido del "momento maquiavélico", sin importar que un buen número de pensadores utilizara argumentos muy semejantes a los considerados dentro del republicanismo italiano e inglés. En última instancia, detrás de esta valoración, me parce, se encuentra la identificación que se tiende a establecer entre republicanismo clásico y humanismo cívico, identificación con la que estoy en desacuerdo. (...) Asimismo, caracterizar a toda la escolástica como una forma de pensamiento ahistórica y especulativa puede resultar un movimiento simplificador.

Con estos últimos párrafos ya nos vamos adentrando en el ámbito hispánico, a donde queríamos llegar y en base al cual se ha basado nuestra problematización del uso del término humanismo cívico. Demos paso ahora al siguiente apartado en el que propondremos, entonces, una denominación alternativa para nuestro caso de estudio.

\footnotetext{
${ }^{86}$ Quijano (2017).

${ }^{87}$ Quijano (2017): 56-57.
} 


\subsubsection{Nuestra propuesta de denominación para el caso castellano: pensamiento político converso.}

Tal y como hemos expuesto en el punto previo, más que problematizar per se esta descripción de lo que fue el humanismo cívico florentino, lo que hemos venido queriendo señalar es que se han extrapolado e hipostasiado las características descritas para el mismo, y en base a ello se ha descrito, uniformándolo y reduciéndolo, el republicanismo europeo de la modernidad temprana. Bajo este rubro de humanismo cívico se trazó una línea, a modo de genealogía, desde el humanismo cívico al republicanismo atlántico del XVIII, quizá en una suerte de búsqueda del origen de éste en pos de una narrativa legitimadora (aunque entrar en ello no es el objetivo de este trabajo). El problema es que esta asimilación de humanismo cívico con republicanismo, y a su vez, en otro pliegue de asimilación, la identificación de republicanismo con republicanismo atlántico ha implicado un enfoque restrictivo de lo que implica la noción de republicanismo, y, para mayor distorsión de las cosas, estas asimilaciones no son inofensivas, sino que entrañan un sesgo valorativo: es como si el "verdadero" republicanismo renacentista, el "válido", fuera el que coincide al cien por cien con lo descrito por la academia para el humanismo cívico, como si no cupiese republicanismo en otros lenguajes políticos del XV, como la escolástica por ejemplo, o en otras concepciones de la filosofía de la historia no seculares, como si allá donde se comparten algunos rasgos de lo expuesto para el humanismo cívico pero no todos, no pudiera haber republicanismo.

Nos explicamos: sin duda, los aportes de estos estudiosos como Baron o Pocock a la historia del republicanismo son importantísimos, sea dicho esto de antemano, pero pensamos que tienen el problema de base de no contemplar otras formas que tomó en la Europa de los siglos XV y XVI, más allá de la florentina, además no se explica por qué este modelo florentino ha tenido que devenir paradigmático. Obviamente, esto no sería un inconveniente si se habla sólo del caso florentino o italiano, pero la asimilación de que pensamiento político en la transición a la Modernidad es igual, o debería serlo, al modelo florentino, esto es, extrapolarlo - y además como lo deseable - nos parece inadecuado. Y ésta parece ser la deriva que ha tomado la historia de las ideas y del pensamiento político al abordar este periodo: se presupone que el humanismo 
cívico es la encarnación del republicanismo en el cuatrocientos. Y que se ha de participar en lo que se han presentado como rasgos propios de este humanismo cívico para que otras formas de diseñar e implementar el pensamiento político en el cuatrocientos europeo, puedan considerarse como "pensamiento político republicano" y como "precursoras" de la Modernidad política. Es decir, la academia ha parecido asumir que sólo bajo la categoría humanismo cívico - modelo que queda descrito extrapolando las características del caso florentino- se desarrollaron valores republicanos en el siglo XV (aseveración que parece implicar, además, con qué realidades sociopolíticas y teológico-filosóficas supuestamente estos valores son compatibles o incompatibles), y que fuera de éste humanismo cívico no cabe republicanismo. Ha parecido asumir también que sin paso a una filosofía de la historia secular no puede haber modernidad filosófica ni política, lo cual implica una visión bastante restrictiva y hegemónica de lo que es la modernidad, aunque esto es entrar ya en otro gran debate.

Opinamos que estas conclusiones son un salto al vacío con el que no concordamos y que, por ello, pretendemos desmontar, pues en nuestro caso de estudio, la Castilla del XV sostenemos que sí hubo pensamiento y praxis republicana, pero con algunas características muy diferentes a lo descrito bajo el rubro humanismo cívico (otras, sin embargo, las comparte), y no por ello el republicanismo castellano hubo de ser menos válido o ha de ser menos considerado como tal republicanismo. En lo que hemos denominado pensamiento político converso, hay sobre todo tres elementos de distancia con la categoría humanismo civico tal y como se ha descrito. Éstos elementos que sí son inherentes al pensamiento político converso y que, sin embargo, erróneamente, se han planteado como incompatibles con la recuperación de valores republicanos, son: i) la escolástica y la herencia medieval, ii) la defensa de la institución monarquía y iii) la visión escatológica de la filosofía de la historia.

i) Respecto a lo primero, no estamos de acuerdo con el rechazo casi sistemático a lo medieval y con comprender al Renacimiento como fenómeno ex novo. Entendemos que la teoría política de corte republicana propia del Renacimiento se heredó de la Edad Media, pues en ésta los conceptos políticos republicanos de la Antigüedad habían seguido operando y se habían enriquecido. Por ejemplo: es imposible entender el corporativismo intrínseco al republicanismo 
renacentista sin tener en cuenta las reflexiones jurídicas hechas al respecto en el medievo (en torno al Derecho Romano o a los cuerpos de derecho canónico); ya sea para contribuir a un corporativismo en su vertiente urbana y gremial, ya sea en su vertiente organicista y espiritual. Tampoco puede omitirse la impronta del parlamentarismo (o pactismo) y el conciliarismo medievales. No sería intelectualmente adecuado, ni justo, seguir hablando, como tantas veces se ha hecho en la historia de las ideas de la Edad Media como un páramo embrutecido y del Renacimiento como un movimiento cultural descastado, sin filiaciones, que llega ex nihilo. Si bien el humanismo puede reivindicar nuevas praxis - tanto con cambios formales en lo filológico, como con nuevas formas de participación en lo político- e, incluso, si bien el proyecto Renacentista, sobre todo en Italia, se quiere ver a sí mismo y se presenta como una ruptura con el pasado inmediato medieval, que juzga como opaco y bárbaro, esto no obsta para que su caldo de cultivo y sus insumos intelectuales estuvieran en el arsenal de ideas transmitidas y repensadas en la Edad Media. Fue el intelectual escolástico medieval de corte tomista, fueron los teólogos y juristas medievales los guardianes de esta transmisión republicana, y además la complementaron ${ }^{88}$. Por ello no compartimos que la definición de humanismo cívico que vimos en el punto 1.3.2 muestra a este programa político, y su republicanismo propio, como necesariamente opuesto al escolástico.

Además, ese acusar de un humanismo "no tan puro" como se hizo desde el Norte de Europa a lo peninsular, dada su mistura con la impronta medieval árabo-semítica, es, a nuestro parecer, un gran error, pues el racionalismo y aristotelismo de autores como Averroes o Maimónides no alejan de lo republicano, más bien al contrario, y los conversos peninsulares son vitales en dicho republicanismo ibérico.

En el caso castellano - y en todo el llamado Mundo Hispánico- ya no sólo en

\footnotetext{
${ }^{88}$ Tomo el uso del término aquí de Alain de Libera. Acerca del papel del intelectual medieval en Europa y su herencia árabo-semítica es bien interesante su obra: Libera (2000) Pensar en la Edad Media.
} 
la Edad Media, sino durante los siglos XV, XVI y XVII siguió vigente la escolástica, pero no toda, ni mucho menos (como vimos antes), estaba a favor de discursos como la razón de Estado o el absolutismo. Conste también otra enorme contribución que los escolásticos de este periodo: tal y como señala Francisco Quijano respecto a los juristas y canonistas de principios de la modernidad «Su reflexión, desde el método escolástico, fue fundamental para dilucidar el sentido de términos como ius, lex, dominium, imperium, iurisdictio, auctoritas, potestas civilis, potestas ecclesiastica, respublica y una larga lista que llenan las páginas de los tratados escolásticos - y no escolásticos- de la época»; además, indica este estudioso, «(...) se enriqueció su contenido [el de estos vocablos] a través de hacer evidentes los problemas relativos a sus usos» ${ }^{89}$. Esta aclaración y actualización del vocabulario político y jurídico de su tiempo se consolidaría.

ii) Sobre la segunda cuestión de la monarquía, retomamos lo explicado en el punto previo - recordemos las críticas de James Hankins, Guido Cappelli o Antonio Rivera- acerca de la perfecta compatibilidad entre elementos republicanos y monarquía bajo el formato de gobierno mixto con sus intrínsecos parlamentarismo y constitucionalismo y bajo modelos teóricos como el organicismo ${ }^{90}$. Además, como hemos venido apuntando, la escolástica castellana, en lo referente a la cuestión del origen de la autoridad del poder político (también denominada como dominio), sostuvo y defendió que ésta, por Derecho Natural, es transferida a la comunidad política directamente de Dios y que, a su vez, es la comunidad quien se la transfiere al gobernante (en este caso el monarca). Es cierto, que existía la limitación de que una vez hecha esta transferencia, la comunidad política perdía ya prácticamente todo el dominio y cedía la autoridad sobre sí (algo que ya sólo podría revocar legítimamente en casos extremos como aquéllos en los que fuera pertinente un tiranicidio, cuando el gobernante gobernase contra el bien común y el derecho natural), aunque

\footnotetext{
${ }^{89}$ Quijano (2017): 78.

${ }^{90}$ Hankins (2010), Cappelli (2006) (2009) (2011) (2014), Rivera (2002).
} 
también es cierto que dentro de la escolástica hispánica, sobre todo de la de la Segunda Escolástica o Escuela de Salamanca y sus seguidores americanos, sí se contemplan grados y matices en cuanto a esta cuestión del dominio y se empieza a introducir la idea de que en la transferencia inicial de autoridad de la comunidad al gobernante esta transferencia no implicaría que la comunidad perdiese toda la potestad sobre su dominio, lo cual le permitiría seguir opinando sobre decisiones políticas que le atañen y poner límites a la autoridad del gobernante, si ésta atentaba contra la voluntad común, mediante diversos mecanismos (los propios constitucionales y pactistas propios de un gobierno mixto).

En lo concerniente a que pudiera entenderse al monarca como vicario de Cristo, o a su concepción providencialista y profética, esto no implica para nada que se comparta un enfoque teocrático, que sería incompatible con lo anterior. Como veremos con detalle en el capítulo segundo - y seguimos en ello a Antonio Rivera - en cuanto a la idea de la potentia Dei, omnipotencia divina, como forma de argumentar la defensa de la monarquía, no hay que confundir el modelo medieval —en el cual la diferencia entre potentia absoluta y potencia ordinata permite argumentar en pro de la limitación del poder temporal del monarca, y en el que no se contempla la transferencia de potentia Dei al monarca; modelo que opera en la escolástica castellana — y el modelo moderno o absolutista, que no distingue entre estos dos tipos de potencia y entiende tanto el poder divino como el temporal como absolutos, más en la línea de Hobbes, y apoyando la postura teocrática en la que la transferencia fue otorgada al soberano directamente de Dios ${ }^{91}$. Hablaremos también más adelante sobre la idea del monarca como defensor pacis, garante y defensor de la paz propia de un orden natural preexistente, pero de nuevo hemos de aclarar que esto no implica un enfoque teocrático ni absolutista de la monarquía. Considerando todo lo anterior, por consiguiente, incidimos en la plena compatibilidad

${ }^{91}$ Rivera (2001): 171 y Kantorowicz (1985). 
entre recuperación de valores republicanos y defensa de la institución monárquica, teniendo en cuenta el contexto que nos ocupa.

Estimamos la cuestión de la crítica a la monarquía no ha de verse como requisito obligado al hablar de recuperación renacentista del republicanismo clásico, pues, sí así fuese, no podría explicarse el pensamiento político castellano, donde la monarquía apenas se cuestiona y es posible el encaje de la tríada 'vivir civil-monarquía-patriotismo'. Y donde el específico enfoque de la monarquía acarreó muchos aportes en nociones como las de servicio público, virtud, ejemplaridad, o sujeción al derecho - en línea con la tradición de las Partidas de Alfonso X-. Todo ello, como decimos, lo desarrollaremos con detalle en el capítulo segundo, donde también matizaremos la diferencia entre un monarca teocrático y absolutista y un rey sometido al Derecho y a las Cortes, esto es, una institución monárquica en constante dialéctica y negociación con diversas comunidades políticas —actuando como repúblicas. Conviene desmontar algunos mitos sobre el absolutismo en la primera Modernidad hispánica y saber diferenciar ciertos lenguajes políticos oficiales propagandísticos de las realidades políticas que acaecieron en realidad. Todas estas cuestiones, desarrolladas por autores como Ernst Kantorowicz, José Antonio Maravall, José Manuel Nieto Soria, Henry Kamen, Anthony Pagden, Pablo L. Alonso Baelo, José Luis Villacañas, o Perry Anderson, entro otros, las veremos con detalle en el próximo capítulo en un apartado ex profeso ${ }^{92}$.

iii) Ya acerca de la tercera cuestión que imposibilita el uso de esta noción de humanismo cívico — tal y como ha sido descrita por Hans Baron, P.G.A. Pocock y sus escuelas - para el caso del republicanismo hispánico, recordemos que es el hecho de tener éste una visión escatológica de la filosofía de la historia. Como venimos reiterando, sostenemos que el pensamiento republicano converso castellano del cuatrocientos que nos ocupa en este trabajo — así como

\footnotetext{
${ }^{92}$ Kantorowicz (1985), Maravall (1967b), Nieto (1988) (1993) (1995) (2005), Kamen (2014), Pagden (1991), Alonso Baelo (2007), Villacañas (2005) (2014) (2017), Anderson (1999).
} 
el republicanismo hispánico e hispanoamericano en general - tiene una concepción de la historia escatológica. Y sostenemos también que en su particular implementación de valores republicanos, éstos se hibridan con el cristianismo. En el ámbito hispánico se dio un modelo político "moderno" sin necesidad de separar el reino de los hombres del reino de Dios. No estimamos que el secularismo ni implique, ni sea garante per se de modernidad política ni de republicanismo, no es su condición suficiente y necesaria. Sobre todo, no pensamos que el caso hispánico, donde el eschaton pervive, haya ser declarado por ello incompatible con los valores republicano. En esto coinciden con nosotros autores como Enver Torregroza, Miguel Pérez Herranz, J. M. Nieto Soria, Elías Palti, Francisco Quijano, Fernando Vallespín, Gabriel Entin o David Brading. Este último, aunque para el ámbito hispanoamericano y ya más para la época de las independencias, habla de una tradición de «republicanismo de tintes católicos» ${ }^{93}$. Por su parte, el estudioso Enver Torregroza explica así lo que sucede en la Castilla del XV, algo que confirmará nuestro texto de estudio, el Defensorium unitatis christianae ${ }^{94}$ :

La fe cristiana no significa necesariamente una negación del mundo ni una postura esencialmente antipolítica, enemiga de toda res publica. En otros ámbitos intelectuales europeos, los debates teológico-políticos generados con la introducción de la Política de Aristóteles en la vida universitaria del siglo XIII condujeron paulatinamente a la separación cada vez más radical de la espada temporal espiritual (...) Pero en el mundo hispánico, la política se hizo, más que cristiana, católica, puesto que la Ciudad Fiel que albergaba a todo los hombres bautizados requería de la Ciudad, de la filosofía política clásica, como interpretación correcta de la Ley divina.

Gabriel Entin sostiene que la república en el mundo hispánico ha estado conformada con un horizonte religioso en el que se articulan derechos republicanos con virtudes católicas. Apunta este estudioso: «En la visión confesional de la política de la monarquía española, la religión era un elemento constitutivo de la república, basada en el ideal de la res publica christiana y

\footnotetext{
${ }^{93}$ Torregroza (2008) (2010), Pérez Herranz (2016), Nieto Soria (2005), Palti (2002) (2012), Quijano (2017), Vallespín (2002), Entin (2018), Brading (1991): 96.

${ }^{94}$ Torregroza (2010): 184.
} 
una communitas perfecta» ${ }^{95}$. De todos modos, esta imbricación entre el papel del hombre en el devenir histórico-político y lo escatológico era algo ya heredado y mantenido desde la época romana — pese a la idea que sostiene Pocock de que opera la noción agustiniana de necesaria separación entre la historia profana de la ciudad terrenal y la Civitas Dei, y a pesar de su idea de desvinculación de la salvación y la historia- ${ }^{96}$. Ejemplos como De Consolatione Philsophiae de Boecio, obra de enorme influencia en la escolástica medieval posterior, son magníficos exponentes de cómo estos pensadores cristianos estaban enormemente preocupados por cuestiones cívicas.

A pesar de que Pocock vincule el humanismo cívico necesariamente con una filosofía de la historia secular y asevere que en éste se suple la gracia por la política: «El humanista cívico podía llegar a esos extremos y ser conducido por su decisión de abandonar tanto las formas tradicionales de la política como las eternas, para intentar realizar los valores universales de la polis en la forma particular, finita e histórica que era la república», reconoce que elementos como el profetismo articulan un enfoque escatológico de la filosofía de la historia con la dimensión secular de la idea de fortuna (ligada en su trabajo a la idea de virtud cívica en sentido maquiavélico) ${ }^{97}$. Así lo expone ${ }^{98}$ :

(...) Dios se había manifestado a sociedades humanas - Israel, la Iglesiay había contribuido a institucionalizarlas y a dotarlas de una historia. Esto era lo que las hacía importantes en todas las tentativas de revivir la escatología política. La profecía representaba la intervención pública de la providencia: unía la fortuna convertida en providencia por la fe y la fortuna dimensión histórica de las sociedades seculares (...) En este caso, la historia profética operaba como un instrumento para politizar la gracia y resacralizar la política. La construcción de San Agustín podía ser abandonada en el instante en que fuera posible identificar los momentos de la historia de las sociedades civiles con los momentos de escenario escatológico que iban a derivarse los distintos libros proféticos.

\footnotetext{
${ }^{95}$ Entin (2018): 111. La traducción es nuestra, el texto original es: "In the confessional vision of politics of the Spanish monarchy, religion was a constitutive element of the republic, base don the ideal of the res publica christiana and a communitas perfecta".

${ }^{96}$ Pocock (2002): 118-120.

${ }^{97}$ Pocock (2002): 165.

${ }^{98}$ Pocock (2002): 127-128.
} 
Como veremos con detalle al analizar del Defensorium Unitatis Christianae (1449) de Alonso de Cartagena, epítome de este republicanismo de índole conversa de la Castilla del siglo XV y obra que es objeto de nuestro estudio de caso, la idea de república cristiana y la teleología de la salvación estaban articuladas con el vivere civile. De hecho, el impulso teleológico escatológico de la salvación había de complementarse con una vida activa civil, cuya virtud cívica contribuía también a la salvación. La moral cristiana se alineaba con el vivere civile, con la acción política. No podemos obviar que el contexto normativo del XV castellano incorporaba lo trascendental. La res publica también se orientaba en torno a la idea de la unidad de la fe. Consolidar la comunidad política, la república civil, era consolidar también la comunidad cristiana, la república cristiana, y viceversa. Nociones como la gracia, el universalismo paulino o el bautismo, se entrelazaban con la noción de república. Además del bien común, la república también tenía el propósito de la salvación, pero esto no implicaba una deflación de su republicanismo, bien es cierto que el impulso teleológico primordial era escatológico, pero se complementaba con un impulso teleológico cívico, y ambos se retroalimentaban ${ }^{99}$.

Los elementos teológicos se alinean con elementos políticos propios de la recuperación del republicanismo clásico, queriendo contribuir a la incorporación de estos últimos en la realidad política y jurídica. Y esto sucede en dos sentidos simultáneamente, una bidireccionalidad propia de toda simbiosis. La vida activa se orienta también en la línea de una teleología de la salvación, es decir, está motivada por el objetivo de la salvación, y ya no sólo la vida contemplativa es lo propio de la vida cristiana y lo que permite la salvación, sino que también lo es el ideal de vida activa, de vida cívica. Y el que el objetivo último de las acciones políticas pueda ser la salvación, o la

\footnotetext{
${ }^{99}$ Por ejemplo la teología de la liberación de mediados del siglo XX lleva esto al máximo con su noción teológica de de "paraíso en la tierra".
} 
implantación de unos ideales de justicia y amor cristianos, no implica que éstas sufran una deflación de su potencia política, es sólo que lo teológico y lo político se articulan (algo que podemos ver en este republicanismo converso en el siglo XV castellano).

Por otro lado, se redimensionan e instrumentalizan elementos teológicos como vehículos para implementar objetivos políticos. Nos explicamos, el bautismo (fenomenología de la universalidad de la gracia), por ejemplo, es comprendido como un garante civil de la posibilidad de acceso a la participación política esto es, de inclusión - y como una herramienta para restituir o ganar el honor y así no ser víctima de exclusiones jurídicas y poder entrar en la vida civil. Usando un lenguaje contemporáneo a nuestros días, podríamos decir que el bautismo sería un "garante de derechos". En autores como Alonso de Cartagena un elemento como el bautismo se entiende como un catalizador de ciudadanía (lo veremos con detalle en el capítulo cuarto de esta tesis).

Es importante también para entender cómo se entrelazan republicanismo y religión, la noción de comunidad cristiana, la communitas cristiana. Sigo a José Luis Villacañas al explicar cómo el "nosotros" de la comunidad religiosa - su unión, su filia, el ser un solo cuerpo místico- fortalecen la idea republicana de bien común: en el cuidado común del nosotros se genera la virtud política (y también se genera, además, redistribución del poder) ${ }^{100}$. Conviene apuntar aquí que hemos de diferenciar, tomo esto de Villacañas que a su vez lo toma de Foucault - entre gobierno pastoral y gobierno republicano, el primero sería negativo porque es imperial. Por ejemplo los primeros cristianos ganaron al imperio, pues contaban con un nosotros tan sólido que implicaba un gobierno republicano, su comunidad cristiana implicaba una forma de comunidad política. La comunidad nos dará el cuidado del nosotros que posibilita y antecede al cuidado del sí, en una teoría política de la fraternidad. Continúa explicado Villacañas que, de acuerdo con Pablo, una

${ }^{100}$ Villacañas (2016b). 
criatura no puede llegar a la virtud, al cuidado de sí, sin la aceptación de la gracia (que implica de inmediato la entrada en la comunidad política), y que es por ello que Maquiavelo se equivoca cuando dice que catolicismo no puede recuperar nada para la política. La potencia política que activa lo común viene producida por una reinterpretación del cristianismo y no por una recuperación de lo griego. Jorge Alemán, por su parte, estima que en el núcleo emancipador del cristianismo hay algo — un resto, un fondo - no "matable", en el sentido de irreductible y perdurable, y éste es la unión, la comunidad que inaugura el sacrificio de Cristo y reproduce la gracia y la unión en el cuerpo místico de la Iglesia $^{101}$.

Además, ahondando en esta cuestión de la filosofía de la historia no secular para el caso del republicanismo castellano, hemos de recordar que éste estuvo permeado con lo semítico, cuya cosmovisión obviamente no es secular. El profetismo heredado de la cosmovisión judía a los pensadores conversos enriqueció la construcción particular del concepto de monarquía hispánica, así como una noción de pueblo, también fundacionalmente relacionado con lo religioso y con la idea de comunidad política de salvación. Abordaremos todo esto al analizar el Defensorium unitatis christianae de Alonso de Cartagena en el Capítulo 4.

Al hablar de esta retroalimentación entre lo religioso y lo cívico en el caso que nos ocupa - el del pensamiento político converso castellano de los siglos XV y XVI, sobre todo del siglo XV, por ser el ámbito temporal del autor en el que nos centramos, Alonso de Cartagena (1384-1456) - pudiera tal vez generarse una confusión y pensarse que podríamos referirnos a los denominados humanistas cristianos o los neoplatónicos italianos, como Lorenzo Valla, Marsilio Ficino, Pico della Mirandola, o Pietro Pomponazzi, entre otros, los cuales, como apunta Riccardo Fubini no tenían tampoco una concepción secular de la historia, y tomaron, asimismo, algunos elementos del pensamiento

${ }^{101}$ Alemán (2016). 
político florentino y se mostraron críticos con ciertas conductas corruptas de la Iglesia ${ }^{102}$. Sin embargo, estos neoplatónicos, no incorporan el ideal republicano de vita activa; además sus reflexiones se centran en cuestiones menos políticas y más relacionadas con la naturaleza humana y de índole espiritual, tratando tópicos como la dignitas y la miseria hominis, el debate en torno a la inmortalidad del alma y el materialismo, el intimismo religioso, el diálogo interreligioso o la renovación espiritual, entre otros. Aunque el neoplatonismo también se desarrolló en Castilla, nuestro objeto de estudio aquí se centra en el pensamiento político converso que juristas y teólogos escolásticos desarrollaron y en el que intersectan republicanismo y cristianismo. De todos modos, esto no obsta, para que entre los diferentes autores pueda haber sugerentes similitudes y cruces.

Cabría preguntarse el porqué de esta vehemencia en autores como Baron o Pocock en ver excluyentes casi per se republicanismo y escatología, de pensar que el hecho de que el hombre asuma su compromiso de injerencia en lo histórico y tenga una vocación cívica es algo obligatoriamente ligado a asumirse como único agente de la Historia. Puede ser que la conciencia secular de algunos pensadores estimulase su compromiso cívico, pero eso no implica que el modelo de virtud y teleología cívica sean incompatibles con la idea de salvación o trascendencia. ¿Por qué seria más firme un desarrollo de la vida activa a través sólo de la virtud cívica, que un desarrollo de la vida activa que aúna virtud cívica y virtud cristiana? Como reconoce el propio Baron no siempre es así, por ejemplo, al hablar de Salutati, arguye que es su conciencia cristiana la que despertó su interés por la vita activa, asevera: «Lo que dio al canciller florentino el valor suficiente para discrepar de opiniones tan llenas de autoridad [como las de Petrarca] fue en primer lugar, su conciencia cristiana; recalcó más que Petrarca el golfo que debe separar el corazón de un cristiano de la indiferencia estoica hacia el mundo exterior ${ }^{103}$. Otro caso que menciona

\footnotetext{
${ }^{102}$ Fubini (2003).

${ }^{103}$ Baron (1993) :130.
} 
Baron es el de Ptolomeo (Bartolomeo) de Lucca (1236-1237), del cual dice aúna republicanismo y teología; hace notar incluso Baron que «(...) el espíritu público romano era semejante a la caritas, humilitas y paupertas cristianas » ${ }^{104}$

Teniendo en cuenta ejemplos como éstos, entonces, ¿por qué excluir sistemáticamente de la historia del republicanismo el caso hispánico sólo porque no tenga una cosmovisión secular de la filosofía de la historia?

Otro elemento que debemos mencionar a este respecto es la importancia que para la escolástica hispánica tuvo el Derecho Natural, acerca de ello es muy revelador el trabajo de autores como Anabel Brett, o Herbert Schambeck y Cristina Hermida del Llano ${ }^{105}$. En este campo del Derecho Natural fueron enormes los aportes desde el ámbito hispánico, sobre todo gracias a la conocida como Escuela de Salamanca o Segunda Escolástica, y también a su rama americana, por ejemplo en la concerniente a la implementación de nociones de Derecho subjetivo que luego serían fundamentales en el pensamiento occidental en relación a la libertad o la propiedad, así como en la cuestión

${ }^{104}$ Baron (1993):174-175.

${ }^{105}$ Brett (1997) (2011). Concretamente sobre el caso hispánico de la Segunda Escolástica, véase el capítulo "Liberty and nature: subjective right and Thomism in sixteenth-century Spain, en Breyy (1997): 123-164. Schambeck y Hermida del Llano (2012). También, acerca del orden jurídico medieval, puede verse Grossi (1996). Siguiendo a Annabel Brett (1993) y Francisco Quijano (2017) exponemos aquí unas muy generales pinceladas al respecto de la noción de Derecho Natural: De acuerdo la interpretación tomista de Aristóteles, podríamos decir muy grosso modo que el Derecho Natural lo conformaban una serie de preceptos universales y conclusiones de ellos derivados, que todo hombre podía deducir a través de la razón natural sin necesidad de ningún otro precepto exterior, a través de los que estructurar la vida moral. Por tanto, el mundo social se correspondía a un orden de las cosas derivado de la naturaleza. El principio fundamental era garantizar la conservación de la vida y buscar el bien vivir, del individuo y de la comunidad. En la organización de la vida social el Derecho Natural se erigía como referente objetivo que ofrecía un orden para estructurar la vida social y moral de la república. Según el Derecho Natural había preceptos primarios y secundarios, los primeros estaban orientados sobre todo a la autoconservación y convivencia y eran iguales para todos los hombres, independientemente del contexto, los segundos (que sí podían variar según las circunstancias) eran conclusiones derivadas de los primarios y servían para lograr e implementar los primeros. Como ya vimos, el poder político existía por naturaleza y era transferido después al gobernante por la comunidad, por tanto, el poder político estaba fundamentado en el Derecho Natural, pues, siguiendo la teoría aristotélica, el hombre como animal social que es, requiere la comunidad para sobrevivir, y ésta, a su vez, precisa de quien la lidere y gobierne, pero para que este gobierno fuera legítimo debía no contradecir del Derecho Natural. Todo hombre y todo gobernante estaba sujeto a Derecho Natural. También la noción de libertad estaba ligada al Derecho Natural al ser entendida como una facultad del hombre, fundada en su razón y en su voluntad de tomar decisiones (aunque éstas no debían ir en contra de los preceptos del propio Derecho Natural). Conviene recordar que la interpretación escolástica hispánica se distancia de Aristóteles en cuanto a que no apoya la teoría de la servidumbre natural, pues ésta iría contra el Derecho Natural. 
acerca de cómo los pueblos infieles, pese a serlo, no perdían las libertades y "derechos" propios del Derecho Natural.

Finalizando este parágrafo iii) — que ha consistido en hacer ver que para el caso hispánico hay una visión escatológica de la filosofía de la historia, pero que ésta es compatible con la idea de republicanismo (aunque no con la denominación humanismo cívico y, precisamente, por ello no pueden identificarse humanismo cívico y republicanismo) - y volviendo ya al tronco general de este apartado, quepa apuntar que podría parecer controversial sostener que sí se dieron elementos republicanos en el ámbito hispánico dada la postura habitual en la historia de la filosofía política. Postura que se nos antoja muy extraña teniendo en cuenta que, por otro lado, son numerosos los estudios sobre los autores de la conocida como Segunda Escolástica - o Escuela de Salamanca - en los que se ensalzan por ejemplo su dimensión contractualista frente a los enfoques teocráticos absolutistas en lo concerniente al origen y la legitimidad de la autoridad, o en los que se ensalza su crítica al uso indiscriminado de una autoridad tiránica; en los que se resalta, en definitiva, su vocación jurídica y su constitucionalismo, rasgos éstos muy cercanos al republicanismo. No es nuestra intención en absoluto el generar controversia, pero sí estimamos de justicia el cubrir lo que consideremos un vacío y una limitación en los estudios hegemónicos sobre republicanismo, al negar éstos la existencia de republicanismo en el espectro de la modernidad hispánica, tanto ibérica como americana, y/o al sostener que el humanismo cívico es la única forma de republicanismo propia del siglo XV.

Apunta el importante historiador británico John H. Elliott que cuando se habla de atlantismo y de republicanismo atlántico se ha cometido el error de tener en cuenta sólo las orillas septentrionales del mismo, pero se ha olvidado con demasiada frecuencia su manifestación austral ${ }^{106}$. En la misma línea está Bernard Baylin ${ }^{107}$. Cuando se apela a lo atlántico en la historia del republicanismo y de la filosofía política, también habría que contar, por ejemplo, a lugares como Sevilla y Veracruz, algo que autores tan relevantes como Pocock han

\footnotetext{
${ }^{106}$ Elliott (2006).

${ }^{107}$ Baylin (2005).
} 
omitido $^{108}$. El estudioso Gabriel Entin, en relación a una serie de textos que ha aglutinado como material de trabajo en un muy interesante y necesario dossier sobre republicanismo hispánico, denuncia en nuestra misma dirección ${ }^{109}$ :

El hilo común entre todos ellos está dado por la reflexión sobre el republicanismo en un espacio común, el hispánico, que hasta hace pocos años permanecía excluido o al margen de la historiografía sobre la tradición, la cultura y los lenguajes republicanos en el mundo atlántico (...) Una de las razones de la exclusión del mundo hispánico de la tradición republicana atlántica residió en una visión restringida del "Atlántico". Esta visión privilegió ciertos espacios y experiencias respecto a otros (...) Una tercera razón que explica la marginación historiográfica del espacio hispánico en la tradición republicana atlántica se relaciona con la misma categoría de "Revolución atlántica" (...) La renovación de la Historia atlántica desde el mundo anglosajón —en la que Bailyn y John Elliot tuvieron un rol fundamental—, y desde el mundo hispánico —en donde Reforma y disolución de los imperios ibéricos 1750-1850 de Tulio Halperín Donghi (1985) representó una obra pionera-_ contribuyeron a repensar la categoría de "Atlántico" y considerar al mundo hispánico como otra experiencia del republicanismo atlántico.

Nuestra intención no es polemizar, sino entender mejor cómo fue la implementación política de la Modernidad en el ámbito hispánico así como enriquecer en la medida de nuestra humilde contribución los estudios sobre republicanismo. Afortunadamente, cada día hay más estudiosos que están intentando revertir esta tendencia de invisibilización del republicanismo hispánico, tanto ibérico como iberoamericano ${ }^{110}$. En los últimos años están emergiendo por fin diversos trabajos en torno al republicanismo en el ámbito hispánico, concretamente respecto al caso castellano en los siglos XV y XVI, y se está revitalizando el interés en una lectura republicana otros autores, más allá que de los más comúnmente estudiados miembros de la célebre Escuela de Salamanca o Segunda Escolástica. Coinciden muchos expertos en la existencia de ideas de índole republicana y constitucionalista en la Castilla del XV y principios del XVI y en la importancia y repercusión intelectual de éstas, aunque difieran quizá en cuánto se logró implementar este ideario como práctica política, sobre todo, tras el fracaso de la

\footnotetext{
${ }^{108}$ Prácticamente sólo para el caso del Caribe, sobre todo por la revolución de Haití, se ha hablado algo de republicanismo en el Atlántico no anglosajón.

${ }^{109}$ Entin (2016).

110 Nos referimos, entre otros, a teóricos como John Eliott, José Luis Villacañas, Antonio Rivera, José Antonio Maravall, Xavier Gil Pujol, Anthony Pagden, Víctor Egío, Enrique Marcano, Joan Pao Rubiés, Domingo Centenero, Cirilio Flórez Miguel, Pablo L. Alonso Baelo, Javier Peña, Ramón Ruiz, Pablo Fernández Albaladejo, María Martín, Francisco José Aranda, José Damiao Rodrigues, Javier López Alós, Rafael Herrera, Javier Fernández Sebastián, Enrique Marcano, Elías Palti, Gabriel Entin, Francisco Quijano, Tulio Halperin, David Brading, Ambrosio Velasco, José Antonio Aguilar o Rafael Rojas.
} 
revolución comunera; veremos todo ello con detenimiento en el próximo capítulo. Sostenemos, además, que este republicanismo castellano de los siglos XV y XVI, determinó e influyó en el republicanismo en el Nuevo Mundo. Como expone por ejemplo Ambrosio Velasco: «La exclusión del pensamiento republicano del pensamiento iberoamericano, dentro del actual resurgimiento de la tradición republicana, resulta totalmente injustificada en cuanto que desde la Edad Media hubo importantes ideas, instituciones y prácticas republicanas en diferentes reinos de España, especialmente Castilla y Aragón y a partir del siglo XVI se desarrolló una vigorosa tradición republicana en España y en Iberoamérica (...)» ${ }^{111}$.

Tal y como mencionábamos al final del apartado previo, al plantear nuestras discrepancias con el enfoque de Pocock, hay varios elementos de distancia entre la forma en que entendemos se interioriza y materializa el republicanismo en Castilla, y las características inherentes a la categoría de humanismo cívico tal y como éstas se han consolidado en la academia. Analizar las especificidades castellanas y su origen es el cometido del siguiente capítulo. Sin embargo, y esto es muy importante señalarlo, lo anterior no resta para que haya otros puntos coincidentes entre la adaptación de la tradición política republicana en Castilla y su adaptación en el caso florentino, descrito como paradigmático, así, por ejemplo: el ideal de vita activa, la ideal de bien común, la vocación de participación en el vivere civile, la concepción de la libertad como no dominación, la idea de que el origen de la potestas es transferida en origen al pueblo, el parlamentarismo y el constitucionalismo como formas de limitar el ejercicio de la autoridad, el ideal de servicio público, el anhelo de conformación de comunidad política, la noción de virtud cívica, etc.

Una vez lo hagamos, el lector podrá comprender a cabalidad a qué nos referimos cuando hablamos de pensamiento político converso, denominación que proponemos para referir a este tipo específico de pensamiento republicano castellano del siglo XV. De hecho, como ya hemos explicado, el habitual relato sobre el republicanismo ni siquiera contempla el caso castellano. Y, por ende, no da cabida a rasgos definitorios de éste, tales como: el factor judeoconverso; la pervivencia de la escolástica; la impronta de la filosofía árabo-semítica peninsular medieval; la huella del profetismo hebreo y su noción de pueblo; la pervivencia eschaton en la concepción de

\footnotetext{
${ }^{111}$ Velasco (2006b): 26.
} 
la filosofía de la historia; la tradición jurídica hispánica Alfonsina; el aristotelismo cristiano; la articulación entre teleología de la salvación y vita activa, así como la articulación de elementos teológicos con elementos del republicanismo clásico; la importancia del conciliarismo castellano; o la concepción de la monarquía hispánica existente: gótica, no teocrática (aunque cristiana y vicaria de Cristo), organicista, y ya con elementos parlamentaristas. Por todo ello, usar una categoría como humanismo cívico, tal y como está planteada, para el caso castellano implicaría poca exactitud, además de cierta subordinación cultural y académica a la historia hegemónica de la filosofía política y del republicanismo. Esto no implica en absoluto, sin embargo, a nuestro entender, que el pensamiento político converso castellano no participase de muchas de las características de lo que los estudiosos han descrito como humanismo cívico o humanismo político (denominación ésta, acuñada por Guido Cappelli, que tampoco es pertinente para nuestro caso, pues remite a un universo humanista y laico) ${ }^{112}$. Por todo ello, así como para lograr mayor claridad y especificidad, hemos propuesto una nueva denominación aplicable al pensamiento político de ciertos intelectuales en la Castilla del XV, denominación que ya implica una determinada implementación del republicanismo. Dicha denominación, que ya hemos venido anticipando es la siguiente: pensamiento político converso. O, yendo más allá en nuestra propuesta, y siendo más precisos: pensamiento republicano converso. Para explicar el porqué la proponemos ha sido este capítulo, en el siguiente veremos el contexto intelectual que es su condición de posibilidad.

Es en lo explicado en las páginas previas en lo que se ha basado nuestra problematización del uso de la categoría humanismo cívico, que no opera para nuestro caso de estudio, el cual estimamos es la principal manifestación política del pensamiento político castellano del siglo $\mathrm{XV}$. Específicamente no opera la categoría humanismo cívico para el caso concreto del pensamiento político de ciertos intelectuales conversos - fundamentalmente Alonso de Cartagena - que son el objeto de este trabajo. Y es por todo ello, como hemos dicho arriba, y con el fin de que quede incluido nuestro objeto de estudio y sus características diferenciadoras dentro de la historia del pensamiento político y de la historia del republicanismo, que hemos propuesto tal denominación.

${ }^{112}$ Capelli (2011). 
Otros estudiosos cuyo trabajo hemos descubierto posteriormente a proponer esta denominación (y con los cuales compartimos numerosas ideas) usan denominaciones semejantes para referirse al grupo de conversos líderes de la intelectualidad castellana del momento, aunque no necesariamente remiten a su pensamiento político. Así, Fernando Miguel Pérez Herranz habla de humanismo castellano converso y Enver Torregroza de racionalismo converso ${ }^{113}$. Lo veremos con más detalle en el apartado 2.1 del siguiente capítulo. No obstante, nosotros hemos querido mantener nuestra denominación por estimarla más apropiada para hablar de este pensamiento político específico. Como ya explicamos en el punto 1.2 el término humanismo, que emplea Pérez Herranz, nos resulta problemático. Y hablar de racionalismo converso, como hace Torregroza, no nos resulta clarificador y nos traslada a un ámbito más epistémico que político. Como en este trabajo estamos abordando el pensamiento político de estos intelectuales castellanos del XV, nos parecía importante que estuviese presente el término «político». De todos modos, insistimos, también la denominación acuñada por nosotros en esta tesis «pensamiento republicano converso» resultaría idónea.

E incluimos la palabra converso, con dos intenciones 1) Acotar temporalmente (siglos $\mathrm{XV}$-XVI) y referirnos al origen, matriz filosófica, y circunstancia personal de los intelectuales, juristas y teólogos promotores de dicho pensamiento político (cuestión ésta del estar sometido a una vivencia de exclusión de la posibilidad de participación civil por ser judío converso que, sostenemos, determinará su particular introyección del republicanismo, aunque no sólo, pues influirán también otros aspectos como su vocación de creación de comunidad política que sea a la vez comunidad de salvación, o su profetismo). Y 2) Recalcar la dimensión religiosa -cristiana, pero también con elementos semíticos - de este pensamiento político. Dimensión religiosa que no es un aditamento sino que es esencial en la conformación de este pensamiento político, pues éste está marcado por el hecho de que elementos republicanos y religiosos se complementan. Precisamente, la circunstancia de lo converso (sobre todo la vivencia de exclusión y la forma de entender la religiosidad) determinará cómo es el pensamiento político de estos intelectuales castellanos y cómo su adaptación de los valores republicanos. Una adaptación en la que lo religioso y lo republicano se retroalimenta. Cuestiones como la universalidad de la gracia y la revelación, el bautismo, la idea de cuerpo místico o de comunidad de salvación se politizan

113 Pérez Hérranz (2016), Torregroza (2008) (2010). 
entendiéndose como garantes de acceso a la ciudadanía, de restitución del honor, de igualdad y de unidad; en definitiva, como vehículos de inclusión, de posibilidad de participación en el vivere civile y de consolidación de comunidad política. Como explicaremos más adelante, una teleología de la salvación y una teleología de la virtud cívica republicana se hibridan en este pensamiento político converso.

Creemos que no es aventurado aseverar que en el caso del pensamiento hispánico precisamente este maridaje entre teología y política fue catalizador de realidades que hoy entendemos como derechos. Este hilo conductor entre valores republicanos y religión que se dio en autores como el que nos ocupa, Alonso de Cartagena, y es muy sugerente intelectualmente reivindicar esta bisagra; además de necesario si pretende hacerse un trabajo de arqueología crítica de la Modernidad hispánica. Ésta se ha analizado normalmente bajo limitadoras comprensiones parciales de fenómenos complejos, los cuales, además, se nos han presentado en términos antagonistas, esto es: republicanismo vs. monarquía (encarada de antemano como su perversión tiránica), o humanismo cívico vs. teología política (sin pensar en los matices y variantes dentro de este último sintagma). Tal vez deberíamos asomarnos a todas estas aparentes disyuntivas con un enfoque más dialéctico: en el pensamiento político castellano conviven en tensión y mutuo enriquecimiento la teología política, los elementos republicanos, el concepto atávico de monarquía hispánica, y el monarquismo organicista. Desde luego, al menos para el caso castellano, es necesario este abordaje más dialéctico. Tal vez, el quid de la cuestión sea entender la noción de republicanismo de un modo más flexible, menos rígido, es decir, como algo más poliédrico, y así no encontrar incompatibilidades —que ven nuestros ojos contemporáneos - donde no las había. Sólo así nos podrá resultar inteligible y coherente que en Castilla haya una revolución comunera de cariz republicano en 1521 pero que ésta no cuestione la institución monárquica como tal (sí a un rey que se percibe como no virtuoso y al que es lícito deponer a favor de otro, pero no la institución), o que el acceso a la esfera de la comunidad política sea vía la instrumentalización cívica de elementos religiosos, superponiéndose así la idea de communitas cristiana y la de comunidad republicana.

Analizar el contexto filosófico, teológico, político, social, cultural y jurídico que hicieron posible este pensamiento político converso, o pensamiento republicano converso, es el objetivo 
de nuestro próximo capítulo. Dentro de las figuras más destacadas que cabrían bajo este rubro de pensamiento político converso hemos seleccionado el elenco que añadimos a continuación (si bien en él no todos los autores eran conversos, sí la mayoría, y los que no lo eran aun así eran afines a este círculo — que además defendían- y compartían su contexto intelectual y su orientación en múltiples aspectos). Salvo el caso de Alonso de Cartagena en quien nos detendremos, lamentablemente y por una cuestión metodológica, tan sólo podemos aquí mencionar a estos pensadores. De algunos hemos haremos a lo largo de este trabajo breves apuntes, pero otros tan sólo los enumeraremos aquí para que el lector tenga la información de qué otros nombres además de Alonso de Cartagena — uno de sus protagonistas - forman parte de este pensamiento politico converso que nos ocupa y que tratamos de visibilizar y analizar. Además, así sugerimos posibles futuros estudios sobre estos otros pensadores. Pues bien, centrándonos en los autores que trataron temas filosóficos, políticos, teológicos y jurídicos, podemos señalar, entre otros, los siguientes nombres:

- Clan de los Santa María, también conocidos como "de Cartagena" (de origen hebreo y antes de la conversión al cristianismo llamados familia Ha-Levi). A esta familia pertenece al Alonso de Cartagena (1384-1456). Dicho clan lo inauguró Pablo de Santa María (1353-1435, padre de Alonso) y también destacaron en él por sus escritos y actividad política y religiosa, Alvar García de Santa María (1370-1460, hermano de Pablo), Gonzalo de Santa María (1379-1448, hijo de Pablo y hermano de Alonso) o Teresa de Cartagena (c.1425-?, sobrina de Alonso).

- Fernán Pérez de Guzmán (1376-1458)

- Lope Barrientos (1382-1469)

- Enrique de Villena (1384-1434)

- Juan de Torquemada (1388-1468, nos referimos a Juan, no a su tío Tomás el inquisidor General)

- Juan de Segovia (1395-1458) 
- Íñigo López de Mendoza, Marqués de Santillana (1398-1458)

- Alfonso Fernández de Madrigal ‘El Tostado’(1400-1455)

- Diego Arias Dávila (1400-1466)

- Rodrigo Sánchez de Arévalo (1404-1470)

- Alfonso de la Torre (1410-1460)

- Pero Díaz de Toledo (1410-1466)

- Diego Valera (1412-1488)

- Gómez Manrique (1412-1490)

- Fernán Díaz de Toledo (?- ?)

- Alonso de Palencia (1423-1492)

- Pedro Díaz de Toledo y Ovalle (1425-1499)

- Diego Rodríguez Almela (1426-1492)

- Pedro de Osma (1427-1480)

- Fernando de Roa (?- ?)

- Hernando de Talavera (1428-1507) 
- Juan de Lucena (1430-1506)

- Fray Alonso de Oropesa (?- ?)

- Hernando del Pulgar (c.1436-1493)

- Juan Arias Dávila (1436-1497)

- Antonio de Nebrija (1441-1522)

- Francisco Ramírez (1445-1501)

- Fray Ambrosio Montesino (1444-1514)

- Alfonso Ortiz (1455-1503)

- Diego Ramírez de Villaescusa (1459-1537)

- Fray Antonio de Montesinos (1475-1540)

- Pascual de Aranda (?- ?)

- Alonso de Castrillo (?- ?)

- Pedro López de Ayala (1485-1524)

Pasaremos, en seguida al segundo capítulo, sin embargo, aún no están realizadas todas las acotaciones y aclaraciones terminológicas en que consistía el presente. Falta un muy breve apartado, el siguiente, en el que simplemente queremos exponer cómo usaremos el sintagma teología política - también controvertido-. 


\subsection{Breve apunte sobre cómo abordaremos la noción de teología política.}

Este breve punto tiene sólo un fin aclaratorio, el hacer notar que a lo largo de este trabajo usaremos el sintagma «teología política» de la manera más aséptica posible, esto es, en sentido literal, tratando de quitarle en la medida de lo posible la carga que le implica el ser ya todo un concepto, con las implicaturas que esto tiene desde la historia conceptual. Simplemente queremos que sea entendido como articulación entre lo religioso y lo político, y lo usamos queriendo ser coherentes en todo momento con el contexto del $\mathrm{XV}$, que en todas las dimensiones incorporaba lo trascendental — no era aún antropocéntrico-, pues querer zafarse de lo religioso en pos de demostrar una modernidad directamente proporcional a una secularidad —entendida además, opinamos, desde los debates al respecto del presente- nos resulta un grave anacronismo y un artificio académico. No pensamos que modernidad implique necesariamente secularización (puede implicarla, al igual que otras variables, pero no es su condición suficiente y necesaria), al igual que no pensamos que republicanismo implique necesariamente filosofía de la historia secular; y no aseveramos esto de modo controversial en absoluto, al contrario, simplemente histórico.

Cabe esta aclaración de que nuestro uso de este sintagma será meramente denotativo, porque es un sintagma que resulta también muy problemático, dialéctico y que tiene toda su estela en el campo de la historia de la filosofía política y de la historia intelectual, pues suele percibirse con cierto prejuicio e identificarse de inmediato con manifestaciones como la tradición de la teología imperial o la anulación de la autonomía de la política. En realidad, lo usamos para referir nada más, y nada menos, a la impronta de lo teológico en lo político, y al carácter político del cristianismo, a su traductibilidad política. Pero nuestra intención $-\mathrm{y}$ lo necesario para hacer comprensible correctamente lo que queremos decir en esta investigación - es utilizar dicha expresión, teología política, ceñida al ámbito cristiano (más concretamente cristiano judeoconverso, por ser el que nos ocupa), y despojada de anacronismos. Emplearla, en la medida de lo posible, libre de cargas y connotaciones. Por tanto entenderla y aplicarla como la retroalimentación entre elementos teológicos cristianos y elementos políticos. Como un binomio simbiótico, siempre bajo una cosmovisión sagrada, de elementos teológicos (como la gracia, el bautismo, la comunidad cristiana, la redención, la revelación, el universalismo, la unión mística, 
o lo profético) y elementos políticos — propios del republicanismo del siglo XV- (como la virtud, la participación, el organicismo, el bien común, la creación de comunidad política o la libertad). Ya apuntamos esto en el apartado previo, punto 1.3.4, y lo retomaremos dándole un soporte textual en el capítulo 4 al analizar el Defensorium Unitatis Christianae, lo que es importante exponer aquí es el hecho que es así como abordaremos aquí sintagma teología política, y que de este enfoque están transidas las expresiones teología política conversa y pensamiento político converso que empleamos recurrentemente y que, precisamente, queremos visibilizar.

Por tanto, valga reiterar que el uso que le damos a la expresión teología política no está aquí vinculado a la idea de teología imperial, que es como se ha abordado en mucha ocasiones en el ámbito de la modernidad temprana, tampoco nuestro uso de este sintagma se centra en la cuestión de la legitimación religiosa del origen del poder, o en torno a la idea de potentia Dei (aunque éstos temas sí lo contemplaremos en el siguiente capítulo al hablar de la monarquía).

Asimismo, el modo casi literal en el que utilizamos el sintagma teología política no toma las formas en las que lo ha hecho en el sinfín de interesantes debates sobre la secularidad del siglo XX, al comenzar a hablar de los cuales suele repetirse la célebre cita de Carl Schmitt: «Todos los conceptos sobresalientes de la moderna teoría del Estado son conceptos teológicos secularizados» ${ }^{114}$. En dichos debates contemporáneos no se maneja tampoco una definición unívoca ni estable de dicho concepto de teología política, y éste sigue siendo escurridizo e inabarcable, como explica Aarón Attias en una reseña al libro de Roberto Esposito Dos. La máquina de la teología política y el lugar del pensamiento ${ }^{115}$ :

El autor parte de la siguiente premisa: si después de un siglo de discusiones no hemos logrado una definición estable del concepto de "teología política", es porque el léxico filosófico desde el cual lo pensamos está tan unido con este concepto que no podemos distanciarnos para criticarlo; si no podemos penetrar en el horizonte de la teología política es porque ya estamos en su interior, pues la teología política no es más que un concepto o un acontecimiento, es el eje en torno al cual ha pivotado gran parte de la civilización occidental.

\footnotetext{
${ }^{114}$ Schmitt (2009).

${ }^{115}$ Attias (2016): 598.
} 
Una materia ésta del debate en torno a la secularidad complejísima y en la que no es pertinente entrar ahora, y que implicaría, además, abordar numerosos autores ${ }^{116}$. No procede aquí ahondar en esta cuestión, pues nos desviaríamos ostensiblemente del núcleo de este trabajo, aunque ojalá las conclusiones de nuestro trabajo pudieran ser una contribución diacrónica, a modo de mediación, al debate más actual sobre post-secularismo — contribución en cuanto a los aprendizajes que este pensamiento político converso y un tratado como el Defensorium unitatis christianae nos otorgan acerca de cómo se han articulado en ocasiones lo republicano con lo teológico, o acerca de la conexión entre comunidad cristiana y comunidad política, o en cuanto a la conformación de una racionalidad política de la inclusión frente a la arbitrariedad política o jurídica de la exclusión, o en la medida de que es un alegato en pro de la convivencia. Esto es, el Defensorium puede ser una contribución ante, como dice Carlos Thiebaut, «la necesidad de recuperar en la reflexión política todo el arsenal denso y simbólico de las religiones —una maniobra de darle carne al entendimiento constitucional moderno y de posibilitar el acceso a las intuiciones políticas de la modernidad a sociedades que no han seguido el camino weberianoalgo que tampoco estaba lejano, entonces, de la discusión con Habermas y su idea de lo postsecular. Pero ¿no es ese post-secularismo algo similar, en un momento posterior de la espiral de la vida política, a lo que vemos en Cartagena?»» ${ }^{117}$.

Otro aspecto que deseamos resaltar es que esta manera de abordar el sintagma teología política es constitutivo diacrónicamente de eso que se ha llamado pensamiento hispánico, y de la histórica disidencia intelectual que éste ha supuesto muchas veces al quedar marginado de la praxis del poder (aunque no de la producción de discurso intelectual). A nuestro modo de ver, no es sólo que no podamos comprender el republicanismo hispánico de los siglos XV o XVI sin el cristianismo, es que éste está en intrínsecamente ligado con gran parte del pensamiento hispánico, pero no por eso su nivel de potencia política o filosófica es menor. La tarea aquí es dilucidar la forma en que el republicanismo se materializó en el ámbito hispánico, y eso pasa por tener en cuenta lo teológico. No debería obviarse la labor en muchas ocasiones de la teología como acicate para una mayor "democratización”, pensemos desde nuestros conversos con

\footnotetext{
${ }^{116}$ Nos referimos a pensadores como, entre otros, Max Weber, Carl Schmitt, Karl Löwith, Hans Blumenberg, Reinhart Koselleck, Hannah Arendt, Jürgen Habermas, Eric Voegelin, Girgio Agamben, Giani Vattimo, Massimo Rosati, Roberto Esposito, María Pía Lara, Jean-Claude Monod, Reyes Mate, y un larguísimo etcétera.

${ }^{117}$ Extraído del comentario del profesor Carlos Thiebaut a la lectura del borrador de esta tesis.
} 
valores republicanos, hasta la contribución —en la misma dirección — al Derecho Internacional y el llamado entonces Derecho de Gentes de la Segunda Escolástica española e hispanoamericana del siglo XVI, o en la dimensión política de las reducciones jesuíticas en los siglos XVII y XVIII, o más recientemente al papel de la Teología de la Liberación en movimientos pro justicia social y emancipación en la reciente historia de América Latina. Y pensamos que la conformación de ese pensamiento hispánico, le debe muchísimo al pensamiento converso castellano del XV que nos ocupa aquí.

\section{Conclusiones y aportes del Capítulo 1}

1) Problematización de la aplicabilidad de la categoría humanismo cívico para nuestro caso de investigación. Sostenemos que lo problemático no es la categoría en sí —aunque tiene limitaciones - sino sobre todo la extrapolación de esta etiqueta conceptual (que fue concebida para un contexto determinado pero se generalizó). Este hecho es doblemente problemático, pues dicha categoría ha devenido baremo único para la historia de la filosofía política de lo que implican la modernidad política y la recuperación del republicanismo clásico. Como hemos tratado de demostrar, el hipostasiar y generalizar esta categoría resulta inexacto, reduccionista, eurocéntrico, hegemónico, limitado, y tremendamente excluyente. Además se ha dado la incorrecta asimilación 'humanismo cívico = republicanismo en el siglo XV'.

2) Justificación de por qué esta categoría de humanismo cívico, tal y como está descrita no es apropiada y no opera para el caso que nos ocupa, esto es, para una de las principales manifestaciones y lenguajes políticos de los siglos XV y XVI en Castilla (y no es tampoco adecuada para el caso de pensamiento y prácticas republicanas en el resto del llamado Mundo hispánico, es decir, para el ámbito hispanoamericano de la temprana Modernidad). Principalmente por las siguientes razones: porque en el ámbito castellano la filosofía de la historia es escatológica y no secular, por su apoyo a la institución monárquica — cuya noción es compatible con teorías contractualistas sobre el origen del poder, con modelos de gobierno mixto y está ligada al organicismo y al profetismo-, o por ser este republicanismo castellano del XV de corte escolástico. Sin embargo, nada de esto implica que no haya una recuperación de valores del republicanismo clásico en Castilla. 
3) Propuesta de denominación para nuestro objeto de estudio: pensamiento político converso (o bien pensamiento republicano converso). Propuesta acunada teniendo en cuenta lo anterior y considerando las variables que lo posibilitan y determinan, y cuyas características y agentes catalizadores desarrollaremos ya en el siguiente capítulo

4) Acotación y delimitación del uso que le daremos en este trabajo al sintagma teología política. 


\section{CAPÍTULO 2: El pensamiento político converso castellano del siglo xv y el contexto que lo}

determina.

\section{Introducción al Capítulo 2. Acerca del contexto intelectual, religioso y político-social.}

Cumpliendo con el objetivo general de visibilizar el pensamiento político castellano del siglo XV y hacer notar su relevancia y su impronta, y, concretamente, cumpliendo con el objetivo propio de este trabajo de visibilizar y describir una de sus principales manifestaciones, la que hemos denominado pensamiento político converso, y de mostrar sus características y particularidades, vamos a analizar en el presente capítulo su contexto intelectual. Es decir, vamos a abordar las condiciones de posibilidad de este pensamiento político converso (o pensamiento republicano converso): las causas que lo posibilitaron y determinaron, por qué surgió, qué problemáticas históricas trató de resolver, a qué tendencias intelectuales y espirituales se vinculó, en qué espacios de conflicto intervino, qué estrategias empleó, su postura frente al régimen político circundante, etc.

Nos hemos centrado en describir este contexto filosófico, religioso y socio-político que catalizó este pensamiento político converso con el fin justificar en base a él sus características y particularidades diferenciadoras. Hemos presentado este contexto intelectual en torno a una serie de ejes o variables que, según nuestro criterio, son los más significativos y los que más influyen dentro del contexto intelectual del siglo XV castellano en la conformación del pensamiento político converso. Esto es, son los ejes que pensamos más determinan al pensamiento político converso y que nos permiten comprender mejor en qué consiste éste y por qué tiene las características específicas y diferenciadoras que tiene. Sobre todo la característica que consideramos es la más relevante y distintiva y en la que vamos a centrarnos en el estudio de caso que ocupará la segunda parte de la tesis, el análisis del Defensorium unitatis chrtistianae (1449) de Alonso de Cartagena. Nos referimos a la característica de la articulación entre elementos teológicos y elementos republicanos, que es propia del pensamiento político converso y de la cual el texto de Cartagena es epítome. Esta articulación de elementos teológicos y elementos republicanos, sólo se podrá comprender si la entendemos como una resultado de la 
combinación de los ejes que planteamos a continuación como catalizadores del pensamiento político converso

Estos ejes en torno a los cuales hemos presentado dicho contexto, y los cuales entendemos que estaban íntimamente ligados y se influían recíprocamente, son los siguientes:

2.1) La cuestión conversa.

2.2) La función social del letrado.

2.3) La "Primera Escuela de Salamanca". Escolástica y pensamiento político.

2.4) Proto-reforma, paulinismo, organicismo teológico y conciliarismo en Castilla.

2.5) Acerca de la noción de monarquía.

2.6) El proyecto de un modelo de gobierno mixto. Las Cortes en Castilla durante el siglo XV: de Briviesca a Villalar.

El apartado que se centra en el eje «2.1) La cuestión conversa», remite a una circunstancia que afecta a la mayoría de pensadores que forman parte de este pensamiento político converso, una circunstancia que influirá en su demanda de una racionalidad política inclusiva y en la búsqueda de conformación de una comunidad cristiana cohesionada que sea, asimismo, comunidad política. Una circunstancia social -el trato discriminatorio a los judeoconversos - e intelectual — la matriz intelectual semítica— que será determinante.

Respecto al segundo eje, esto es «2.2) La función social del letrado», se refiere a la vocación de servicio público en pro del bien común que condujo a estos pensadores, los cuales acabaron teniendo un notable peso social al ocupar cargos como consejeros de Estado, profesores o eclesiásticos. Este ethos marcado por una vocación de servicio público se vinculaba con la idea de virtud. 
El tercer eje, «2.3) "La Primera Escuela de Salamanca". Escolástica y pensamiento político», muestra el papel aglutinante de esta institución como centro de formación de estos pensadores, y su papel como espacio de intercambio de ideas y creación de sinergias intelectuales. Asimismo, explica este punto cómo las corrientes filosóficas presentes en esta universidad son las que estarán presentes en el pensamiento político converso. Nos referimos a corrientes como la orientación escolástica, el iusnaturalismo, la relectura en clave cívica del aristotelismo, la recuperación de valores republicanos clásicos, el conciliarismo y su influencia en el constitucionalismo, o el pre-erasmismo.

En el cuarto eje, «2.4) Proto-reforma, paulinismo, organicismo teológico y conciliarismo en Castilla.» expondremos cómo era la religiosidad vivida por estos pensadores, y, sobre todo, su traductibilidad política, esto es, la adaptación política en el pensamiento y el proyecto político de estos pensadores de elementos como el universalismo paulino, la idea de cuerpo místico de Cristo aplicada a la idea de monarquía y de creación de comunidad política o la adaptación al constitucionalismo de principios conciliaristas.

Ya con el quinto eje «2.5) Acerca de la noción de monarquía.», entramos en una dimensión más concreta que aborda de la visión que estos pensadores tienen del sistema político que les es circundante, esto es, de la monarquía. Nos centraremos en este punto en explicar cómo dentro del enfoque de este pensamiento político converso es compatible, y de hecho, complementario, el apoyo a la monarquía con los ideales republicanos. Sobre todo en torno a la cuestión del origen de la autoridad y la necesidad de límites en el ejercicio de la autoridad real, explicaremos por qué vías. Asimismo, mostraremos que esta concepción de la monarquía, incluye elementos organicistas, providencialistas (no teocráticos, dejemos esto claro), proféticos y goticistas.

Finalmente, como último eje — de los que hemos considerado son los fundamentales para entender el contexto que es condición de posibilidad y que explica las particularidades de este pensamiento político converso - está el que explicaremos en el apartado «2.6) El proyecto de un modelo de gobierno mixto. Las Cortes en Castilla durante el siglo XV: de Briviesca a Villalar». 
En dicho punto abordaremos el proyecto político concreto que propone este pensamiento político converso. Es decir, cómo los elementos intelectuales que hemos visto que conforman los ejes anteriores y que estaban relacionados y se permeaban entre sí, tienen una materialización en un proyecto político. Este proyecto es el de gobierno mixto, el de una monarquía ejercida con el control complementario de la Cortes, en un sistema pactista o proto-parlamentarista. Expondremos cómo este proyecto se materializa en una agenda política - la Revolución Comunera- y cómo fracasa, quedando por ello bastante bloqueado el pensamiento político converso como realidad política, aunque se aplicará en algunos aspectos $\mathrm{y}$, sin duda, pervivirá fuertemente su impronta intelectual; es más, consideramos que su influencia será definitoria en la conformación del llamado pensamiento hispánico.

Asimismo, en este capítulo analizaremos dicho contexto intelectual con la originalidad de ir ya relacionándolo con el autor que nos ocupará en la segunda parte del trabajo, Alonso de Cartagena - cuya obra analizada, el Defensorium unitatis christianae entendemos como uno de los clímax este pensamiento político converso-.

Es conveniente antes de entrar en materia realizar un apunte metodológico que nos permita entender que las aristas que conformaban este contexto intelectual eran circunstancias de las que participaban en mayor o menor medida muchos de sus intelectuales y que estaban íntimamente ligadas y se influían mutuamente. Para entender el cómo, tomaremos lo que Weber llamó "afinidades electivas", y que aplicamos de la siguiente manera aquí: el que determinadas ideas o corrientes de pensamiento (que en principio no tendrían por qué asemejarse ni habrían de asimilarse), por razones externas de índole social exógenas a ellas mismas —en este caso por ser seguidas por conversos y parecer por ello heterodoxas y ser hostigadas - acaban asimilándose entre sí $^{118}$. Al decir esto pensamos en la tríada republicanismo/pre-erasmismo/problema converso (realidades que cristalizarán décadas después de la muerte de Alonso de Cartagena, acontecida en 1456, en hechos como el fracaso de la Revolución Comunera, la aparición de la Reforma protestante o la consolidación de los estatutos de limpieza de sangre para los cristianos nuevos,

\footnotetext{
${ }^{118}$ Max Weber en su célebre análisis sobre la ética protestante, le toma prestada esta expresión a Goethe, que tituló así una novela en 1809 (Die Wahlverwandschaften), y en la que uno de los personajes explica: «Llamamos afines a aquellas naturalezas que al encontrarse se aferran con rapidez las unas a las otras y se determinan mutuamente». Weber (2011).
} 
permitiendo azuzar esta asociación). Lo que pretendemos sostener es que quienes se sabían en esta órbita, tanto por el contenido de sus ideas, como por las circunstancias externas de persecución religiosa o política y de obligado apartamiento de la actividad civil, incorporaron a su pensamiento una vocación inclusiva e integradora detonada por su propia experiencia (una experiencia de daño). Vocación inclusiva que, además, para mayor coherencia, encajaba con sus presupuestos de apertura religiosa y espiritualidad renovadora o de deseo vida activa y participación en el vivere civile. Muchos de estos pensadores conversos eran religiosos y/u ocupaban cátedras y cargos administrativos en la corte de Juan II, Enrique IV o los Reyes Católicos, eran hombres de Estado con un claro sentido del bien común y el servicio público.

Aunque, como es obvio y como apuntamos en el capítulo previo, no todos los intelectuales que entrarían bajo este rubro de pensamiento político converso tuvieron un pensamiento homogéneo y no todos eran conversos (aunque sí la gran mayoría, y los que no, apoyaron fuertemente su causa y compartieron sus inquietudes y círculos intelectuales), sí podemos agruparlos teniendo en cuenta una serie de características comunes y considerando su cercana postura en relación a estos ejes en torno a los cuales hemos descrito este contexto intelectual, religioso y socio-político del XV castellano.

Como ya indicamos unas páginas más atrás, como figuras principales que cabrían bajo esta categoría de pensamiento político converso, destacamos primeramente a los miembros del clan de los Santa María, también conocidos como "de Cartagena" (de origen hebreo y antes de la conversión al cristianismo llamados familia Ha-Levi). A esta familia pertenece al Alonso de Cartagena (1384-1456). Dicho clan lo inauguró Pablo de Santa María (1353-1435, padre de Alonso) y también destacaron en él por sus escritos y actividad política y religiosa, Alvar García de Santa María (1370-1460, hermano de Pablo), Gonzalo de Santa María (1379-1448, hijo de Pablo y hermano de Alonso) o Teresa de Cartagena (c.1425-?, sobrina de Alonso). Asimismo, dentro de este elenco principal del pensamiento político converso incluimos, entre otros, a Fernán Pérez de Guzmán (1376-1458); Lope Barrientos (1382-1469); Enrique de Villena (13841434); Juan de Torquemada (1388-1468, nos referimos a Juan, no a su sobrino Tomás de Torquemada el inquisidor General); Juan de Segovia (1395-1458); Íñigo López de Mendoza, Marqués de Santillana (1398-1458); Alfonso Fernández de Madrigal 'El Tostado’(1400-1455); 
Diego Arias Dávila (1400-1466); Rodrigo Sánchez de Arévalo (1404-1470); Alfonso de la Torre (1410-1460); Pero Díaz de Toledo (1410-1466); Diego Valera (1412-1488); Gómez Manrique (1412-1490); Fernán Díaz de Toledo; Alonso de Palencia (1423-1492); Pedro Díaz de Toledo y Ovalle (1425-1499); Diego Rodríguez Almela (1426-1492); Pedro de Osma (1427-1480); Fernando de Roa; Hernando de Talavera (1428-1507); Juan de Lucena (1430-1506); Fray Alonso de Oropesa; Fernando del Pulgar (c.1436-1493); Juan Arias Dávila (1436-1497); Antonio de Nebrija (1441-1522); Francisco Ramírez (1445-1501); Fray Ambrosio Montesino (1444-1514); Alfonso Ortiz (1455-1503); Diego Ramírez de Villaescusa (1459-1537); Fray Antonio de Montesinos (1475-1540); Pascual de Aranda; Alonso de Castrillo; o Pedro López de Ayala (1485-1524); incluso hasta podríamos considerar incluir a Luis Vives (1492-1540) ${ }^{119}$.

Como segmentación temporal de este capítulo, y de este trabajo en sí, hemos delimitado el siglo XV y principios del siglo XVI, aunque, sin duda, la impronta política, teológica, intelectual y cultural de este pensamiento político converso castellano opera también durante los siglos XVI y XVII (su influencia va, por ejemplo, de la Revolución Comunera a la Segunda Escolástica, pasando por la Escolástica en Nueva España, la primera etapa de la Compañía de Jesús o la creación de ciertas obras cumbres de la literatura castellana). No es menester aquí detenernos en hacer un retrato histórico del convulso siglo XV castellano, pero al menos mencionaremos en nota al pie, a modo de recordatorio, algunos hitos políticos, culturales y religiosos determinantes para la Castilla del cuatrocientos y para la acotación de este trabajo ${ }^{120}$.

\footnotetext{
${ }^{119}$ Teniendo en cuenta otros espacios como la literatura, podríamos engrosar esta lista con nombres como Juan de Mena, Juan Álvarez Gato, Diego de Burgos, Rodrigo Cota, Antón de Montoro, Diego de San Pedro, Juan de Flores, Fernando de Rojas, Francisco Delicado, Juan del Encina, Torres Naharro, Sánchez De Badajoz, o Gil Vicente. En el ámbito de la espiritualidad, añadiríamos a los alumbrados conversos Ortiz y Tovar, Juan de Cazalla, María de Cazalla, Los Alcaraz, Los Maluenda, Los Valtanás, Francisco de Osuna o Diego de Estrella. Y, asimismo, a los místicos Juan de La Cruz, Juan de Dios, Juan de Ávila y Teresa de Jesús; o a los relevantes jesuitas conversos Diego Laínez, Juan Alfonso de Polanco, Jerónimo Nadal o Jerónimo Martínez de Ripalda.

${ }^{120}$ Así, las revueltas antijudías de 1391 generalizadas en todo el reino; el reinado de Juan II entre 1406 y 1454 y su importante labor de mecenazgo cultural en la que los judeoconversos fueron muy relevantes; la figura del valido del rey, el condestable de Castilla Álvaro de Luna; la disputa teológica de Tortora en 1412; el Concilio de Constanza (1414-1418); la redacción de los estatutos de la Universidad de Salamanca (1422); la guerra entre Castilla y Aragón iniciada en 1420 y prolongada intermitentemente hasta la Primera Batalla de Olmedo (1445) donde salieron fortalecidos Juan II y su entorno; el Concilio de Basilea (iniciado en 1431 y que duró hasta 1449 con varios cambios de sede); el pogromo antijudío de Toledo de 1449, con la subsiguiente elaboración de los estatutos de limpieza de sangre y la oposición resultante de las élites intelectuales y del papado; el reinado de Enrique IV entre 1454 y 1474; la llamada 'Liga de Alcalá de Henares' en 1461, liga nobiliaria contra el rey, el cual tuvo que hacer concesiones a los nobles dirigidos por Juan Pacheco; la pugna por el reinado de Alfonso, hermano de padre de Enrique IV, que deviene en la 'Farsa de Ávila' de 1465 donde se destrona simbólicamente al rey en pro de Alfonso, lo cual da paso a una guerra civil que, de una u otra forma, no cesará hasta la proclamación de Isabel (Alfonso había muerto en 1468),
} 


\subsection{La cuestión conversa.}

En este punto abordaremos la problemática social y jurídica que supuso la persecución y estigmatización de los judíos y judeoconversos, así como el tremendo peso intelectual del colectivo converso en la historia del pensamiento hispánico en general, y en la conformación del pensamiento político castellano del siglo $\mathrm{XV}$, en particular. Éste último fue determinado por elementos propiamente conversos como la huella del profetismo hebreo y su noción de pueblo, la pervivencia del eschaton en la concepción de la Filosofía de la Historia, la impronta de la filosofía árabo-semítica peninsular medieval, la vocación de creación de comunidad política que sea a la vez comunidad de salvación, o la reivindicación de políticas de inclusión que posibilitaran la convivencia y la participación en la vida civil, demandas éstas resultantes de la propia experiencia de exclusión social encarnada por los conversos y que cristalizaron en el proyecto político de una nación de "cristianos nuevos", cuya inspiración estaba transida de valores republicanos.

Sin embargo, este proyecto político elaborado por los pensadores conversos fracasó, dado que las políticas de persecución a este colectivo lograron bloquearlo y reducir el impacto del pensamiento político converso a finales del siglo XV y principios del XVI. José Luis Villacañas explica así las consecuencias de ello: «La deseable conformación de una base comunitaria quedó reducida a una identidad de homogeneidad católica, y uno de los elementos que pulverizó la posibilidad de ese sedimento comunitario fue que lo republicano se asoció a lo converso» ${ }^{121}$. Esta última frase de la cita previa nos resulta de enorme importancia dado que el autor acerca del cual tratará nuestro estudio de caso (segunda parte de este trabajo), Alonso de Cartagena, era

la otra hermana paterna de Enrique IV como su sucesora al fallecer éste y en detrimento de su hija Juana 'La Beltraneja', cuya legitimidad como hija de Enrique IV se cuestionaba (fue mediante el Pacto de Guisando de 1468 que se ratificó que Isabel fuera la heredera, aunque Enrique IV había de aprobar su matrimonio); el matrimonio secreto en 1469 entre Isabel de Castilla y Fernando de Aragón; la subida al trono de Castilla de Isabel en 1474; la de Fernando al de Aragón en 1479; la constitución de la Inquisición en 1478; el fin de la reconquista en 1492; el decreto de expulsión o conversión forzada de los judíos en 1492; el inicio de la Conquista de América en 1492; la fundación de la Universidad de Alcalá en 1499; o la muerte de Isabel la Católica en 1504, luego de la Felipe el Hermoso y el alejamiento de su heredera Juana I de Castilla del trono, lo que implicó un paso atrás en la influencia de la élite conversa y su proyecto político en la corte (algo que se ve en las fallidas Cortes de Burgos de 1506). En realidad, podría hacerse la acotación de este trabajo en el año 1516, con la coronación de Carlos I de España.

${ }^{121}$ Villacañas (2002): 174. 
converso, y que además fue uno de los principales exponentes de lo que venimos denominando pensamiento político converso - pensamiento político cuyas condiciones de posibilidad estamos desgranando en este capítulo y que, según estamos intentando demostrar a lo largo de esta tesis, lleva a cabo una específica asunción de las ideas republicanas que es propia de Castilla-. Queremos por tanto incidir sobre esta idea que venimos defendiendo de la mancuerna entre esta defensa de los valores republicanos y la élite conversa.

Pese al antisemitismo y la hostilidad creciente contra los conversos, la élite conversa fue aún enormemente influyente aún durante todo el siglo XV — tanto el ámbito intelectual, como en el espiritual y político - y su huella durante los siglos posteriores sería muy profunda. Si, tal y como estamos haciendo, queremos trazar un retrato del contexto filosófico y socio-político de la Castilla del siglo XV, la importancia de la variable conversa en tan grande y tan trasversal que no podemos omitirla. De hecho, nos estamos centrando en este trabajo en lo que hemos llamado pensamiento político converso, denominación en la que incluimos la palabra «converso» no sólo para referirnos al origen de la mayoría de intelectuales que lo conforman este pensamiento político, sino también para recalcar que, precisamente, la circunstancia de ser conversos (sobre todo la vivencia de exclusión y la forma de entender la religiosidad) determinará cómo es el pensamiento político de estos intelectuales y cómo su asunción de los valores republicanos. Una asunción en la que elementos republicanos y religiosos se complementas y retroalimentan. Esto es, cuestiones como la universalidad de la gracia, el bautismo, la idea de cuerpo místico o de comunidad de salvación se politizan entendiéndose como garantes de acceso a la ciudadanía, de restitución del honor, de igualdad y de unidad; en definitiva, como vehículos de inclusión, de posibilidad de participación en el vivere civile y de consolidación de comunidad política.

Hemos de recordar antes de continuar el relevante papel que los judíos habían tenido tradicionalmente en la vida de la corte y de la universidad en Castilla. Ya desde principios de la Edad Media, la contribución política, científica y cultural de los judíos fue importantísima, hasta el punto que no podemos entender a la Castilla medieval sin la fuerte presencia de las élites intelectuales judías. Tampoco, obviamente, sin la incalculable contribución de los intelectuales árabes, aunque, no entraremos aquí en ello por razones metodológicas. Pensemos, por ejemplo, en una figura como Maimónides, o en la brillante labor de la Escuela de Traductores de Toledo. 
A lo largo del siglo XV, los conversos aún ocuparon cargos de relevancia — destacando los médicos - algo esperable dada la alta formación de muchos de ellos. En la primera época de los Reyes Católicos, a pesar de los recelos, para un converso aún era factible la promoción social y profesional. El ostracismo no llegaría hasta finales de siglo. Será unas décadas más adelante cuando la consolidación de los estatutos de sangre conduciría a la inexorable marginación social.

En la figura que mostramos a continuación puede verse que la presencia de comunidades judías, llamadas aljamas, y de comunidades conversas era constante en todo el reino de Castilla.

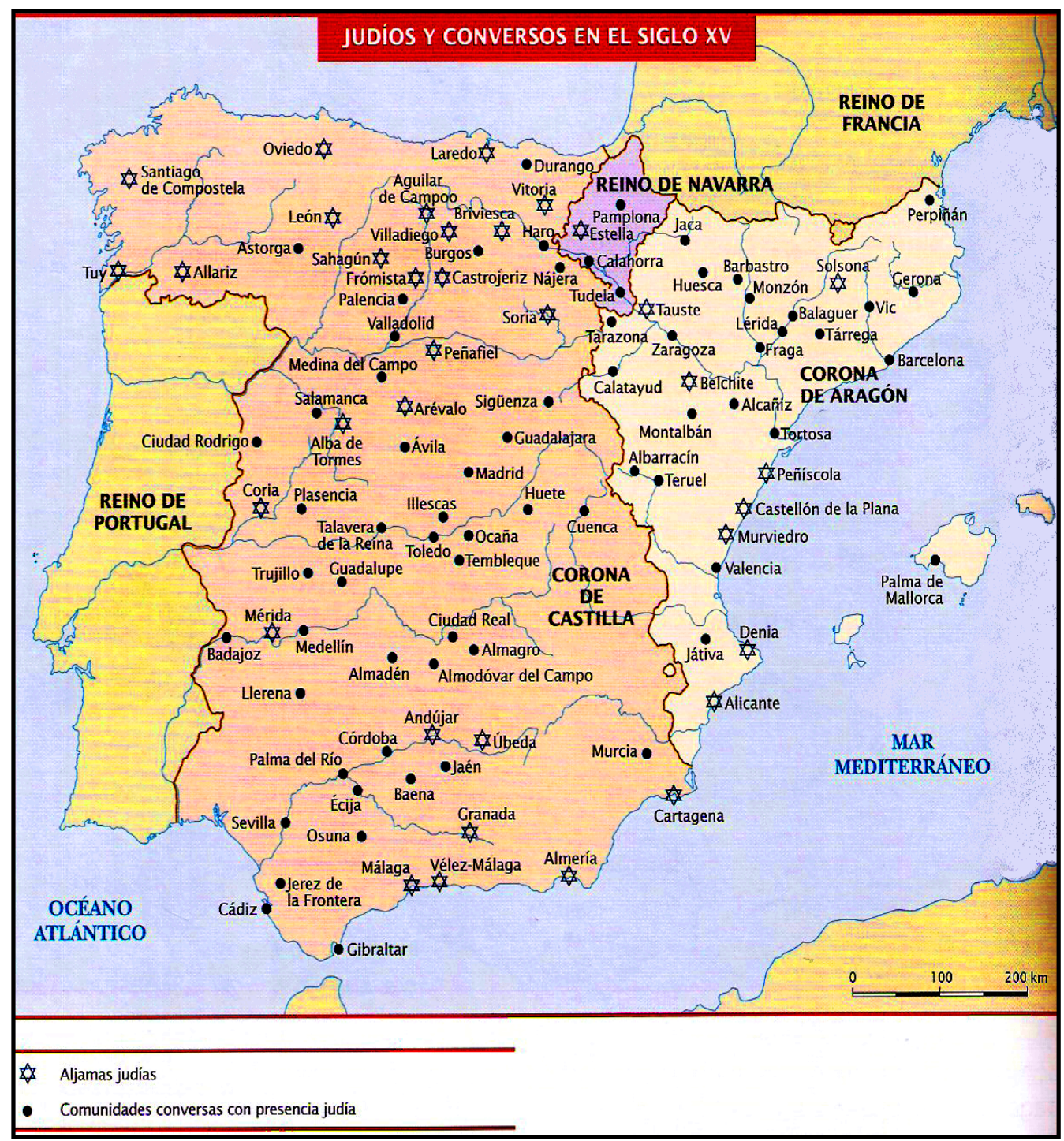

Fig. 1: Judíos y conversos en Castilla, Aragón y Navarra durante el siglo XV. Tomado de García de Cortázar (2005): 248 
El antisemitismo en Castilla (sobre todo entre las clases populares y el bajo clero), se había recrudecido durante en el siglo XIV, y había ido in crescendo hasta llegar a hacerse irrespirable al final de dicho siglo. Eclosionó en hechos como las generalizadas revueltas antijudías de 1391 (fortalecidas, entre otros, por las predicaciones del arcediano de Écija, Fernán Martínez, que luego sería arzobispo Sevilla), que implicaron numerosas conversiones, o la Disputa de Tortosa iniciada en 1413 y en la que se trató de convencer a los judíos, acorralando a sus teólogos, de que su fe era errónea, y consecuencia de la cual hubo también conversiones masivas entre 1413 y 1415. Asimismo, en 1412 Catalina de Lancaster, madre de Juan II y regente de Castilla, había promovido las Leyes de Ayllón, que fueron una suerte de preludio del decreto de expulsión. De acuerdo a estas leyes, entre otras restricciones los judíos tendrían que vivir segregados y llevar una ropa distintiva y no podrían realizar ciertas profesiones, también tenían que recibir obligadamente catequesis católica tres veces al año ${ }^{122}$. Una de las principales figuras del antisemitismo en Castilla fue Fray Alonso de Espina, cuya obra Fortalitium Fidei de 1471, de gran repercusión, recogía mitos populares que vinculaban a los judíos con sacrilegios y brujería.

En 1478 los Reyes Católicos pidieron permiso al Papa para estableces en Castilla el Tribunal del Santo Oficio. El Papa aceptó y dicho tribunal quedó bajo control directo de la Corona. En 1483 pasó a llamarse Consejo de la Suprema y General Inquisición. A diferencia de lo que se piensa generalizadamente, su cometido era juzgar a los conversos (no a los judíos o musulmanes) de los cuales se sospechaba no fueran sinceros cristianos nuevos y cometiesen delito de herética pravedad, esto es, que siguieran judaizando en la clandestinidad. En 1487 Fernando el Católico impulsó el desarrollo de la Inquisición también a Aragón, lo cual en ocasiones se ha visto como un uso instrumental de este tribunal como agente de unificación entre los reinos.

Sin embargo, la situación empeoraría todavía más: en 1483 se decretó la expulsión o conversión de los judíos de Andalucía y en 1486 de los de Zaragoza. Luego llegaría la trágica expulsión de Castilla en 1492: no había más remedio que el exilio o la conversión. Un exilio,

\footnotetext{
${ }^{122}$ Tomo esta información de Suárez (1991).
} 
además, con grandes restricciones económicas acerca de lo que podían llevarse o vender antes de partir, y una conversión que planteaba un serie de duras medidas discriminatorias para los conversos en cuanto a lo financiero, el lugar de residencia, la práctica de oficios, la imposibilidad de participación civil y ostentación de cargos, el acceso a la educación, etc. Sobre los motivos de expulsión existen varias teorías en las que no podemos entrar ahora ${ }^{123}$. Sí reproduciremos un fragmente del propio decreto de expulsión en el que se sugiere que los judíos son una mala influencia para los cristianos al querer inocularles sus ideas y extender su religión herética. Así dice el Decreto de Expulsión. Real provisión de los Reyes para la Corona de Castilla ${ }^{124}$ :

Según es notorio e según somos ynformados de los ynquisidores e de otras muchas personas religiosas, eclesiásticas e seglares, consta e pareçe el gran daño que a los christianos se a seguido e sigue de la participaçion, conversaçion y comunicaçion que han tenido e tienen con los judíos, los quales se prueba que se procuran siempre, por quantas bias e maneras pueden, de subvertir e subtraer de nuestra Santa Fe Catolica a los fieles christianos e los apatar della e atraer e perbertir a su dañada creençia e opininion, ynstruyéndolos en las çeremonias e obserbançias de su ley.

Tanto para la historiografía sefardita como para mucha de la historiografía hispanista, la expulsión de los judíos supuso la anulación de toda modernidad ibérica al inhibir, entre otras cosas, el florecimiento de una burguesía política y económica ${ }^{125}$. Sin embargo, hemos de saber que la expulsión se dio en casi todos los países de Europa (y en la mayoría con anterioridad ${ }^{126}$ ); países que, además, denostaban a una España que consideraban demasiado 'mezclada' — y por tanto 'impura' - , demasiado permisiva con judíos y musulmanes. De hecho, ya en el modelo de sociedad europea planteado en el IV Concilio de Letrán en 1215, se buscaba una sociedad unida en Cristo y sin la presencia de judíos.

\footnotetext{
${ }^{123}$ Para complementar este somero resumen sobre la situación de los judíos y conversos castellanos en el siglo XV y tener más detalles históricos y sociológicos, pueden verse, por ejemplo: Baer (1981), Netanyahu (2000) (2005), Perez (1993) (2012), Alcalá (1995) (2011), Castro (1996) (2013), Benito (2001), Suárez (1991) (1964), Maeso (2001), Blasco (2001), Caro Baroja (1978), Domínguez Ortiz (1949), Mackay (1972), Yovel (2009), Kamen (2013), Gonzalo (2001), o Blasco (2001).

${ }^{124}$ Tomado de Suárez (1964), que lo recoge del Archivo General de Simancas, Patronato Real, leg. 28, fol. 6.

${ }^{125}$ Acerca de las cifras de la expulsión, uno de documentos de la época que lo refiere, la crónica de Bernáldez, estima que se habrían exiliado unos 170.000 judíos. Asunción Blasco (2001), sitúa el número en unos 100.000 exiliados y John Elliot (2005) lo cifra entre 120.000 y 150.000 . En torno a la cantidad de conversos que había en España en el reinado de los Reyes Católicos, calcula Joseph Pérez que serían unos 200.000, Elliot estima, que aproximadamente unos 150.000 (como un 5\% de la población).

${ }^{126}$ En Inglaterra en 1290 (y no se los readmitió hasta 1656), en Francia en 1323, en los diversos principados de Alemania a mediados del siglo XV, y a finales de siglo en Italia (por ejemplo en Parma en 1488 y en Milán en 1490).
} 
En cualquier caso, en lo que queremos incidir ahora es en lo que hizo verdaderamente particular y más complejo el caso español que el de otros lugares: no fue tanto, o no sólo, la expulsión - evidentemente valoraciones éticas al respecto aparte- sino el posterior trato a los cristianos nuevos, a los judeo-conversos. La figura del converso es lo específico del caso hispánico y lo relevante para este trabajo, y dio pie a lo que se conoce como «la cuestión conversa», o «el problema converso». Estos apelativos se refieren al sostenido rechazo, persecución, exclusión y bloqueo para el desempeño de diversas labores del que fueron víctimas los cristianos de origen converso, así como a las consecuencias filosóficas y políticas de esto. Ya a mediados del siglo XX lo hizo notar Américo Castro en su obra España en su historia. Cristianos, moros y judios (1948), y sobre todo en su La realidad histórica de España $(1954)^{127}$. Por tanto, al hablar del problema converso nos referimos a lo siguiente: el que los judíos conversos, pese a ser ya cristianos, siguiesen estigmatizados por su origen étnico, y condicionados por las limitaciones no sólo simbólicas, sino prácticas — dictaminadas por leyes discriminatorias como los estatutos de limpieza de sangre - para el desarrollo de su formación, el desempeño de actividades y la ostentación social de cargos. Parece un gesto propio de la ironía trágica: la posibilidad de la conversión, que no se dio en todos los países de donde fueron expulsados los judíos y que podría parecer un acto de conciliador pragmatismo, acabó complejizando más las cosas y afectando tremendamente a la propia construcción política. La mácula y además su materialización en la imposibilidad de un desarrollo cívico: he ahí la tragedia $^{128}$.

Agravaba la problemática, precisamente, el hecho de que durante todo el siglo XV los judíos habían estado insertos en posiciones de poder político e intelectual (de hecho, durante el reinado de Reyes Católicos, los conversos siguieron en primera línea, aunque luego los monarcas hicieran un viraje, sobre todo Fernando tras la muerte de Isabel), y había que metabolizar, refundir o cambiar esta realidad.

\footnotetext{
${ }^{127}$ Castro (2013) y Castro (1996), respectivamente.

${ }^{128}$ En torno a esto hay muchísima y sugerente literatura, para ampliar información véase, por ejemplo: Alcalá (2011), Castro (2013), Netanyahu (2005), Benito (2001) (1957), Márquez Villanueva (1965), Gilman (1965), Domínguez Ortiz (1949), Benito (2001), Menéndez Pelayo (1995), Asensio (1952), o Beaujouan (1971).
} 
Muchos judíos se marcharon, otros, permanecieron y se convirtieron al cristianismo. Dentro de estos últimos, algunos realizaron una conversión obligada (aunque siguieron "judaizando" clandestinamente, esto es, practicando el criptojudaísmo — son los llamados marranos-), otros tuvieron un proceso de conversión sincera. Sin duda, esta cuestión de la asimilación es harto compleja y daría para otro estudio, pues devino en multitud de ocasiones en una compleja subjetividad dicotómica y en un comportamiento, ya sea de repliegue en lo privado para pasar desapercibido, ya sea de excesiva escenificación del apego a la ortodoxia, todo ello comprensible en quien se sabe perseguido y estigmatizado como maculado ${ }^{129}$. Otra cuestión bien distinta será el caso de los marranos y su resistencia cultural, religiosa y política. De hecho, teóricamente, el nacimiento del Tribunal del Santo Oficio, la Inquisición, fue para prevenir delitos de «herética pravedad», esto es, para prevenir que el criptojudaísmo dentro de los conversos, para evitar que "judaizaran"130. Así lo apuntan estudiosos como Marcelino Menéndez Pelayo, Yitzhak Baer, o Henry Kamen, sin embargo, a partir de investigaciones más recientes como las de Benzion Netanyahu o Ángel Alcalá se ha apuntado que, independientemente de que los conversos lo fueran con sinceridad, parece que la mayoría no judaizaba, por ello, según estos autores, la Inquisición nació por puro antisemitismo, para satisfacer las presiones de los movimientos anti-conversos ${ }^{131}$.

Entre los judíos, sobre todo entre los marranos, sobrevoló una atmósfera de fuerte escepticismo. Esta actitud de descreimiento se perpetró, sobre todo, entre judíos de las clases más ilustradas, pues eran ellos quienes habían tenido más acceso a la filosofía de autores como Averroes y Maimónides. Como indica Yitzhak Baer aludiendo a los judíos vinculados con el ambiente cortesano de Castilla, «El ideario averroísta resultó decisivo en la práctica de muchos campos de la vida social y nacional-religiosa y fue decisivo también en las horas críticas de la historia de los judíos en España» ${ }^{132}$. Esta relación entre ciertos colectivos del mundo sefardita y una crisis religiosa de corte racionalista, hunde sus raíces en las teorías de Américo Castro y es continuada por estudiosos como Julio Caro Baroja, Yitzhak Baer, o Márquez Villanueva, quien

\footnotetext{
${ }^{129}$ Yovel (2009) habla de una «split identity» («identidad escindida») la cual afecta sobre todo a los marranos, aunque tamibén a los conversos.

${ }^{130}$ Recordemos que el delito que técnicamente se perseguía por el Tribunal del Santo Oficio era el de herética pravedad, es decir, deliberado y malintencionado culto herético — sobre todo judaizante- .

${ }^{131}$ Menéndez Pelayo (1981), Baer (1981), Kamen (2013), Netanyahu (2000), Alcalá (2011) .

${ }^{132} \operatorname{Baer}(1981): 192$.
} 
las asocia directamente con el criptoaverroísmo y el neoepicureísmo, y recuerda el repetido lema popular, lleno de escepticismo y desazón, reiterado por los marranos: «No hay sino nascer e morir como bestias» ${ }^{133}$. En esta cuestión de la ligazón entre el judaísmo (y parte del posterior mundo converso) y el racionalismo, Márquez Villanueva, que la encuentra innegable, resalta la vigencia - y aumento - en el siglo XV del perfil de judío "desarrado" para quien fue escrito siglos antes por Maimónides el Morè, esto es, La guía de perplejos (obra que influiría notablemente la Visión deleytable de Alfonso de la Torre, otro texto cumbre del pensamiento converso del XV) ${ }^{134}$. Como describe Pedro de Toledo en la traducción castellana de esta obra de Maimónides, eran éstos «los muy profundos judios sabios en filosofía que auían dubda en sus coraçones, e fuertes turbaçiones de muchas cosas de la santa escriptura que pareçian ser contra naturaleza e razón» ${ }^{135}$. En las aljamas, sobre todo ante el trauma de la expulsión, se mascaba también la sensación de abandono por parte de una Providencia indiferente ante el caos del mundo, se rescataba así el motivo averroísta del Deus otiosus. Frente a esto, el hombre se plantea si él mismo tenía alguna finalidad en un mundo sin orden ni justicia. Este desasosiego se arrastrará hasta la judería de Ámsterdam, llegando a su máxima expresión con personajes como Uriel da Costa o Spinoza ${ }^{136}$.

Aunque había también multitud de cristianos dominados por las mismas dudas, la identificación de este descreimiento se vinculó interesadamente, desde el poder político y religioso cristiano, con el colectivo primero judío, y converso después. ¿Qué mejor herramienta contra ellos que tornarlos chivos expiatorias y acusarlos de ser los causantes de toda la crisis espiritual de que adolecía la Península? Además, esta maniobra favorecía el proyecto político de unidad e identidad hispánica basadas en la religión católica que comenzaría con los Reyes Católicos para seguir con los Austrias Mayores ${ }^{137}$. Personajes como Fray Alonso de Espina se mostraron especialmente duros con los conversos, inculpándoles de profesar un anticristianismo activo y de practicar el llamado criptoaverroísmo, por lo cual se les acusaba de representar un gran peligro para los fieles cristianos.

\footnotetext{
133 Castro (1993), Caro Baroja (1978), Baer (1981), Márquez Villanueva (1993): 277.

134 Maimónides (ed. David Maeso 2015). Acerca de la Visión deleytable, véase Girón-Negrón (2001).

135 Tomo la cita de Márquez Villanueva (2004).

${ }^{136}$ Para complementar información al respecto, véase Albiac (2013).

${ }^{137}$ Acerca de este proyecto político, pueden consultarse Ladero Quesada (1999) o Suárez Fernández (1964).
} 
Tras el edicto de expulsión o conversión de 1492 estaría el sorprendente giro de los Reyes Católicos hacia el partido anticonverso (detrás de lo cual, quizá no haya sólo un ceder a las presiones racistas del pueblo, sino también una oposición a las posturas políticas de cariz republicano de los conversos y una pulsión absolutista de los Reyes Católicos). Además, de fondo estaba el interés por adecuarse al resto de naciones europeas, que presionaban a España para que eliminara su "resto" semítico. Sostiene Joseph Perez: «Con el fin de la Reconquista, España aspira a homologarse con el resto de países cristianos que, desde hace mucho tiempo, no aceptan en su seno más religión que la católica (...) Los reyes no quisieron mantener la originalidad de España en este aspecto. El Estado moderno no estaba dispuesto a reconocer ni el derecho a la diferencia ni la diferencia de derechos en favor de las minorías religiosas» ${ }^{138}$.

Tanto en el campo de la historia intelectual como en el de la sociología y la literatura, se han escrito ríos de tinta y ha habido numerosas polémicas respecto al alcance, la repercusión y las consecuencias de esta problemática conversa: para algunos es la culpable de una lastrada evolución intelectual y política al haber cercenado a la clase pensante, pero para otros el impacto no fue para tanto y creen que se ha manipulado este relato, sobre todo en una construcción del mismo a partir de principios del siglo XX; recordemos por ejemplo, la célebre polémica entre de Américo Castro, defensor de lo primero y Eugenio Asensio en la postura contraria, que contrapone las tesis de Castro en su libro La España imaginada de Américo Castro, de $1976{ }^{139}$. No entraremos en dichas polémicas, pero lo que sí nos interesa apuntar aquí es la relación entre el origen converso de diversos intelectuales de los siglos XV y XVI y su tipo de orientación ideológica, y asimismo, señalar esta impronta conversa en la filosofía hispánica. Estimamos que sí se dan rasgos comunes entre los distintos pensadores conversos de la época — ya sea por su matriz cultural e intelectual, ya sea por su reacción al estigma y la persecución, ya sea por querer frenar lo que consideraban leyes y políticas arbitrarias y que denotaban un uso desmedido de la autoridad, ya sea por una vocación de conformar una comunidad política cohesionada, ya sea por su vocación cívica, ya sea por un afán de mantenerse cerca del poder y por no desprestigiarse, o tal vez sólo por una solidaridad emergida su propia supervivencia-. Pensamos por ello que es cabal hablar de pensamiento político converso como una herramienta analítica para englobar

\footnotetext{
${ }^{138}$ Perez (2012): 38.

${ }^{139}$ Castro (1996).
} 
estas características comunes a un grupo de intelectuales (incluso algunos de los cuales no eran conversos, pero eran afines a sus círculos y empáticos con su circunstancia y sus reivindicaciones como cristianos nuevos). Nos referimos a pensadores como los que ya enumeramos en la introducción de este capítulo.

Como indica el experto en el tema converso, Ángel Alcalá, se da una peculiaridad existencial e intelectual de los conversos, y en la medida en que se tenga en cuenta esta realidad se podrán comprender «los fundamentos del propio ser histórico español» ${ }^{140}$. Afirma este estudioso $^{141}$ :

El puente real entre cultura española judía y cultura española cristiana fue el alzado por los judeoconversos (...) Lo que Américo Castro y luego Benzion Netanyahu, en diferente pero complementario nivel, han delimitado como identidad judeoconversa debe ser puesto constantemente de relieve, y ello por dos razones: para destacarlo como hecho histórico específicamente español, pues no hay ningún otro país europeo que pueda mostrar tal simbiosis; y para subrayar que la contribución máxima de la etnia judaica a la cultura y sociedad españolas (...) no fue ya obra de judíos propiamente dichos, sino de judeoconversos.

Claro está que cuando agrupamos a estos pensadores bajo un mismo rubro no pretendemos homogeneizar el pensamiento de cada unos de ellos y conceptualizarlos unívocamente, sino recalcar sus características comunes y específicas para poner en valor su contribución al pensamiento hispánico y, concretamente a la filosofía política hispánica y a la implementación de valores republicanos en el ámbito hispánico. Expresa en relación con esto el profesor italiano Guido Cappelli ${ }^{142}$ :

Parece que un número interesante de intelectuales del siglo XV fueron conversos. El dato está ahí, y nos interpela, nos pregunta encarecidamente por la relación entre la condición conversa y una cierta inspiración literaria y cultural (...) La cultura conversa, en la Castilla anterior a los Reyes Católicos, es mediadora cultural privilegiada de la cultura humanística italiana (...) Los conversos buscan un nivel paritario de partida entre clasicismo y cristianismo.

\footnotetext{
${ }^{140}$ Alcalá (2011): p. 13.

${ }^{141}$ Alcalá (2011).

${ }^{142}$ Cappelli (2014): 1, 2, 11.
} 
Lo que parece evidente es que el trato discriminatorio a los conversos en Castilla suscitó una fuerte y alineada reacción intelectual, sobre todo por parte de los propios intelectuales conversos (aunque no sólo por ellos). Detonó un potentísimo florecimiento filosófico que reflexionaba sobre tal circunstancia y su carácter injusto y arbitrario, sobre el abuso del poder al acometer tal persecución, sobre las nociones de comunidad, exclusión y convivencia, etc. Este pensamiento converso acabaría tornándose antagonista de la cultura oficial impuesta. Concordando con lo expuesto en los párrafos previos $-\mathrm{y}$ con lo que venimos defendiendo a lo largo de todo este trabajo acerca de lo apropiado de hablar de un pensamiento político converso - el estudioso Fernando Miguel Pérez Herranz, en un libro reciente, hablará de un «humanismo hispano-converso». Queremos destacar la siguiente cita suya, que nos permitimos sea tan extensa por su enorme pertinencia en esta dirección y por haber hallado al encontrarla ya al final de la redacción completa de esta tesis doctoral - una estimulante coincidencia con nuestra postura a lo largo de la misma, así como un respaldo para nuestras afirmaciones ${ }^{143}$ :

Las fuentes de inspiración fueron Pablo de Tarso, por su confrontación con la vieja Ley, y también los estoicos, en quienes ellos mismos [los conversos] se veían reflejados. Sobre todo en Séneca, una especie de versión laica sus doctrinas: defensa de la Gracia frente a la Ley; exaltación del individualismo frente al rito; defensa de la religión orientada hacia una eticidad autónoma, aunque vinculada a los ritos y ceremonias judías. Séneca y Cicerón fueron impulsados por el proyecto de cristianización de Benedicto XVIII tanto en el reino de Castilla como en el Aragón. Los hispano-conversos aceptaron las fuentes clásicas (Platón y Aristóteles) compatibles con la tradición del cristianismo bíblico; asimilaron el pensamiento republicano de Cicerón; defendieron el concepto de «cuerpo místico castellano»; propusieron un pacto interracial que concordara las culturas hidalga y judía (...) Todos ellos buscaron un modelo de convivencia política y de costumbres, un ethos que diera un giro a las guerras y a la desolación de los reinos peninsulares. Los hispano conversos vincularon el ethos personal del cristianismo al ethos político de los ciudadanos, un proyecto que cristalizó Alonso de Cartagena. (...) Una conciencia ética que caracteriza a la modernidad, de la que paradójicamente ha sido excluida España (...)

Tal y como apuntábamos arriba, en lo que queremos incidir nosotros es en la importancia de los conversos en el desarrollo del pensamiento filosófico propiamente hispánico. Como muy bien se preguntaba Américo Castro retóricamente «¿Cómo quedaría el pasado intelectual español

${ }^{143}$ Pérez Herranz (2016): 264-265. 
si le sustrajésemos los nombres conversos? ${ }^{144}$. Y uno de estos rasgos que defendemos como propios de estos pensadores conversos es el cómo introyectaron las ideas republicanas, y como las amalgamaron con lo religioso y con su anhelo de una racionalidad política inclusiva frente a las dinámicas de exclusión. Valores republicanos como la posibilidad de participación; la noción de servicio público en pro el bien común; la necesidad de la existencia de una base comunitaria, esto es, de un cuerpo social cohesionado (sin exclusiones), que ejerciese como comunidad política; la idea de los precisos límites a la autoridad; o la noción de libertad como no dominación. De hecho pensamos que podemos hablar de un "republicanismo converso" en la Castilla del XV, pues es claro que cabe preguntarse por la ligazón en entre una sensibilidad republicana y el factor converso. De ahí que podamos también hablar de pensamiento republicano converso, como el objeto de este trabajo. En Castilla, las ciudades, las Cortes y las aulas fueron los espacios donde materializar estos valores pactistas y republicanos, y no es casualidad que en dichos ámbitos estuviese muy presente - y tuviese un papel rector - una élite letrada conversa. Ésta defendía, además, un cristianismo en el que convergieran virtudes del pensamiento clásico con las virtudes cristianas. Tampoco es casual que el mesianismo y el profetismo hebreos — sus nociones de líder, de pueblo, de comunidad - reverberasen en estos conversos y determinasen su teología política y su concepción de la monarquía. Asimismo, la tradición tomista de estos intelectuales conversos escolásticos, hacía que en su visión política estuviesen bien presentes ideas iusnaturalistas, en lo referente, por ejemplo, al origen de la autoridad, o en al derecho subjetivo, esto es, a la susceptibilidad de ser toda persona portadora de ciertos derechos inalienables, derechos propios del Derecho Natural, pese a ser de otra religión o "infiel". Autores como Pedro de Osma o Fernando de Roa defendieron la preeminencia de este Derecho Natural independientemente de las creencias religiosas de la persona.

Muy acertadamente, el estudioso Enver Torregroza habla de la contribución de los conversos a la interpretación racional de la ley revelada cristiana, pues lo que él llama racionalismo converso fungió como puente entre el judaísmo y el cristianismo. Este racionalismo converso, de corte aristotélico, contribuyó a la integración entre lo espiritual y lo temporal propia de los conversos castellanos, y en este sentido fortaleció el tomismo. Escribe Torregroza que los conversos logran «una redefinición de la visión cristiana de la política (...)

\footnotetext{
${ }^{144}$ Castro (1996).
} 
una valoración positiva del reino del hombre», y señala que esta valoración positiva y de integración entra la ciudad -en sentido republicano- y la Ciudad Fiel, fue gracias a conversos como Pablo de Santa María y su hijo Alonso de Cartagena ${ }^{145}$.

Como sugiere el profesor José Luis Villacañas, el pensamiento converso implicaba también una traductibilidad práctica, esto es, un proyecto político, teológico y cultural desde el que organizar la difícil convivencia y promover la participación cívica, un proyecto que él describe como una nación de cristianos nuevos, y que había de ser liderada por las élites conversas (donde destacaban Alonso de Cartagena y su círculo) ${ }^{146}$. Sin embargo, finalmente se impuso el criterio anti-converso (que además de una férrea doctrina oficial en lo religioso, en lo político era mucho más cercano a presupuestos de inspiración absolutista): la persecución a los conversos, las leyes de segregación por origen, la Inquisición, el decreto de expulsión y finalmente el fracaso de la revolución comunera en 1521, son pruebas de que el proyecto político de personajes como Alonso de Cartagena, El Tostado, Pedro de Osma no se consolidó como agenda política.

El programa integrador del círculo más próximo a Alonso de Cartagena (conformado por figuras como Diego Valera, Fernando del Pulgar, Alonso de Palencia, Rodrigo Sánchez de Arévalo, etc.), lamentablemente no llegaría a ejecutarse, pese a que, como hace notar Pérez Herranz, «Alonso de Cartagena no abogaba sólo por una tolerancia o una aceptación, si no por la resolución de problemas desde la dimensión política» ${ }^{147}$. Y además, como consecuencia de lo anterior, aconteció, como también señala este estudioso, «(...) el fracaso de una fílosofía del sujeto en intercomunicación con las otras religiones»» ${ }^{148}$.

Estos conversos actuaron defensivamente contra medidas como la Inquisición (la cual, según estos conversos, era lo verdaderamente herético al querer fragmentar la unidad de la Iglesia e ir en contra de la universalidad cristiana, defendida ya desde Pablo), o contra medidas

\footnotetext{
145 Torregroza (2010): 187. Véase también al respecto Torregroza (2008).

146 Villacañas (2008): 532.

${ }^{147}$ Pérez Herranz (2016): 305.

${ }^{148}$ Pérez Herranz (2016): 329.
} 
como los estatutos de limpieza de sangre de $1449^{149}$.

Para demostrar que esta discriminación era una arbitrariedad y una injustica que no podía sostenerse ni teológica, ni política, ni moralmente - una experiencia de daño que determinaría también de una nueva subjetividad perpleja, menesterosa, quebrada, vulnerable, dialógica, como dice Yimiryahu Yovel, una «identidad escindida» ${ }^{150}$ - muchos de los pensadores castellanos desplegaron un dispositivo filosófico de impresionante calidad. Emplearon con sofisticación y rigor argumentos jurídicos, teológicos y de teoría política que nos han quedado como potente arsenal de ideas que recuperar. Como lúcidamente reflexiona Alcalá: «A la larga la Inquisición logró su propósito de asimilar a los judeoconversos, pero con el paradójico resultado, que los inquisidores y los Reyes Católicos no pudieron prever, de que los conversos imprimieran a los cimientos de la emergente sociedad y cultura españolas cristianas, que ya eran las suyas, ciertos signos de identidad que la caracteriza» ${ }^{151}$. Este dispositivo intelectual converso realizó una tremenda labor intelectual en aras de elaborar una racionalidad política y teológica basada en la inclusión y la unidad, y en aras de construir toda una teoría de acceso a la ciudadanía atravesada de republicanismo de la que aún hoy podemos tomar y aprender mucho. Y, de hecho, pensamos, como venimos afirmando en este texto, que este pensamiento político converso es en realidad el que encarnó mejor el pensamiento político castellano del siglo XV, el que lo dotó de su especificidad. Es ahí justamente donde encontramos el Defensorium Unitatis Christianae, texto que nos ocupa, y, como explicaremos, escrito precisamente en 1449.

De todos modos, salve decir, que en la Castilla del momento muchos justificaron la expulsión, con Fray Alonso de Espina como uno de sus referentes doctrinales, asevera el estudioso Miguel Anxo Pena a colación ${ }^{152}$ :

(...) la expulsión de los judíos que, lejos de ser únicamente algo promovido por la Corona, tenía un fuerte respaldo social, que es el que realmente justificaría el proceder de esta determinada manera. A este respecto puede ser suficientemente ilustrativo acercarse a la realidad teológico apologética de la época, donde infinidad de autores mantienen

\footnotetext{
${ }^{149}$ Dice Pablo en Gálatas 3, 28: «No hay judío o griego, no hay siervo o libre, no hay varón o hembra, porque todos sois uno en Cristo".

${ }^{150}$ Yovel (2009).

${ }^{151}$ Alcalá (2011): 13, 14.

152 Pena (2008): 19, 20.
} 
obras atacando y apoyando directamente una intervención contra este tipo de grupos socio-religiosos minoritarios, justificando siempre sus posturas desde un contexto de catolicidad. Musulmanes y judíos habían sido y seguían siendo una dificultad para la convivencia que, progresivamente derivaba hacia conflictos también en lo doctrinal.

Por ello también hay quienes han pensado que todas estas cuestiones se han sobredimensionado, así el estudioso Peter Edward Russell, quien dudó de que los intelectuales conversos se arriesgasen en adoptar posturas radicales al respecto ${ }^{153}$. Sin duda, pensamos que sí se arriesgaron, casi heroicamente, y lo hicieron desde el rigor de la buena argumentación, así se confiesa al respecto el propio Alonso de Cartagena en el Defensorium unitatis christianae: «En aquella oportunidad en que me tomé la tarea de escribir estas cosas para aplastar en su mismo nacimiento el error que algunos se esforzaban por introducir, y del que nació el tratado (...) ha sido la flaqueza de mi pluma la que ha podido refutar lo que intentaba romper la indivisibilidad de la unidad cristiana», o, en otro momento: «Por esto, únicamente mi pluma me obliga a escribir para que no calle lo que todo el mundo ve, y la lengua me empuja a que hable para que no sea que, callando, parezca que no he prestado la debida atención o que lo he pasado por alto intencionadamente» ${ }^{154}$. Precisamente él es uno de los máximos exponentes de este esfuerzo, de este pensamiento político converso sobre el que trata esta tesis, y en él nos centraremos en los capítulos 3 y 4 de este trabajo, donde, también analizaremos dicho texto, que entendemos como su obra cumbre.

Acerca de la valiosa labor que los intelectuales conversos —así, Alonso Cartagenahicieron para combatir el racismo y la exclusión, y para fortalecer la identidad conversa, dándole además consistencia y justificación teológica, tomamos estas lúcidas palabras de Stefania Pastore sobre Cartagena y el jerónimo Fray Alonso de Oropesa ${ }^{155}$ :

\footnotetext{
${ }^{153}$ Russell (1973).

${ }^{154}$ Cartagena (1993): 381 y Cartagena (1993): 281. Nos referimos a la edición y traducción de Verdín-Díaz editada en 1993.

${ }^{155}$ Pastore (2004): 26. La traducción es nuestra, el texto original es: "La riflessione di Cartagena e Oropesa segnava così un momento fondamentale all'interno della storia della spiritualità spagnola, riproponendo un ampio arsenale di idee, immagini, passi testamentari a cui i conversos castigliani potevano attingere (...) Offrivano ai cristiani nuovi la possibilità di costruire la propia identità conversa (...) Nell'accentuazione di alcuni passi di Paolo e di Giovanni, nell'idea di una fede come illuminazione di fronte alla quale ogni altra differenziazione umana veniva a cadere, si offriva ai nuovi convertiti la possibilità di una radicale palingenesi (...)".
} 
La reflexión de Cartagena y Oropesa marcaba así un momento fundamental en el interior de la historia de la espiritualidad española, proponiendo un vasto arsenal de ideas, imágenes, pasajes testamentarios a los que los conversos castellanos podían recurrir $(\ldots)$ Ofrecieron a los nuevos cristianos la posibilidad de construir su propia identidad conversa (...) En la acentuación de algunos pasajes de Pablo y Juan, en la idea de la fe como iluminación ante la cual cualquier diferencia humana se desvanecía, se les ofrecía a los nuevos conversos la posibilidad de una palingénesis radical (...)

\subsection{La función social del letrado.}

La figura del letrado fue vital en el desarrollo cívico de la Castilla del siglo XV, a éste lo podemos entender como una suerte de intelectual orgánico con vocación de servicio público en pro del bien común y con un ethos que liga el conocimiento no a la contemplación, sino a la filosofía práctica, es decir, a la búsqueda de la virtud en la vita activa, un ethos embebido de la influencia de autores como Cicerón, Séneca o la ética aristotélica. Esta nueva clase intelectual, la de los letrados — casi siempre con formación como juristas - que actuaban como consejeros en la corte o que ostentaban cargos municipales, eclesiásticos, corporativos o universitarios, estuvo mayoritariamente habitada por conversos. También por nobles, los cuales materializaron el tópico del equilibrio entre armas y letras y que hicieron que la corte fuera también un espacio donde trenzar, en palabras de Cappelli: «una alianza intelectual pero también política: humanismo, ética y Estado» ${ }^{156}$.

Este tipo humano del letrado abundó en la universidad, en la corte y en el clero, y su modelo permeó en Castilla incluso a la fundamental noción de honor (ligada indisolublemente a la de virtud), pues para el letrado el honor y la virtud civiles se alcanzaban a través de la idea servicio público: así, esta noción del honor, vertebral en el pensamiento hispánico, se redirige de lo individual hacia lo común y lo patriótico. En relación con este ideal del justo porcentaje entre armas y letras para los nobles (que ahora serán a la vez letrados y caballeros, tema que no es baladí dada la importancia que en la cosmovisión castellana tenía la figura del caballero), es importante recordar que no se refiere la parte de "letras" de este binomio a una erudición despegada de la praxis: al contrario, está implícito el objetivo de ilustrarse con un fin práctico; ya no hay que ser sólo 'hombre sabio', sino 'hombre bueno', y esta moralidad práctica se aplica en

\footnotetext{
${ }^{156}$ Cappelli (2014): 2.
} 
la virtud ciudadana. Apunta Fernández Gallardo — haciendo alusión a cómo Alonso de Cartagena entiende la función del caballero en su Doctrinal de caballeros (de 1487)—: «Su reflexión sobre la caballería presenta una acusada orientación ética (...) El «ethos» caballeresco tradicional recibe, así, la contestación desde los presupuestos culturales de los letrados que iban a servir eficazmente a la fundamentación ideológica de la nueva realidad política, el Estado Moderno» ${ }^{157}$. La dignificación en la sociedad se lleva a cabo a través de la condición de servidor público.

Ha de reseñarse la pulsión de intercambio y creación de sinergias (o de sugerentes espacios de debate) de estos intelectuales con sus coetáneos del resto de Europa, algo que permitía en tiempo real, por ejemplo, la llegada de las ideas del Quattrocento al cuatrocientos castellano. Así, por ejemplo Pier Candido Decembrio — colaborador en la culturalmente vibrante corte de Alfonso V el Magnánimo en Nápoles, y por tanto muy cercano a Aragón y leído, por ende, en Castilla - mantuvo, al igual que Bruni, una fluida correspondencia con Alonso de Cartagena. Estos letrados estaban en constante diálogo y participaban de la vanguardia intelectual de su época: se nutrieron del tomismo de la Universidad de París, fueron parte activa de los concilios (visitados por castellanos como Juan de Segovia o Alonso de Cartagena), constituyeron misiones diplomáticas (pensemos en las acometidas por hombres como Diego de Valera o el propio Cartagena), pasaron periodos en cortes extranjeras, etc. La retroalimentación de conocimiento estaba asegurada.

Asimismo, es interesante resaltar la dimensión política de estos letrados como intermediarios y legitimadores de la institucionalidad monárquica (así fue en la mayoría de casos, salvo excepciones como Alonso de Madrigal o Alonso de Castrillo). No queremos decir con esto que su tarea fuese hacer propaganda sin más del poder real o promover su poder indiscriminado, al contrario. La cuestión tiene un sugerente pliegue: el ideal de monarca que ellos legitimaban y reproducían era un modelo que ellos mismos habían diseñado, un modelo de gobierno mixto en el que la autoridad real era limitada por el sistema de Cortes y por el control jurídico (en línea con las ideas iusnaturalistas, constitucionalistas, conciliaristas y con la larga

${ }^{157}$ Fernández Gallardo (2002): 374. 
tradición Alfonsina castellana) ${ }^{158}$. Además, las Cortes condensaban las aspiraciones de las élites letradas castellanas, formadas fundamentalmente por conversos, los cuales, además, habían logrado en muchas ocasiones llegar a ser élites dirigentes de las ciudades. Esa idea príncipe renacentista atravesada por el organicismo y con rasgos republicanos que, como veremos más adelante, operó en Castilla un leve pero intenso tiempo, fue articulada, precisamente, por estos letrados, es más: ellos eran depositarios del conocimiento de la virtud y encargados de transmitirla tanto al pueblo en general como al propio monarca (no pasemos por alto, por ejemplo, la tremenda importancia que tuvieron los espejos de príncipes). Dichos letrados, que tenían autoconciencia de grupo, de élite ilustrada, eran sabedores de su papel de apoyo a los gobernantes al servirles como asesores y como solventes orientadores ético-políticos. Como hace notar Luis Fernández Gallardo, muchos juristas castellanos se veían urgidos por el servicio a la institución monárquica, encarnada en el Consejo Real, apunta este estudioso que desde la universidad había una «fuga de cerebros» hacia la administración ${ }^{159}$. Al respecto opina Guido Cappelli ${ }^{160}$ :

Había que estar dispuestos a la innovación y a la renovación: nada mejor que toda una clase social e intelectual en busca de legitimación y de prestigio. Es así como se fraguó este extraordinario debate de ideas que conformó, allá por la segunda mitad del siglo XV, la época más fecunda del humanismo en tierras castellanas, el de los tiempos de Juan II y Enrique IV, cuando la crisis, la transición, el desorden, favorecen la experimentación, la búsqueda y la redefinición de un nuevo marco de convivencia, una nueva forma de relación con el poder y de éste con el mundo.

Es destacable la contribución que estos letrados hicieron al pensamiento político castellano y sus aportes críticos reivindicando un ejercicio virtuoso y no arbitrario de la autoridad por el gobernante. Ha de mencionarse también que mantuvieron cierta vocación de independencia, lo cual, sin embargo, no implicaba necesariamente romper con la institucionalidad, hecho éste impensable, por otro lado, dada su propia formación, su vocación de servicio público en pro del bien común, y su necesidad de subsistencia material, y hecho que hemos de tener en cuenta al aproximarnos a su producción textual.

\footnotetext{
${ }^{158}$ Acerca de esta tradición jurídica Alfonsina, véase Nanu (2013) y Rodríguez Velasco (2013).

${ }^{159}$ Fernández Gallardo (2002): 67.

${ }^{160}$ Cappelli (2014): 2.
} 


\section{3 “La Primera Escuela de Salamanca”. Escolástica y pensamiento político.}

El abordar el pensamiento político castellano en los siglos XV y XVI nos conduce de inmediato a la Universidad de Salamanca. El papel de esta institución fue crucial como motor de pensamiento teológico, jurídico y político renovador. Es más, podríamos decir, con el estudioso Anxo Pena, que su papel es fundacional del pensamiento hispánico; asevera incluso este experto, refiriéndose a la conocida como Escuela de Salamanca vinculada a esta universidad: «Lo más apropiado no sería hablar de Escuela de Salamanca, sino de pensamiento hispánico, entendiendo por tal aquél que tiene su dependencia de origen en Salamanca» ${ }^{161}$. Un pensamiento hispánico y una tradición intelectual que tuvieron por bandera - con un notable rigor y dedicación intelectual para explorar en la herencia doctrinal, el iusnaturalismo y el pensamiento político clásico- el aplicar las grandes cuestiones teológicas y jurídicas para resolver los problemas socio-políticos circundantes ${ }^{162}$.

En este punto queremos recordar la tremenda importancia que este centro tuvo en la conformación del pensamiento político del siglo XV, relevancia aún bastante poco visibilizada en la historia intelectual y en la historia de la filosofía política. En los últimos años se están realizando interesantes avances académicos en torno a las contribuciones filosóficas y jurídicas de la Universidad de Salamanca en el siglo XV. Por ejemplo, hemos de destacar los libros $L a$ Primera Escuela de Salamanca (1406-1516) — resultante de un congreso homónimo celebrado en 2011 en la actual Universidad de Salamanca, libro coordinado por Cirilo Flórez y en el cual se recogen valiosos artículos al respecto y se propone la denominación Primera Escuela de Salamanca- y La Universidad de Salamanca en el primer Renacimiento, 1380-1516, trabajo éste de Luis Enrique Rodríguez-San Pedro ${ }^{163}$. Nos interesa recalcar cómo las aulas de Salamanca fueron aglutinante y potenciador en Castilla de realidades tan definitorias para nuestra investigación como la conformación de una intelectualidad conversa, la formación de los letrados, la nueva lectura del aristotelismo político, el conciliarismo, el interés y desarrollo de valores republicanos, el pre-erasmismo y el iluminismo religioso, el organicismo en la teoría del

\footnotetext{
${ }^{161}$ Pena (2009): XV Este punto lo discute, sin embargo, Ignacio Jericó Bermejo (2012) en su artículo “Escuela de Salamanca y Pensamiento hispánico? ante una propuesta”.

${ }^{162}$ Para ampliar información acerca de la historia, la orientación y la importancia de la Universidad de Salamanca, véanse Pena (2008) y (2009), Rodríguez-San Pedro (2014), (2006), (1995) у (1991).

${ }^{163}$ Flórez (2012) (coord.) Rodríguez-San Pedro (2014).
} 
principado, o la recepción del iusnaturalismo tomista y su aplicación a cuestiones políticas apremiantes en el momento, así como la contribución de esta Primera Escuela de Salamanca a la Filosofía del Derecho ${ }^{164}$.

Entre los muros de esta universidad se consolidó lo que venimos llamando a lo largo de este trabajo pensamiento político converso. Afortunadamente, el inmenso legado de la conocida como Escuela de Salamanca (esto es, la desarrollada en el siglo XVI, y la cual en mucho es heredera de la del siglo XV), ha sido más reconocido, sobre todo los aportes de pensadores como Francisco de Vitoria, aunque aún queda mucho por hacer al respecto, pues como indica María Martín, además de cuestiones como la Leyenda Negra o la invisibilización fuera del ámbito hispánico de la filosofía política hispánica, está otro problema interno: «(...) el problema de la propia historiografía española, que a veces no ha mirado al siglo XVI de una forma objetiva y ha estudiado la Escuela de Salamanca para reforzar el patriotismo del Imperio español, haciendo apología de valores que no son los de la Escuela de Salamanca» ${ }^{165}$. El reto es poner en valor dicho pensamiento político, algo que este año, gracias a iniciativas como la conmemoración de los ochocientos años de la fundación de la Universidad de Salamanca se está haciendo.

Este centro educativo durante el XV fue de marcado corte escolástico, heredero del tomismo medieval, algo perfectamente compatible y complementario con el desarrollo de ideas republicanas, tal y como ya expusimos en el punto 1.2 del capítulo previo (titulado «El concepto humanismo. Problematización del término para este trabajo. Una lanza a favor de la escolástica.»). Como explica el experto en la historia de esta universidad, Luis Enrique Rodríguez-San Pedro ${ }^{166}$ :

El método pedagógico comprendía «lectiones», «repetitiones» y «disputationes», como en el resto de las universidades europeas del momento. Se trataba de comentarios analíticos sobre textos consagrados, conferencias magistrales públicas y ejercicios dialécticos. La lengua académica era el latín, lo que facilitaba los intercambios y la movilidad internacional. Las autoridades de referencia eran el derecho civil romano justinianeo («corpus iuris civilis») o el derecho pontificio medieval («corpus iuris

\footnotetext{
${ }^{164}$ Véase acerca de a esto último Schambeck y Hermida del Llano (2012), y Franz Koeck y Hermida del Llano (2012).

${ }^{165}$ Martín (2018).

${ }^{166}$ Rodríguez-San Pedro (1991): 11 y 12.
} 
canonici»); así como los clásicos grecolatinos y Aristóteles (...) Por ello, a lo largo del siglo XV, Salamanca se configura como una universidad tradicional, dentro del sistema romanista y canónico

Su Constitución de 1411 la pone en sintonía con universidades como la París, Bolonia u Oxford, y en 1422 el Papa Martín V reelabora los estatutos de la Universidad de Salamanca, consolidando los estudios en filosofía práctica, que en Castilla se articulará, en búsqueda de soluciones, con la problemática de convivencia entre razas y $\operatorname{credos}^{167}$.

Cirilo Flórez Miguel explica que dentro de la universidad y a lo largo del siglo XV cohabitan tres grandes líneas de pensamiento, siendo la primera la que más nos atañe ${ }^{168}$ :

La línea escolástica en la que destaca el «humanismo tomista» de los profesores de artes y la aplicación del método de Tomás de Aquino en los estudios teológicos; la línea del humanismo filológico, en la que de la mano de Nebrija (...) triunfa el humanismo moderno; y finalmente la línea de los renovadores de los estudios de artes, con la entrada del nominalismo de la mano de Silíceo y la cristalización de la renovación de los saberes en los famosos Estatutos de 1529, siendo rector Pérez de Oliva. Con estos últimos se cierra el ciclo de renovación que se corresponde con la que hemos denominado Primera Escuela de Salamanca.

Dentro del corpus de fuentes y autoridades más discutidas en la Universidad de Salamanca, estaban obviamente la Biblia y la Patrística, así como las sumas, glosas y comentarios elaborados por autores medievales como Tomás de Aquino, Duns Escoto, Guillermo de Ockham, Marsilio de Padua o Juan Gerson. También se seguía a autores clásicos, destacando Aristóteles, Cicerón o Séneca, y a ambos cuerpos del Derecho, el civil (tomado sobre todo del derecho romano, esto es, del Codex y el Digesto, que formarían parte del Corpus Iuris Civilis recopilado en tiempos de Justiniano y en las que se recogía el trabajo de juristas como Ulpiano, Marciano o Gayo; aunque también se tenía en cuenta la tradición del derecho castellano) y el canónico (Corpus Iuris Canonici tomado sobre todo de la Glosa Ordinaria, el Decreto de Graciano y los textos de Bartolo de Sassoferrato ). Estas fuentes servían de insumo para abordar y discutir cuestiones como la potestad y el origen de la autoridad regia, la relación entre la corona y el papado, la idea de comunidad política —a partir de las teorías

\footnotetext{
167 Tomo esta información de Pérez Herranz (2016): 273.

${ }^{168}$ Flórez (2012): 11.
} 
conciliaristas - la posibilidad y pertinencia de poner límites a la autoridad, la pertinencia de la participación política o debates más concretos acerca de los problemas de convivencia propios de la Castilla del XV.

Sin duda, en el espectro ibérico de los siglos XV y XVI la escolástica vivió un momento de esplendor y de altísima calidad, como hace notar Francisco Quijano, con cuyo enfoque coincidimos. Ésta destacaría por adoptar, desde su revaloración del tomismo, un pensamiento político que podríamos considerar fuertemente constitucionalista $\mathrm{y}$, en algunos casos, republicano $^{169}$. La teología política desarrollada en la Universidad de Salamanca - tanto su método como su cosmovisión - es constitutiva del pensamiento castellano de los siglos XV y XVI, es decir, es vital en la conformación de éste, y no es posible por ello escindir escolástica y pensamiento político castellano de ese momento, y, por ende, no es posible tampoco hablar para Castilla de una filosofía de la historia secular ligada al resurgir de valores republicanos (como vimos, asimismo, en el capítulo previo en nuestra crítica al concepto de humanismo cívico y a su no aplicabilidad al caso castellano). De ahí que vengamos sosteniendo en esta tesis que la recuperación del republicanismo clásico en Castilla convive con la escolástica y con una filosofía de la historia escatológica, y es más, que afirmemos que este republicanismo castellano se nutre de su articulación con el cristianismo - articulación en la que la idea de comunidad cristiana y comunidad política se engarzan y en la que teleología de la salvación y teleología de la virtud cívica se alinean-.

Por razones metodológicas no nos es posible aquí detenernos ampliamente en las figuras más relevantes que fueron docentes en Salamanca (y aún menos en sus alumnos ilustres, pues lo son casi todos los nombres castellanos que aparecen en esta tesis), pero es de justicia mencionar al menos a parte del elenco de profesores de esta universidad. Hemos de destacar a personajes como Alonso Fernández de Madrigal 'El Tostado' y a sus discípulos Fernando de Roa y Pedro Martínez de Osma, los tres claves en la relectura de Aristóteles - en la misma dirección de la que en Italia lo hacían Salutati o Bruni, es decir, haciendo hincapié en su filosofía práctica— ${ }^{170}$. Los textos castellanos de entonces en los que la crítica ya ha señalado con más intensidad la

\footnotetext{
${ }^{169}$ Quijano (2017): 85.

${ }^{170}$ Para ampliar información al respecto, véase: Fernández Vallina (2012), sobre Alonso Fernández de Madrigal; Labajos (2012) y Flórez (2007) sobre Fernando de Roa y Pedro de Osma, y Rivera (2012) sobre Juan de Segovia.
} 
herencia republicana son los producidos por la corriente aristotélica liderada por Alonso Fernández de Madrigal, en la senda de sostener que la perfección moral se alcanza en la práctica civil. Su De optima politia, de 1436, plantea el democrático como sistema óptimo de gobierno. Realizan sendos tratados sobre la obra del Estagirita Pedro Martínez de Osma - que escribe un comentario sobre su Ética, publicado en 1460 - y Fernando de Roa, que lo hace acerca de la Politica en $1506^{171}$. Martínez de Osma fue sometido entre 1478 y 1479 a un proceso inquisitorial en que el juez, el dominico Juan de Epila, ordenó quemar todos los ejemplares de su texto De confessione, obra ésta de corte pre-erasmista, corriente presente en la Universidad de Salamanca, y que, como decíamos en la introducción, permeaba en su profesores y estudiantes —a modo de afinidad electiva - con los ideales republicanos y organicistas, así como con la circunstancia conversa. - También hay que resaltar a Juan de Segovia, que siguió posiciones conciliaristas y las imbricó con el desarrollo del constitucionalismo y el paulinismo en Castilla.

En la transmisión de la Historia de las ideas, la importancia de la Universidad de Salamanca en el XV ha quedado difuminada, más bien algo eclipsada, por la conocida como Escuela de Salamanca (o Segunda Escolástica) del siguiente siglo. Al respecto, opina García Añoveros en su prólogo al mencionado trabajo de Pena ${ }^{172}$ :

Pero la confusión es aún mayor cuando nos encontramos con autores o profesores que no han tenido reparo alguno en identificar la Escuela de Salamanca con la escuela del pensamiento teológico y jurídico del maestro Francisco de Vitoria. Me parece un abuso y un error, pues, aparte de contribuir a marginar otras importantes corrientes de pensamiento que se dieron en la Universidad, la convierten en monopolio de pensamiento doctrinal

En efecto, no habría de pasarse por alto la impronta de la academia salmantina en los años previos $^{173}$. Quizá este olvido no es casual, pues, como opinan Francisco Castilla o José Luis Villacañas, entre ambos periodos — esto es, lo que llamaríamos Primera Escuela de Salamanca y la famosa Escuela de Salamanca - no habría una relación sólo de continuidad, sino también de cierta oposición, de quiebre. Quizá tras esta segmentación se escondiera una contienda

\footnotetext{
${ }^{171}$ Acerca del aristotelismo en la Univeridad de Salamanca, pueden verse Flórez (2004), Castillo (2004), Heusch (1996) o Pagden (1975).

${ }_{172}$ Pena (2009): Prólogo, p. XIII.

${ }^{173}$ Para más información, véase Flórez (2012).
} 
intelectual; ciertamente en el panorama académico de los siglos XV y XVI castellanos podríamos señalar dos "bandos", que grosso modo ligaríamos a cada periodo de la Escuela de Salamanca: por un lado, los jerónimos, benedictinos y agustinos, más cercanos a la Primera Escuela de Salamanca y, por otro, los dominicos, con mercedarios, trinitarios y carmelitas, más vinculados a la evolución de dicha Escuela. La Primera Escuela de Salamanca aglutinó a intelectuales cercanos a una religiosidad más intimista y biblista, ergo de sesgo pre-reformista, muchos de ellos conversos y críticos con los modos de hacer de las órdenes mendicantes. Sus aulas fueron germen de este pensamiento político cristiano judeoconverso que nos está ocupando. En ellas se teorizó y cultivó un republicanismo que era materializado en las Cortes y en el corporativismo de las ciudades, y cuyo clímax - y ocaso a la vez- en Castilla fue la eclosión de las Comunidades. No sería coincidencia que tras el fracaso de la revolución comunera en la Batalla de Villalar (1521) hubiera un éxodo masivo de profesores de Salamanca a Alcalá de Henares, quedando aquélla bajo el aura dominica.

Obviamente, en cualquier caso, esta Primera Escuela de Salamanca del XV y la conocida como Escuela de Salamanca se permearon, no sería justo negar tal herencia. Tal vez sí hubo un viraje en la universidad, pues cambió sensiblemente el tipo del intelectual de prestigio previo a hechos como la consolidación de los estatutos de limpieza de sangre, la aparición de la Reforma protestante o la revuelta comunera (asociados con los conversos, el pre-erasmismo y el organicismo, y el republicanismo clásico, respectivamente). Además, la grandes cuestiones filosóficas y jurídicas que conllevó la Conquista de América obviamente reorientaron los debates. De todos modos, por ejemplo, concretamente acerca de esto último, sostenemos que sí se nutre la Escuela de Salamanca del siglo XVI del pensamiento converso conformado en la Primera Escuela de Salamanca, sobre todo en quienes veían en el bautismo de los indios una suerte de antídoto contra su reificación y maltrato, pensemos en el caso arquetípico de Bartolomé de Las Casas. Como veremos más adelante, quizá haya una filiación entre esto y la teología política de los conversos - que, asimismo, entienden instrumentalmente el bautismo como un protector contra la discriminación, la asimetría, y la exclusión, y como un catalizador universalista de unidad, igualdad, y posibilidad de participación, rasgos propios de la república.

No sería apropiado terminar esta breve sección sin señalar que la Universidad de 
Salamanca tampoco fue, ni mucho menos, la única generadora de pensamiento en el ámbito ibérico, hay que señalar también el papel de centros como la Universidad de Alcalá de Henares, o la Universidad de Coímbra ${ }^{174}$. Concretamente en Castilla también fue central el aporte de la Universidad de Alcalá de Henares, gran proyecto del Cardenal Cisneros, pues alrededor de figuras como Antonio de Nebrija (allí desde 1513) o Luis Vives, bulleron allí el iluminismo y el erasmismo. Acerca de ello, el erasmista por antonomasia, Marcel Bataillon, escribe con gran detalle y rigor en la exhaustiva obra Erasmo y España ${ }^{175}$. Justo esta obra del francés, nos lleva al siguiente apartado en esta voluntad de reconstruir las variables que conforman el contexto intelectual que catalizó lo que venimos llamando pensamiento político converso, apartado titulado «Proto-reforma, paulinismo, organicismo teológico y conciliarismo en Castilla».

\subsection{Proto-reforma, paulinismo, organicismo teológico y conciliarismo en Castilla.}

Expondremos someramente en esta sección cómo fue la religiosidad de la élite intelectual castellana del siglo XV, sobre todo del ámbito converso. El despegar de una religiosidad más intimista, demandante de un regreso directo a las fuentes bíblicas, muy crítica con una institución eclesial corrompida, y paulina en su universalismo y organicismo, fueron consustanciales al modo de vivir la fe de estos intelectuales ibéricos, por ejemplo de los integrantes de órdenes como los jerónimos, los cuales se han considerado como antecedentes del iluminismo y el erasmismo, y, por ende, de la Reforma. Parte de estos pensadores castellanos fueron miembros activos en concilios como el de Constanza o el de Basilea en los que se promovía un regreso a los textos evangélicos.

Asimismo, estos pensadores - y no sólo los conversos - fueron muy críticos con el abuso de autoridad y componente herético que entrañaban la Inquisición o los estatutos de limpieza de sangre: para ellos, una medida como dicho tribunal era lo verdaderamente herético al querer fragmentar la cohesión de la Iglesia al rechazar a los cristianos nuevos, y ello suponía la mayor aberración para la fe, pues —en palabras de Alonso de Cartagena- la peor herejía posible es que la cometen quienes: «quieren romper [la Iglesia] reviviendo diferencias anuladas

\footnotetext{
${ }^{174}$ Al respecto véase Rodríguez-San Pedro y Polo (coords.) (2006).

${ }^{175}$ Bataillon (1998).
} 
por Cristo», quienes quieren segregar al pueblo cristiano, romper su mística cohesión ${ }^{176}$. Además, esto suponía la mayor turbatio para la paz social al quebrar la unidad de los fieles .

La apuesta por una religiosidad interior y mística, más vinculada al libro y a la libre exégesis, y crítica con una institución eclesial ignorante, corrupta y mediada por el ansia de poder en la jerarquía y por el afán material (lo vemos, por ejemplo, en la ubicua venta de indulgencias, bulas y reliquias), características éstas típicamente protorreformistas, fue la propia de estos letrados. Ésta pulsión crítica de la que hablamos los llevó a un fuerte rechazo de la horquilla entre poder político (sobre todo local) y las tradicionales órdenes mendicantes, así como también a una denuncia a la potestad de estas órdenes de vigilar el culto y regularlo, determinando qué prácticas eran heréticas y qué prácticas no. Además, como hemos visto, muchos de estos letrados, eran cristianos nuevos y no parece difícil asociar este comportamiento intimista a un intelectual que ha pasado por un proceso de conversión, o el apego al libro sagrado a quien viene del judaísmo.

Ya Marcel Bataillon, una de las mayores autoridades en pensamiento erasmista, apuntó que había que rastrear en Castilla las raíces de este movimiento espiritual reformista que atravesó el albor de la Europa moderna y que cristalizó en la Reforma protestante ${ }^{177}$. Se dio una afinidad electiva entre pre-erasmismo y mundo converso. Opina José Luis Villacañas que «estas élites letradas conversas, contaban con una nueva fe que constituye nuestra proto-reforma, que no tiene nada que ver con eso que se nos ha querido vender como tal, la reforma de los franciscanos en tiempos de Cisneros (...)» ${ }^{178}$. También la estudiosa Stefania Pastore, en un interesante libro que liga espiritualidad conversa e iluminismo, explica: «Fue un tema que atravesó España, desde las primeras reflexiones de Cartagena y Oropesa hasta las teorizaciones de Talavera y las primeras meditaciones alumbradas, que se habían encontrado con el éxito europeo de Erasmo en la importante adaptación castellana del Enchiridion (...)»» ${ }^{179}$.

\footnotetext{
${ }^{176}$ Cartagena (1993): 373.

${ }^{177}$ Bataillon (1998).

${ }^{178}$ Villacañas (2017): 22.

${ }^{179}$ Pastore (2004): 225. La traducción es nuestra, el texto original es: "Era un tema che aveva attraversato la Spagna dalle prime riflessioni di Cartagena e Oropesa alle teorizzazioni di Talavera fino alle prime meditazioni alumbrade, che aveva incontrato il successo europeo di Erasmo nell'importante riadattamento castigliano dell'Enchiridion (...)”'.
} 
El paulinismo propio de esta nueva religiosidad conversa en Castilla fue perfecto caldo de cultivo para el renovado desarrollo del organicismo teológico (Iglesia como cuerpo místico de Cristo - lo vemos, por ejemplo, en Corintios 12:27 y Gálatas 3:28 - , como cuerpo — de ahí lo de «organicismo»- esencialmente cohesionado e indivisible y en el cual el Papa es cabeza dirigente y cada miembro es necesario y cumple una función ) y para su traductibilidad política en la teoría organicista del principado, como explica con detalle Ernst Kantorowicz en su famoso libro Los dos cuerpos del rey. Un estudio de teología política medieval (algo que veremos más adelante) ${ }^{180}$. Este organicismo teológico estaba basado en las doctrinas de Pablo de Tarso, de marcado carácter universalista. $\mathrm{Y}$ dicho universalismo refería tanto a una vocación de expansión y de inclusión de nuevos miembros, como a la idea de que ninguno de éstos había de ser rechazado por su origen una vez que formase parte de la Iglesia, pues al ser miembro de ésta se unía esencialmente - místicamente, en un solo cuerpo- con el resto de los miembros de la institución, independientemente del origen este nuevo feligrés. Como expone Pablo en Gálatas (3:28): «No hay judío o griego, no hay siervo o libre, no hay varón o hembra, porque todos sois uno en Cristo». Afirma también el afamado hispanista Albert Sicroff que «En España se le dio al paulinismo precisamente el sentido universalista que había defendido el apóstol» ${ }^{181}$.

Un organicismo teológico que, por otro lado, ya se había desarrollado ampliamente desde la Baja Edad Media, cuando la Iglesia ya era entendida como una suerte de república cristiana universal, liderada por el Papa y defendida su unidad por los reyes. Esta analogía organicista se declaró, de hecho, dogma de fe a principios del siglo XIV y está también ya presente, por ejemplo, en el Defensor Pacis (1324) en Marsilio de Padua, que vincula el organicismo con la civitas y promueve una teleología de la paz, además de plantear la idea de Iglesia unida en un cuerpo y adelantar ideas conciliaristas. Dicha metáfora orgánica en su dimensión mística, será también desarrollada por Jean Gerson y su De vita spirituali animae (1402), texto, asimismo, de gran influencia en la configuración de la política desde una perspectiva teologal. Después, con el pre-erasmismo y con el erasmismo, el calado de esta idea seguirá haciéndose más profundo.

\footnotetext{
${ }^{180}$ Kantorowicz (1985).

${ }^{181}$ Sicroff (1982): 656.
} 
En la teología política propia del pensamiento político converso castellano este organicismo teológico es un motivo recurrente, encontrando perfecto acomodo en obras como el Defensorium unitatis christianae (1449) de Alonso de Cartagena o el Lumen ad revelationem gentium (1465) de Alonso de Oropesa, textos sobre los que volveremos en el Capítulo 4 y sobre los que destacaremos — apoyados por estudiosos como Francisco Castilla o Albert Sicroffcómo los conversos Cartagena y Oropesa emplean la idea de cuerpo místico como argumento para promover necesaria unidad y cohesión de la república/comunidad cristiana, y por ende, para promover políticas de inclusión y la posibilidad de participación en éste, y, por tanto, en la res publica /comunidad política ${ }^{182}$. Explica Francisco Castilla que la idea de cuerpo místico constituye un vínculo de sociabilidad política ${ }^{183}$. Por su parte, el profesor José Manuel Nieto Soria realiza un sugerente análisis en el que resalta que la vertiente transpersonalizadora del organicismo tiene una clara ligazón con la idea republicana de conformación de comunidad política, la cual influyó en las sublevaciones que se dieron en Castilla con el objetivo de delimitar el poder real ${ }^{184}$.

Los conversos recuperan del organicismo paulino su vocación universalista y la emplean como argumento contra la problemática de exclusión y segregación que, por su origen judío, están padeciendo. Sin embargo, finalmente, tanto la forma de entender la fe que promovían estos conversos, como su vocación de reformismo religioso, y el proyecto político resultante caracterizado por ser inclusivo y participativo, y con Alonso de Cartagena como figura emblemática - quedó anulado al imponerse los criterios de segregación por origen promovidos por los estatutos de limpieza de sangre.

Fue recurrente en el siglo XV castellano la imagen de la metáfora organicista para justificar planteamientos de necesaria igualdad y de cohesión, esto es, con un sentido corporativo. Tal y como explica Villacañas ${ }^{185}$ :

Como es sabido, el principio de la corporación comenzó de nuevo su larga historia tras la activación por parte del papado del derecho romano, pero pronto el descubrimiento de los

\footnotetext{
${ }^{182}$ Castilla (2010) (2011) Sicroff (1982).

${ }^{183}$ Castilla (2011): 96.

${ }^{184}$ Nieto Soria (1998): 185, nota 93.

${ }^{185}$ Villacañas (2017): 4-5.
} 
textos del Código de Justiniano permitió que el pensamiento de la corporación se desplegase por todo el ámbito de la vida social. Por supuesto que el pensamiento cristiano desplegó otro concepto que no era conocido por el derecho romano y que tendió a ofrecer una base subjetiva nueva a la corporación. Me refiero a la noción del cuerpo místico (...) El calificativo mysticum aquí es el relevante y hace referencia a Pablo, e implica un vínculo ajeno a la ley, únicamente subjetivo, determinado por la charis, por el charisma, por el pnêuma de Cristo (...) Donde este pensamiento corporativo se desplegó con fuerza en la realidad social, un cierto espíritu debía echar raíces. (...) Ese espíritu fue siempre fortalecido por las dimensiones de la communio cristiana (...) Su dimensión de confraternidad participativa, [estaba] fundada en la eucaristía.

Las ideas corporativistas con su subsiguiente sentimiento de comunidad, no debían de resultar ajenas para los conversos, pues su situación les llevaba a no tener más remedio que conformar comunidad como resistencia a su discriminación, habían de constituir una comunidad, aunque fuera por su condición de exclusión, de otredad.

Nos interesa señalar cómo un mismo tópico, la metáfora organicista, es tomado por la teología y por la política, siendo al final un agente de ensamble de ambas, de recíproca influencia. Políticamente, para explicar la teoría organicista del principado y el corporativismo, teológicamente, para argumentar la necesidad de unión e inclusión dentro del orbe cristiano, para tornar un hecho su universalidad. Estas posturas fueron defendidas por quienes configuraban una espiritualidad renovada $-\mathrm{y}$, sin ellos quererlo, susceptible de ser vista como heterodoxa- esto es, conversos, iluminados y pre-erasmistas (compartiendo muchos de estos pensadores estas tres categorías).

No puede dejar de señalarse la vitalidad que en la retroalimentación de ideas religiosas y conciliaristas, entre la Castilla del siglo XV y el resto de reinos europeos, insuflaron los concilios. Por ejemplo, Alonso de Cartagena, autor que nos ocupa, acudió varias veces al Concilio de Basilea, donde pudo intercambiar saberes con humanistas del Quattrocento. También acudieron por parte de Castilla: Juan de Torquemada, Juan Alfonso López de Segovia, Rodrigo Sánchez de Arévalo, y Alfonso Fernández de Madrigal ('el Tostado'), y todos defendieron posturas conciliaristas (esto es, aquéllas que promovían una estructura más participativa dentro de la Iglesia y poner límites a la autoridad papal, o sea, la superioridad del 
concilio sobre el Papa). Hans Baron subraya la importancia de los concilios, pese al fracaso final de las posturas conciliaristas. Así lo expresa el estudioso germano ${ }^{186}$ :

Muchas de las aspiraciones medievales alcanzaron su punto crucial cuando los concilios eclesiásticos de Constanza (1414-1418) y de Basilea (1431-1449) lograron poner fin al cisma que dividió la unidad de la Iglesia; sin embargo, no lograron satisfacer las esperanzas largamente sostenidas de una reforma religiosa y la moderación de la estructura estrictamente monárquica de la iglesia (...) los dirigentes del partido de la Reforma fueron las inteligencias más notables de aquellos grandes centros de enseñanza escolástica que, anteriormente, constituyeron la fuente de avanzadas filosofías políticas, y cuyos autores, de manera incesante, habían investigado y adaptado a las condiciones cambiantes las cuestiones fundamentales de la relación Iglesia-Estado, así como las obligaciones mutuas entre los dirigentes y el pueblo. La fuerza intelectual de la filosofía escolástica en todo este campo del pensamiento fue minada cuando las consecuencias de los concilios eclesiásticos dieron fin a todos los intentos de reforma constitucional dentro de la Iglesia y convirtieron casi en absoluto el poder del Papa.

Además, los concilios fueron importantes también para el ámbito de la política interior castellana, pues, mediante los asistentes a los concilios, ésta se permeaba de posturas constitucionalistas surgidas de los debates que se generaban en torno al poder papal, esto es, en torno a la acumulación de poder personalista sin un límite externo ${ }^{187}$. Se articulaban las teorías de la ciudad con las del episcopado. Como expone Nieto Soria: «En el trascurso del siglo xv los príncipes cristianos y sus juristas, algunos de ellos con experiencia en la administración pontificia, tal como sucedía en el caso castellano, piénsese en un Alonso de Cartagena, seguirán con gran atención el debate entre las interpretaciones limitadoras y las absolutizadoras que se vayan desarrollando en el entorno pontificio» ${ }^{188}$. Como resultado de estas últimas, a la larga, se irá construyendo una cierta suerte de «pontificialismo real», de acuerdo a lo explicado por Kantorowicz $^{189}$.

\footnotetext{
${ }^{186}$ Baron (1993): 250-251.

${ }^{187}$ Para más información al respecto véase Utrera (2005) Alberigo (2004), Rivera (2012).

${ }^{188}$ Nieto (1998): 167.

${ }^{189}$ Kantorowicz (1985).
} 


\subsection{Acerca de la noción de monarquía.}

Iremos analizando en este punto la concepción de la monarquía existente en el pensamiento político converso castellano del $\mathrm{XV}$, teniendo en cuenta las aristas que consideramos más relevantes al determinar dicha concepción:

1) Primeramente la cuestión del origen y los límites de la autoridad - de acuerdo al iusnaturalismo, a los valores republicanos y al modelo de gobierno mixto-.

2) Después las teorías organicistas del principado.

3) Asimismo, la influencia de la variable profética propia de los intelectuales conversos en la concepción de monarquía.

4) Y, finalmente, considerando el enfoque tradicional de la idea de monarquía hispánica, transido de la noción de rey como vicario de Cristo, de patriotismo y de la idea mítica de monarquía gótica.

Los letrados de Castilla no sólo trabajaron como hombres de Estado en labores administrativas y de consejo, sino que contribuyeron desde sus escritos a crear el marco normativo y arquetípico sobre lo que la monarquía castellana significaba, y a fortalecer su pertinencia y legitimidad. Así lo explica G. Sabine: «La mayor parte de los defensores del monarca eran juristas, hombres preparados y empleados profesionalmente en los tribunales reales o el consejo real, dispuestos a utilizar los recursos del derecho romano en ayuda de la monarquía hereditaria ${ }^{190}$. En ocasiones se ha juzgado con demasiada precipitación a pensadores castellanos, como aquél que es nuestro objeto de estudio, Alonso de Cartagena, asumiendo que su exaltación del monarca era parte de un aparato de legitimación de un incipiente absolutismo y de un uso ilimitado del poder, lo cual estimamos incorrecto. Como veremos en seguida, estos intelectuales ni tenían un enfoque teocrático del rey ni promovían la falta de control en su ejercicio de la autoridad, sino más bien al contrario (un control vía el iusnaturalismo, el constitucionalismo, el parlamentarismo y el organicismo). Defendían la monarquía -y es cierto que la concepción de la figura del rey estaba atravesada de la idea de liderazgo, de vicariato de Cristo, de profetismo y de goticismo - pero se defendía la monarquía implementada bajo la

\footnotetext{
${ }^{190}$ Sabine (1982): 201.
} 
forma de gobierno mixto, esto es, con instituciones y control jurídico que actuasen como herramientas contra la arbitrariedad y el abuso en ejercicio de la autoridad por parte del monarca y que garantizasen la participación de las distintas instituciones representantes de los ciudadanos. Como vimos en el capítulo primero - y a diferencia del enfoque de Hans Baron o P.G.A. Pocock y sus seguidores - son perfectamente compatibles la defensa de la institución monárquica y la defensa de valores republicanos, y lo que materializa esta compatibilidad es el modelo de gobierno mixto.

Tal y como apuntamos en el capítulo previo, hay que hacer notar del caso castellano algo que lo diferencia por ejemplo del florentino - el que la gran mayoría de los pensadores conversos que nos ocupan apoyaban a la institución monárquica (salvo alguna excepción como Alonso de Madrigal). Ésta como tal no se cuestionó, lo cual no quiere decir que, en sintonía con los valores republicanos, no hubiera una vocación de observancia y control institucional al ejercicio de autoridad real, y que se promoviesen instituciones propias del modelo de gobierno mixto. Como afirma Pablo L. Alonso Baelo en referencia a la revolución comunera de 1521 (revuelta que cristaliza el pensamiento político de la élite conversa), las emergentes élites intelectuales y sociales asumieron «(...) una crítica de la legitimidad del poder político y una reconstitución del poder político fundado en esa crítica» ${ }^{191}$. Una cosa es que esto aconteciese y otra distinta que se dudara de la pertinencia, justificación y función social de la monarquía. En Castilla fue indudable la adhesión a la monarquía, pero las ideas republicanas vinculadas al origen del poder, la participación, la sociabilidad, la libertad como no dependencia, la virtud y el bien común se trataron de articular con la idea de un monarca virtuoso, justo y sabio, y el cual había de estar en las antípodas de la tiranía. Otra característica que se argüirá para defender la figura del monarca frente a un gobierno a cargo de más agentes, es que en éste último habría diversidad de intereses y disensión, mientras que en la monarquía hay unidad de criterio. Un criterio, el del rey, que no vela por su propio interés, sino que se rige en pro bien común. Además, el rey sintonizará en un beneficio recíproco la gobernanza de los distintos territorios bajo su mandato y se presentará como defensor pacis que referirá la paz a un orden natural preexistente. Asimismo, como veremos en seguida, otros argumentos a favor de la institución monárquica en Castilla serán la asunción del monarca como vicario de Cristo, su papel como

${ }^{191}$ Alonso Baelo (2007): 459, 460. 
cabeza rectora bajo un prisma organicista, su dimensión profética y su rol como garante de la idea mítica goticista de monarquía hispánica.

En lo referente a la cuestión del origen de la autoridad, este apoyo a la monarquía en Castilla convive y se engarza con el enfoque propio del Derecho Natural: la autoridad, o potestas, es transferida por Dios al pueblo, a la comunidad política, y posteriormente es la comunidad política la que se la transfiere al monarca, por ello no hay una concepción teocrática en la que Dios le transfiere la autoridad al rey, que puede usarla de un modo indiscriminado. Este enfoque según el cual la autoridad tiene un origen popular fue reproducido por la escolástica medieval y en el caso castellano quedará ya consolidado y teorizado por los autores de la Segunda Escolástica. Es cierto que se partía de que esta suerte de "pacto" por el cual el pueblo transfirió en el pasado al monarca la autoridad no era necesario renovarlo cada vez que un nuevo monarca llegaba al poder, pero eso no implica que el origen de la autoridad no sea popular.

Todavía en el siglo XV, en los reinados de Juan II, Enrique IV y los Reyes Católicos, no habrá tratados iusnaturalistas tan elaborados ni de raigambre contractualista sobre el origen de la autoridad real, la transferencia de la potestas, o dominio, y la legitimidad de la monarquía como los que en las décadas posteriores realizaría la Segunda Escolástica, con figuras como, entre otras, Francisco de Vitoria (con su Relectio de potestate civil de 1529, por ejemplo), Domingo de Soto (con su De dominio de 1534, por ejemplo), Juan de Mariana (con su De Rege et regis institutione de 1599, por ejemplo), o Francisco Suárez (con su Principatus politicus o la soberanía popular, Libro III del Defensio Fidei de 1613, por ejemplo), todos ellos con un impecable apego a la idea de legitimación dentro de la legalidad ${ }^{192}$. Sin embargo, sí se perfilan en el cuatrocientos castellano teorías que abogan por la idea del origen popular de la autoridad. Así, en algunos textos del autor que nos ocupa, Alonso de Cartagena, la relación entre el monarca y la población no se presenta sólo basada en la subordinación de ésta a aquél, sino que se muestra la idea de que el pueblo transfiere la potestas, de la que es depositaria, al rey. Lo vemos por ejemplo en textos derivados de sus intervenciones en el Concilio de Basilea. En De preeminentia, presentado en 1434, afirma: «E es de saber que aunque el poderío real sea dado

\footnotetext{
${ }^{192}$ Vitoria, de (2008), Soto, de (1995), Mariana, de (1945), Suárez (1965).
} 
por Dios, pero los regnos començaron por ministerio e acto del pueblo» ${ }^{193}$. En las Allegationes, de 1437, asevera: «El poder común es trasladado del pueblo al príncipe» ${ }^{194}$. De todos modos, estas ideas ya las apuntaba el Digesto, fuente constante en Cartagena.

No obstante, como decíamos arriba, no por ello la institución monárquica se cuestiona ni deja de estar vista de un modo providencialista: el rey será vicario de Cristo. Conviene aclarar aquí, que providencialista no quiere decir necesariamente teocrática y absolutista sin controles externos, como, por ejemplo, pretenderá años más tarde el rey Jacobo I de Inglaterra, paradigma del afán por anular las teorías populistas. Como expone Javier López Alós, el providencialismo no implica directamente ni teocracia ni gobierno absoluto (según este estudioso, en el mundo católico lo segundo se da en la siglo XVII a partir de Jacques-Bénigne Bossuet). De hecho, este estudioso advierte de que la idea de teocracia es, de hecho, incompatible con el catolicismo, por más que, equivocadamente, se asocien. Explica que en ningún caso se puede hablar de teocracia en un caso como el castellano, pues el poder no es ejercido por el cuerpo sacerdotal, el monarca reina por ser jefe de la Iglesia (y no al revés, como en Inglaterra), y sí hay distinción entre ley civil y religiosa. Apunta, asimismo, que es un error que se repite constantemente el de relacionar absolutismo y teocracia, cuando en realidad responden a lógicas prácticamente opuestas ${ }^{195}$.

Acerca de esta cuestión es revelador el apunte que hace Antonio Rivera en un texto sobre la noción de la potentia Dei (o sea, la omnipotencia divina) y su vinculación con la apología de la monarquía en los Estados modernos absolutistas. Aclara este estudioso que la teoría de que hay una transferencia de potentia Dei al soberano temporal es algo propio de la defensa y promoción de Estados-nación ya en los siglos XVI y XVII, mientras que no es lo propio de la teología política escolástica en la que se enmarca el pensamiento político converso del XV castellano al que nos estamos refiriendo. Con ayuda de los aportes de Ernst H. Kantorowicz las contrapone ${ }^{196}$. Cito a Antonio Rivera ${ }^{197}$ :

\footnotetext{
${ }^{193}$ Penna (1959): 218a.

${ }^{194}$ González Rolán (1994): 130.

${ }^{195}$ Tomamos esta reflexión de un comentario escrito de García Alós a la lectura de un borrador este capítulo. En el mismo, dicho estudioso indica también que para información complementaria al respecto, puede verse el trabajo $E l$ sentido de la Historia. Implicaciones teológicas del sentido de la Filosofía de la Historia de Karl Löwith (1956)

${ }^{196}$ Kantorowicz (1985).

${ }^{197}$ Rivera (2001): 171.
} 
Se desarrolla al mismo tiempo una teología política de corte medieval, la que mediante la distinctio entre potentia absoluta y potentia ordinata modera o limita el poder divino y temporal, y una teología política moderna o absolutista. La primera, la medieval, no debe ser confundida con la de Ernst H. Kantorowicz, quien simplemente se refiere al hecho de que el pensamiento político de la corona y del rex está influido por las reflexiones de los canonistas en torno a la inmortalidad de la persona mystica; pero, en ningún momento, ha juzgado que la clave de la teología política se halla en la transferencia de la potentia Dei al soberano temporal. La moderna o absolutista coincide con la de Hobbes, el cual partiendo de un Dios parecido al calvinista, ve en aquella distinción una mera sutileza escolástica, pues los poderes divino y estatal son siempre absolutos, y, en consecuencia, no tiene sentido hablar de potentia ordenada como si fuera algo distinto de la absoluta.

En relación a la idea de la necesidad de poner límites a la autoridad real, este modelo de monarquía — cuyo diseño los propios pensadores conversos castellanos estaban contribuyendo a implementar - partía de la conveniencia de limitar la autoridad del rey y evitar su potencial arbitrariedad. Como explica, por ejemplo, Francisco Quijano, para ello existían diversos mecanismos de control (además del consuetudinario respeto a los usos y costumbres tradicionales), mecanismos acordes con la noción republicana de participación y con el espíritu constitucionalista medieval, así la existencia de fueros y pactos, de leyes positivas y de instituciones representativas (las Cortes castellanas) ${ }^{198}$. Es muy destacable la tradición "parlamentarista" de Cortes en Castilla y sobre ella y el modelo de gobierno mixto nos detendremos en el siguiente apartado, de ahí que ahora no nos extendamos más en este aspecto.

La monarquía castellana, sobre todo en su desarrollo como monarquía hispánica en el siglo XVI, ha tendido a mostrarse como paradigma del absolutismo, aunque desde hace décadas se intenta deconstruir este relato (en mucho fruto de la Leyenda Negra, como apuntan los profesores Francisco Castilla y María José Villaverde) ${ }^{199}$. Para ello se ha trabajado bastante en torno a la historia y el funcionamiento de las Cortes - así como de otros mecanismos de "autogobierno", por ejemplo dentro de municipios, órdenes o grupos políticos corporativos-y se ha demostrado que el monarca constantemente había de llegar a acuerdos con las ciudades y otras corporaciones de los distintos reinos (entidades que esgrimían posturas constitucionalistas), así que de facto, en muchos aspectos su autoridad quedaba limitaba y estaba constantemente sujeta a negociación. Una cosa es que el discurso oficial pudiera mostrar pretensiones

\footnotetext{
${ }^{198}$ Quijano (2017): 26.

${ }^{199}$ Castilla y Villaverde (2016).
} 
absolutistas y otra la realidad de la gobernanza.

De igual modo, Henry Kamen caracteriza el absolutismo español en los comienzos de la Modernidad, y opina que éste ha se ha sobredimensionado, pues no fue tal absolutismo, ni de facto en la gobernanza, ni normativamente, ya que los juristas legislaron para controlarlo; afirma críticamente este experto ${ }^{200}$ :

Aquí el problema central es que los historiadores en España nunca han estudiado el concepto de absolutismo, y han tendido a utilizarlo como un adjetivo para describir casi cualquier tipo de autoridad política. En la práctica, «absolutus», tal como se define desde la época medieval, simplemente significaba poder que estaba exento de controles; y sabemos que el poder de Fernando [el Católico] distaba mucho de ser incontrolado. No sólo fue su poder limitado por la ley, por tradición, y por las Cortes, sino que también estaba obligado a compartir casi todas sus funciones con su esposa.

Estima, Kamen asimismo, que el rey no aspiraba a plenos poderes absolutos, aunque sí reconoce la concepción mesiánica del monarca (apunta, al respecto, el objetivo atávico de tomar Jerusalén consustancial a la monarquía hispánica), y opina también que el Santo Ofício no desempeñó un papel tan determinante para la formación del Estado moderno español ${ }^{201}$. Según él, el mejor - y el único - estudio serio sobre el absolutismo real en España es el de I. A. A. Thompson, en el que dicho estudioso asevera que los juristas castellanos «rechazaban el concepto de poder absoluto como ilegítimo y execrable» ${ }^{202}$. Ciertamente, pese que durante el siglo XV hubiera un claro apoyo al rey, los letrados que ensalzaban la monarquía no jaleaban la arbitrariedad del poder del monarca y siempre promovieron el control jurídico y a través de la Cortes del ejercicio de poder real.

Recordemos que la idea de reino medieval no estaba contrapuesta en absoluto con el Derecho Romano y su corporativismo inherente, sino al contrario. Y, a su vez, donde encontramos derecho corporativo medieval es lógico que germine republicanismo. Éste es otro argumento, de acuerdo a la lógica medieval, para, como venimos sosteniendo, rechazar la oposición sin más entre reino y republicanismo. Esto es, para explicar que es un anacronismo

\footnotetext{
${ }^{200}$ Kamen (2014): 20-21.

201 Kamen (2014).

202 Thompson (1981). Tomo la cita de Kamen (2014): 23, nota 25.
} 
contraponer a priori monarquía y república, tal y como vimos en el Capítulo 1. Con todo esto lo que queremos mostrar es el modelo mixto que se perfiló en Castilla, que promovía una monarquía, pero controlada en su ejercicio de la autoridad por una serie de instituciones y cuerpos políticos con los que había que pactar, y por una serie de leyes que impedían el uso tiránico de la potestas real, en línea con los valores constitucionalistas. Es decir, la forma en que se adaptaron las ideas republicanas al siglo XV castellano no dudaba de la pertinencia de la institución monárquica, es más, la incorporaba. Y esto era compatible, y además se enriquecía, con la teoría organicista del principado y con las ideas providencialistas de un monarca vicario de Cristo que defiende la cristiandad, así como con la visión profética del rey heredada por estos pensadores conversos del judaísmo, pasemos a continuación ver estas características.

Es sabido que la metáfora organicista tiene una larguísima tradición, tanto en la filosofía política como en la teología: ya está en la República de Platón o en la Política aristotélica, pero es en la Edad Media donde esta analogía reaparece con más fuerza. Desde la perspectiva meramente civil se retoma con fuerza la vertiente aristotélica, y desde la teología política — que es la que más nos atañe ahora para analizar el caso castellana y su concepción de monarquía providencialista - se recupera la tradición paulina basada en la idea de Iglesia como cuerpo místico de Cristo, como república cristiana indivisible, liderada por el Papa y pacificada por los reyes. Recordemos que esta teoría asume la sociedad como un cuerpo: la metáfora consiste en identificarla con el cuerpo humano y asociar cada miembro u órgano a cada individuo, o a cada grupo social. Este cuerpo es indivisible, está intrínsecamente unido. Y cada miembro cumple una determinada función, que, además, es necesaria para el resto, en una suerte de simbiosis. El miembro de mayor importancia - la cabeza (el corazón en otros casos) - sería el monarca, y, pese a que sus funciones son más relevantes y ha de dirigir a las de otras partes, las funciones de cada miembro son vitales (aunque su función parezca en principio más modesta). En su famoso libro Los dos cuerpos del rey. Un estudio de teología política medieval, Ernst Kantorowicz explica que la noción de corpus republicae mysticum podía significar tanto toda la comunidad cristiana, como cualquier corporación que difiera del individuo ${ }^{203}$. $^{20}$

${ }^{203}$ Kantorowicz (1985). 
Nos parece de mucha utilidad la revisión que hacen autores como Cappeli o ValeraPortas de binomio organicismo y monarquía para el caso italiano, de hecho ellos entienden el organicismo como un elemento inherente a lo que Cappelli llama humanismo político, refiriéndose a la presencia de valores republicanos en la teoría política del Quattrocento ${ }^{204}$. Sería de interés aplicar esta lectura suya del organicismo al caso castellano, sobre todo en lo tocante a la unión rey-pueblo, que va más allá de la representatividad.

Como intentamos sostener, el ideal de monarquía del pensamiento político converso castellano del XV se nutrió (y aportó también) de la idea de príncipe renacentista. Esta noción de princeps, en oposición al monarca absoluto que llegaría, no es algo separado de su pueblo: para el modelo hispánico (que, reiteramos, no da explicación teocrática de la potestas: sí providencialista, pero no teocrática), el pueblo entrega la potestas al monarca, el cual, magnánimamente, por su catadura moral virtuosa, decidirá gobernar con justicia (además de por miedo a que se lo considere tirano y entonces sea legítimo revocarlo), pero, de algún modo, esta entrega de la potestas es un poco "endógena”, ya que príncipe y pueblo están unidos. El príncipe está ligado con el pueblo, forman una unión indivisible, una suerte de sistema -la metáfora organicista entendida en toda su profundidad así lo implica - por ello, en la cesión de potestas del pueblo al monarca, el pueblo no hace una entrega del dominio a algo totalmente exógeno de sí. El monarca es cabeza del resto del cuerpo-pueblo con el que se une en una suerte de relación de 'asimilación sinecdótica', es decir, se da una relación de sinécdoque en la medida en que hay una identificación de la parte por el todo. Pero sería una asimilación no restrictiva para el rey pues el rey tiene virtudes y cometidos que el pueblo no- y no simétrica - pues el rey es superior en atributos-. Esto es relevante porque implica que necesariamente tiene que haber príncipe si hay pueblo y viceversa. Como vemos, ésta no es una explicación del origen de la autoridad en absoluto teocéntrica, sí mesiánica tal vez, pero compatible con la distinción entre gobierno temporal o civil y el gobierno de lo espiritual, distinción, por otro lado, perfectamente habitual y lógica de acuerdo con la doctrina católica del poder; así, como explica Kantorowicz, la teoría medieval de la doble potestad del rey ${ }^{205}$.

\footnotetext{
${ }^{204}$ Cappelli (2006, 2009, 2011), Varela (2016).

${ }^{205}$ Kantorowicz (1985).
} 
Al respecto indica el estudioso Juan Valera-Portas que este enfoque de la monarquía apela a la generación de consenso, de concordia (él se refiriere más concretamente al caso italiano, pero son sus apreciaciones, creemos, extrapolables —eso sí, con cautela, siendo conscientes y salvando las distancias - a Castilla). En torno al príncipe se creará una nueva mayoría social, su liderazgo no es "totalitario", no es un tirano, sino que su figura armoniza, pues es el alma del cuerpo social. Crea una suerte de sinergia y de adhesión, conforma pueblo y conforma nación. Del modo del que acontece esta unión implica que el príncipe no es un líder que representa, no hay esa distancia, está inherentemente unido al pueblo en lo que este estudioso denomina una sinécdoque confusiva. El monarca condensa la ley y las virtudes públicas y privadas, las cuales se trasladan al pueblo que las hará suyas, es como si el princeps fuera el alma de esa unión, el motor de la misma. Y estas virtudes regias son además una forma de cohesión del pueblo ${ }^{206}$.

En la misma línea está el profesor Guido Cappelli, que estima que la legitimidad se consolida en torno a la propia figura del príncipe, del líder: él coagula la legitimación de su poder y para mantener ésta habrá de gobernar bien, es decir, mantener estas virtudes sin las cuales devendría un tirano. El rey tendrá una relación de amor (en sentido político y como vínculo de orden moral) con sus súbditos, y esto, además de su talante virtuoso, será también acicate para el buen gobierno en pro del bien común y garante de que no obrará en su propio beneficio. Diego de Valera, en su Doctrinal de príncipes de 1474, deja clara la orientación política de esta noción de amor del monarca a su pueblo por el que velará, ideas éstas propias del organicismo al que remitimos: «Ca el rey con su reyno es como un cuerpo humano, cuya cabeça es él; e asý como todos los mienbros s'esfuerçan a deffender e anparar la cabeça, asý ella deve trabajar de regir e governar e ayudar los miembros»» ${ }^{207}$. Además, en esta cita podemos observar el principio de reciprocidad — de mutua obligación - entre el rey y sus súbditos, mutuamente se defienden y amparan, dice Valera. Una postura afín a Valera tendrán, por ejemplo, Alonso de Oropesa, en su Lumen ad revelationem Gentium, escrito en 1465, y el propio Cartagena en su Defernsorium unitatis christianae (sobre el que versará el capítulo 4 de este trabajo), donde

\footnotetext{
${ }^{206}$ Estas afirmaciones de los profesores Varela-Portas y Cappelli están basadas en notas tomadas por mí de su ponencia: "El Humanismo, ¿es un populismo?”, pronunciada el 22 de septiembre de 2016 en el congreso Populismo vs. Republicanismo: genealogía, historia, crítica, celebrado en la Facultas de Filosofía de la Universidad Complutense de Madrid entre el 20 y el 23 de septiembre de 2016.

${ }^{207}$ Valera (1982): 33.
} 
realiza afirmaciones como las siguientes: "Así nosotros siendo muchos somos un solo cuerpo en Cristo, pero cada miembro está al servicio de los otros miembros»o «Y así resulta que el cuerpo místico compuesto de esta forma y materia se llama ciudad» ${ }^{208}$.

Cappelli quiere hacer notar la importancia de la base popular en esta unión entre el pueblo y su rey, y reaccionar a la crítica que, según él, la academia anglosajona liberal ha hecho a la figura del princeps defendida por los pensadores del siglo XV. Critica que autores como Baron o Pocock, al caracterizar la figura del monarca como autoritaria, no están comprendiendo plenamente esta cuestión de la metáfora organicista y esta unión príncipe-pueblo como sinergia virtuosa. Y que, por ello, están defendiendo, erróneamente, un republicanismo en el que no cabe la figura del rey, postura ésta de Cappelli con la que concordamos. Opina, asimismo, que los seguidores de la tesis baroniana del humanismo cívico, incurren en un anacronismo al asumir que en siglo XV se pretendiese o hubiera una especie de república democrática, y que se equivocan al pensar que la existencia de un rey, implicaba necesariamente que éste podía ser autoritario sin control alguno. Lo que sucede, continuando con el estudioso italiano, es que los mecanismos de control podían ser también otros más allá de la proclamación de una ciudad/república parlamentaria sin monarca. Otro elemento de limitación del poder que operaba, y no sólo simbólicamente, era la cuestión de la ejemplaridad del monarca (rex como exemplar mundi, modelo del mundo): el príncipe pasaba constantemente por el examen de las élites corporativas y de la población, siempre con el riesgo de ser calificado como tirano (lo que justificaría que lo depusiesen). El monarca era sometido a expectare. Y esta expectare era una herramienta real de control. Existían lógicas reguladoras del uso de la autoridad del rey además de las de corte constitucionalista y parlamentarista (que promovían un modelo de gobierno mixto), nos referimos lógicas de limitación de la autoridad de orden moral, esto es, de catadura más simbólica (aunque perfectamente compatibles con las anteriores). Estas lógicas de orden moral que limitan la potestas del rey y evitan el abuso en su ejercicio de la autoridad, son sobre todo la idea de la virtud intrínseca al monarca (que le hará llevar a cabo un buen gobierno en aras del bien común) y la idea del tirano como corrupción de este ideal de rey virtuoso.

${ }^{208}$ Cartagena (1993): 210 y 392, respectivamente. 
Sobre el tópico del rey virtuoso hay que recordar que esta idea de virtud coincidía con el enfoque cristiano a rectitud moral y búsqueda del Bien, pues la filosofía de la acción esperada de un gobernante si carecía de fundamentos éticos sería tan sólo acción instrumentalizada. Durante la Edad Media se había consolidado la idea cristiana de virtud, también en el ámbito político (noción que, obviamente, había tomado mucho del aristotelismo cristiano), por ello los espejos de príncipes requerían al rey ser epítome de un comportamiento virtuoso. En palabras de José Abad: «(...) las virtudes principescas serían una amalgama de la virtù elogiada por los clásicos (la honestidad, la magnanimidad) bien combinada con la idea de entereza refrendada por la religión cristiana». Este mismo autor remite al converso Diego de Valera como ejemplo paradigmático en la Castilla del XV de esta idea, a su Breviloquio de virtudes y su Doctrinal de príncipes (obra esta última de 1476 y la cual se ha visto por algunos como antecesora e inspiradora de El Príncipe de Nicolás Maquiavelo, aunque con la diferencia, de que, según Abad, Maquiavelo rompió con la tradición moral al desplazar el concepto de «virtù» del ámbito moral a la órbita de la utilidad política) ${ }^{209}$.

Conviene aclarar de todos modos, con Friederich Meinecke, que la virtud no es exclusiva del monarca, también se da y ha de regir a la comunidad política, por tanto, puede leerse esta idea de virtud como «un puente interno entre las tendencias republicanas y monárquicas». Y continúa Meinecke refiriéndose a la virtud: «(...) ésta debería residir en una ciudadanía convenientemente sensibilizada (y reforzaría cualquier república de ser ésta la opción política) y hallarse igualmente en el líder (y esto redundaría en beneficio del principado, en caso de decantarnos por éste) ${ }^{210}$.

En cuanto a la idea de tiranía es muy interesante el cómo fue una constante en Castilla al reflexionar sobre la monarquía, una larga tradición que llega a su clímax teórico durante el siglo XVI con la Segunda Escolástica, cuyos pensadores elaborarán toda una teoría del tiranicidio, entendida esta deposición del tirano como un legítimo derecho del pueblo. El rey tirano se presenta como envés del rey virtuoso y el comportamiento tiránico del gobernante es una prueba de su ilegitimidad. Si el monarca no actúa pensando en el bien común sino en el propio, si ejerce

\footnotetext{
${ }^{209}$ Abad (2008).

${ }^{210}$ Meinecke (1983): 35.
} 
arbitrariamente su poder sin respetar las leyes ni los intereses del resto, si no ha interiorizado que su mandato es una forma de servicio al pueblo, entonces actuará como un tirano y será lo correcto represaliarlo. De hecho ésta es otra forma de control popular y puesta de límites a la autoridad real. Cappelli asevera que la cuestión de la tiranía se presenta en Castilla «como un elemento básico de una teoría política que a la dimensión clásica y cristiana -'el Profeta' (David) y 'el Filósofo' (Aristóteles)- le añade un cierto perfil jurídico-político, apoyado en el De tyranno de Bartolo de Sassoferrato y el De regia potestate de Giovanni da Imola ${ }^{211}$. Y apoyado, además, añadimos, en la tradición jurídica Alfonsina castellana.

En las legitimaciones de los siglos siguientes al XV del absolutismo moderno, la retórica de la virtud en torno al rey quedaría más hueca, pues no permanecieron los mecanismos de control que se planteaban en el cuatrocientos. Posteriormente sobrevendrían, por un lado, la legitimación del absolutismo, y el lenguaje político de la Razón de Estado, y, por otro, un liberalismo no igualitario cuya representatividad no sería tan inclusiva como lo era la unión organicista. En esta unión organicista se daba una impersonalidad del líder, vía la fusión reypueblo y vía la identificación del rey con la ley (rex-lex), identificación que ya está presente en Cicerón. Leemos en De officiis: «Los que dirigen la res publica deben comportarse como si fueran la ley misma» ${ }^{212}$. Hemos de entender al rey más que como una persona como una función pública. El monarca será un mediador, un representante del cuerpo todo, y no actuará como individuo privado; de hecho su voluntad será en realidad la misma que la de toda la comunidad política a la que dirige, su voluntad coincidirá entonces con la voluntad común.

De todos modos, como apuntábamos antes, este control de la autoridad del monarca vía la expectatio de su gobierno virtuoso no era excluyente sino complementario con la limitación y contrapeso al poder regio por la vía "parlamentaria" (las Cortes en el caso de Castilla) o por la vía jurídica, y con el valor de participación de los ciudadanos en la vida cívica, todo ello enlazado con la recuperación de valores republicanos. Organicismo monárquico y pensamiento republicano se complementaban, por mucho que esta afirmación pueda chocar a primera vista.

\footnotetext{
${ }^{211}$ Cappelli (2014): 4.

${ }^{212}$ De officiis I, 89. Tomo la cita de Cappelli (2014): 8.
} 
Hay algo importante en lo que, sin embargo, nos distanciamos de autores como Cappelli y Varela-Portas dado el contexto castellano que nos ocupa (autores que se centran en Italia y a los cuales hemos seguido aquí en varios aspectos al hablar del organicismo monárquico). Como ya apuntamos al final del capítulo primero, nos distanciamos de su aseveración de que este humanismo político, como ellos lo llaman, es necesariamente inmanentista (no trascendentalista), secular (un secularismo éste de la primera modernidad que pretendía disminuir un poder papal que no ayudaba a la llegada de ese prínceps anhelado por el organicismo) y laico. Para el caso castellano parece más complicado aplicar lo de la inmanencia del monarca, pues el príncipe o líder ex novo que plantean estos estudiosos no concuerda con una idea mitificada y antigua que se tenía de la monarquía gótica y tampoco con la idea providencialista del rey vicario de Cristo, ni con la dimensión profética con que era concebida la figura del monarca en Castilla. Todo lo cual, maticemos, no quiere decir en absoluto que en la Castilla del XV que se estuviera legitimando un enfoque teocrático, no contractualista y absolutista, o que no se fuese consciente de la problemática relación entre Iglesia e imperio. Sin embargo, como hemos venido repitiendo, en Castilla se tenía una concepción escatológica de la historia y una idea providencialista del monarca dentro de ella. Para entender el sentido profundo del la monarquía en Castilla es necesario articular esta noción que hemos visto arriba del organicismo monárquico con las nociones religiosas de mesianismo y profetismo semíticas, con las de universalismo y unidad de la república cristiana paulinas, con el misticismo pre-erasmista, y con la idea mítica y fundacional de la monarquía gótica hispánica. Veamos a continuación estos rasgos específicos que son también determinantes en esta concepción de la monarquía propia del pensamiento político converso castellano del siglo XV que estamos intentando describir.

La percepción de monarquía del colectivo converso estaba atravesada del profetismo propio de su cosmovisión semítica, pues, pese a la conversión, su cosmovisión judía seguía estando presente en muchos aspectos, algo por otro lado lógico dado que era la matriz intelectual de los cristianos nuevos. Es interesante el fenómeno que se dio en Castilla: a este providencialismo propio de la tradicional visión de la monarquía gótica (que en seguida veremos) se adecuó el mesianismo inherente a la cosmovisión judía que portaban los conversos. Éstos, aunque asimilados (esto es, en mucho aculturados para demostrar cuán buenos cristianos eran tras la conversión) mantuvieron determinados aspectos del hebraísmo - a veces con 
orgullo, otras sólo por una inevitable inercia—. Y, así, reprodujeron su concepción mesiánica y profética del líder, pero la resituaron en la figura del monarca, y ya no en una espera de un mesías redentor (pues según el cristianismo ya éste había llegado con Cristo), aunque al rey también le otorgaron la función de caudillo religioso que velaba en lo temporal por la salvaguarda de la fe. Respecto a la visión de los conversos castellanos sobre la figura del monarca, es destacable lo que escribe José Manuel Nieto Soria: «Al constatar ahora el importante relieve de las obras de los conversos castellanos del siglo $\mathrm{xv}$ desde la perspectiva específica de la presentación de una imagen de la realeza, no queda más remedio que volver a plantearse la pregunta (...): ¿existió una sensibilidad distintiva y característica hacia la concepción del poder regio entre los intelectuales conversos en la Castilla del siglo xv?» ${ }^{213}$.

Dicho estudioso estima que no podemos aseverar que haya una imagen monarquía específicamente conversa, pero reconoce que, aun así, podría haber una serie de «elementos constitutivos básicos que incidieron en la elaboración de un cierto concepto de monarquía». Éstos son ${ }^{214}$ :

1) La presencia de una preocupación muy difundida por establecer elementos de reflexión intelectual sobre el nuevo sentido que parecía que iba tomando la institución monárquica. 2) El pensamiento teológico-político orgánicamente expresado a partir del siglo XIII y ampliamente difundido durante el siglo XV. 3) La incidencia de los textos bíblicos, sobre todo los veterotestamentarios. 4) Las expresiones de las tendencias autoritarias que pretende desarrollar la monarquía en su proceso de configuración de una solución estatal (...) 5) La visión histórica de una monarquía castellana a la que se suele atribuir una proyección hispánica, visión histórica elaborada a partir de los criterios propios de la construcción de los denominados «falsos», caracterizados por dar legitimidad a partir de una supuesta antigüedad, casi siempre imaginada. 6) Las propias experiencias individuales de índole política (...)

Se centra Nieto Soria en su trabajo en los casos de Fernando del Pulgar y Diego de Valera, pero menciona también a otros conversos apologetas de la monarquía en los textos de cancionero o literarios en general (así, Juan Alfonso de Baena, Íñigo de Mendoza, Juan Álvarez Gato, o Juan de Lucena, entre otros), y, finamente, habla del clan familiar de los Santa María (al que pertenece Alonso de Cartagena). Para este académico, la visión de estos conversos respecto

\footnotetext{
${ }^{213}$ Nieto Soria (1993): 232.

${ }^{214}$ Nieto Soria (1993): 246-247.
} 
al monarca no es homogénea. Expondrá que en el caso de del Pulgar estamos ante lo que podría entenderse como una percepción religiosa de la realeza y no así en el de Valera, donde la percepción es esencialmente jurídico-política. Nos interesan las palabras de Nieto sobre Fernando del Pulgar, además son aplicables también a Alonso de Cartagena y a la visión del rey que muestra en su Defensorium, y la cual abordaremos en el capítulo cuarto al analizar esta obra. Escribe Nieto Soria ${ }^{215}$ :

La «percepción religiosa» de la realeza, exhibida por Fernando del Pulgar, se asienta en la caracterización del monarca a partir de una cuádruple óptica. El monarca es un ungido de Dios, posee una inspiración divina y es un rey mesías y un rey cristianísimo (..) [Existen] planteamientos mesiánicos empleados por Fernando del Pulgar para describir lo que considera como una de las facetas esenciales de su ideal monárquico (...)un enfoque de la realeza de índole religiosa, en el que los contenidos mesiánicos, profetices y providencialistas ocupan un lugar central. Esta circunstancia ha llevado a pensar a algún autor que todo ello es una manifestación de su origen judío

José Cepeda Adán, por su parte, enuncia en la misma dirección: «En su estilo y, sobre todo, en su mesianismo aparece clara esta huella de su origen. Pulgar, cristiano nuevo, aunque de la más limpia ortodoxia, está empapado de hebraísmo en sus juicios históricos. No concibe la Historia sin una intervención decidida y final de Dios. Sus palabras tienen a veces acento bíblico y resuenan como una voz profética» ${ }^{216}$.

Otro aspecto relacionado con este profetismo de impronta judía que nos parece relevante señalar es cómo este rey/mesías funda comunidad política, esto es, funda pueblo. El monarca aglutina y lidera a una comunidad religiosa que es también una comunidad civil. Estas influencias semíticas en los conversos serán definitorias en su articulación entre teología y pensamiento republicano, rasgo que venimos defendiendo durante todo este trabajo es propio y diferenciador del pensamiento político castellano del XV, y que constataremos con el análisis de la obra principal de Alonso de Cartagena en la segunda parte de este escrito.

\footnotetext{
${ }^{215}$ Nieto Soria (1993): 234, 237.

${ }^{216}$ Tomo la referencia de Nieto (1993): 237, de la nota al pie número 30. CEPEDA ADÁN, José (1959): “El providencialismo en los cronistas de los Reyes Católicos”, en Arbor, n. ${ }^{\circ}$ XVII, págs. 179-80.
} 
Como último factor que queremos señalar en este breve retrato de cómo fue la concepción de la institución monárquica en la Castilla del XV, está la noción de monarquía gótica. Con esta idea de goticismo nos referimos a la corriente ideológica que entroncar las raíces de lo hispánico en la época del dominio godo en la Península Ibérica, época que se idealiza a modo de narración mítica fundacional y de la cual se ensalzan hitos como la reunificación de cinco reinos ibéricos y el papel de reyes como Leovigildo (que reinó del 572 al 586 y llevó a cabo una suerte de reunificación territorial), Recaredo (que reinó del 586 al 601 y materializó la unidad religiosa de la Península bajo el catolicismo), Suintila (que reinó del 621 al 631 y consolidó la unificación de los territorios hispánicos al expulsar a los últimos suevos y bizantinos) o Sisenando (que reinó del 631 al 636 y que convocó el IV Concilio de Toledo, dirigido por San Isidoro de Sevilla y del cual emanó el Fuero juzgo). Está idea de monarquía gótica quedará fuertemente ligada a un sentimiento patriótico castellano — en una atmósfera de eclosión de un sentimiento nacionalista que desarrollaría ya plenamente a lo largo de la modernidad - y a la subsiguiente defensa de la autonomía de la monarquía castellana dentro de los equilibrios de poder internacionales. Así lo explica Francisco Castilla: «En efecto, los letrados castellanos se empeñarán en mostrar que su reino es independiente del Imperio en virtud de sus orígenes godos, y le otorgarán un carácter unitario, pretendiendo representar no sólo a Castilla, sino a España entera ${ }^{217}$. Es interesante cómo en Castilla, ya sobre todo a partir del siglo XVI, se vertebró este vínculo fuerte entre monarquía y patria, asociándose reino y patria, ambos ligados además a una identidad religiosa y a un espacio territorial. Este patriotismo se justificó teniendo en cuenta la herencia unitaria de los godos, y en base a ello se articuló la moderna idea de proto Estado-nación con la vetusta idea mítica de la monarquía gótica anclada en la tradición textual historiográfica (esta idea de monarquía gótica se refundará a partir de los Reyes Católicos bajo la noción de monarquía hispánica). De nuevo con el profesor Castilla ${ }^{218}$ :

Los elogios de la tierra hispana que figuraban en el De laude Spaniae de san Isidoro, síntesis a su vez de los comentarios clásicos sobre la fertilidad y riqueza del país, fueron aprovechados siglos después por cronistas como Lucas de Tuy y el arzobispo de Toledo, Rodrigo Jiménez de Rada [ambos en el siglo XIII], para, con el añadido de nuevos elementos religiosos y culturales, reivindicar la importancia no sólo del territorio ocupado por uno de los reinos peninsulares, como era Castilla, sino de España entera (...)

\footnotetext{
${ }^{217}$ Castilla (2012): 139.

${ }^{218}$ Castilla (2012): 143.
} 
El propio Alonso de Cartagena, estaba embebido de este goticismo, el cual usó como argumento en defensa de Castilla y de la pertinencia e historia de la monarquía hispánica en sus labores diplomáticas en el ámbito del Concilio de Basilea. Lo vemos reflejado en escritos suyos como De preeminentia o Discurso sobre la precedencia del rey de Castilla sobre el de Inglaterra (1434), Tractatus super legem Gallus (1433), Proposicio facta coram domino Rege Romanourm (1434), o las Allegationes super conquesta Insularum Canariae contra Portugalenses (1436 o 1437); volveremos a esto en el Capítulo 3. Bajo tal concepción, en el contexto Cartagena, la figura del rey suponía el aglutinante de estas variables: patria, territorio, reino, tradición mítica e identidad religiosa. Por ello, como explica Kantorowicz, el monarca no sólo había de ser ejecutor del poder temporal (y ser asumido como una entidad simbólica que encarnaba la salvaguarda de la dimensión mítica y capacidad unificadora de la propia institución monárquica), sino que tenía encargada también la salvaguarda de lo espiritual al ser vicario de Cristo; de ahí que tuviera el cometido divino de velar por la Iglesia (es la conocida como 'teoría de las dos espadas') ${ }^{219}$.

Además de la idea tradicional del rey como vicario de Cristo —que por su puesto también operaba en Castilla-, la cuestión concreta del monarca como defensor del cristianismo y promotor de una guerra justa contra los infieles (algo explicable en el contexto hispánico histórico de Reconquista) fueron el caldo de cultivo perfecto para contribuir al fortalecimiento de la visión providencialista del monarca, el cual tenía un cometido divino de hacer la guerra contra paganos y herejes y expandir la fe católica, incluso hasta conquistar Jerusalén. Y, precisamente, ése era el reto propagandístico: que en la propia persona del rey se condensase todo lo que representaba el concepto de monarquía. Una propaganda de enaltecimiento del monarca virtuoso cuyo fin era la adhesión popular.

Considerando todo lo anteriormente expuesto en este apartado - además de muchas veces por cuestiones prácticas propias de sus cargos como consejeros y hombres de Estado- no es de extrañar que estos intelectuales conversos defendieran recurrentemente la institución monárquica.

\footnotetext{
${ }^{219}$ Kantorowicz (1985). Se recomienda esta lectura para ampliar infomación al respecto.
} 
Durante todo el convulso siglo XV castellano hubo una gran actividad en la elaboración de materiales intelectuales y culturales diversos que pivotaban en torno a la reflexión sobre la naturaleza del poder real y la monarquía, una monarquía que avanzaba hacia la expansión y la emergencia del Estado nación moderno. Hecho que sin duda ya se percibe en cómo la tratadística aborda ya la figura de los Reyes Católicos: su autoridad se asumía como sólida, punto éste que no se afrontaba para muchos de un modo negativo, pues creaba estabilidad, consenso y corporativismo. Con los Reyes Católicos y el comienzo de la llamada monarquía hispánica, emerge un potente engranaje cultural de exaltación monárquica, que no por ello dejará de ser vigilante sobre si los monarcas cometen un acto de arbitrariedad en contra de su esperable comportamiento virtuoso.

Retrocediendo, sin embargo, unas décadas a los tiempos de Alonso de Cartagena, y teniendo en cuenta todo lo expuesto en este punto, podemos afirmar que los intelectuales que formaron parte de lo que venimos llamando pensamiento político converso castellano del siglo $\mathrm{XV}$ - con Alonso de Cartagena como una de sus figuras principales - compartieron los rasgos que hemos presentado en este apartado en su concepción de la monarquía. Lo que intentamos explicar es que, tal y como lo entendemos, en la idea de monarquía propia de estos intelectuales se funden, como si de un sincretismo se tratase: elementos republicanos y constitucionalistas (en cuanto al origen de la autoridad real y a la conveniencia de poner límites al ejercicio de la autoridad real) + elementos de la teoría del principado organicista + idea providencialista del rey como vicario de Cristo (lo cual, recordemos no implica un enfoque teocrático) + mesianismo y profetismo de origen semítico y propio de los conversos + visión tradicional patriótica y gótica castellana del monarca. Obviamente, en cada pensador y/o cada circunstancia los porcentajes de cada una de estas variables oscilará, pero, estimamos que la coexistencia de todo ello determina una específica concepción de lo monarquía en el pensamiento político converso castellano del siglo XV que nos ocupa. 


\subsection{El proyecto de un modelo de gobierno mixto. Las Cortes en Castilla durante el siglo XV: de las Cortes de Briviesca a la Junta de Ávila.}

En este apartado mostraremos que la práctica de poner límites a la autoridad real es heredera en Castilla de una larga tradición medieval de convocatoria de Cortes o Estados Generales, en una suerte de lo que podríamos denominar 'parlamentarismo' o 'pactismo'. Éste recoge el corporativismo urbano que había marcado la noción de ciudad medieval. Dicho parlamentarismo era un elemento consustancial a la concepción de la monarquía de muchos de estos los pensadores conversos castellanos en el siglo XV y principios del XVI, concepción que promovía ya una suerte de gobierno mixto. Están de acuerdo con nosotros en esta cuestión, diversos estudiosos que están realizando en la actualidad interesantes trabajos al respecto. Estos trabajos tratan también sobre el republicanismo en general en la Castilla del momento ${ }^{220}$. Escribe, por ejemplo, Joan Pao Rubiés que en el ámbito hispánico el pensamiento de índole constitucionalista y su idea de gobierno mixto no han recibido la justa atención, y que esto no debería ser así y habría que abordar estudios comparativos entre el constitucionalismo y el republicanismo castellano y el de otros lugares europeos. Apunta, asimismo, Rubiés que en Castilla el constitucionalismo legitimó un modelo pactista basado en pensamiento neotomista ${ }^{221}$.

Intentamos, asimismo, aclarar en este apartado que estos intelectuales conversos que nos ocupan, siendo defensores de la institución monárquica tenían también una vocación republicana y constitucionalista en cuanto a la cuestión de los límites jurídicos e institucionales en el ejercicio del poder real y patrimonial, y en cuanto a la posibilidad de participación cívica de los distintos grupos políticos. Estos pensadores harían suya la máxima romana que recoge el Código de Justiniano y que habían transmitido los canonistas medievales: Quod omnes tangit ab omnibus approbari debet («Lo que concierne a todos debe ser aprobado por todos»), máxima que sintetizaba una tradición política basada en que lo que a todos afecta a todos concierne ${ }^{222}$. Y que, de acuerdo a lo que asevera Maurizio Viroli, justificaría la posterior consultación

\footnotetext{
${ }^{220}$ Pensamos en autores como: Gil Pujol (2002), Centerno (2012), Ruiz (2013), Villacañas (2017) (2005), Aranda y Rodrigues (2008), Egío (2014), Marcano (2000), Clavero (1986), Rubiés (1996), Martín Gómez (2018), Férnandez Albaladejo (1992), Thompson (1981), Fernández-Santamaría (1997), Flórez (2007), Alonso (2007), o Peña (2000).

${ }^{221}$ Rubiés (1996).

222 Villacañas (2014).
} 
democrática ${ }^{223}$. Como en seguida expondremos, este 'parlamentarismo' castellano en el siglo XV no fue un anhelo que prendió sólo como elaboración intelectual, sino también como proyecto político, aunque finalmente no pudiera implementarse.

Es destacable la larga tradición de Cortes en Castilla: se suele fijar el inicio de ésta ya en 1188 en las Cortes de León convocadas por Alfonso XI, y en las que fueron ya llamados todos los estamentos, incluso el pueblo llano (los homes bonos). Se ha afirmado en la Declaración de la Unesco que otorga a León la distinción como ciudad cuna del parlamentarismo que «Estas cortes suponen el origen del sistema parlamentario». El lugar de celebración y la periodicidad de las Cortes no era fijo, pero eran bastante frecuentes (podría decirse grosso modo que anuales), y en ellas se convocaba, además de a los estamentos sociales, a las entidades territoriales (ciudades y villas) y a las entidades corporativas ${ }^{224}$. Hasta la llegada de los Austrias, las Cortes o Estados Generales eran constituidas con frecuencia y para multitud de decisiones, las cuales habían de ser aprobadas en Cortes, requisito sin el cual el monarca no podía ejecutarlas. Se discutían en Cortes cuestiones fiscales y económicas, nombramiento de cargos, matrimonio y coronación de

\footnotetext{
${ }^{223}$ Viroli (2015): p. 68.

${ }^{224}$ Exponemos a continuación una relación de las Cortes celebradas en Castilla desde finales del siglo XIV hasta principio del siglo XVI. Cortes celebradas durante el reinado de Juan I (1379-1390): Cortes de Burgos de 1379, Cortes de Soria de 1380, Cortes de Segovia de 1383, Cortes de Valladolid de 1385, Cortes de Segovia de 1386, Cortes de Briviesca de 1387, Cortes de Palencia de 1388, Cortes de Segovia de 1389, Cortes de Guadalajara de 1390, Cortes de Segovia de 1390. Cortes celebradas durante el reinado de Enrique III (1390-1406): Cortes de Madrid de 1391, Cortes de Burgos de 1392, Cortes de Madrid de 1393, Cortes de Segovia de 1396, Cortes de Tordesillas de 1401, Cortes de Valladolid y de Tordesillas de 1401, Cortes de Toledo de 1402, Cortes de Valladolid de 1405, Cortes de Toledo de 1406 Cortes celebradas durante el reinado de de Juan II (1406-1454): Cortes de Guadalajara de 1408, Cortes de Valladolid de 1409, Cortes de Valladolid de 1411, Cortes de Medina del Campo de 1418, Cortes de Madrid de 1419, Cortes de Valladolid de 1420, Cortes de Tordesillas de 1420, Cortes de Ávila de 1420, Cortes de Ocaña de 1422, Cortes de Valladolid de 1425, Cortes de Palenzuela de 1425, Cortes de Toro de 1426, Cortes de Zamora de 1427, Cortes de Valladolid de 1429, Cortes de Burgos de 1429, Cortes de Medina del Campo de 1430, Cortes de Salamanca de 1430, Cortes de Palencia de 1431, Cortes de Medina del Campo de 1431, Cortes de Zamora de 1432, Cortes de Madrid de 1433, Cortes de Medina del Campo de 1434, Cortes de Madrid de 1435, Cortes de Toledo de 1436, Cortes de Madrigal de 1438, Cortes de Valladolid de 1440, Cortes de Toro de 1442, Cortes de Valladolid de 1442, Cortes de Burgos de 1444, Cortes de Olmedo de 1445, Cortes de Valladolid de 1447, Cortes de Valladolid de 1448, Cortes de Valladolid de 1451, Cortes de Burgos de 1453. Cortes celebradas durante el reinado de Enrique IV (1454-1474): Cortes de Cuéllar de 1455, Cortes de Córdoba de 1455, Cortes de Madrid de 1462, Cortes de Toledo de 1462, Cortes de Salamanca de 1465, Cortes de Madrid de 1467, Cortes de Ocaña de 1469, Cortes de Santa María la Real de Nieva de 1473 Cortes celebradas durante el reinado de Isabel I (1474-1504): Cortes de Segovia de 1474, Cortes de Medina del Campo de 1475, Cortes de Madrigal de 1476, Cortes de Toledo de 1480, Cortes de Toledo de 1489, Cortes de Ocaña de 1499, Cortes de Sevilla de 1499, Cortes de Sevilla de 1501, Cortes de Toledo, Madrid y Alcalá de 1502-1503 Cortes celebradas durante el reinado de Juana I (1504-1517): Cortes de Toro de 1505, Cortes de Salamanca y Valladolid de 1506, Cortes de Madrid de 1510, Cortes de Burgos de 1511, Cortes de Burgos de 1512, Cortes de Burgos de 1515. Reinado de Carlos I (1516 -1556), señalo sólo las celebradas hasta la revuelta comunera: Cortes de Valladolid de 1518, Cortes de Santiago y La Coruña de 1520. Tomo esta información de Colmeiro (1883).
} 
monarcas, cuestiones hereditarias sobre los mismos, relaciones entre ciudades y poder regio central, concesión de privilegios, pertinencia de las intervenciones militares, regulación de gremios, relación con los obispados, cuestiones territoriales, etc. En definitiva, se organizaba la gobernanza y se consolidaba el pacto rey-reino, además, procesualmente, se iban concretando y actualizando sus características. Sin embargo, se ha solido apuntar que, sobre todo tras la revuelta comunera de 1521, quedaron mermadas las funciones de las Cortes como controladoras de la autoridad regia. De todo modos, hay que hacer notar lo que explica esta cita de Francisco Quijano: «Buscando desmontar esta narrativa, a fines del siglo pasado apareció una serie de estudios centrados en las Cortes y otros mecanismos de negociación entre la Corona y las corporaciones de dichos reinos que mostraron cómo durante los siglos XVI y XVI los reyes españoles continuaron gobernando bajo un régimen que los obligaba a pactar con los distintos cuerpos políticos y que contaba con límites puntuales a su autoridad» ${ }^{225}$. Para ampliar información general acerca de las Cortes castellanas pueden consultarse, por ejemplo los estudios de Carretero, Olivera, Jago o Fortea ${ }^{226}$.

Concordando con nuestra visión, José Luis Villacañas sostiene que en la Castilla del XV estuvieron presentes las ideas y las prácticas de orientación republicana, aunque estima dicho profesor que éstas últimas no lograron finalmente sedimentarse, pues el poder patrimonial constantemente amenazaba el anhelo de autonomía. En sus propias palabras ${ }^{227}$ :

El sentido de lucha consistía en garantizar alguna forma de vida civil bajo las nuevas formas de principado monárquico (...) Cuando, con estos elementos en mente, nos volvemos a la historia de los orígenes de la modernidad hispana, descubrimos dos cosas claras: que en España existían suficientes elementos de la tradición republicana como para que fuera posible caminar hacia alguna de las dos maneras de republicanismo que surgieron tras la crisis del primer siglo XVI. Y que, sin embargo, estas dos salidas quedaron bloqueadas.

Sin embargo, hay que señalar, asimismo, que si bien había insumos ideológicos en pro de una cierta parlamentarización formal en Castilla, los había también para la ausencia de ésta. Al respecto, es bien interesante estudiar - como ha hecho Nieto Soria - la evolución de la noción

\footnotetext{
${ }^{225}$ Quijano (2017): 35.

${ }^{226}$ Carretero (1988), Olivera (1986), Jago (2001), Fortea (1900).

${ }^{227}$ Villacañas (2002): 174.
} 
de poderío real absoluto ${ }^{228}$. Ésta era una cláusula cancilleresca que permitía al monarca actuar sobrepasando la ley, es decir, de un modo incontestable y autónomo, y que acabó deviniendo modelo político Trastámara, incorporando en el proceso la noción de absolutismo necesario (aunque, según vimos en el apartado previo, y tal y como indican autores como Henry Kamen, o Perry Anderson esto no implicara necesariamente un gobierno fuerte) pero sí, en relación con lo que estamos apuntando ahora, cierta legitimación jurídica para el ejercicio del poder real sin control institucional ${ }^{229}$. Asevera José Manuel Nieto Soria ${ }^{230}$ :

Por todo ello, parece claro, tal como podrá comprobarse con mayor detenimiento, que el «poderío real absoluto» fue el símbolo por excelencia de la dimensión conflictiva de que la monarquía Trastámara se fue tiñendo en el trascurso del siglo xv. En consecuencia, referirse a la realeza castellana como sujeto de conflicto para este siglo comporta aludir necesariamente a la valoración que, desde una perspectiva de respaldo o de rechazo, recibió el «poderío real absoluto» en cada momento. Desde esta óptica, el período comprendido entre las Cortes de Olmedo, de 1445, y las de Ocaña, de 1469, que aquí será objeto preferente de consideración, resulta particularmente interesante por el nivel que alcanzó esta dimensión conflictiva.

En cualquier caso, este mismo estudioso habla también acerca de la importancia que el corporativismo — de índole urbana y republicana— tuvo en Castilla ${ }^{231}$ :

En el reino castellano, la doctrina corporativa tuvo una doble interpretación. La que podría denominarse personalizadora, que sería la primera en manifestarse, la que tuvo, por decirlo de alguna manera, un carácter oficial, siendo siempre apoyada desde los medios monárquicos (...) Frente a esta interpretación, existió la que denominaré transpersonalizadora. De aparición más tardía, tuvo una extraordinaria importancia política, por cuanto que estuvo en la base de las argumentaciones que justificaron las sublevaciones más importantes que, contra el poder real, tuvieron lugar en Castilla durante el siglo XV y comienzos del XVI.

Tal y como hemos venido repitiendo, el hecho de que la existencia de la monarquía se diese por hecho y se valorase y promoviese por estos pensadores políticos castellanos, no implica que estos letrados no tuviesen una clara impronta republicana y constitucionalista en cuanto a la

\footnotetext{
${ }^{228}$ Nieto (1998).

${ }^{229}$ Según estos estudiosos el absolutismo hispánico fue en el fondo débil en cuanto a control de los reyes sobre la nobleza, aunque fue fuerte en la dimensión simbólica. Anderson (1999), Kamen (2014).

${ }^{230}$ Nieto (1998): 161.

${ }^{231}$ Nieto (1998): 185, nota 93.
} 
necesidad de límites institucionales y de control jurídico en el ejercicio el poder real, y en cuanto a la conveniencia de participación cívica de los distintos grupos políticos. Este 'parlamentarismo' no sólo fue una apuesta teórica sino también se materializó como agenda política en busca de un modelo de gobierno mixto: ya estuvo muy presente en el espíritu de Cortes como las de Briviesca a finales del siglo XIV (1387), reverberó con fuerza en las de Olmedo (1445) u Ocaña (1469), y cristalizó —a la vez que constató su fracaso—en las Cortes de Burgos de 1506 y en el programa político de la Revolución Comunera, ya entrado el siglo XVI, en $1521^{232}$.

El apogeo de este espíritu pactista lo sitúa José Luis Villacañas en las Cortes de Burgos de 1506, convocadas por Felipe I (Felipe 'el Hermoso'), e indica que dicho rey compartía con estos letrados castellanos - sobre todo los letrados conversos que además se habían erigido en dirigentes urbanos - una enfoque republicano del reino y que tenía intención de promover el corporativismo urbano y el parlamentarismo. Sin embargo, el fracaso de estas Cortes por la temprana muerte del rey implicó el ocaso de este proyecto de gobierno mixto, proyecto que acabaría de apagarse con la derrota de los comuneros en Villalar. Así analiza Villacañas los acontecimientos ${ }^{233}$ :

Sin embargo, este monarca murió y esto implicó la disolución de las cortes, permitiendo el fortalecimiento de la nobleza señorial. Diego de Deza, el gran inquisidor, por encargo de Fernando [el Católico], desplegó entonces todo su tesón para intensificar la depuración racial de conversos, conscientes ambos de que ellos fomentaban los intentos de constitución del reino. Para eso destruyeron el espíritu de la conmunio urbana,

\footnotetext{
${ }^{232}$ Acerca de la revuelta de las Comunidades, recordar que la apoyaron sobre todo los representantes de las élites urbanas de las ciudades castellanas y su baja nobleza. Estos comuneros formaron un gobierno revolucionario, cuyo órgano máximo era la Santa Junta (o Cortes y Junta General de Reino), y que estaba en contra del monarca Carlos I, que se encontraba en Alemania y había dejado temporalmente al cargo del reino a Adriano de Utrech. Muy grosso modo podríamos sintetizar la cuestión así: los comuneros desaprobaban el modelo de reinado que planteaba Carlos I así como la injerencia extranjera en éste, y pretendían un modelo de gobierno que podríamos calificar como gobierno mixto en el cual las Cortes - que representaban a las ciudades y estamentos- compartieran el ejercicio de la autoridad y de las decisiones fiscales, militares, de nombramiento de cargos, de gobierno municipal, etc. con el monarca. Se promovía que la autoridad real quedase supeditada a la de las Cortes y se planteaba una suerte de modelo constitucionalista, ya que el monarca había de acatar La Ley Perpetua del Reino De Castilla. Los comuneros asumieron como su reina a Juana I de Castilla. Suele acotarse el apogeo de este movimiento entre 1519 y 1521. Finalmente, este proyecto político y la revuelta quedaron anulados tras la derrota comunera en la batalla de Villalar en 1521, donde fueron ajusticiados sus líderes Juan Bravo, Juan Padilla y Francisco Maldonado. Para ampliar información, pueden consultarse por ejemplo: Maravall (1994), Tierno Galván (1971), Baelo (2007), Castillo (1986), Peralta (2010), o Megías (1992).

${ }^{233}$ Villacañas (2017): 21.
} 
reintroduciendo la magia de la sangre y las diferencias sagradas de cristiano viejo y una forma de justicia inquisitorial antiforal. Cuando en la ausencia del rey, y en el clima de incertidumbre de 1520 , estalló el movimiento comunero, en el fondo se trataba de desplegar el programa de Burgos. Pero carente del cemento del rey, el espíritu corporativo de Castilla no era lo suficiente fuerte como para definir el sentido del reino. Arrasada la nueva mentalidad conversa por la Inquisición, no se tenía un espíritu afín capaz de unir a las élites de las ciudades.

Respecto a la revuelta de las Comunidades castellanas expertos como José Antonio Maravall o Pablo L. Alonso Baelo la consideran la como un evento propiamente revolucionario y constituyente, el cual pretendía implementar un verdadero modelo de gobierno mixto de inspiración republicana ${ }^{234}$. Una obra importante en esta línea es el Tratado de la república del trinitario Alonso de Castrillo, escrita precisamente en 1521, y la cual en estos días está siendo recuperada con intensidad como objeto de estudio, sobre todo por su papel como inspiración para las Comunidades. Aprecia Pablo L. Alonso Baelo que esta obra es la última y la más importante manifestación del republicanismo político en Castilla ${ }^{235}$. En su trabajo sobre la obra de Castrillo, el estudioso José J. Megías, señala que Castrillo estuvo involucrado con los comuneros, los cuales «pretenden de los procuradores en Cortes posean verdadero poder decisorio, de modo que dejen de ser pasivamente convocados a Cortes cuando los Reyes quieran, para negociar con el rey una exacción concreta. Pretenden, al menos en sus escritos, que sean las ciudades y villas las que convoquen Cortes, y muchos historiadores entienden que se comienza a perfilar, en un plano popular, la idea de pueblo como titular del poder» ${ }^{236}$.

La Junta de Procuradores del movimiento comunero, en representación de las ciudades castellanas, se reunió en 1520-1521 en la ciudad de Ávila en un junta extraordinaria - la Santa Junta de Ávila - que tenía carácter de Cortes Constituyentes (no convocadas por el monarca) y elaboró La Ley Perpetua del Reino De Castilla, un texto que podemos entender como un precedente constitucional hispánico. Esta ley se redactó como un marco normativo que había de acatar incluso el rey, el cual no podía variar su contenido, al igual que no lo podían hacer unas Cortes ordinarias. En La Ley Perpetua del Reino De Castilla el monarca aparecía ella como protector ejecutivo del reino, pero se determinaba la independencia y capacidad de decisión en el

\footnotetext{
${ }^{234}$ Maravall (1994), Alonso Baelo (2007).

${ }^{235}$ Baelo (2007).

${ }^{236}$ Megías (1992):14.
} 
gobierno de las Cortes, entendidas como una asamblea que representa a las ciudades y estamentos. En este proyecto político que promovían las Comunidades, las Cortes tendrían un papel mucho más relevante que en el previo reinado de los Reyes Católicos: se estaba promoviendo un verdadero modelo de gobierno mixto. El estudioso del tema, Ramón Peralta, resume así el contenido de dicha ley ${ }^{237}$ :

Se fijan las funciones y modos de elección de los diputados como portavoces de los Concejos; se declara la independencia y profesionalidad de los jueces; se reestructura la administración estableciéndose criterios de selección y controles objetivos; se establecen específicas garantías judiciales en favor de la libertad y derechos de los ciudadanos y se reordenan los derechos de nacionalidad; se establece una Hacienda Pública y un orden económico en beneficio del desarrollo material del reino, de su producción y su comercio; se prohíbe la injerencia de los extranjeros, excluyéndose a éstos del ejercicio de cualquier cargo público; se garantiza, en fin, una amplia autonomía local-territorial en favor de Concejos y Comunidades cuyas autoridades eligen los vecinos, excluyéndose toda injerencia regia.

Con esta ley, que condensaba las peticiones de los comuneros y era la cristalización jurídica de la revuelta comunera contra Carlos I, en opinión, asimismo, de Peralta, «El pueblo castellano pretendía establecer formalmente la primera monarquía constitucional, sin embargo, el rey y una corte de extranjeros apoyados por determinados sectores directamente beneficiarios del nuevo orden cesarista combatieron aquella pretensión logrando, con el tiempo, desvirtuar la estructura jurídico-política castellana, que tuvo que adaptarse a un molde foráneo de índole monárquico-absolutista» ${ }^{238}$.

Reproducimos aquí un fragmento de las peticiones de los comuneros en la Santa Junta de Ávila de 1520-1521, en éste se puede apreciar cómo la acción del rey quiere ser limitada por las Cortes $^{239}$ :

Quel rey no pueda poner Corregidor en ningun logar, sino que cada ciudad é villa elijan el primero dia del año tres personas de los hidalgos é otras tres de los labradores, é questos dos que escojeren sean alcaldes de cevil é criminal por tres años ( $\cdots)$ Quel rey no pueda sacar ni dar licencia para que se saque moneda ninguna del reino, ni pasta de oro ni

\footnotetext{
${ }^{237}$ Peralta (2010).

${ }^{238}$ Peralta (2010).

${ }^{239}$ Maravall (1994), Alonso Baelo (2007) Peralta (2010).
} 
de plata (...) Quel rey no pueda dar licencia para que se saque pan ni carne fuera del reino sin el permiso de las Cortes y en caso de sacarse, lo que se pague de ellos que no pueda ser tomado por el rey (...) Quel rey quite todos los oficios, beneficios, dignidades y encomiendas a las personas que no son nascidas y bautizadas en el reino (...) Que cuando el rey quisiese hacer la guerra llame a las Cortes a los procuradores y diga la causa que ellos vean si es justa o injusta. (...) Que cada é cuando alguno hubiere de suceder en el reino, antes que sea rescibido por rey $(\cdots)$ confiese que rescibe el reino con estas condiciones.

La existencia de una base comunitaria - la cual fuera asimismo comunidad política participativa, tal y como promueven los ideales republicanos - es cierto que quedó en Castilla reducida a una identidad de homogeneidad católica, y que uno de los elementos que anuló la posibilidad de ese sedimento comunitario fue que lo republicano se asoció a lo converso. Es interesante pensar acerca de la diferencia entre los conceptos de "comunidad" e "identidad". La maquinaria de la exclusión comenzaba a fagocitar a la ratio de la inclusión que la filosofía política de autores como el que nos ocupa, Alonso de Cartagena, quiso loablemente - y con la lucidez de quien tal vez otea el drama que viene- promover.

De acuerdo con lo que lúcidamente señalan Javier Cárdenas y Enver Torregroza, a quienes parafraseo aquí, el conflicto sobre la identidad histórica de los pueblos hispánicos aparece como uno de los problemas fundamentales de la filosofía política hispánica, y es una problemática que no podía intentar resolverse imponiendo una identidad colectiva mediante la exclusión $^{240}$. Como explicaremos luego, no se logró en España consolidar el sentido de comunidad que ha de ser inherente a la puesta en marcha de un gobierno con rasgos republicanos, cosa que sí sucedió en mayor medida, según Villacañas, en la Europa protestante $^{241}$. No es que en el mundo protestante y en el Norte de Europa se diese una arcadia de ciudadanía, libertad y carencia de represión, pero sí entendemos que es verdad que el discurso oficial del poder sí perfiló, quizá sólo propagandísticamente, un discurso de "invitación" a la construcción de ciudadanía y de consolidación de base política, de comunidad política, de sustrato corporativo. Quizá sólo como discurso de producción hegemónica (uso aquí este término en su sentido grasmciano), pero es cierto que en la retórica política del Norte de Europa y el ámbito anglosajón la creación de comunidad política, tanto a través de agentes individuales

\footnotetext{
${ }^{240}$ Cárdenas y Torregroza (2011): 8.

${ }^{241}$ Villcañas (2005).
} 
formándola, como de instituciones de talante participativo, estuvieron presentes en la consolidación del republicanismo y liberalismo modernos. Primero las ciudades asociadas, en lugares como la Suiza calvinista, por ejemplo, y luego los estados nación del Norte de Europa, se concibieron como un proyecto colectivo de construcción de ortodoxia: el pueblo participaba de esta construcción, no sólo acataba una ortodoxia y una identidad impuestas ${ }^{242}$. Y es así como se introyectó su auto-percepción como ciudadanos. El corporativismo religioso que logró aglutinar la Reforma protestante fue capaz de preservar y fortalecer el republicanismo medieval. No fue así la deriva del discurso oficial político castellano, que, sin embargo, amainó su republicanismo tan vivo entre los conversos del siglo XV. Otra cosa sería, sin embargo, la presencia de este republicanismo en el ámbito intelectual y en el gobierno de facto de algunos entes políticos, tanto en España como en Hispanoamérica.

Es de justicia afirmar que aunque el proyecto republicano no pudo llegar a implementarse plenamente en Castilla y se vio truncado como proyecto político de un gobierno mixto, su impronta intelectual se perpetuó en universidades, teólogos, filósofos y juristas, y pervivió, en mayor o menor medida, su traductibilidad material en la relación de entidades como municipios, gremios, u órdenes religiosas con la monarquía. Coincide con nuestra opinión Francisco Quijano en su siguiente observación ${ }^{243}$ :

Una revisión más amplia de las fuentes escolásticas de la época nos lleva necesariamente hacia otras conclusiones. Si bien es cierto que la derrota del movimiento comunero significó un golpe decisivo a un proyecto político y social fundamentado en los presupuestos republicanos antes descritos, la victoria de Carlos V sobre el movimiento de las comunidades, como veremos más adelante, no significó el surgimiento de una tradición absolutista en la Monarquía hispánica que anulara cualquier posibilidad de crítica.

Por ello, al igual también que Quijano, no estamos de acuerdo con Ramón Ruiz o José Luis Villacañas en la opinión de que el republicanismo castellano no salió en absoluto bien parado en el tránsito a la Modernidad y de que «En Castilla, ya desde el XV se impusieron los poderes patrimoniales y señoriales frente al corporativismo republicano urbano que había

\footnotetext{
${ }^{242}$ Villacañas (2014).

${ }^{243}$ Quijano (2017): 57.
} 
marcado la noción de ciudad medieval» ${ }^{244}$. No pensamos, como sí hace Ruiz, que el espíritu republicano castellano sea una «tradición frustrada» y quedase pulverizado completamente tras Villalar $^{245}$. No se impuso como agenda política, pero esto no implica que desapareciese como impronta intelectual o de praxis política.

Ahora bien, dicho esto, y sin querer parecer ambivalente, es verdad que el tamaño de las repercusiones de la anulación del proyecto de convivencia e inclusión propio los conversos aún hoy no somos capaces de sopesarlo. Opinamos, como plantearemos en la conclusión de este texto, que ciertas especificidades de la modernidad hispánica emanan reactivamente de la anulación de este proyecto político integrador del pensamiento político converso. No es ésta una cuestión baladí, pues el destino de España estaría marcado en mucho por la marginación de los judíos, los conversos, los marranos, y también de los musulmanes peninsulares (los llamados moriscos), quedando tantas veces la mirada crítica de todos ellos condenada a espacios de soledad u ocultamiento, de heterodoxia y disidencia intelectual, pues fue marginada entonces, silenciada y tergiversada después, y aún hoy desconocida, minusvalorada e incomprendida ${ }^{246}$.

Es la marginación de este republicanismo converso y la legitimación de una práctica de exclusión como ratio de Estado lo que imposibilitó la consolidación de una base comunitaria que deviniese comunidad política, y esta ratio de la exclusión y de la dominación, creemos que permeó en las subjetividades políticas de la población castellana. Ésta introyectó una noción defectiva de ciudadanía, pues sin una universitas no es posible que florezca y se implemente un verdadero republicanismo. Pensamos que una obra como el Defensorium unitatis christianae de Alonso de Cartagena, que analizaremos más adelante, quería neutralizar esto: no estaba en juego sólo una cuestión teológica o de protección de los conversos, sino un modelo político y una racionalidad política de la inclusión en lugar de una de la exclusión.

Estimamos que el Defensorium no ha sido encarado encontrando en su teología política elementos republicanos. Hasta donde sabemos, no se ha hecho una lectura de este texto

\footnotetext{
${ }^{244}$ Villacañas (2017): 19.

${ }^{245}$ Ruiz (2013).

${ }^{246}$ Terminando abocada su mirada muchas veces al espacio subjetivo de la literatura, siendo ésta una suerte de reducto, como ha venido indicando reiteradamente la historia social de la literatura española, y como señala también, por ejemplo, Leo Strauss en su libro La persecución y el arte de escribir. Strauss (2009).
} 
considerándolo también en clave republicana (algo que pretendemos sea uno de nuestros aportes con esta tesis). Y esto ha sido así tal vez por su defensa de la ortodoxia y su alabanza al rey algo que, como hemos repetido, no es excluyente con los valores republicanos, pero que quizá se ha prejuzgado así-. Además, pensamos que la comprensión de esta obra sólo en clave apologética es fruto de una lectura poco profunda y que no tiene suficientemente en cuenta, como veremos, tópicos formales propios de una obra del siglo XV redactada por un hombre de Iglesia y de Estado. Y que tampoco tiene en cuenta el que era una 'obra de circunstancia', o el que en los textos escritos por conversos - siempre temerosos en la forma de enunciar sus posturas dado su origen - conviene hacer una lectura entre líneas. Dicho texto tiene muchas capas y aristas, y sostenemos que en la teología política que entraña sí hay elementos republicanos, sobre todo en relación con nociones como las de la participación y la libertad. Estos elementos no sólo es que estén presentes, sino que son cruciales, pues se emplean para argumentar la necesidad de inclusión y no discriminación de los conversos, y para promover otra racionalidad política diferente a la que desde el poder estaba consolidándose. Estas capas son las que pretendemos visibilizar: esos pliegues en los que el autor aúna principios del pensamiento político (tales como el acceso a la ciudadanía, la participación, o el organicismo) con lo religioso, materializando todo ello en una idea de inclusión, esto es, de creación de un nuevo pueblo cristiano cohesionado, que es además base comunitaria — que es comunidad políticaaunándose la idea de república cristiana con la de república civil. Pasamos ahora en la segunda parte de la tesis a abordar a este autor y esta obra, la cual entendemos como epítome de este pensamiento político converso cuya existencia y especificidades hemos querido demostrar en el Capítulo 1 y cuyo contexto intelectual y socio-político, que es su condición de posibilidad, hemos querido plantear en este Capítulo 2, conformando ambos la primera parte de este trabajo. Pasemos ahora a la segunda parte, la cual abordará ya la figura de Alonso de Cartagena y el análisis del Defensorium unitatis christianae.

\section{Conclusiones y aportes del Capítulo 2}

Hemos mostrado someramente en esta capítulo algunas variables que conforman el contexto intelectual y socio político del siglo XV castellano, las cuales se influyen y retroalimentan entre sí. Estos ejes en base a los cuales hemos abordado dicho contexto, nos han permitido ver que 
son los que catalizan la existencia de lo que venimos llamando pensamiento político converso y los que determinan su especificidad. El análisis de dichos ejes nos ha permitido ver cómo éstos son su condición de posibilidad: su caldo de cultivo filosófico y espiritual, así como la horquilla de problemas y circunstancias políticas e históricas que este pensamiento político converso trataba de solucionar y sobre el que reflexiona. Estos ejes que hemos tomado como aristas para el análisis han sido: 1) La cuestión conversa, 2) La función social del letrado, 3) La Primera Escuela de Salamanca. Escolástica y pensamiento político, 4) Proto-reforma, paulinismo, organicismo teológico y conciliarismo en Castilla, 5) La noción de monarquía y 6) El proyecto de un modelo de gobierno mixto. Las Cortes en Castilla durante el siglo XV: de las Cortes de Briviesca a la Junta de Ávila.

Teniendo en cuenta la información contenida en este capítulo, el lector está ya capacitado para comprender el origen de las particularidades de este pensamiento político converso. Éste estuvo conformado por letrados de formación escolástica y de ascendencia conversa en su mayoría (con la problemática que esto último entrañaba); vinculados a la Universidad de Salamanca y a la administración, y con contactos internacionales (sobre todo gracias a los concilios); practicantes de una religiosidad proto-reformista (mística, universal, paulina); adheridos a concepciones organicistas del principado y defensores de la monarquía — gótica, providencialista y profética, pero no teocrática, arbitraria, ni absoluta-; y atravesados de valores republicanos y constitucionalistas (en cuanto al origen y límites de la autoridad, la vocación parlamentarista, la importancia otorgada a la participación, la libertad, la no exclusión, y la virtud civil vía el vivere civile).

Unos intelectuales que, pese a fracasar en su proyecto político de gobierno mixto, dejaron una enorme impronta intelectual en la conformación del pensamiento hispánico. Intelectuales, además, hacedores de una sugerente articulación entre lo teológico y lo republicano (mancuerna en la que se engarzan teleología cristiana de la salvación y teleología republicana, communitas cristiana y comunidad política). Esta articulación es el hecho en el que más queremos incidir a lo largo de este trabajo, como ya apuntamos en el capítulo primero. Y queremos demostrar dicha articulación entre valores republicanos y valores religiosos como especificidad castellana, analizando nuestro texto objeto de estudio: el Defensorium unitatis christianae de Alonso de 
Cartagena. Él fue una de las principales figuras e inspirador en mucho de este pensamiento político converso, y el texto que nos ocupará será uno de los escritos más relevantes de los que cabrían bajo este rubro y un texto paradigmático de esta ligazón que venimos sugiriendo. Para poder entender este texto de Cartagena, era necesario retratar en la medida de lo posible el contexto que lo determinó, aporte que hemos realizado en el capítulo que ahora cerramos. En él, la idea ha sido destilar las particularidades del pensamiento político converso, las cuales constataremos a continuación al abordar nuestro estudio de caso, dando así paso a la segunda parte de este trabajo. 


\section{CAPÍTULO 3: Acerca de Alonso de Cartagena y su pensamiento político.}

\section{Introducción al Capítulo 3.}

Esta segunda parte de la tesis que ahora iniciamos se perfila como un estudio de caso - de un autor y una fuente principal de la época - cuyo objetivo es materializar y demostrar lo propuesto en los Capítulos 1 y 2, esto es, presentarlo en un soporte textual filosófico definido, completando así circularmente este trabajo.

Además, en este capítulo pretendemos cumplir otro de los objetivos de esta tesis: el visibilizar la figura de Alonso de Cartagena e introducir su pensamiento político. Así como cumplir el objetivo de ver cómo dicho autor se adecua y encarna las característica de lo que en los capítulos previos habíamos definido como pensamiento político converso. El desarrollo del actual capítulo será relevante no sólo para presentar y poner en valor a nuestro pensador, el cual, a pesar de que fue un personaje de gran importancia en su momento - y no sólo en Castilla, sino en toda Europa - ha caído en cierto descuido por parte de la academia, sino también para recuperarlo desde la óptica de su pensamiento político, ya que las veces que se lo ha abordado ha sido sobre todo desde la filología. Trataremos, asimismo, de demostrar que hemos de entender a Cartagena como una figura de transición epocal, que conjuga elementos propiamente renacentistas con la tradición escolástica medieval, y que aglutina en su persona rasgos de diversas tradiciones intelectuales y culturales (de ahí ciertas ambivalencias que la crítica ha visto en él y que, como explicaremos, nosotros no interpretamos como contradicciones).

Lo primero que hemos de realizar en este capítulo es una introducción a Alonso de Cartagena. Como decíamos arriba, éste, pese a haber tenido una importancia crucial en el siglo XV no sólo castellano, sino europeo (salve apuntar, a modo de ejemplo, que fue parte activa en concilios como el de Basilea, o amigo e interlocutor de pensadores clave en el pensamiento político del momento como Pier Candido Decembiro o Leonardo Bruni, así como de los Papas Eugenio IV, Nicolás V o Pío II), y pese a haber sido líder de la intelectualidad conversa y haber 
sido una figura clave como hombre de Estado y de Iglesia en la Castilla del XV, lamentablemente ha quedado descuidado por la historia intelectual. Ésta parece haber reproducido el abandono oficial que de su pensamiento se hizo en el siglo XVI debido a su raigambre conversa, aunque, como veremos, su herencia pervivió en el pensamiento hispánico.

En el primer punto haremos una primera aproximación al autor, tanto a su peripecia vital como a su producción textual. En el segundo nos centraremos en presentar su figura con una mirada que pretende ir más allá de la habitual concepción que la academia — salvo honrosas excepciones - tiene de Cartagena, prejuzgándolo sólo como un rigorista canónico y como un intelectual aferrado a la tradición medieval y cerrado a nuevos aportes (falsa imagen a nuestro criterio, que ha sido motivada en mucho por la interpretación que se ha hecho de la polémica que tuvo con Leonardo Bruni acerca de la mejor manera de traducir la Ética de Aristóteles). Rescataremos, y con eso damos paso a la tercera sección de este capítulo, algunas facetas de su pensamiento político (su teología política ya será abordada en el Capítulo 4). Básicamente nos detendremos en su capacidad de ligar el pensamiento político clásico con el cristianismo, en su recuperación de Séneca y Cicerón, en su aristotelismo, en su defensa de la noción de servicio público ligada al valor republicano de desarrollo de vida activa en el vivere civile a través de la participación cívica en pro del bien común, en su conciliarismo, en la vocación pedagógica —en la línea de la enseñanza moral - de la que dotaba a sus trabajos, en su rigor jurídico y en su concepción de la monarquía. En este último punto nos extenderemos algo más, y comprobaremos que Cartagena defiende el origen popular de la autoridad real, la conveniencia de dotar de límites al ejercicio de ésta, una visión providencialista pero no teocrática del monarca, el organicismo monárquico, y elementos propiamente hispánicos en la idea de monarquía como el profetismo converso o el goticismo. Lo que queremos mostrar es que el pensamiento político de nuestro autor tiene más capas de las que se han señalado normalmente y que además incorpora elementos de enorme actualidad para su contexto.

Respecto a presencia en su pensamiento de elementos tales como su racionalidad política inclusiva, su apuesta por la creación de una comunidad política, la relevancia que este autor le da a la idea de participación, o su idea de igualdad —elementos que articula con lo teológico- nos detendremos ya en el Capítulo 4. 


\subsection{Presentación de Alonso de Cartagena y de su producción textual. Estado de la cuestión sobre la literatura crítica en torno al autor.}

Antes de continuar, conviene señalar que, lentamente, se está restaurando la figura de Cartagena y se está vinculando a la filosofía, a través de iniciativas como la Biblioteca Saavedra Fajardo de Pensamiento Político Hispánico (que ha editado y reseñado varios trabajos de Cartagena) o la revista Res publica, vinculadas ambas al Departamento de Historia de la Filosofía de la Facultad de Filosofía de la Universidad Complutense de Madrid, o gracias las Facultades de Filosofía de las universidades de Salamanca, Murcia o Alcalá de Henares. Como iremos comprobando a lo largo de este capítulo (y dando las referencias pertinentes), se han detenido últimamente en su pensamiento relevantes profesores como por ejemplo José Luis Villacañas, Luis Fernández Gallardo, Francisco Castilla, Fernando Miguel Pérez Herranz, Enver Torregroza, María Morrás, Rafael Herrera, Javier Cárdenas o Stefania Pastore ${ }^{247}$. Entre los estudiosos que han trabajado y reivindicado a nuestro autor desde los estudios filológicos cabe destacar a Ottavio Di Camillo, Marcelino Menéndez Pelayo, Tomás González Rolán, Pilar Saquero, Ángel Gómez Moreno, o Jerónimo Miguel $^{248}$. Ya hace algunas décadas desde la Filología sí que se abordó a Cartagena, pero sobre todo en lo referente a su faceta como traductor de autores clásicos y a su controversia con Bruni acerca del mejor modo de realizar una traducción, hecho éste en el que nos detendremos después ya que es relevante al haberse entendido como una contienda entre dos métodos de conocimiento y dos formas de concebir la filosofía de la historia: la escolástica frente a la humanista. Mención aparte y especial reconocimiento para la factibilidad de este trabajo hemos de hacer al editor y al traductor del Defensorium unitatis christianae, Manuel Alonso y Guillermo Verdín-Díaz. Gracias a ellos, en 1943 y 2013, respectivamente, esta obra volvió a editarse casi cinco siglos después (algo muy sorprendente dada la importancia que tuvo en su momento) y por fin se ha tornado accesible ${ }^{249}$.

\footnotetext{
${ }^{247}$ Fernández Gallardo (2002) (2007), José Luis Villacañas (2017) (2014) (2012) (2012b) (2005) (2005c) (2004), Fernando Miguel Pérez Herranz, (2016), Guillermo Verdín-Díaz (1993), Francisco Castilla (2010) (2011) (2012), Enver Torregroza (2008) (2010) (2011), María Morrás (2002a) (2002b) (1996) (1995) (1991), Rafael Herrera, (2016), Javier Cárdenas (2011), o Stefania Pastore (2004).

${ }^{248}$ Di Camillo, (1976), Menéndez Pelayo (1995) (1952), González Rolán (1991) (1994) (1996) (200) , Saquero (1991) (2000), Gómez Moreno (1995), Miguel (2018).

${ }^{249}$ Alonso (1943) y Verdín-Díaz (2013).
} 
Dicho esto, comencemos por hacer un esbozo de rasgos biográficos de nuestro autor, cuyo nombre de pila, conviene señalar, algunos estudiosos toman como «Alfonso», pues tanto este nombre como «Alonso» están documentados y posiblemente se intercambiaran o asimilasen en vida del autor.

Alonso de Santa María — conocido como Alonso de Cartagena- nació y murió en Burgos (1384-1456, así reza su epitafio en la Catedral de Burgos), fue parte del intelectualmente importantísimo clan converso de los Santa María, también conocidos como "de Cartagena" (de origen hebreo y antes de la conversión al cristianismo llamados familia Ha-Levi). Dicho clan lo inauguró Pablo de Santa María (1353-1435, padre de Alonso) y también destacaron en él por sus escritos y actividad política y religiosa, Alvar García de Santa María (1370-1460, hermano de Pablo), Gonzalo de Santa María (1379-1448, hijo de Pablo y hermano de Alonso) o Teresa de Cartagena (c.1425-?, sobrina de Alonso) ${ }^{250}$. Como apuntamos, Alonso era hijo del patriarca de este clan, Pablo de Santa María, antiguo rabino de Burgos y conocido antes de su conversión como Salomón Ha-Levi. Se bautizó junto con sus hijos el 21 de julio de 1390, siendo Alonso un niño de corta edad. Pablo de Santa María insufló un claro ambiente intelectual en la familia, él se había doctorado en teología en la Universidad de París en 1394 y ya en 1415 fue nombrado obispo de Cartagena por Benedicto XIII, después pasaría a serlo de Burgos (cargo que luego ocuparía su hijo Alonso); asimismo, Pablo de Santa María fue Canciller de Castilla.

Volviendo a nuestro autor, Alonso de Cartagena, apuntar que estudió en la Universidad de Salamanca, doctorándose allí tanto en Derecho Civil, en 1414, como en Derecho Canónico algo después (parece que su formación universitaria como civilista fue más sólida). Nuestro autor fue parte activa en la importancia que tuvo este centro en la primera mitad del siglo XV y de su papel como espacio de introducción y generación de innovadoras posturas intelectuales y espirituales y de formación de letrados (tal y como hemos explicado en los puntos 2.2 y 2.3 del capítulo segundo). Además de ser un eclesiástico, un curial, que llegaría a ser obispo de Burgos (nombrado en 1435 después de otros cargos de menor rango en diversos destinos: en 1415 fue nombrado decano de la catedral de Santiago y en 1419 de la de Segovia), fue un hombre de

\footnotetext{
${ }^{250}$ Sobre Pablo Santa María, véase Torregroza (2010) y Serrano (1942). Acerca de Alvar García de Santa María, véase Cantera (1952).
} 
Estado muy ligado al rey de Castilla Juan II, realizando para él labores de consejero, auditor y diplomático. Esto le permitió viajar con frecuencia, tanto al Concilio de Basilea (donde fue parte delegación castellana entre 1434 y 1439 y donde ganó notable fama europea), como a embajadas, así la de Portugal, (con motivo del litigio entre Castilla y Portugal por el dominio de las Islas Canarias), la de Alemania (donde fue al morir Segismundo, Emperador del Sacro Imperio Romano Germánico, al cual Castilla no pensaba debía subordinar su cristiandad), o la de Navarra; y, gracias a ello, contactar de primera mano y enlazar amistad con pensadores de otros lugares, sobre todos italianos: por ejemplo con Pier Candido Decembrio o Poggio Bracciolini. También con Leonardo Bruni mantuvo una frecuente correspondencia. El peso y el prestigio de Alonso de Cartagena entre sus pares fue notable, de tal modo que podríamos decir que fue uno de los líderes a la élite intelectual de Castilla durante del siglo XV. En Basilea logró marcados éxitos diplomáticos como el derecho preferencial del rey de Castilla frente al de Inglaterra ante la Santa Sede, la paz entre el Emperador y el rey de Polonia o sus avances para conseguir compatibilizar las posturas conciliaristas que habían primado en el Concilio de Constanza con el poder papal.

Como mencionábamos arriba, Alonso de Cartagena fue una figura crucial en la Europa de su tiempo, así lo apunta este fragmento tomado de Marcelino Menéndez Pelayo «Éste es aquel insigne prelado que alcanzó los títulos de 'Delicias de la religión y único espejo de la sabiduría', aquél a quien apellidó Pío XII 'alegría de las Españas y honor de los prelados', aquél por quien exclamó Eugenio IV al saber que se dirigía a la capital del mundo cristiano: 'Por cierto que si el obispo de Burgos en nuestra corte viene, con gran vergüenza nos assentaremos en la silla de San Pedro’» ${ }^{251}$. En la misma línea de ensalzar su vasta sabiduría está escrito el poema laudatorios elegiaco que le escribió a su muerte su discípulo Fernán Pérez de Guzmán y del cual reproducimos un fragmento ${ }^{252}$ :

Aquel Séneca espiró / A quien yo era Lucilo, / La facundia y alto estilo / De España con él murió / Ansí que no solo yo, / Mas España en alto son / Debe plañir su Platón/ Que en ella resplandesció / (...) La Iglesia nuestra madre / Hoy perdió un noble pastor, / Las

\footnotetext{
${ }^{251}$ Menéndez Pelayo (1952).

${ }^{252}$ En Foulché R. (1912-1915): 677 (vol. 1, núm. 288).
} 
religiones un padre / Y la fe un gran defensor. / La moral philosofía, / Las leyes y los Decretos, / Los naturales secretos / De la alta filosofía, / La sacra Teología, / La dulce arte oratoria, / Toda veríssima historia, / Toda sotil poesía.

Podríamos afirmar que Cartagena lideró la élite intelectual en el siglo XV en Casilla, y que fue máximo representante de lo que venimos refiriendo a lo largo de este trabajo como pensamiento político converso. Aglutinó en torno a su persona a un grupo de intelectuales tan relevantes como Diego de Valera, Sánchez de Arévalo, Alonso de Palencia, o Fernando del Pulgar. También entre los literatos, eclesiásticos y nobles gozó de enorme peso. Es destacable cómo la nobleza ilustrada estuvo muy influida por él (por ejemplo el Íñigo López de Mendoza, Marqués de Santillana), pues se encargó de divulgar entre ellos el saber ético y promover un ethos del servicio público. Asimismo fue inspirador de la siguiente generación de grandes pensadores conversos, algo que vemos por ejemplo en el tratado De vita beata de Juan de Lucena. Es interesante recordar que el círculo intelectual que se estableció en torno a Cartagena no fue sólo un espacio de reflexión, sino que tuvo una dimensión política, esto es, configuró un programa político que promovía elementos de un gobierno mixto (cuestión ésta que vimos en el punto 2.6 del capítulo previo) y una racionalidad política en pro de la inclusión, la convivencia y la conformación de comunidad política.

Antes de referirnos a su producción textual, nos parece relevante mencionar que Cartagena no renunció ni quiso ocultar nunca su naturaleza conversa. Se enorgulleció siempre de sus orígenes judíos y fue consciente de los aportes que esta matriz intelectual semítica le suponían. Su seguidor Juan de Lucena, en su interesante diálogo De vita beata (o Diálogo sobre la vida feliz) de mediados de siglo XV, diálogo que supone, entre otras cosas, una defensa de los conversos y del cual Cartagena es un personaje, pone en boca de don Alonso - respondiendo a Juan de Mena, otro de los personajes — las siguientes palabras: «No pienses correrme por llamar los ebreos mis padres. Sonlo por cierto, y quiérolo: ca si antiguedat es nobleça ¿quién tan lexos? Sy virtud, ¿quién tan çerca?» ${ }^{253}$. Nuestro autor fue tremendamente sensible con las injusticias que afectaban a esta minoría conversa a la cual pertenecía, de hecho, éstas motivan su Defensorium, obra que analizaremos más adelante. Participó de las características propias del colectivo converso que expusimos en el apartado 2.2 del capítulo previo, de hecho, podemos

${ }^{253}$ Lucena (2014, edición de Jerónimo Miguel). Tomo aquí al cita de Pastore (2004): 42. 
aseverar que fue uno de lo líderes de la intelectualidad conversa, en realidad de toda la intelectualidad castellana, del siglo XV. Nuestro autor se perfila como epicentro de lo que hemos venido denominando pensamiento político converso, corriente cuyas características y catalizadores hemos estudiado en los capítulos anteriores y los cuales es fundamental tener en cuenta para poder comprender en toda su profundidad y sin juicios superficiales a Cartagena.

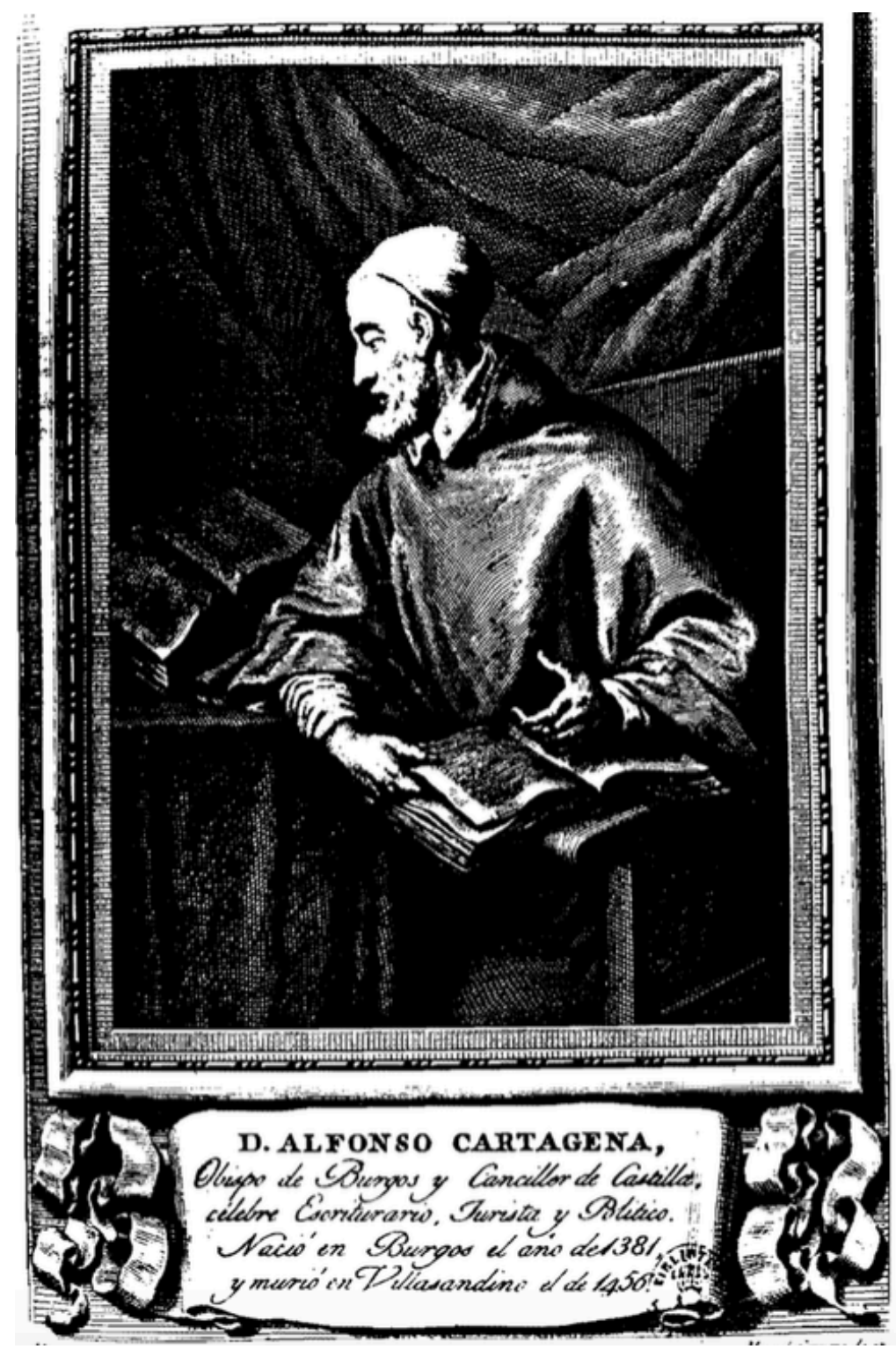

Reproducción del grabado Alfonso de Cartagena. Autor: Manuel Salvador Carmona, 1791. Colección Retratos de los españoles ilustres (1791), Madrid, Imprenta Real. 
Nuestro autor se desempeñó como traductor y escritor a lo largo de décadas, y pese a la diferencia de temáticas entre sus trabajos - incluso a pesar de la aparente evolución, o hasta de cierta incongruencia ideológica, entre ellos—, todos se ajustan a la configuración discursiva propia del paradigma escolástico, y todas participan de un riguroso formalismo. Indica la filóloga María Morrás que está su producción: «Encaminada a facilitar - y al tiempo controlar- el acceso al saber escrito, sus obras se caracterizan por un marcado carácter circunstancial y educativo, así como por la elección de un estilo exento de latinismos estridentes $»^{254}$. Apunta, asimismo, Morrás que «Si bien es cierto que todas y cada una de sus obras nacen como resultado de la petición o consulta de un personaje no lo es menos que el autor aprovecha para llevar al lector en la dirección que le parece apropiada» ${ }^{255}$. Juan Marichal afirma que los textos de Cartagena se alejan de la aridez del tratado medieval, y se acercan ya al modo ensayístico ${ }^{256}$.

Exponemos a continuación una relación de sus obras (sin incluir textos atribuidos o perdidos). Antes que nada, salve decir que los estudiosos que se han encargado de la transmisión textual de Cartagena, como la propia María Morrás, Luis Fernández Gallardo o Ángel Gómez Moreno, apuntan que la cantidad de códices e impresos en los que se han hallado textos suyos es ingente, lo cual dificulta sistematizar dicha trasmisión ${ }^{257}$. También el famoso hispanista Alan Deyermond ha llamado la atención sobre la escasez de estudios específicos sobre Cartagena, siendo éste, según dicho estudioso, tan central en la comprensión de las «tendencias humanistas en la Castilla de la primera mitas del siglo $X V_{»}$; sostiene Deyermond que, entre otras razones, la falta de ordenación y sistematización filológica de la vasta producción de nuestro obispo dificulta la investigación sobre su pensamiento ${ }^{258}$.

Haremos aquí un somero apunte de sus obras, pero para poder adentrarse con mayor rigor en los detalles filológicos y en la transmisión textual de las mismas, invitamos vehemente a

\footnotetext{
${ }^{254}$ Morrás (2002a): 93.

${ }^{255}$ Morrás (2002a): 93.

${ }^{256}$ Marichal (1984): 22-26.

${ }^{257}$ Morrás (1991), Fernández Gallardo (2002), Gómez Moreno (1985). Para ampliar información sobre las ediciones y sobre las transmisión textual de las obras de Cartagena, véase Morrás (1991) /1996) (2002a), incluye también obras perdidas y atribuidas.

${ }^{258}$ Deyermond (1991): 323 y ss.
} 
consultar el exhaustivo trabajo de María Morrás "Repertorio de obras, mss. y documentos de Alfonso de Cartagena", en el cual nos basamos fundamentalmente a continuación ${ }^{259}$.

1) Primeramente, en su faceta como traductor, encontramos los siguientes títulos (cuyas ediciones pueden consultarse en el apartado de fuentes primarias de la bibliografía de este trabajo):

- Traducciones de Cicerón ${ }^{260}$. Como indica Villacañas, Cartagena veía las obras de Cicerón como transmisoras de enseñanzas morales y a la vez atractivas y accesibles formalmente (como un equilibrio entre filosofía y elocuencia), de ahí que pensara que eran buenas para lectores ilustrados, aunque no expertos, a los que había que transmitir estas ideas cívicas y republicanas $^{261}$. Nuestro autor contribuyó notablemente a la difusión del pensamiento del autor latino, sobre todo de su dimensión ética y política. Las obras que de él tradujo fueron:

- Libro de Tulio de Senetute, Libro de Tulio de los ofiçios (1422), las cuales realizó en una embajada en Portugal a petición de Juan Alonso de Zamora.

- De la providencia de Dios, De la clemençia, y Por Marcello (según los estudiosos, la datación oscila entre 1422 y 1427)

- La Rethórica de Tulio M. Cicerón. De invetione. (según los estudiosos, la datación oscila entre 1421 y 1433 )

- Traducciones de Séneca ${ }^{262}$. Éstas fueron muy importantes en la difusión ya no sólo de Séneca, sino también de Epicuro en Castilla, así como para la generación de adhesiones al ideal estoico.

\footnotetext{
259 Morrás (1991).

${ }^{260}$ Para ampliar información acerca de la faceta de Cartagena como traductor de Cicerón, puede verse Morrás (2002a) y (1991) y Villacañas (2005c) y (2004).

${ }^{261}$ Villacañas (2004).

262 Para ampliar información acerca de la faceta de Cartagena como traductor de Séneca, puede verse Morrás (1996), (1991) y (2002 ) Impey (1972) y Villacañas (2012b).
} 
- Tractados y Tragedias. Compilación de traducciones de textos de Séneca publicados bajo este título (entre 1430 y 1434)

- María Morrás, quien ha intentado organizar la transmisión textual de nuestro autor en un exhaustivo trabajo filológico de rastreo de fuentes, indica que entre 1428 y 1434 por encargo de Juan II, Cartagena tradujo a Séneca ${ }^{263}$ :

(...) vierte al castellano y comenta en extensas glosas los siguientes textos auténticos y apócrifos: Compilación de algunos dichos de Séneca (Tabulatio et Expositio Senecae de Lucas Manelli), Libro de la providencia de Dios, Libro de la clemencia, Libro de la providencia divinal (De constantia sapientis), Libro de las siete artes liberales (Epistola ad Lucilium, núm. LXXXVIII), Libro de la vida bienaventurada (De vita beata, De otio), Libro contra las adversidades de la fortuna (Formulae vitae honestae del pseudo S. Martín de Braga), Libro de las declamaciones (Declamationes de Séneca Anea), Libro de los amonestamientos doctrinas (De legalibus institutis), Título de la amistanza o del amigo (Fabulatio et Exposi-tio Senecae de Lucas Manelli). También se le atribuyen los Dichos de Séneca en el fecho de la cavalleria de Roma (Epitoma rei militaris de Flavio Vegecio), aunque su autoría es dudosa.

- Parece que también, a instancias de Juan Alonso de Zamora, tradujo el De casibus viromm illustrium, de Boccaccio.

2) Ya como autor encontramos las siguientes obras (cuyas ediciones pueden consultarse en el apartado de fuentes primarias de la bibliografía de este trabajo):

- Memoriale virtutum (1422 o 1425). Este Memorial de las virtudes es un compendio de la Ética aristotélica (de los libros III al VII) hecho para el príncipe heredero luso Don Duarte. En este texto Cartagena recalca la necesidad de que la dimensión ética sea una constante en la educación de los nobles, para que éstos puedan cumplir su función de servicio público. Nuestro autor realiza un recorrido por las distintas virtudes, siempre con la idea de fondo de adecuar el aristotelismo al cristianismo. Como explica Marco Campos, su idea era sistematizar una ética práctica ${ }^{264}$.

\footnotetext{
${ }^{263}$ Morrás (2002a): 93.

${ }^{264}$ Campos Souto (2004): 13.
} 
- Controversia alphonsiana, o Declinationes contra novam translationen «Ethicorum», o Declinationes super translationem Ethicorum cum Leonardo Aretino, o tamibén Liber Alphonsi episcope Burgensis contra Leonardum inuehentem conta libros Aritotelis (h. 1430 - 1432, difundido luego en 1436 durante el Concilio de Basilea), donde polemiza con Bruni respecto a la traducción latina de la Ética del Estagirita, cuya traducción canónica medieval a cargo Grosseteste, hecha a principios del siglo XIII, Bruni desdeñaba.

- Repetitio sobre la ley Gallus, o Tractatus super legem Gallus, o bien De postumis instituendis vel exheredandis. Lección pública pronunciada el 19 de julio de 1434 en Aviñón de camino hacia el Concilio de Basilea.

Durante el Concilio de Basilea (entre 1431-1438, y entre 1438 y 1445, que éste se trasladó a Ferrara) compuso los siguientes textos de corte político en defensa de ciertos privilegios del rey castellano y sobre la pertinencia e historia de la monarquía hispánica:

- De preeminentia (1434). Primero Cartagena la escribió en latín y la presentó en el Concilio de Basilea en 1434, pero tras su éxito, la redactó poco después en castellano bajo el título Discurso sobre la precedencia del rey de Castilla [o rey Católico] sobre el de Inglaterra.

- Sermo habitus in concilio Basilensis per Alphonsum decanum Compostelanum oratorem serenissimi regis Cadtelle in solempnitate sancti Thomas de Aquino. Sermón pronunciado el 6 de marzo de 1435 en Basilea.

- Sermo quem fecit reverendus pater Alfonsus electus Burgensis in sacro Concilio Basiliensis in festo Omnium Sacntorum. Sermón pronunciado el 1 de noviembre de 1435 en Basilea. 
- Allegationes super conquesta Insularum Canariae contra Portugalenses (discurso pronunciado el 27 de agosto de 1437). Cabe destacar como en sus Allegationes ya se trata el tema de la legitimidad del dominio (en este caso de Castilla sobre las Islas Canarias), tópico luego tan importante en la Segunda Escolástica y los debates en torno a la legitimidad de la conquista de América.

- Discurso del obispo de Burgos a Alberto II (1438). Presentada en 20 de noviembre en Bratislava.

- Epistula directa ad inclitum et magnificum virum dominum Petrum Fernandi de Velasco Comitem de Haro (h. 1440), en la que responde al Conde de Haro sobre la pertinencia de su deseo de profundizar en la lectura de autores paganos.

- Doudenarium (1442), en el cual responde a su amigo Pérez de Guzmán sobre doce cuestiones de diversa índole espiritual, intelectual y política.

- Qüestion fecha por el noble y magnífico señor don Íñigo López de Mendoza, Marqués de Santillana y Conde del Real, al muy sabio y noble perlado a don Alfonso de Cartagena, Obipso de Burgos. Respuesta del venerable y sabio señor don Alfonso, Obispo de Burgos, a la cuestión hecha por el magnifico señor Marqués de Santillana (1444). Conocida también como Qüestion. Esta obra muestra una intención pedagógica y moral para los nobles en torno a la idea de servicio público. Asimismo, tiene un recto tono conciliador y una reivindicación para que haya paz en la convulsa Castilla.

- Doctrinal de caballeros (h. 1444). Esta obra conforma una ética de la virtud caballeresca hidalga. Es un tratado de virtudes muy al estilo aristotélico y estoico (algo lógico si pensamos en que Cartagena tradujo a Séneca). Como explica Enver Torregroza: «La ética de la hidalguía es, entonces, una ética de las virtudes y no sólo una ética de las normas (...) Cartagena, al apelar a una ética de sustento filosófico, estaba ayudando a construir universo de valores que permitiese integrar a los conversos en la sociedad 
hispánica» ${ }^{265}$. Este texto se podría conectar con el Memorial de las virtudes, pues de ambos se puede deducir la idea de Cartagena de que el éxito militar es síntoma de excelencia moral, y ambas se vinculan a la idea de servicio público.

Estas dos últimas obras son contestaciones a Íñigo López de Mendoza y a Diego Gómez de Sandoval, Conde de Castro, respectivamente, sobre el comportamiento deseable en los caballeros, y donde exhorta a los caballeros a desempeñar un papel cívico activo como servidores públicos en pro del bien común. Ambos son tratados de educación política.

- Tractatus questionis ortolanis. Tratado que debate acerca de la superioridad del oído postura de Cartagena - o bien de la vista — postura defendida por Rodrigo Sánchez de Arévalo- (1443-1447). Su interés radica sobre todo en las reflexiones acerca de los modos de lectura en el mundo universitario castellano del siglo XV.

- Tratados de la guerra y Dichos de Quinto Curcio (1444). Se le atribuyen estos dos tratados de temática militar, pero sin la certeza de que sean de su autoría.

- Defensorium unitatis christianae, (1449). También conocido como Defensorium fidei. Es un texto nacido como obra de circunstancia a raíz del pogromo antijudío de Toledo ese mismo año y la subsiguiente redacción de los estatutos de limpieza de sangre. En dicho texto Cartagena aboga por los cristianos nuevos y la unidad de la república cristiana, pero va más allá de eso y acaba conformando este tratado un lúcido ejercicio jurídico y filosófico de teología política, así como sentando las bases de un proyecto de convivencia para Castilla marcado por una ratio política de la inclusión y por la articulación entre elementos religiosos y republicanos. Dicho tratado encarna en nuestra opinión una de las cumbres de lo que hemos venido denominando pensamiento político converso. Del Defensorium nos ocuparemos en profundidad en el siguiente capítulo.

- Pastoral sobre las reliquias de Santa Juliana. Sermón pronunciado el 16 de septiembre de 1453

${ }^{265}$ Torregroza (2010): 181. 
- Oracional de Fernán Pérez de Guzmán (1454), esta obra es un libro de rezos que redactó Cartagena para su amigo Fernán Pérez de Guzmán, donde aparece el Cartagena más rigorístico y se aúna ética y espiritualidad.

- Apología sobre el salmo «Judica me Deus» (1456), trabajo éste también de ortodoxia religiosa.

- Glosa a San Juan Crisóstomo. Glosa escrita a petición de Juan II (h. 1456 ?)

- Anacephaleosis nempe Regum Hispanorum, Romanorum Imperatorum, Summorum Pontificum necnon Regum Francorum o Rerum in Hispania gestarum Chronicon (1456). Éste es el último texto que elaboró nuestro autor, y es una obra de cariz histórico en la que se legitima la visión mítica, providencialista y goticista de la monarquía hispánica. Como indica Menéndez Pelayo, la Anacephaleosis es un compendio de un escrito mayor que dedicó Cartagena al rey Juan II y que abordaba la historia de la monarquía hispánica desde el godo Atanarico hasta el propio años 1456; habla de dicho compendio citándolo bajo el título de Genealogía de los reyes de España, Diego Rodríguez de Almela en su Valerio de las historias ${ }^{266}$.

Se conserva también diversa correspondencia del autor con otros intelectuales del momento y se le han atribuido (aunque sin demostrar), asimismo, otros tratados y diversos poemas y cantares dispersos en distintos cancioneros castellanos del momento ${ }^{267}$.

\subsection{Controversias respecto a la figura intelectual de Cartagena.}

Ya el hecho de sí Alonso de Cartagena fue o no fue un humanista ha sido un punto polémico para la literatura especializada en el autor, sobre todo la proveniente de la filología. Para asomarnos a esta polémica, antes que nada, hay que tener en cuenta la propia comprensión que

\footnotetext{
${ }^{266}$ Menéndez Pelayo (1952). Para más información puede verse Tate (1970).

${ }^{267}$ Para más información al respecto véase Morrás (1991).
} 
del término «humanista» se tiene en el ámbito de la filología — que es desde donde más se ha estudiado a Cartagena-, para la cual el humanismo es una corriente intelectual sobre todo filológica, o sea, relacionada con los llamados studia humanitatis, en una interpretación en la senda abierta por Kristeller ${ }^{268}$. Sin embargo, para nosotros el término humanismo tiene también una indudable vis política y filosófica (aunque, como ya expusimos en el capítulo primero de este trabajo, preferimos no emplear dicho término al hablar de la filosofía política castellana del siglo $\mathrm{XV}$, dado que los académicos que lo hacen lo emplean contraponiéndolo con la escolástica). Desde esta óptica política es desde la que partimos y desde la que queremos abordar aquí el pensamiento de Cartagena.

Para Manuel Alonso — editor del Defensorium —, Guillermo Verdín-Díaz — traductor del mismo - o los estudiosos del pensamiento político de Cartagena, José Luis Fernández Gallardo, Enver Torregroza, Fernando Miguel Pérez Herranz, José Luis Villacañas —para quien don Alonso es comparable a Bruni-, u Ottavio di Camillo, hay que comprender a Cartagena como figura de transición epocal, algo con lo que coincidimos plenamente. Escribirá el profesor italiano di Camillo, primer defensor de Cartagena (frente a la común opinión de asumirlo como un rigorista religioso sin más, opinión fruto de no abordar su obra en profundidad ni contextualizarla): «Ni es un teólogo escolástico opuesto a la retórica humanista, ni es un bárbaro como se la ha querido catalogar, incapaz de comprender los nuevos ideales humanistas (...) En Cartagena la vemos [la retórica] como una ciencia que completa a la filosofía, puesto que, en ella, la forma y el contenido son inseparables. En realidad, el contenido precede a la forma, reafirmándose así en la importancia de la res sobre el verbum» ${ }^{269}$. De hecho, dicho estudioso entenderá a Cartagena como uno de los mejores exponentes de la recuperación del pensamiento cívico de la Antigüedad.

No pasemos por alto que nuestro obispo tradujo a Séneca y Cicerón, piezas clave en la recuperación de los valores del republicanismo clásico. Además, Cartagena estuvo en estrecho contacto y debatió con sus contemporáneos del humanismo italiano. La diferencia con éstos es que Cartagena no renegó nunca de la escolástica ni del legado que el pensamiento medieval

\footnotetext{
${ }^{268}$ Kristeller (1993).

${ }^{269}$ Di Camillo (1976): 53.
} 
había supuesto en la transmisión de estos valores republicanos y del iusnaturalismo, así como no dudó de las posibilidades que abría la imbricación de estos valores cívicos con el cristianismo. Para Cartagena, figuras como Tomás de Aquino o Masilio de Padua eran también maestros, y por ello no entendía el Renacimiento como un momento de ruptura con lo previo. Tampoco para Cartagena —en línea con lo que expusimos en los capítulos previos de esta tesis como inherente al pensamiento político converso del XV castellano- eran cuestionables la dimensión escatológica de la filosofía de la historia, ni la institución monarquía, pero esto lo veremos más adelante. Creemos que hay que entender a Cartagena como una figura que encarnó un cruce de caminos, tanto epocal como cultural, en lo que a historia intelectual se refiere. Dice sobre él Enver Torregroza $^{270}$ :

El "humanismo" de Cartagena es también la defensa (al interior de la Ciudad Fiel) cristiana de la filosofía clásica, en particular de la filosofía política clásica (...) Cartagena fue filósofo en sentido tradicional, por helenizante y por lector de Aristóteles, pues era comentador y transformador de sus ideas; también fue filósofo en el sentido cristiano, por teólogo, exegeta y defensor de la fe, y filósofo en el sentido judío, por riguroso amante de los textos, cuidadoso interprete de la ley y hábil hombre de letras, que navega con comodidad entre las exigencias de la razón y las del alma.

Sin embargo, otros estudiosos, sobre todo, insistimos, en el ámbito de la Filología, son renuentes a verlo como una figura propia del Renacimiento, sobre todo por su forma de traducir. Recordemos la conocida polémica que tuvo con Bruni en torno a la traducción de la Ética de Aristóteles, pues Bruni rechazaba la traducción canónica medieval de Robert Grosseteste ${ }^{271}$. Esta polémica le acarreó a Cartagena una injusta mala fama que aún pervive y provocó que fuese incomprendido y que se generalizasen a priori juicios sobre su todo pensamiento. No cabe duda que Cartagena no ha sido comprendido en toda su profundidad, es más, ha sido malinterpretado. Como sostiene con ironía Rafael Herrera: «Cartagena perdió la batalla en todos los frentes. En la historia de su recepción académica ha triunfado mayoritariamente la versión que interpreta a Bruni como representante de un proyecto humanista educado (por tanto, positivamente moderno

\footnotetext{
${ }^{270}$ Torregroza (2010):179-180.

${ }^{271}$ Para ampliar información sobre esta afamada polémica, pueden verse, por ejemplo: Morrás (2002), González y Saquero (2000), Villacañas (2012b), o Herrera (2016).
} 
y progresista) y a Cartagena como un recalcitrante sumo sacerdote de la escolástica (por lo tanto, anti-moderno y reaccionario)»» ${ }^{272}$.

Comparte nuestra postura Miguel Pérez Herranz quien firma que esta polémica ha hecho que se lo vea como un conservador y un pensador cerrado a las fuentes clásicas, cuando, en el fondo lo que defendía Cartagena era que las virtudes morales que describe la obra del griego eran compatibles con las virtudes teologales, y sugería que el estudio de la moral de la Antigüedad podía servir como camino de acercamiento al cristianismo, sin embargo, Bruni pretendía escindir ambos campos, entendiendo la filosofía moral como algo secular. Todo lo anterior reverbera tras la polémica en torno a la traducción de la Ética del Estagirita, una polémica que en realidad iba mucho más allá de lo meramente filológico. A diferencia de Cartagena, Bruni rechazaba las traducciones medievales de dicha obra aristotélica porque quería romper con la ligazón medieval tomista entre filosofía moral y el cristianismo. Además, Cartagena no defendía una ruptura con la historia para reafirmar el proyecto renacentista, como, sin embargo, sí hacía Bruni (ya nos detuvimos en esto en el Capítulo 1). Otro factor de conflicto entre ambos fue que Cartagena temía que la forma de traducir de estos humanistas italianos antepusiese la elocuencia al saber científico, esto es, para Cartagena la traducción es un instrumento, un complemento al texto original, pero el afán estético al realizar la traducción no puede dificultar la comprensión (para la cual, además los comentarios y glosas son una ayuda). Como indicara otro intelectual castellano del momento, Pedro de Osma (que fue un gran conocedor de Aristóteles y profesor en la Universidad de Salamanca) la traducción no podía suplir la vetus interpres, lo importante es el rigor de la expresión y no la verbosidad ${ }^{273}$.

Resulta paradójico que la postura de Cartagena en dicho debate trascendiese como un rechazo a los clásicos de la Antigüedad, algo incomprensible cuando nuestro autor contribuyó notablemente a su traducción y a la difusión de su pensamiento moral y político. El hecho de que para él era deseable compatibilizar la filosofía de autores como Aristóteles, Cicerón o Séneca con la doctrina cristiana no es en absoluto razón para afirmar, incorrecta y sesgadamente, que

\footnotetext{
${ }^{272}$ Herrera (2016): 109. La traducción es nuestra, el texto original es: "Cartagena lost the battle in all fronts. In the history of their academic reception, has mainly triumphed the interpretative version made of Bruni by the representative of an educated humanist project (thus, positively modern and progressive) and of Cartagena that of a recalcitrant high priest of scholastics (hence, anti-modern and reactionary)".

${ }^{273}$ Tomo esta información de Pérez Herranz (2016).
} 
Cartagena menospreció el pensamiento clásico. Él mismo expresó en el prólogo a su traducción de De los ofiçios: «Ca non solamente nos devemos aprovechar de los libros de nuestros doctores, mas aun las buenas doctrinas de los de fuera de la iglesia; si consentáneas y concordes son a la razón natural e ayudan a la buena e católica ordenança de bevir, acarrearlas deuemos por que de todas partes sean nuestros actos çercados del muro de la virtud» ${ }^{274}$. Acierta José Luis Villacañas con esta reflexión a la que nos sumamos: «Este sentido integral de la retórica, como síntesis de la elocuencia con la sabiduría, describe con precisión la posición de Cicerón y que Cartagena era más coherente con el espíritu cívico del romano al dar una versión castellana, que Bruni al mantener el elegante latín» ${ }^{275}$.

El estudioso Rafael Herrera, en un artículo que analiza con originalidad la afamada controversia Bruni-Cartagena, entiende que tal polémica en realidad entraña toda una pugna entre dos modelos de Modernidad (al respeto, recordemos, nos referimos en el Capítulo 1 de este trabajo) $)^{276}$.

Se ha criticado de Cartagena, asimismo, su ambivalente actitud sobre la conveniencia de promover la lectura de textos clásicos paganos dado su potencial riesgo a desviar de la ortodoxia. Apunta Georgina Olivetto al respecto que la eclosión de nuevos lectores, por ejemplo nobles que se sumaban al 'armas y letras' y se acercaban a textos paganos, modificó la actitud de Cartagena ante los clásicos, tornándolo receloso. Señala también la estudiosa cómo lo advierte Cartagena en el prólogo del Libro I de la providencia: «E así mesmo donde sentí, perdóneme Séneca, alguna conclusión que contradixiese a los sanctos doctores, contradíxela luego, porque non le

\footnotetext{
${ }^{274}$ Cartagena, lo tomo de edición de Morrás (1996).

${ }^{275}$ Villacañas (2005c): 13.

${ }^{276}$ Dada su pertinencia, conviene repetir aquí la interesante reflexión de Rafael Herrera que ya reprodujimos en el Capítulo 1: «El fracaso de Cartagena nos alcanza hasta hoy (...) Paradójicamente, será Castilla, y el hispanismo sistémico, los que fomentarán la modernidad imperial/colonial de Bruni. El primer lugar donde Cartagena perdió la batalla fue en España, siendo él mismo testigo y víctima. Esta derrota se extendió al resto de Europa hasta la actualidad (...) Hubo una Modernidad perdida que sobrevivió a pesar de la derrota, cuyo origen se remonta a los conversos hispanos del siglo XV (...) En el debate Bruni y Cartagena descubrimos las raíces genealógicas del proceso en fragmentos significativos del debate, como el de la excentricidad de Hispania frente a la centralidad de Italia (...) En el texto de Bruni podemos ver perfectamente cómo, en el juego binario triunfal de la Modernidad unidireccional, ésta es identificada con la civilización. Esta es la razón por la cual la polémica tiene el carácter de un arquetipo de la Modernidad, pues en ella hay una confrontación entre la Modernidad unidireccional, victoriosa e imperial del hombre blanco - el europeo-y la Modernidad plural, derrotada y cosmopolita del mestizo — del europeo converso- - La Modernidad unidireccional se configurará progresivamente a través de exclusiones binarias, desde lo humano hasta lo geográfico» Herrera (2016): 101, 102, 105, 116.
} 
dexásemos con ella pasar e el que lo leyese non fuese engañado, ca en tanto es de dar fauor a las escripturas de los gentiles, en quanto de la cathólica verdat non desvían» ${ }^{277}$. Al respecto, la profesora María Morrás expondrá: «La intuición por parte del obispo de Burgos de que el énfasis en la universalidad del pensamiento ético llevaría al laicismo en la cultura, algo que ya vislumbraba en 1422, le hizo rectificar el modo en que acometía la divulgación de los textos latinos» $^{278}$.

Autores como Francisco Rico lo han visto incluso bajo el manto de la «barbarie», que según este hispanista es casi ubicua en Castilla hasta la llegada de Nebrija (literalmente así se titula unos de sus libros Nebrija frente a los bárbaros), postura con la que, evidentemente, no $\operatorname{concordamos}^{279}$. Karl Bluher, por su parte, reconoce la importancia de la labor de traductor de Séneca de Cartagena, pero piensa que sus traducciones tienen un espíritu aún medieval; en la misma dirección están Mario Penna, Alejandro Coroleu o N. H. Lawrence, para el cual Cartagena ha de seguir la senda rigorística de la tradición patrística porque su condición de converso y de hombre de Estado le exigen un celo de la ortodoxia «que luego torna muy ecléctica su posición frente al humanismo» ${ }^{280}$. También posee sobre él una opinión que lo liga a la más estricta ortodoxia Anxo Pena, la cual explica por el apoyo que hace Cartagena reiteradamente en su obra de la lucha contra la herejía, pues, según el estudioso, pese a que defienda a los conversos, apoya la persecución y expulsión de musulmanes y judíos ${ }^{281}$. Para Karl Kohut, el problema está —al igual que, según él, sucede con Alonso de Madrigal, 'el Tostado'en el conflicto suscitado por el hecho de conocer las letras paganas y su condición de religioso, una situación compleja que a veces la hace vacilar entre posturas opuestas ${ }^{282}$.

Respetamos estas opiniones, pero no las compartimos. Según nuestra opinión, Cartagena es un máximo exponente del pensamiento político converso que hemos descrito en los capítulos previos, y cumple con las característica expuesta acerca del mismo. El que Cartagena siguiese un formato escolástico, no renegase de su herencia medieval o fuese defensor del catolicismo, no

${ }^{277}$ Olivetto (2010): 240. [Referencia de la cita de Cartagena de Libro I de la providencia, tomado de la nota 35 : BNM 6962, f. 5v].

${ }^{278}$ Olivetto (2010): 39 [nota 33].

${ }^{279}$ Rico (1978).

${ }^{280}$ Penna (1959), Coroleu (1998), Lawrence (1979) (1990): 225.

${ }^{281}$ Pena (2008).

${ }^{282}$ Kohut (1982). 
puede llevarnos al juicio fácil de que esto le hacía ser un reaccionario de la ortodoxia y le impedía incorporar elementos innovadores en su pensamiento. Todo lo contrario: la grandeza de Cartagena es precisamente el haber aunado de forma cabal en su pensamiento todas estas variables: el mensaje cristiano paulino, el tomismo, la filosofía de la historia escatológica, el prereformismo religioso, el profetismo hebreo, el iusnaturalismo, a los autores clásicos que son base teórica del pensamiento republicano (en cuanto al vivere civile, en cuanto a las ideas de igualdad, libertad e inclusión y en cuanto al cuestión del origen y limitación de la autoridad), el ideal de modelo de gobierno mixto, el conciliarismo, el organicismo místico y monárquico, la tradición jurídica Alfonsina castellana, el racionalismo árabo-semítico peninsular, o el goticismo. Sobre todo la característica más destacable, a nuestro entender de Cartagena, es el haber articulado la idea de comunidad política con la de communitas cristiana, la idea de república cívica con la de república cristiana, la teleología cívica con la teleología de la salvación, esto es, el haber asumido elementos religiosos como garantes de ciudadanía, y viceversa, el haber asumido que el desarrollo de los valores republicanos contribuían a ser un buen cristiano y a la salvación. No decimos que sea el primer — ni el último - pensador en hacerlo pero hay que resaltar el que lo hizo y el cómo.

Sería interesante, en cualquier caso, ver lo que sus coetáneos pensaban de él, por ejemplo Juan de Lucena, otro importante e interesantísimo intelectual converso, toma a Cartagena como uno de los personajes de su diálogo Libro de vita beata reconociendo en él un maestro para su generación y su faceta de intelectual comprometido, dirá Lucena: «Para ella [Castilla] naciste, no para ti solamente: Tú de cavallería, tú de re pública, de fe cristiana escreviste $[\ldots ..]{ }^{283}$. Asimismo, Fernán Pérez de Guzmán le hace un admirado retrato en sus Generaciones y semblanzas, al igual que Fernando del Pulgar en su Claros varones de Castilla o el Marqués de Santillana en su Qüestión sobre el fecho de cavallería ${ }^{284}$. Cartagena formó en torno a él un potente círculo intelectual - la base del pensamiento político converso - También pensadores extranjeros como Decembrio, Piccolomini o Bruni alabaron su magnitud intelectual.; como expresa con cierto humor Torregroza: «Es necesario hablar no sólo de la influencia del humanismo renacentista

\footnotetext{
${ }^{283}$ Lucena (2014, edición de Jerónimo Miguel).

${ }^{284}$ El texto de Fernán Pérez de Guzmán aparece en Foulché (1912-1915): 677, el de Fernando del Pulgar en Tate, R. (1985): 140-42, respecto al texto de Santillana, lo encontramos en Gómez Moreno (1985): 335-363.
} 
italiano en Cartagena, sino también de la influencia del racionalismo converso de Cartagena en el humanismo renacentista italiano» ${ }^{285}$.

Es cierto que Cartagena asociaba como deber de la monarquía castellana la lucha contra la herejía para consolidar la unidad religiosa, pero no entendemos que esto lo hiciera, como podría parecer a simple vista, con una vocación de exclusión sino en la búsqueda de la creación de un nuevo pueblo, de una base comunitaria sólida, veremos esto más adelante al analizar la ratio política que subyace a su Defensoruim unitatis chistianae.

Deberíamos además contextualizar a Cartagena también como un estadista que ha de cumplir en lo formal con ciertas posturas casi propagandísticas en algunos textos, más por añadidura si eran encargos y obras de circunstancia. Obviar la dimensión propagandística de muchos de los textos del Renacimiento y el papel de los letrados como intelectuales orgánicos sería un tremendo anacronismo y una falta de conocimiento del periodo. Más allá de las alabanzas y loas que se hacen en las dedicatorias de estos textos, o incluso de las conclusiones alcanzadas y la postura "vencedora" cuando se trata de un diálogo, hay que leer entre líneas y ver en profundidad las posturas que el propio texto está mostrando y queriendo difundir (aunque esto fuese explicitado en un personaje antagonista en un diálogo, por ejemplo). Esto explica el que en autores como Cartagena podamos incluso hallar aparentes contradicciones entre sus propios textos. Nuestro burgalés es sin lugar a dudas un perfil rico y complicado, poliédrico, con sus tornasoles, los cuales creo que sería demasiado severo juzgar como contradicciones e implicaría no comprender los códigos que operaban en el siglo XV. El que encontremos en Alonso de Cartagena ciertas ambigüedades u oscilaciones es algo propio de momentos de transición o del simple hecho de que muchos de los textos estaban patrocinados por la corte, eran textos propagandísticos inherentes a su labor como hombre de Estado y de Iglesia. Hay que leer también entre líneas a Cartagena, pues bajo su formato escolástico y pese a su aparente ortodoxia reverberan enfoques mucho más avanzados de lo que ha querido verse. Dicho de un modo coloquial, si se nos permite, se podría aseverar - parafraseando lo que Guido Cappeli dice refiriéndose a Diego de Valera y aplicándolo a Cartagena— que éste «hace cosas humanistas»

\footnotetext{
${ }^{285}$ Torregroza (2010): 17.
} 
con materiales más bien tradicionales, mostrando una sensibilidad integrada con las tendencias del momento ${ }^{286}$.

Cartagena en su uso de fuentes se enraíza en textos más bien tradicionales, pero hace un uso consciente de esta tradición atravesada por el concepto cívico de servicio público y por un patente aristotelismo Si bien Cartagena conoce y emplea también materiales de sus coetáneos, su cuerpo de fuentes viene sobre todo de materiales teológicos - ya sean bíblicos, veterotestamentarios básicamente, de la Patrística, del tomismo o conciliares-, de la tradición jurídica (tanto del derecho común como del derecho canónico), de la filosofía antigua (principalmente Aristóteles, Cicerón o Séneca), o de la Historia de España; los pilares de su elaboración doctrinal son los autores antiguos y la filosofía moral, pero esto no implica en absoluto un pensamiento político retrógrado.

Al igual que el hecho de que sus formas argumentativas sean escolásticas no implica que sus contenidos fueran "conservadores" (si se nos permite la expresión), sobre todo en el ámbito del pensamiento político, donde la presencia de la patrística se equilibra con textos clásicos de raigambre jurídica y filosófica. Es cierto que conjuga ideas republicanas con su apoyo acérrimo al rey (pensemos al respecto que su ideal es un modelo de gobierno mixto, y que, como hemos venido sosteniendo nos atenemos a una comprensión no restrictiva del concepto de republicanismo no caracterizado únicamente por la cuestión 'monarquía sí o 'monarquía no'). Es acertado hacer notar que desactiva el estigma de origen carnal como inhibidor de ciudadanía y al mismo tiempo defiende los privilegios estamentales; es verdad también que promueve la inclusión de los conversos y justifica la guerra justa contra la herejía, pero opinamos que para no introyectar estas misturas como paradojas, debemos tener la suficiente amplitud de miras y tratar de comprender un contexto intelectual como el del siglo XV, castellano, algo que posibilita el Capítulo 2 de este trabajo.

De nuevo con la experta en Cartagena María Morrás, en un texto ahora sobre lo adecuado o no de catalogar a Cartagena como humanista, la estudiosa apunta ${ }^{287}$ :

\footnotetext{
${ }^{286}$ Cappelli (2014): 8.

${ }^{287}$ Morrás (1995): 342-343.
} 
$\mathrm{Y}$ en efecto, la paradoja se disuelve en gran medida cuando se consideran la naturaleza y los destinatarios, muy diversos, de sus obras. (...) Cartagena ejerce la persona retórica de preceptor público de la nobleza, grupo doblemente sometido a su auctoritas, por laico y por lego, a la que reconvierte en su calidad pública de pastor de la Iglesia y de scolasticus vir. Las cartas a Decembrio, en cambio, eran otra cosa: pertenecían al ámbito privado y fueron escritas a un ilustre erudito italiano al que admiraba, pero en el que vio un colega al que tratar de tú a tú y con el que podía compartir curiosidades y consultas (...) En consecuencia, concibió su obra escrita a modo de prolongación de su actividad profesional como letrado, bien en su calidad de burócrata oficial - como dictator profesional—, impulsado por intereses sociales y políticos, bien en su calidad de scolasticus vir, esto es, de erudito profesional, ya fuera al servicio del estamento caballeresco o espoleado por sus particulares curiosidades intelectuales.

Sin embargo, Morrás ve en Cartagena también una actitud «comprometida, militante» ${ }^{288}$. Y llena de pragmatismo, añadimos, pues nuestro burgalés no abandonaría nunca en sus textos un deje pedagógico y el anhelo de elevar la calidad moral, intelectual y el sentido de servicio público para el bien común (en sintonía con la filosofía práctica aristotélica), de las capas dirigentes castellanas.

Además, su celo de la ortodoxia cristiana no hace que renuncie a su herencia metodológica tomista, al bagaje del racionalismo arabo-semítico y a su constante defensa del lenguaje de la razón como algo universal y superior a cualquier discurso oficial que quisiera imponerse. Características éstas que tan importantes resultaron en el desarrollo de la figura del intelectual medieval que posibilita la génesis del pensamiento moderno. A este respecto es muy interesante el trabajo de Alain de Libera, de quien tomo el comentario ${ }^{289}$. Tampoco renuncia Cartagena a su conocimiento de autores clásicos seculares y a su conocimiento jurídico no canónico (no olvidemos su formación como doctor en Derecho Civil). Todas estas herencias las hibrida con su pensamiento doctrinal, y esto es su valor añadido, pues esto le permite generar un singular pensamiento político y una sugerente teología política.

Es interesante, asimismo, como hace notar el experto Luis Fernández Gallardo, la forma de abordar el saber histórico de Cartagena en algunas obras como el Defensorium, en el que se

\footnotetext{
${ }^{288}$ Morrás (1995): 344.

${ }^{289}$ Libera, Alain de: Pensar en la Edad Media, 2000, Anthropos, Barcelona.
} 
hace un uso historicista del Derecho Común. Este nuevo enfoque fue fruto probablemente de su contacto en Basilea con las innovaciones al respecto de los historiadores italianos. De todos modos, este enfoque no es constante en su trabajo, y no elimina la visión escatológica de la historia de Cartagena. Como, asimismo explica Fernández Gallardo: «Y sin embargo, esta apertura a los nuevos valores renacientes no cuajará en un replanteamiento y renovación del quehacer historial (...) no sólo se mantendría apegado a las formas historiográficas más añejas y tradicionales, sino que ya al final de su vida volvería a la concepción de la historia como colección de casos ejemplares» ${ }^{290}$.

Quizá la propia indefinición de la academia acerca de dónde situar a Cartagena (afán de clasificarlo, por otro lado, que no vemos necesario al considerarlo nosotros, como hemos dicho, como una figura de transición), de lo que más es reflejo es del desconocimiento acerca del autor. Desconocimiento por varias razones:

1) Porque Cartagena quedó casi confinado al olvido ya desde el siglo XVI, dado que para el pensamiento oficial castellano, su naturaleza conversa y su defensa de este colectivo generó suspicacias sobre él. Precisamente por su apoyo a los conversos y su apuesta por una política inclusiva, por su defensa, como civilista que era, al apego a la legalidad frente a la arbitrariedad en el uso de la autoridad, tal vez comenzó a resultar un agente incómodo para la justificación del discurso oficial, cuya ratio política quedaba ligada a la dominación y la exclusión.

2) Porque dicho desconocimiento sobre nuestro autor puede venir de un desinterés que esconda, tal vez, como sugiere Rafael Herrera, un rechazo a lo que representa Cartagena: una modernidad más «plural» (eso es, en la que cupiese la impronta cultural árabosemítica), y una concepción más flexible del humanismo al asumirlo menos encorsetado por violencias epistémicas que, en el fondo, escondían una pretensión de superioridad cultural contra una Castilla demasiado «mestiza» y que, además, no negaba la herencia medieval, como sí lo hacía el discurso renacentista italiano para consolidar una utopía de la Modernidad ex novo ${ }^{291}$. Fernando Miguel Pérez Herranz diferencia la posición de lo

\footnotetext{
${ }^{290}$ Fernández Gallardo (2002): 278.

${ }^{291}$ Herrera (2016): 109.
} 
que él llama humanismo hispano-converso frente a la de lo que llama humanismo italianizante, cuyo criterio epistemológico, dice, se encuentra voluntariamente reducido a los textos de una segmento limitado de la Roma antigua ${ }^{292}$. Ninguno es mejor que el otro, claro está, pero ambas implementaciones han de tenerse en cuenta, como vimos con detalle en el Capítulo 1. Además, en el ámbito castellano la incorporación de valores republicanos propios del XV, no se contrapuso ni con el eschaton, ni con el apoyo a la monarquía, algo en lo que la historia dominante de la filosofía política parece no reparar.

3) Porque tal desconocimiento es reflejo también del escaso interés que desde la historia de la filosofía política y la historia intelectual se ha hecho al pensamiento político hispano e hispánico en general, y del pensamiento político del XV castellano en particular, cuestión ésta ya vista con detalle en el Capítulo 1.

Cartagena es epítome del pensamiento político converso del que hemos venido hablando: no tratar de comprender las características propias y particulares de nuestro personaje, es no tratar de comprender el pensamiento político converso castellano del siglo XV y sus especificidades y seguir invisibilizándolo.

El acceso al pensamiento de Cartagena fue mermando y quedó reducido a ambientes intelectuales muy limitados y heterodoxos, sin embargo, su impronta intelectual —así como la del proyecto ético y político de los pensadores conversos en general — sí influyó enormemente en la conformación del llamado pensamiento hispánico. Perduró, y lo encontramos por ejemplo en la revolución comunera, en el reformismo religioso por ejemplo de los alumbrados y preerasmistas, o en la Segunda Escolástica. En esto nos detendremos al final del siguiente capítulo y en las conclusiones de este trabajo.

${ }^{292}$ Fernández Herranz (2016): 285. 


\subsection{Introducción a su pensamiento político. Acerca de su noción de monarquía y de su postura ante la cuestión del origen de la autoridad.}

Pese a que Cartagena no escribió ningún tratado sobre teoría política como tal, la reflexión y preocupación política es trasversal a todos sus textos, aunque, como hemos mencionado, no siempre homogénea, de ahí que su pensamiento político no sea fácil de asir y sistematizar. Intentaremos en este apartado siguiente introducir someramente su pensamiento político. Nos detendremos sobre todo aquí en su idea de servicio público y en su noción de la monarquía. Será en el Capítulo 4 donde nos centraremos en su teología política - ya que esto es lo que más nos concierne en este trabajo y donde queremos hacer notar la originalidad y el aporte de Cartagena al hibridar elementos de corte republicanos con elementos religiosos - y donde subrayaremos su loable y crucial labor en el intento de dignificar la condición conversa, de combatir el racismo a la que los cristianos nuevos eran sometidos y de conformar una racionalidad política inclusiva más allá de esencialismos de origen, esto es, de conformar una comunidad cristiana que fuera además comunidad política. Supo, además, fortalecer la identidad conversa dándole una sólida consistencia y justificación teológica.

Antes de nada hay que reiterar el sugerente perfil del pensamiento de Cartagena, en el que confluyen $-\mathrm{y}$ conviven en recíproco enriquecimiento- diversas traiciones intelectuales, teológicas y culturales. Esto le da un factura única a su pensamiento, atravesado a la vez por la escolástica, el derecho romano común y el derecho canónico, la escuela moral aristotélica, la huella de Cicerón y de Séneca, el tomismo, la recuperación del republicanismo clásico, el biblismo y profetismo hebreos, el misticismo organicista paulino y los elementos propiamente hispánicos. Capta bien esta naturaleza de Cartagena el siguiente retrato que de él hace el profesor Enver Torregroza ${ }^{293}$ :

Por ello, la filosofía de Cartagena representa emblemáticamente la transición, a través de su racionalismo teológico converso, de la filosofía política maimonideana de inspiración farabiana, a la filosofía aristotélica tomista, donde la filosofía política clásica, es el camino que se practica para lograr la felicidad en este mundo y el Evangelio es el camino que se practica en este mundo para la salvación en el más allá. En este de sentido, la búsqueda de la felicidad humana en este mundo, no implica por ello la renuncia a la

${ }^{293}$ Torregroza (2010): 179-180. 
búsqueda de la felicidad en el otro; la política no implica el rechazo de la religión: antes bien, la religión implica la política, la funda (...)

Luis Fernández Gallardo, experto en el burgalés, indica que el pensamiento político de éste no es sistemático sino flexible, algo que puede parecernos hoy incluso contradictorio, pero que, según Fernández Gallardo «obedece no tanto a una evolución en las convicciones del autor - por otra parte lógica, dado que su quehacer literario se extiende a lo largo de tres largos decenios cuajados de experiencias decisivas-, cuanto al carácter y naturaleza de cada una de sus obras» ${ }^{294}$. Esto es, están presentes también cuestiones mucho más pragmáticas como son las limitaciones de su propia peripecia personal de Cartagena y el hecho de la función y el destinatario de cada uno de sus textos, y está la circunstancia de que Cartagena, además de obispo, era consejero del rey Juan II.

El estudioso referido, destaca ante todo las ideas más tradicionales del autor que nos ocupa, como su apoyo al monarca, visto como un vicario de Cristo que ha de ser cabeza dirigente y acometer la guerra justa contra la herejía, o su defensa del honor estamental. Pero también reconoce Fernández Gallardo rasgos más típicamente renacentistas que detectamos en su pensamiento, así su defensa de la idea de servicio público vinculada con el ideal republicano de desarrollo de la virtud moral a través de la vita activa a través de la participación en el vivere civile, su patriotismo o su uso de la propia experiencia como herramienta analítica y expresiva ${ }^{295}$. Incide también en la pulsión secularizadora de Cartagena en cuanto a que ve la actividad política como inmanente, esto es, que atañe sólo a la naturaleza humana en su dimensión social consecuencia del intenso naturalismo que toma de la doctrina aristotélica- y como autónoma, es decir con principios morales propios ${ }^{296}$.

Coincidimos con Fernández Gallardo en la cuestión de la adhesión de Cartagena al ethos de la acción aristotélico. Sin embargo nos distanciamos de Fernández Gallardo respecto a cómo éste ve en Cartagena el secularismo. Es cierto que Cartagena es consciente de las ventajas de un secularismo en el ejercicio del poder, en el sentido de no injerencia de la Iglesia en el gobierno

\footnotetext{
${ }^{294}$ Fernández Gallardo (2002): 322.

295 Fernández Gallardo (2007): 322 y ss.

${ }^{296}$ Fernández Gallardo (2002): 333.
} 
temporal (en esto estamos de acuerdo con Fernández Gallardo), pero no pensamos, como dice este estudioso, que Cartagena entienda la actividad política como inmanente y concerniente sólo al hombre en su dimensión social y no en la espiritual debido a un naturalismo de corte aristotélico. Según nuestro criterio, Cartagena sí toma elementos cívicos aristotélicos, pero los articula con el cristianismo. No pensamos que para Cartagena la política sea un ámbito autorreferencial en cuanto a los principios morales. Se da una ligazón de la idea de comunidad cristiana con la de comunidad política y se hace confluir la teleología de la salvación con la de la cuidad; esto lo veremos al analizar el Defensorium unitatos christianae en el siguiente capítulo. No es que nuestro obispo crea que la Iglesia ha de intervenir en la ejecución del poder temporal, pues ahí Cartagena sí marca distancias y es consciente de las ventajas del secularismo en este sentido, pero lo que queremos señalar es que en Cartagena sí hay una articulación entre la cuestión religiosa y el acceso a lo político, por ejemplo al afirmar que elementos religiosos como el bautismo permiten un acceso a la ciudadanía, es decir, que el formar comunidad religiosa pueblo cristiano - implicará formar comunidad política. Por otra parte, además, tampoco Cartagena tiene un enfoque secular ni lo referente a la filosofía de la historia, ni lo referente al enfoque organicista y providencialista del monarca.

La labor de Cartagena en la difusión de la filosofía moral de los clásicos fue fundamental, tanto en su labor como traductor de Cicerón y de Séneca como en la forma en que el aristotelismo, el civismo ciceroniano, el estoicismo y el derecho romano están presentes trasversalmente en sus textos, todos articulados con el cristianismo. Las traducciones y comentarios que realizó Cartagena de la obra de Séneca gozaron de una enorme difusión; su Libro de la vida bienaventurada, que incluye versiones del De vita beata y el De otio del autor latino, tiene gran importancia, además de por su labor de transmisión y afianzamiento del pensamiento de Séneca, por su contribución en la rehabilitación de la figura de Epicuro en Castilla. Nuestro obispo refleja una clara sintonía con el ideario de Séneca y el perfecto engranaje de éste con la ortodoxia cristiana. A su vez, tiene una actitud receptiva hacia Epicuro. Obviamente, reprobará todo lo concerniente a la filosofía natural del griego (se desliga de ello y se centra solamente en su filosofía moral), pero verá las bondades de su ideal ético, basado éste en el autoconocimiento y la contención (punto del epicureísmo fácilmente asimilable por el cristianismo). Cartagena está interesado en estoicismo, que también anhela un ideal de virtud 
obtenida a través de la honestidad y el quehacer social, una búsqueda de la verdad en el desempeño del cometido social. En relación a las posturas materialistas neoepicúreas, llama la atención su opinión bastante comprensiva acerca de quienes niegan la Providencia: no lo hacen porque sean unos heréticos o unos desnaturalizados sino porque $-\mathrm{y}$ Cartagena parece entender su lógica - han de enfrentar un mundo lleno de absurdos e injusticias. Al igual que otros textos de raigambre ortodoxa, su traducción del Libro de la vida bienaventurada fue, paradójicamente, uno los mejores difusores de las tesis materialistas que se esmeraba en refutar.

De Cicerón tomará Cartagena sus valores republicanos acerca del alcance de la virtud a través del desarrollo de la vita activa a través de la participación en el vivera civile en pro del bien común. Y, como expone Villacañas comparte con el autor romano la necesidad de la existencia de una sabiduría civil, destinada a realizar la politia, la buena ordenanza en el vivir a través de la política ${ }^{297}$. Tanto para Aristóteles como para Cicerón el hombre tiene una naturaleza inherentemente política, y por ello tiene una fundamento cívico a priori que ha de desarrollar en la participación cívica en la ciudad, estas ideas las retoma Cartagena, y además las engarza con los ideales cristianos (en la línea del aristotelismo cristiano tomista), conjugando la ciudad física con la ciudad moral. Para nuestro autor, este desarrollo de la virtud cívica se alinea y contribuye al objetivo teológico de la salvación.

El insumo ideológico de estos pensadores clásicos fue importante para que Cartagena sedimentase una idea central en su filosofía: la idea de servicio público en aras del bien común, noción en la que confluyen la filosofía moral y el ejercicio práctico de la política. Incorporará esta noción en el ideario moral de grupos como los caballeros, los nobles y los letrados, dándoles así un fundamento moral más allá del prestigio personal. Muy hábilmente, Cartagena logra desplazar la noción de honor -vertebral en el pensamiento hispánico- de una esfera privada vinculada a la idea de fama y de obligación estamental, hacia una esfera moral y colectiva. Ahora el honor lo acarreará la acción virtuosa en la vita activa. Además, esta idea de servicio público será interiorizada como deber moral. Ahora, el caballero, el noble, el estudioso, tendrán un ethos y una teleología cívica basados en su función como servidores públicos a través de cargos que impliquen la participación cívica, y que contribuyan al bien común. Así, quedan ligadas las

${ }^{297}$ Villacañas (2005c): 14. 
nociones de bien común y de Estado. Se pondrá al servicio del Estado el paradigma moral aristotélico materializado a través del vivere civile. Pero además, hay otro interesante pliegue: esta teleología cívica implica además un triunfo moral que acerca a la virtud cristiana y a la teleología de la salvación, que es el fin último. Por lo tanto: teleología cívica y teleología cristiana de la salvación se orientan en una misma dirección. Coincidimos en esto con José Luis Villacañas o con Miguel Fernández Gallardo; según las palabras de este último, Cartagena contribuye a transformar el ethos individualista para ser dotado de una profunda dimensión cívica; indica también este académico que: «Alonso de Cartagena hará una importante aportación: la originalidad de su pensamiento político radica en la profunda inspiración ética básicamente aristotélica - que en él subyace, de manera que el límite a las pretensiones autocráticas de la realeza lo constituyen precisamente principios morales rigurosamente definidos conforme al paradigma aristotélico» ${ }^{298}$.

Cartagena era consciente de que para consolidar estas ideas, era preciso que la dimensión ética fuese una constante en la educación de príncipes, caballeros y nobles, así ellos podrían interiorizar su función de servicio público. Todo parece quedar tocado por esa vocación ética de servicio público, así el letrado se torna también un servidor público, ante todo en su papel de jurista, y se dignifica en esta condición. Lo mismo sucede en general con otras ocupaciones, que se dignifican al vincularse a al bien común, por ejemplo, los caballeros, para los cuales se configura una ética de la virtud caballeresca hidalga según la cual el éxito militar es síntoma de excelencia moral, y según la cual la pertinencia del rol social del caballero se materializará a la lucha contra la herejía en pro de la unidad religiosa y en la búsqueda de paz social para la convulsa Castilla del siglo XV. Por ello, obras de Cartagena como el Memoriale virtutum, la Questión o el Doctrinal de caballeros, tienen un claro objetivo pedagógico, son un compendio de enseñanzas morales: además del código moral cristiano, han de transmitir estas obras los principios de la ética aristotélica y de los valores republicanos ciceronianos. Las traducciones que de Cicerón hizo Cartagena tenían también este fin de pedagogía moral, además, para el pensador castellano, las obras de aquél eran óptimas para este interés ilustrativo, pues representaban un perfecto equilibrio entre filosofía y elocuencia, por lo que eran accesibles y atractivas al lector susceptible se recibir las enseñanzas.

${ }^{298}$ Fernández Gallardo (2002): 333. 
Son también destacables como rasgos republicanos en Cartagena sus reflexiones acerca del origen de la autoridad o potestas, así como acerca de los límites de dicha autoridad. Una necesidad de observancia para evitar el uso arbitrario de la autoridad que puede ser vía el control legal y las Cortes, o vía la expectare de los súbditos hacía el rey (algo propio de la teoría organicista del principado). Esto último del organicismo no le era para nada ajeno a Cartagena, que en muchas ocasiones hace uso de dicha identificación. Por ejemplo, expone en su Qüestion: «Non guarda la república quien desirue a su rey nin sirve a su rey quien daña al pueblo, segund diríamos que non guarda bien el cuerpo del omne quien le fiere en la cabeça nin le guardaría bien la cabeça quien le firiese en el cuerpo, ca todos los mienbros son coligados e comunican virtud vnos con otros por la proporçión de sus influençias, de guisa que el daño del vno al otro se estiende» ${ }^{299}$.

Más adelante, en el próximo capítulo, nos referiremos con detalle esta cuestión de la metáfora organicista en un apartado específico al comentar el Defensorium y analizar cómo emplea nuestro obispo dicha metáfora: ya no sólo en su dimensión política republicana, sino también en su desarrollo paulino de Iglesia como cuerpo místico de Cristo, para así argumentar en pro de la igualdad y cohesión de los cristianos, de su igualdad de "derechos" tengan el origen que tengan, siendo este uso del organicismo, según sostenemos, otro rasgo particular de su teología política.

Abordar la postura de Cartagena acerca de la cuestión del origen de la autoridad o potestas, nos lleva a hablar de su concepción de la monarquía. Respecto al tema del origen del poder real pudiera parecer algo ambigua la postura de Cartagena, pues en su Defensorium unitatis christianae pareciera a priori apoyar un enfoque de cariz casi teocrático - aunque matizaremos esto en seguida y veremos que no es así- y, sin embargo, de los textos De preeminentia y De allegationes, las obras escritas en el ámbito del Concilio de Basilea y de mayor calado político, se destila afinidad con las teorías iusnaturalistas y republicanas sobre el origen de la autoridad, situando el origen del poder real en la comunidad política. Cartagena tiene un enfoque providencialista de la monarquía, es decir, la figura del rey ha sido instaurada

\footnotetext{
${ }^{299}$ Edición de Gómez Moreno (1985): 357.
} 
por designio divino, y tiene el cometido, al ser el rey vicario de Cristo, de velar por la cristiandad, pero esto no implica ni es para nada incompatible con la idea de que la potestas fuese transferida en un origen por Dios al pueblo (a la comunidad política), y de éste luego al monarca. Esto es diferente de la postura teocrática que se usará para justificar al absolutismo y según la cual, la autoridad es transferida al monarca directamente por Dios. Basándose en el Digesto, Cartagena en De preeminentia (1434) — texto dirigido al Concilio- sostiene la transferencia de la autoridad del pueblo al monarca, ya que en un inicio Dios transfirió al pueblo dicha potestas. Afirma Cartagena:«Nam licet potestas regalis sit a Deo, tamen per ministerium populi inceperunt regna (...) hoc solum sufficiat dicere, quod cum a Deo per ministerium populi inceperunt regna.» (que el propio Cartagena traduce como «E es de saber que aunque el poderío real sea dado por Dios, pero los regnos començaron por ministerio e acto del pueblo, e esto por sí solo es suficiente para deçir que los regnos començaron por ministerio e acto del pueblo») ${ }^{300}$. Al respecto explica Fernández Gallardo ${ }^{301}$ :

La tensión entre una dimensión trascendente y una perspectiva humana, que deriva en una mística del poder real, viene a representar la solución de compromiso entre el pensamiento teológico y el aristotelismo, cuya premisa antropológica —el hombre como animal político - tendía a imprimir un sesgo humano, inmanente, al discurso político, lo que podía derivar a posiciones «populistas» (...) El planteamiento de De preeminentia adquiere pleno sentido en el contexto conciliar. Y es que, en efecto, la tesis populista, que tras su maduración en la doctrina de Azo, cayera en el descrédito de los juristas del siglo XIV (Cyno de Pistoia, Bartolo de Saxoferrato), experimentó una renovación durante el Gran Cisma, para erigirse en fundamento de la autoridad de la Iglesia, que había que situar por encima de las pretensiones de los sedicentes papas.

En las Allegationes (1436 o 1437) la postura de Cartagena es similar. Es este escrito se refiere claramente a la transferencia de la potestas del pueblo al monarca, afirma «(...) Pues según la calidad del pueblo, se proporciona el poder a los que aspiran al mando, porque el poder universal se lo transfiere al príncipe el pueblo» ${ }^{302}$. Sin embargo, a lo largo de esta obra hay cierta ambigüedad, pues el concepto de principado se presenta también con cierto deje autocrático, esto

\footnotetext{
${ }^{300}$ Cartagena, De preeminentia (B.N.M., ms. 9262, f. 16r) y traducción castellana del propio Cartagena editada en Penna (1959).

${ }^{301}$ Fernández Gallardo (2003): 331.

${ }^{302}$ Cartagena Allegationes, edición de González, Hernández y Saquero (1994): 130. La traducción es nuestra, el texto original es: “(...) nam secundum qualitatem populi proportionatur imperium principantis, quia a populo in principem est translata universalis potestas».
} 
último quizá se explique teniendo en cuenta que es un texto dirigido al Papa y parecer demasiado conciliarista podría ser conflictivo. De todos modos, teniendo en cuenta el contacto de Cartagena — precisamente en el Concilio de Basilea - con el auge de la recuperación de las ideas republicanas clásicas (recuperación de la que participó junto con otros intelectuales, sobre todo los italianos), y teniendo también en cuenta la sólida formación como civilista de nuestro autor y su aristotelismo, es lógica esta postura de Cartagena acerca del origen de la autoridad. Coincidimos de nuevo con Fernández Gallardo en esta reflexión ${ }^{303}$ :

Y es que el naturalismo aristotélico ofrecía una rigurosa respuesta a la cuestión del origen histórico del poder, aspecto éste (la transferencia desde el pueblo al príncipe) del que difícilmente podía prescindir un intelectual tan exigente como Alonso de Cartagena. El Digesto permitía integrar el indubitable principio del origen divino del poder en un planteamiento naturalista; en definitiva, la conjunción de las perspectivas teológica e histórica. (...) A su vez, no deja de ser significativo que dos años después del éxito oratorio alcanzado con De preeminentia, se defendieran, en el marco académico salmantino, los puntos de vista comunitarios sobre la base, precisamente, de la doctrina aristotélica: la «repetitio» de Alfonso de Madrigal intitulada De optima politia, un comentario al libro II de la Política del Estagirita

Por el propio tono retórico laudatorio hacia el monarca, frecuente por ejemplo en el Defensorium, podría parecer - erróneamente a nuestro entender- que Cartagena mantuviese una postura casi teocrática respecto a la monarquía, pero recordemos que esto no es así y que providencialismo no es lo mismo que teocracia, y que el origen de los atributos del rey puede ser divino - dada su función de vicario de Cristo - y esto no implica que tengamos que hablar de teocratismo (ni en cuanto a la cuestión de la transferencia de la potestas ni en cuanto al liderazgo del gobierno de lo espiritual y de lo temporal a la vez). Lo que sí salta a la vista, es el enfoque providencialista de nuestro autor en cuanto a su concepción de la monarquía. Se aprecia, por ejemplo en este pasaje del Defensorium: «Raramente se hallará que los que trabajan con gran empeño en algún nuevo error contrario a la fe católica no se lancen contra la soberanía de los príncipes de la tierra, teniendo en cuenta que la potestad de los reyes y de los príncipes de este mundo depende de la misma eterna y divina potestad, según aquello de que no tendrías ningún poder sobre mí si no te hubiera sido dado de lo alto» ${ }^{304}$. Es preciso apuntar aquí que el traductor Guillermo Verdín-Díaz usa el término «soberanía», pero éste no es adecuado y resulta

\footnotetext{
${ }^{303}$ Fernández Gallardo (2002): 330-332.

${ }^{304}$ Cartagena, traducción de Verdín-Díaz (1993): 357.
} 
anacrónico dado el momento en que está escrito del Defensorium; estimamos que hubiera sido más correcto usar, por ejemplo, «autoridad» (o «potestas», o «dominio»). No obstante, y volviendo a la cita, hacer notar que debemos ser cautos y comprender aquí que cuando nuestro autor dice «(...) teniendo en cuenta que la potestad de los reyes y de los príncipes de este mundo depende de la misma eterna y divina potestad», el verbo 'depender' no implica que dicha potestad se le haya dado directamente Dios al monarca. Según nuestra interpretación, esta frase refiere a la ligazón del rey a Dios como su vicario, pero no refiere a la cuestión de la transferencia de potestas. La idea que sostenemos es que es compatible un enfoque providencialista del monarca con una enfoque republicano sobre el origen de la autoridad, y un exponente de ello es Cartagena. Además, al encarar obras de este periodo encargadas por un monarca y/o dirigidas y dedicadas a él hay que saber destilar el tono de loa al monarca y entender que a veces responde a la circunstancia concreta que detonó dicha obra. Concretamente el Defensorium responde a una revuelta antimonárquica (además de antijudía y anticonversa, como veremos en el capítulo próximo) que aconteció en Toledo en 1449 contra Juan II, y por ello se requiere un discurso que ensalce la figura regia y magnifique el alcance de su poder ${ }^{305}$.

Cartagena defiende el papel de un rey garante de la fe y con el cometido y la obligación de proteger a la Iglesia, luchar contra la herejía y salvaguardar la paz (éste es para él un concepto religioso que implica la unidad de la fe). Tal vez el pliegue que tengamos que desentrañar es que se puede ser vicario de Cristo, esto es, representar a Dios en la Tierra y cumplir el mandato encargado por Dios de proteger la fe, pero esto no pasa necesariamente por asumir un origen teocrático del poder real y la unificación entre lo civil y lo espiritual que esto implica. Es decir, no implicaría este vicariato una legitimación para el uso ilimitado del poder por parte del monarca sin controles. El rey podrá cumplir con un cometido religioso por mandato divino, pero su ejercicio del poder ha de estar sujeto a Derecho, pues el origen de este poder le fue otorgado por una transferencia de la potestas del pueblo a él. Lo que tratamos de plantear es que parece probable que en Cartagena, y el pensamiento converso aledaño, la concepción de la monarquía esté dentro de en esta dialéctica, y que la síntesis que la resolvería podría ser sea la siguiente figura que proponemos: la de una suerte de rey-profeta, pues el profeta guía y protege en lo espiritual, pero se somete a la Ley, pues él es un enviado de Dios, pero no es de naturaleza divina

\footnotetext{
${ }^{305}$ Acerca de ello nos detendremos con detalle en el Capítulo 4.
} 
necesariamente, esto, además, encajaría con un profetismo de raigambre hebrea. El ser vicario de Cristo encaja aquí con lo profético, no con lo teocrático, además Cartagena comparte valores republicanos en cuanto a la cuestión de la necesidad de límites en el ejercicio de la autoridad real.

La pregunta a este respecto sería si, a diferencia de lo que pueda pensarse a priori y de la interpretación más usual, el hecho de tener que defender la fe como representante de Dios en la Tierra, como vicario, implica necesariamente una concepción teocrática de la cuestión del origen y transferencia de la autoridad, si implica automáticamente un origen divino de la potestas. A lo que respondemos que no, por las razones arriba explicadas. Puede ser revelador el responder a esta pregunta en la dirección de que el que Dios dé un cometido al rey no implica que el rey sea de naturaleza divina, y entonces su vicariato sería compatible con una transferencia de poder de Dios al pueblo y luego de éste al rey, en línea más con las teorías populistas. Además, por otro lado, en el catolicismo, el liderazgo del gobierno espiritual le corresponde al Papa, el rey, vela por el orden espiritual, pero no lidera la Iglesia.

Por todo lo anterior, asumimos que el apoyo de Cartagena a la monarquía no parte de una concepción teocrática de la misma (que, además, de hecho, como vimos en el capítulo 2, no es propia del catolicismo). Para nuestro autor, su apoyo a institución monárquica pasa por la comprensión de que se da una transferencia inicial de la potestas, o dominio, por parte del pueblo al rey. Y pasa también por la necesidad de creación de una base comunitaria fuerte, que, además, tiene doble naturaleza: ser comunidad política y ser comunidad religiosa unida. Como explicábamos, y tal y como lo entendemos, una cosa es una teocracia que niega la transferencia de potestas pueblo $\rightarrow$ rey, y otra distinta es que se tenga una visión profética o mesiánica del monarca, incluso providencialista, en la que el rey como vicario de Cristo haya de cumplir la misión, de velar contra la herejía. Lo que tratamos de decir es que cuando solamente hay enfoque teocrático hay justificación para el uso indiscriminado y absoluto del poder porque no se contempla la transferencia de autoridad del pueblo al gobernante, pero no es así en un enfoque que incorpora rasgos providencialistas y proféticos, pues no por ello se anula dicha transferencia de la potestas del pueblo al monarca, idea la cual siempre fue contemplada en marcos normativos como el Digesto. 
En relación con esta cuestión del origen y la transferencia de la autoridad, resulta muy interesante la apreciación de Francisco Castilla ${ }^{306}$ :

Pero don Alonso no se conforma con esta subordinación, sino que aspira a establecer un vínculo entre pueblo y monarquía que justifique aún más el ejercicio del poder (...) no ofrece terreno alguno para la contradicción en el imaginario medieval. En el caso del obispo, la doble legitimidad parece remitir, de acuerdo con su permanente búsqueda de apoyo a la institución monárquica, por una parte, a la consideración del rey como vicario o ministro de Dios, lo que acentúa el deber de obediencia por parte de los súbditos, pues resistir al rey que actúa en nombre de Dios es resistir al orden de Dios mismo. Por la otra parte, la que enlaza el poder real con el pueblo, se estaría si no ante una elección, sí al menos ante una aceptación popular en virtud de la cual se transferiría al rey una legitimidad que le situaría por encima de cualquier otro poder.

Muestra también Cartagena su vocación de respeto por la legalidad, en el sentido de que estima que la legitimación del poder ha de hacerse a través de un seria justificación jurídica, justificación que hunde sus raíces en el del derecho común romano y de la tradición jurídica local (pensemos en el peso de la tradición Alfonsina al respecto, en la pervivencia de Las Partidas). Cartagena dota de rango de verdad a la jurisprudencia. Como icono de hombre de transición que habita - y enriquece - el intersticio entre dos paradigmas intelectuales, no renuncia al discurso, hecho propio, de la cultura jurídico-escolástica. Destaca por ejemplo, cómo en la Allegationes, donde se defiende la legitimidad y pertinencia de la conquista de Canarias por Castilla frente a Portugal, Cartagena hace un esfuerzo jurídico por argumentar dicha legitimidad y que no parezca un acto arbitrario. Recupera y amplía nuestro autor los discursos jurídico-escolásticos en relación al tema de la legitimidad del dominio en tierras habitadas, o de la guerra justa. Cartagena se muestra reacio a la idea del uso indiscriminado del poder, incluso cuando medidas que él considera injustas se amparan en un marco normativo. Nos referimos a medidas como la medida segregacionista de los estatutos de limpieza de sangre (los cuales, en su Defensorium demuestra impecablemente que no tienen una sólida base en el Derecho y logra neutralizar desde el punto de vista jurídico), o como la idea de que los infieles, por el hecho de serlo, no ostentan los derechos propios del Derecho Natural, algo a lo que es contrario Cartagena, pues apoya que ya sean las personas infieles, gentiles, judías o de la religión que fuere sí ostentan los derechos

\footnotetext{
${ }^{306}$ Castilla (2012): 156.
} 
contemplados por el Derecho Natural (entendidos ya casi como Derechos subjetivos). Veremos todo esto con detalle en el Capítulo 4 al analizar su Defensorium. Sin duda, estas actitudes de Cartagena se nos antojan como antecesoras de las importantes discusiones al respecto de la Segunda Escolástica.

Esta dimensión de Cartagena de inspiración republicana que aboga por el control de la autoridad desde lo jurídico, reiteremos que no implica una visión de la monarquía laica, pues, como ya hemos venido señalando, pensamos que la visión que nuestro burgalés tiene del rey, incorpora a la vez elementos propios de la teoría del principado organicista y del enfoque profético, propio del mundo converso; es decir, estimamos que conviven en la visión del monarca de Cartagena republicanismo, organicismo y profetismo, además todo ello refundido con la visión mítica atávica del monarquía hispánica. Acerca del organicismo monárquico, y sus mecanismos de control al monarca, basados éstos en la expectatio hacia el monarca virtuoso, la relación de sinécdoque confusiva entre éste y el pueblo, y el derecho a la legítima deposición del monarca si éste actúa como tirano, hablamos ya con detalle en el punto 2.5 del segundo capítulo.

La aproximación y narración que el obispo tuvo del monarca y de la institución monárquica no fue siempre unívoca ni fácilmente descifrable dada su condición de hombre de Estado que ha de cumplir con sus deberes propagandísticos, pero lo que es claro es que no cuestionó esta institución en ningún caso, y más que el apoyo concreto a un rey, su defensa fue transpersonal, fue de la institución. Por ejemplo, también es de justicia apuntar que tampoco es del todo clara la postura de Cartagena respecto a la cuestión de la obligada sujeción del monarca a la ley positiva, pues también contempla transversalmente en sus escritos la idea de que el rey tiene criterio para poder legislar cuando se da una situación en la que la ley positiva no resuelve una situación de conflicto social o político. En esos casos se apela al «poderío real», lo que da al rey eventual capacidad de decisión (incluso por encima del derecho positivo, como ya explicamos en el punto 2.6 del capítulo anterior) confiando en la razón natural del monarca. Detrás de esta situación subyace la problemática tensión entre ley positiva y ley natural, y al respecto Cartagena parece apegarse a la postura tomista, que fundamenta la ley natural en la razón. 
Retomando esta idea que sostenemos del profetismo regio, recordemos el artículo de José Manuel Nieto Soria que citábamos en el capítulo segundo al respecto, texto que partía de la pregunta «¿Existió una sensibilidad distintiva y característica hacia la concepción del poder regio entre los intelectuales conversos en la Castilla del siglo xv?» ${ }^{307}$. Dicho artículo se centra en Hernando del Pulgar (discípulo de Cartagena), pero es aplicable al espectro del pensamiento político converso, y por su puesto a nuestro autor. Explica Nieto Soria que aunque él no está de acuerdo con homogeneizar la visión que del rey tenían los pensadores novocristianos, sí es indudable que éstos compartían ciertos enfoques al respecto, sobre todo el «enfoque de la realeza de índole religiosa, en el que los contenidos mesiánicos, profetices y providencialistas ocupan un lugar central» ${ }^{308}$. Realidad ésta que, como también afirmamos, José Cepeda Adán vincula claramente a su origen cultural hebreo ${ }^{309}$.

Ya haciendo alusión directa a los Santa María, a Pablo, padre de Alonso, y a éste mismo, Nieto Soria reconoce su definitorio papel al proveer a otros intelectuales de herramientas de reflexión sobre el sentido de la monarquía castellana para poder así justificarla y legitimarla desde lo bíblico y lo histórico (mítico muchas veces). E insiste el profesor en esta veta de mesianismo que exponemos ${ }^{310}$ :

Si es posible hallar unos fundamentos nítidos del milenarismo y del mesianismo aplicados a las concepciones de la realeza que se muestran de forma tan características a fines del siglo xv, éstos pueden encontrarse con toda facilidad en Las siete edades del mundo, de Pablo de Santa María. Del mismo modo que la Anacephaleosis, de Alfonso de Cartagena, aporta elementos decisivos en orden a dotar a la monarquía castellana de un basamento ideológico respaldado por una trayectoria histórica difícilmente parangonable en todo el mundo occidental

\footnotetext{
${ }^{307}$ Nieto Soria (1993): 232.

${ }^{308}$ Nieto Soria (1993): 246-247 Recordemos cuáles son estos rasgos compartidos: «1) La presencia de una preocupación muy difundida por establecer elementos de reflexión intelectual sobre el nuevo sentido que parecía que iba tomando la institución monárquica. 2) El pensamiento teológico-político orgánicamente expresado a partir del siglo XIII y ampliamente difundido durante el siglo XV. 3) La incidencia de los textos bíblicos, sobre todo los veterotestamentarios. 4) Las expresiones de las tendencias autoritarias que pretende desarrollar la monarquía en su proceso de configuración de una solución estatal (... 5) La visión histórica de una monarquía castellana (...)». Nieto Soria (1993): 246-247.

309 «En su estilo y, sobre todo, en su mesianismo aparece clara esta huella de su origen. Pulgar, cristiano nuevo, aunque de la más limpia ortodoxia, está empapado de hebraísmo en sus juicios históricos. No concibe la Historia sin una intervención decidida y final de Dios. Sus palabras tienen a veces acento bíblico y resuenan como una voz profética». Cepeda Adán, José (1959): “El providencialismo en los cronistas de los Reyes Católicos", en Arbor, n. ${ }^{\circ}$ XVII, págs. 179-80. Tomo la referencia de Nieto Soria (1993): 237, nota al pie número 30.

${ }^{310}$ Nieto Soria (1993): 245.
} 
No podemos negar la contribución de Cartagena al andamiaje ideológico de la institución monárquica castellana, por su parte, Eloy Benito Ruano hace notar cómo esta construcción de las imágenes de realeza se realiza de acuerdo con la solidez de la ciencia jurídico-escolástica ${ }^{311}$. Francisco Castilla resalta su patriotismo y su contribución a una visión de la monarquía castellana como unitaria y no sujeta al imperio dado su pasado godo, además la dota de superioridad frente a otros reinos peninsulares, atribuyendo a la castellana la potestad de encarnar y representar a toda la monarquía hispánica, recuperando el mito isidoriano ${ }^{312}$.

Esto nos lleva a la cuestión del goticismo de Cartagena ${ }^{313}$. Los grandes baluartes discursivos de Cartagena en la defensa de éste, según el estudioso José María Monsalvo, son: la antigüedad de la monarquía castellana, que se remonta a tiempos prerromanos, los godos como forjadores de España y de los que descendían lo reyes de Castilla, los logros para la cristiandad obtenidos en la Reconquista dando a los reyes castellanos un plus de defensa de la religión único en Europa y la variedad de gentes, lenguas, culturas y tierras que conforman Castilla, lo cual Cartagena ve como un signo de riqueza y grandeza ${ }^{314}$. En sus Allegationes super conquesta Insularum Canariae contra Portugalenses (1436 o 1437) —en las que Cartagena emplea el argumento goticista para fundamentar los derechos territoriales de Castilla sobre las Islas Canarias frente a los de Portugal - dice así: «Está arraigado en los corazones de los hombres que el reino [visigodo] de Hispania tiene su continuación en los reyes de Castilla y [...] todos los pueblos que están fuera de Hispania, tanto limítrofes como alejados, siempre usaron el primer título, denominando rey de Hispania solamente al rey de Castilla» ${ }^{315}$. Y en su De precedencia sostiene: «Los reyes de España, entre los quales el principal e primero e mayor es el rey de Castilla e de León, nunca fueron sujetos al emperador» ${ }^{316}$. Hace notar José Luis Villacañas que detrás del goticismo de Cartagena y su pasado idealizado del periodo godo estaba también el

\footnotetext{
${ }^{311}$ Benito Ruano (1961).

312 Castilla (2012): 143.

${ }^{313}$ Ya explicamos este concepto en la sección 2.5 del capítulo segundo.

${ }^{314}$ Monsalvo (2010): 64.

315 Cartagena Allegationes, edición de González, Hernández y Saquero (1994): pp. 121- 123.

${ }^{316}$ Cartagena (edición de De precedencia editada por Penna 1959: 210).
} 
anhelo de a una política que no estuviera marcada por la violencia endémica dentro de la propia Castilla; Cartagena siempre abogó por la estabilidad y la consolidación de la paz ${ }^{317}$.

Por su parte, Fernando Miguel Pérez Herranz piensa que el goticismo de Cartagena no ha de verse como un retroceso, sino que ha de interpretarse bajo la lógica de un converso que pretende la asimilación (así puede inferirse de su Anacephaleosis): los godos se convirtieron al cristianismo igual que ahora lo hacían los judíos, y en el proyecto ideológico de nación de estos pensadores del cuatrocientos castellano, los conversos tenían su cabida. Como también sostiene dicho autor, Cartagena construye un relato que ni es providencial ni es imperial: es peninsular ${ }^{318}$.

Acerca de la vehemente defensa de Cartagena de la institución monárquica, opina Francisco Castilla ${ }^{319}$ :

Tal vez la procedencia hebrea de Cartagena no sea ajena a la fidelidad al monarca y a la institución regia, que siempre favoreció a los judíos y a los conversos, frente a una plebe que les manifestaba constantemente su animadversión y que recurría periódicamente a episodios de violencia y rapiña contra ellos. Probablemente no sea casualidad que la mejor expresión literaria de su genio a favor de los conversos, el Defensorium Unitatis Christianae, sea uno de los escritos donde la devoción por el poder real alcance mayores cotas. Sin embargo, sería empobrecedor y delataría una filosofía de la sospecha poco acorde con los parámetros doctrinales predominantes en la época, interpretar esta ideología como un artificio estratégico o una concesión a la propaganda; por el contrario, hay que considerarla una característica muy arraigada en su pensamiento, pues prácticamente en todas sus obras es posible apreciar esta mezcla de patriotismo y legitimación de la institución monárquica que tan presente iba a estar en los escritos de intención política del siglo XV.

De todos modos, conviene aclarar en nuestra opinión que Cartagena, más que apoyar a un rey concreto, por lo que aboga es por la institución monárquica como tal (concebida tal y como expusimos en el Capítulo 2, puntos 2.5 y 2.6): son los aportes de dicha institución en genérico lo que alaba y lo que exhorta a mantener con vigor, y aboga por un modelo de gobierno mixto. Coincidimos, asimismo, con estas palabras de Pérez Herranz: «Autores como Cartagena, Valera o Madrigal no creen tanto en la virtud de la persona del rey como fuente de armonía social, sino

\footnotetext{
${ }^{317}$ Villacañas (2005b) p.18.

318 Pérez Herranz (2016): 296-297.

${ }^{319}$ Castilla (2012): 144.
} 
más bien en alguna institución intermedia, como el Consejo Real, para consolidarla»; como indica este estudioso, es cierto que en el reinado de Enrique IV no estaba consolidada una mediación política entre el poder y las funciones de la res pública, y es, precisamente, el círculo de intelectuales conversos afines a Cartagena el que intentó establecer los mecanismos de esa mediación $^{320}$.

Probablemente - como hombre de Estado que era - Cartagena fuese ya consciente de las dificultades y limitaciones que la monarquía castellana tenía para lograr aglutinar, producir y representar una comunidad cohesionada de adhesión a ella (algo que, sin embargo, sí lograrían años después los Reyes Católicos, gracias a ciertas medidas y a un impresionante aparato propagandístico), y por ello recurriese a un ideal de lo que era y había de ser la monarquía castellana revisitando el concepto isidoriano de monarquía hispánica y remitiendo a sus orígenes míticos, al proyecto de unidad peninsular que simbolizaba el rey godo Sisenando, y a la dimensión de Castilla como adalid de la cristiandad.

En cualquier caso, lo que más nos interesa señalar ahora desde el punto de vista de la teoría política, es otro aporte de don Alonso: el delimitar el poder real desde el derecho civil. Así lo explica Fernández Gallardo: «Alonso de Cartagena va a fundar sobre los sólidos fundamentos del Derecho Común los derechos del titular de la Monarquía Hispánica. Aplicará para ello la doctrina civilista del príncipe, que asume en su formulación un claro sesgo autocrático, mas no sobre fundamentos teocráticos, sino jurídicos»» ${ }^{321}$.

Esta actitud de Cartagena no se excluye con lo que veíamos anteriormente al hablar de que Cartagena en sus textos De preeminentia y Allegationes reivindicaba el principio populista que sostiene la transferencia del poder del pueblo al príncipe en lo que atañe a la cuestión del origen de la autoridad real. El meollo del asunto que queremos resaltar aquí es la sujeción al Derecho del monarca, incluso aunque el rey se acogiese a cláusulas de sesgo autocrático como el iurisdictio o el poderío real absoluto, pues estas cláusulas ya estaban "previstas" jurídicamente, por así decirlo. Esto es, ya estaban contempladas por el Derecho, y por ello no habría una actitud

\footnotetext{
${ }^{320}$ Pérez Herranz (2016): 298-299.

${ }^{321}$ Fernández Gallardo (2002): 394.
} 
tiránica en el monarca, no habría en él arbitrariedad y desprecio por el Derecho. Sin duda, para Cartagena este pilar jurídico es fundamental, en ello emerge su naturaleza de jurista y en ello adivinamos una actitud predecesora de lo que sería la tradición del pensamiento hispánico de aplicar las grandes cuestiones jurídicas para resolver los problemas socio-políticos de la realidad circundante y los dilemas morales que ésta pudiera entrañar. Aquí Cartagena actúa como lo harán los grandes juristas del XVI, es uno de los pensadores que en línea con lo que implicó el pensamiento político converso y en herencia de la escolástica medieval tomista, consolida una forma de hacer que seguirán nombres tan relevantes como Francisco de Vitoria, Francisco Suárez, Domingo de Soto, Juan de Mariana o Fernando Vázquez de Menchaca.

No vamos a extendernos más en la concepción de la monarquía de nuestro autor, pues esto, si bien resulta muy interesante, no es en torno a lo que quiere pivotar nuestro acercamiento a Cartagena, que sí pretende hacerlo, sin embargo, en torno a su teología política. Ello con el objetivo de poner en valor la teología política de Alonso de Cartagena contextualizándola en su matriz intelectual, que es el pensamiento político converso castellano del siglo $\mathrm{XV}$, y destacando cómo articula rasgos republicanos (que repetimos, no son excluyentes con su apoyo a la institución monárquica) con elementos teológicos.

Si bien Cartagena pareciera apoyar en ocasiones un intervencionismo estatal activo en pro de la conversión y una concepción del monarca como vicario de Cristo, lo que pretendemos indicar es que esto ni implica ni cimienta su teología política en una teología imperial absolutista basada en un enfoque teocrático del rey, sino que su teología política se sustenta en la traductibilidad de conceptos religiosos redimensionados como agentes otorgadores de ciudadanía, y en la noción de pueblo. Sin embargo, tampoco se vertebra su discurso en la idea de pueblo elegido al modo tradicional mesiánico de la teología hebrea.

Para entender la teología política de nuestro obispo, su originalidad, hibridación y utilitarismo, hemos de entenderla desde su contexto intelectual converso: al igual que Spinoza (pese a ser éste marrano), Cartagena tiene una concepción de la religión como «religión pública», concepto que tomo de Villacañas ${ }^{322}$. Éste, al hablar de Spinoza, entiende que en su

\footnotetext{
${ }^{322}$ Villacañas (2012c).
} 
Tratado teológico-político lo religioso está presente en lo político, y lo está para poder administrar la contingencia y construir un Estado con una comunidad política unida en la esperanza; en esto coincide con Cartagena, aunque es evidente que hay entre ambos claras diferencias.

Conviene señalar que Cartagena no utiliza la noción de pueblo en un sentido identitario cerrado y fijo (evitando así las tensiones derivadas de los esencialismos y naturalismos que entraña en ocasiones la idea de "identidad", y como muchas veces es empleado el término en el discurso oficial), sino más en un sentido relacional y abierto, esto es, de comunidad cohesionada por un rasgo en común, pero receptora. Y además comunidad activa políticamente; como explica Maurizio Viroli la creación del pueblo y la fundación del Estado se ligan, precediendo el pueblo conceptualmente al vivir libre republicano ${ }^{323}$.

En un pliegue que incorpora elementos republicanos lo que centra la teología política de Cartagena (con el Defensorium unitatis christianae como epítome) es la idea de un pueblo que es potencialmente ciudadanía activa y libre, y que deviene ciudadanía precisamente vía una instrumentalización de elementos religiosos — principalmente el bautismo- que se tornan herramientas de dignificación y posibilidad de participación en el vivere civile. Es a través de la religión como Cartagena quiere implementar una ratio de la inclusión y la cohesión (concepto éste de unidad engarzado también con el organicismo), esto es, su defensa de la unión de los cristianos es también defensa de la conformación de base comunitaria, de comunidad política solidaria y participativa frente a la ratio de la exclusión y la dominación que se estaba imponiendo en el albor de la Modernidad hispánica. Acerca de esto versará el capítulo que sigue en el que abordaremos su texto Defensorium unitatis christianae.

\section{Conclusiones y aportes del Capítulo 3.}

En este capítulo de ha presentado al autor Alonso de Cartagena y a su producción textual, así como elaborado una aproximación a algunos aspectos de su pensamiento político. Con ello se ha cumplido el objetivo planteado para este capítulo de visibilizar a dicho autor, y sobre todo de

\footnotetext{
${ }^{323}$ Viroli (1992).
} 
visibilizar su pensamiento político. Pese a haber tenido una importancia crucial en el siglo XV, tanto castellano como europeo y haber estado en primera línea en los debates intelectuales del momento, Alonso de Cartagena ha sido descuidado por la historia intelectual y la historia de la filosofía política (sobre todo, como hemos argumentado, como consecuencia de una polémica suya con Bruni y como consecuencia también del silenciamiento al que fue confinado en Castilla por ser converso). No obstante esto, su impronta en el pensamiento político de la Segunda Escolástica y en la conformación del llamado pensamiento hispánico fue innegable.

Hemos mostrado también que Cartagena participa de las características propias del pensamiento político converso (aunque para completar esto será preciso también el siguiente capítulo), corriente cuyos rasgos y catalizadores habíamos estudiado en los capítulos anteriores, y los cuales es fundamental tener en cuenta para poder comprender en toda su profundidad y sin juicios superficiales a Cartagena.

Normalmente, se ha abordado a dicho autor desde el ámbito filológico, por tanto, ya el reivindicar su peso intelectual en la historio del pensamiento político y el encarar su figura desde el espectro de la filosofía política suponen un aporte de este capítulo. Además, opinamos que en la mayoría de ocasiones - salvando excepciones de algunos relevantes investigadores - se lo ha prejuzgado y malentendido, interpretándolo tan sólo como un rigorista canónico. De ahí que también nuestro aporte en este capítulo haya sido el exponer ciertos debates de la crítica en torno a si pude considerarse o no un humanista, y estudiarlo como un teólogo y hombre de Estado que, según nuestro criterio, se perfila como figura de transición epocal.

Asimismo, hemos querido demostrar, como anunciábamos en la introducción a este capítulo, que su pensamiento hibrida tanto elementos de la tradición escolástica medieval como elementos propios del pensamiento político renacentista, y que Cartagena aglutina en su persona rasgos de diversas tradiciones intelectuales y culturales (de ahí ciertas ambivalencias que la crítica ha visto en él y que, como hemos explicado las páginas anteriores, no han de interpretarse como paradojas). Para ello nos hemos detenido en su capacidad de ligar el pensamiento político clásico con el cristianismo, en su recuperación a través de su labor de traducción de autores como Séneca y Cicerón, en su aristotelismo, en su defensa de la noción de servicio público 
ligada al valor republicano de desarrollo de vida activa en el vivere civile a través de la participación cívica en pro del bien común, en la alineación en su pensamiento de una teleología de la virtud cívica con una teleología cristiana de la salvación, en su conciliarismo, en la vocación pedagógica — en la línea de la enseñanza moral— de la que dotaba a sus trabajos, en su rigor jurídico y en su concepción de la monarquía. Acerca de esta última cuestión nos hemos explayado algo más, y hemos comprobado que Cartagena defiende el origen popular de la autoridad real, la conveniencia de dotar de límites al ejercicio de ésta, y que defiende una visión providencialista pero no teocrática del monarca. Su noción de la monarquía incorpora además ideas del organicismo monárquico y elementos propiamente hispánicos como el profetismo converso o el goticismo.

En las páginas previas, asimismo, hemos probado que el pensamiento político de nuestro autor tiene más capas de las que se han señalado normalmente, y que, además, incorporó elementos de enorme actualidad para su contexto. No hemos abordado aquí aún en profundidad su teología política, punto central de nuestro interés en Cartagena, y la cual, según la tesis que sostenemos, articula elementos teológicos con elementos republicanos. No hemos entrado en dicho aspecto porque a ello dedicaremos enteramente el siguiente capítulo, donde analizaremos su texto cumbre, el Defensorium unitatis christianae, para sustentar la tesis de dicha articulación. 


\section{CAPÍTULO 4: Teología política y pensamiento republicano en el Defensorium unitatis}

christianae (1449).

\section{Introducción al Capítulo 4.}

En este cuarto y último capítulo de la tesis, procederemos a aportar una base textual que sustente lo anteriormente aseverado y argumentado acerca del pensamiento político converso y de la teología política de Alonso de Cartagena. Con esta fundamentación textual en una fuente principal de la época, permitimos demostrar y dar solvencia a las hipótesis mostradas a lo largo de este trabajo, cerrando así su estructura y posibilitando localizar en una base textual los rasgos específicos señalados como intrínsecos de este pensamiento político converso, satisfaciendo con ello el objetivo principal de este trabajo, que era el visibilizar dicha manifestación del pensamiento político castellano del siglo $\mathrm{XV}$, así como visibilizar también el pensamiento de Alonso de Cartagena. Elaboraremos un análisis del Defensorium unitatis christianae (1449), pues consideramos esta obra como cumbre de la teología política de Alonso de Cartagena y epítome del pensamiento político converso.

Lo primero que realizaremos será una presentación de dicha obra y de la circunstancia que la cataliza. Elaboraremos también un apunte filológico y sobre su transmisión textual, así como un resumen de su contenido y un análisis del las fuentes que en este escrito - de formato escolástico - se toman como autoridades y en base a las cuales se estructura la argumentación. Asimismo, se hará una explicación del origen de este texto que nos ocupa, haciendo notar su dimensión como "obra de circunstancia" que denuncia el pogromo antijudío de Toledo de 1449 y la activación subsiguiente de los estatutos de limpieza de sangre, pero que, sin embargo, trascendió ese fin y acabó suponiendo no sólo una crítica jurídica de las políticas de exclusión en base a esencialismos de origen, sino también un tratado de convivencia, de revisión teológica y de búsqueda de conformación de comunidad política. Todo ello cimentado en la sugerente y original traductibilidad entre pensamiento republicano y teología, y en la voluntad de aplicabilidad de la universalidad de la gracia a conquistas civiles. Argumentaremos, asimismo, 
dónde entendemos que reside el valor de dicho tratado. Es precisamente la vocación universalista e inclusiva, y la dimensión del Defensorium como tratado de teología política y como guía para el diseño de un modelo de convivencia y de posibilidad de participación cívica, lo que pretendemos poner en valor.

Con el fin de responder con la mayor claridad posible a las siguientes preguntas: ¿cómo elabora Cartagena su ratio teológico-política en el Defensorium?, y ¿cómo es la presencia de elementos republicanos en la obra y su articulación con lo religioso?, configuraremos el análisis de la obra en torno a cuatro ejes : 1) Revisión teológico-histórica de la relación entre judaísmo y cristianismo. Creación de un nuevo pueblo a través de revelación 2) Uso de la metáfora organicista como argumento para la unión, solidaridad y equidad en la república cristiana, 3) Instrumentalización política de elementos teológicos para conformar una ratio de la inclusión y de acceso a la ciudadanía. El bautismo como posibilitador de acceso a la participación cívica. 4) Reacción ante el uso arbitrario de la autoridad. Desactivación jurídica de los estatutos de limpieza de sangre. Deslegitimación de las políticas de segregación.

Ya al final del capítulo llevaremos a cabo una breve reflexión sobre la impronta y marginación del pensamiento de Cartagena. Acabaremos así el cuerpo de esta tesis doctoral y daremos paso las conclusiones, en las cuales mostraremos las contribuciones que con ella hemos querido realizar y las sugerentes vetas para futuras reflexiones e investigaciones que, a nuestro entender, ha abierto la presente.

\subsection{Introducción al Defensorium unitatis chistianae: apunte filológico, explicación sobre el origen de la obra, resumen e índice de autoridades.}

Este extenso y solvente texto de Alonso de Cartagena, el Defensorium unitatis chistianae (también conocido como Defensorium unitatis fidei, aunque usaremos el primer y más popular título) podemos afirmar que fue escrito y publicado en 1449. A pesar de que los manuscritos en los que se conserva lo datan en 1450, tanto el moderno editor de la original versión latina (edición publicada en 1943), Manuel Alonso, como su reciente traductor en 1993, Guillermo Verdín-Díaz, sostienen que el Defensorium fue escrito entre los meses de junio y septiembre de 
$1449^{324}$. Compartimos este criterio, dado que el texto, como un poco más abajo explicaremos, es una inmediata respuesta a acontecimientos sucedidos en junio de 1449 y solicita una intervención papal que en efecto se dio en septiembre de dicho año, además, se interpela y rebate en el texto a una persona que fue ajusticiada en noviembre del citado año.

Seguiremos en este trabajo las ediciones que apuntábamos de Manuel Alonso y Guillermo Verdín-Díaz, ambas basadas en dos copias manuscritas de la obra (ambas derivadas del mismo original, aunque con muchísimas variantes entre ellos): la de la Biblioteca Nacional de España (mss. 442), del propio siglo XV, y la de la Biblioteca de la Universidad de Salamanca (mss. 2070) —en otro tiempo estuvo en la Biblioteca de Palacio, donde estaba catalogado como mss. 1642- ya del siglo $\mathrm{XVI}^{325}$. En ambos manuscritos los copistas añadieron el texto de las citas referidas (en el mss. 442 de la B.N.E., las anota al margen, el del mss. 2070 de la B.U.S. en el cuerpo del texto), pero en los dos dichas citas están reflejadas con cierta imprecisión, en muchas ocasiones memoria, como era usual entones, al igual que lo era que el copista añadiese a su criterio "modificaciones", "cortes" o "correcciones" con fin explicativo, algo que también sucede en los manuscritos a los que nos referimos. De acuerdo a lo que exponen Alonso y Verdín-Díaz, parece que el copista de el mss. 442 de la B.N.E tenía menos conocimiento del latín y que, además, el del mss. 2070 de la B.U.S. realizó una edición más cuidada y atenta, en la que abundan las correcciones.

Antes de pasar a señalar algunos rasgos formales de la obra, de indicar sus fuentes y de resumir su contenido, nos parece pertinente hacer algunos apuntes sobre las circunstancias sociopolíticas y teológicas que la generaron, pues nuestro texto se perfila como una 'obra de circunstancia' (aunque, como explicaremos, según nuestra visión, acaba trascendiendo por mucho este fin y conformando todo un tratado de teología política que resulta uno de los textos principales del pensamiento político converso, y promoviendo un programa de convivencia basado en una ratio política inclusiva). Además, para poder comprender el Defensorium hay que

\footnotetext{
${ }^{324}$ Alonso (1943, edición del original latino) y Verdín-Díaz (1993, traducción al castellano).

${ }^{325}$ De aquí en adelante, cuando citemos el Defensorium en la edición en latín a cargo de Manuel Alonso, lo haremos de la siguiente forma: Cartagena (1943), cuando citemos la traducción castellana elaborada por Guillermo Verdín-Díaz, lo indicaremos como Cartagena (1993). Sin embargo, cuando citemos palabras de dichos estudiosos o refiramos a sus ideas respecto al Defensorium, lo indicaremos así: Verdín-Díaz (1993) y Alonso (1943). Para más información acerca de la transmisión textual del Defensorium, puede verse Morrás (1991).
} 
contextualizarlo en el espacio controversial teológico generado en torno a la problemática de los conversos (cuestión ésta ya analizada en el punto 2.2 del segundo capítulo de esta tesis) y en los debates y reacciones detonados por los medidas discriminatorias contra éstos.

Pues bien, el texto que nos ocupa, fue originado como reacción a la revuelta de Toledo iniciada en enero de 1449, un revuelta motivada por dos ejes: reprobar el excesivo poder del rey Juan II y Álvaro de Luna en detrimento de ciertos privilegios a la ciudad de Toledo y mostrar el sentimiento antisemita. Dicha rebelión, que mantuvo sublevada y sustraída del poder real varios meses a la ciudad, prendió concretamente por una cuestión recaudatoria (pues se pidió dinero a la ciudad para campañas militares), pero sobre todo devino un pogromo antijudío y anticonverso (además muchos de los cargos públicos eran conversos, por ejemplo el encargado de las recaudaciones, Álvaro Cota). Acerca del trasfondo político e ideológico de esta rebelión, acaudillada por el alcalde de la ciudad Pedro Sarmiento, hay cierta controversia en la crítica, pensadores como Benzion Netanyahu o Eloy Benito Ruano la entienden más como un movimiento antisemita ${ }^{326}$. Otros autores como Albert Sicroff parten de que fue una revuelta emanada más de un sentimiento antimonárquico latente, algo con lo que parecen coincidir Nicholas Round y José Manuel Nieto ${ }^{327}$.

La revuelta trató de legitimarse a través de la Sentencia-Estatuto de Pero Sarmiento por varias vías: políticamente — para justificar la insubordinación al rey Juan II, al dudar de su legitimidad dada su indignidad, y apoyar en su lugar a su hijo Enrique IV—- jurídicamente basándose en un supuestos privilegios otorgados a la ciudad siglos atrás «por el cathólico y de gloriosa memoria D. Alfonso, Rey de Castilla y León», y doctrinalmente — tratando de justificar teológicamente las medidas discriminatorias contra los judíos y los judío-conversos dado su origen- ${ }^{328}$. Y en este último sentido encontramos el aspecto con más consecuencias de dicha revuelta y de su Sentencia-Estatuto, pues la limitación que ésta planteaba por motivos de sangre —instaurando los estatutos de limpieza de sangre que obligaban a demostrar que no se era de origen converso, esto es, que se era cristiano viejo, para poder ostentar un cargo público-

\footnotetext{
${ }^{326}$ Netanyahu (2000 y 2005), Benito Ruano (2001, 1961 y 1957).

327 Sicroff (1985) Round (1969) y Nieto (1998).

${ }^{328}$ El texto íntegro de la Sentencia-Estatuto está publicado en un anexo a la edición latina del Defensorium de Alonso (1943): 357-365. De ahí tomamos este fragmento. No queda claro a qué rey exactamente se refiere la Sentencia-Estatuto. Como explica Benito (2001), este punto ha sido objeto de duda y discusión por los historiadores.
} 
generaría numerosas reacciones entre los intelectuales que conformaban lo que hemos venido llamando pensamiento político converso. Además, esta idea de la limpieza de sangre acabaría por ser un factor social vertebral en el mundo hispánico durante las tres centurias siguientes.

La Sentencia-Estatuto, también presentada como Sentencia que Pedro Sarmiento, asistente de Toledo, y el Común de la Ciudad dieron en el año 1449 contra los conversos, fechada el 5 de junio de 1449 y redactada por parte de los regidores de la ciudad afines a Sarmiento, declaraba a los conversos y sus descendientes incapacitados para ostentar cualquier actividad pública, por considerar su fe sospechosa y por no considerarlos aptos ni moralmente válidos, reza así el texto: «Sean habidos e tenidos como el derecho los ha e tiene, por infames, inhábiles, incapaces e indignos para haber todo oficio e beneficio público y privado en la dicha cibdad de Toledo y en su tierra, término y jurisdicción: e ansí mesmo ser infames, inhábiles, incapaces para dar testimonio e fe como escribanos públicos o como testigos, y especialmente en esta cibdad ${ }^{329}$.

Lo más relevante aquí es incidir en cómo la Sentencia-Estatuto inhibía un aspecto fundamental como era el derecho a poder participar en la vida pública, en el vivere civile, a un importante grupo social como eran los conversos, cuyos intelectuales además, como ya explicamos en los capítulos previos, estaban embebidos de pensamiento republicano, por lo que para ellos, la participación cívica era definitoria. Al arrancarles a los conversos la posibilidad del desarrollo del ideal de vida activa y de logro de la virtud cívica a través del vivere civile, se les estaba arrebatando también una forma de alcanzar la virtud cristiana, pues para ellos - como también hemos venido explicando- la teleología cívica y la teleología de la salvación se alineaban. Además, se les despojaba de su honor, elemento ligado asimismo en el pensamiento político converso a la idea de virtud lograda a través de la noción de servicio público. También la Sentencia-Estatuto, al querer legitimar la segregación estaba quebrando la idea de una sociedad unitaria, esto es, por motivos de origen, estaba rompiendo la posibilidad tanto de una comunidad cristiana cohesionada como de una comunidad política unida: estaba anulando la posibilidad de una república, tanto civil como cristiana.

\footnotetext{
${ }^{329}$ El texto íntegro de la Sentencia-Estatuto está publicado en un anexo a la edición latina del Defensorium de Alonso (1943): 357-365. De ahí tomamos este fragmento.
} 
La densidad de reacciones a dicha Sentencia-Estatuto fue notable, y la sucesión de textos condenatorios con dicha medida y a favor de los conversos fue vertiginosa. Y uno de esos textos fue nuestro Defensorium unitatis chrsitianae. Los apologistas conversos como Cartagena, Fernán Díaz de Toledo, Lope Barrientos, Juan de Torquemada o Alonso de Oropesa no dudaban de la sinceridad de las mayoría de las conversiones (compara incluso Cartagena a los conversos con Job dado cuánto han de soportar la duda sobre sí). Como apuntamos ya anteriormente, nuestro obispo no renegó nunca de su ascendencia judía.

Haremos a continuación una breve enumeración de estos principales de escritos resultantes, ello con el fin de contextualizar al que atendemos, así como de mostrar cómo otros posteriores tienen una filiación en la obra de Cartagena. No entraremos en esta relación aún en detalles sobre el Defensorium, pero sí lo mencionaremos, pues realizamos dicha relación de acuerdo a un criterio cronológico.

- Defensorium unitatis chrsitianae, de Alonso de Cartagena. Redactado en verano de 1449 (de hecho, en el prólogo a esta obra hace referencia su autor a otro pequeño escrito previo al respecto, el cual, sin embargo, no conservamos). Su autor fue una de las primeras voces que se alzaron contra las medidas discriminatorias, las cuales cometían la peor de las herejías, esto es, romper la unidad de la cristiandad. Grosso modo, en un resumen superficial, podríamos decir que en este texto Cartagena vincula judaísmo y cristianismo causalmente, demuestra la unidad del género humano bajo la redención y desactiva jurídicamente la validez de los estatutos de limpieza de sangre (sobre todo discutiendo un decreto Judaei de Graciano que usaba también la Sentencia-Estatuto como argumento). Nuestro autor interpeló al rey y al Papa a que intercediesen por los conversos ante tamaña arbitrariedad y castigasen a sus promotores. No nos detendremos más ahora en un análisis profundo del Defensorium, ya que lo abordaremos un poco más adelante, pero sí reproducimos una cita de Cartagena acerca de la intencionalidad de su trabajo: «En aquella oportunidad en que me tomé la tarea de escribir estas cosas para aplastar en su mismo nacimiento el error que algunos se esforzaban por introducir, y del que nació el tratado (...) ha sido la flaqueza de mi pluma la que ha podido refutar lo que intentaba romper la 
indivisibilidad de la unidad cristiana ${ }^{330} \gg$.

- Bula Humani generi inimicus, redactada por el Papa Nicolás V (respondiendo seguramente a la petición de intercesión papal hecha por Cartagena en su Defensorium) ${ }^{331}$. Fue promulgada el 24 de septiembre de 1449, y reprobaba apologéticamente la segregación basándose en textos apostólicos y en fundamentos jurídicos. Asimismo, condenaba a excomunión de quienes negasen el acceso de nuevos miembros a la Iglesia - ya fueran judíos, musulmanes o gentiles - y a quienes dudasen de la sincera conversión a sus descendientes, así como a quienes impidiesen a los conversos el acceso a cargos civiles o religiosos. Pese a que esta bula fue efectiva en un inicio, ya en 1451 Nicolás V habría de volver a pronunciarse en los mismos términos.

- Francisco de Toledo, converso que era deán de Toledo durante el pogromo y que por ello tuvo que huir a Roma, escribió también una defensa del grupo converso que refutaba los argumentos de la sentencia; este texto no se conserva ${ }^{332}$.

- Instrucción del Relator para el obispo de Cuenca a favor de la nación hebrea, elaborada por el relator Fernán Díaz de Toledo en octubre de $1449^{333}$. Díaz de Toledo, cristiano nuevo, dirigía a Lope Barrientos, obispo de Cuenca y quien fue preceptor del príncipe Enrique IV, un texto en el que le requería se pronunciase en defensa de los conversos. Su crítica a la Sentencia-Estatuto estaba sedimentada en documentos pontificios como los cánones del Concilio de Basilea, así como en textos jurídicos como los de Graciano o las Partidas de Alfonso X el Sabio. Exponía, asimismo, que un numeroso porcentaje de la nobleza española tenía, en uno u otro grado de cercanía, ascendencia hebraica.

- Contra algunos zizañadores de la nación de los convertidos del pueblo de Israel, de Lope de Barrientos $^{334}$. Esta respuesta al texto del Relator, data también de octubre de 1449 y sigue la

\footnotetext{
${ }^{330}$ Cartagena (1993): 381.

${ }^{331}$ Puede consultarse íntegra en el apéndice de Alonso (1943) Intervención pontifica resolviendo la disputa. Alonso (1943): 367-370.

332 Tomamos este dato de Benito (2001).

${ }^{333}$ Puede consultarse íntegra en el apéndice de Alonso (1943) Instrucción del Relator para el obispo de Cuenca a favor de la nación hebrea. Alonso pp. 343-356.

${ }^{334}$ Puede consultarse íntegra en el apéndice de Alonso (1943) Instrucción del Relator para el obispo de Cuenca a favor de la nación hebrea. Alonso pp. 323-342.
} 
postura y la línea argumental de éste. Critica la paradoja de que se admita a los judíos en la Iglesia, para inmediatamente después de bautizarlos bloquearles el acceso a la vida pública.

- Memorial del Bachiller Marcos García de la Mora, conocido también como Marcos de Mazarambroz o, despectivamente, como Bachiller Marquillos, o Marquillos de Mazarambroz, de quien fuera asesor legal de Pedro Sarmiento (por lo que se cree que participó en la elaboración de la Sentencia-Estatuto) ${ }^{335}$. Probablemente a petición de Sarmiento redactó este Memorial con el fin de contraatacar la ola de textos doctrinales que demostraban la invalidez y dimensión herética de dicha Sentencia-Estatuto. La crítica estima que fue escrito a finales de octubre o principios de noviembre (pues poco después García de la Mora sería ajusticiado). Iba dirigido al Papa Nicolás V, cuya bula, recordemos, también había criticado con severidad la SentenciaEstatuto y había condenado a sus promotores. Del Memorial subyacía un patente antisemitismo que legitimaba el uso de la violencia contra los judíos («No solamente no es crimen, mas si así no fuera hecho, fuera crimen», asevera García de la Mora) y recogía la creencia popular de que éstos pretendían acabar con el cristianismo en Castilla, además, según el Memorial, los judíos tenía una naturaleza intrínsecamente maligna y ni siquiera el bautismo podía erradicarla, de ahí que los conversos, en incluso sus descendientes, la mantuviesen. Pese a las carencias argumentativas de este texto, hay que hacer notar que se volvería un referente años después en la consolidación de la ideología de la segregación y la exclusión por motivos de sangre que se iría imponiendo en Castilla. Como explica Eloy Benito «Ni teológica, ni jurídica, ni apologéticamente, la desaforada argumentación de Marcos García de Mora tiene apenas consistencia. Su valor radica en su propia existencia, como pieza ilustrativa del carácter y matiz de la rebelión toledana y el espíritu que informaba, en lo popular, la oposición de la época a los conversos. (...) Sorprendentemente, sin embargo, la torpe defensa de ésta por Marquillos de Mazarambroz iba a ser homologada ${ }^{336}$.

- Tractatus contra madianitas et ismaelitas adversarios et detractores filiorum qui de populo israelitico originem traxerunt de Juan de Torquemada (cardenal dominico que habitaba Roma

\footnotetext{
${ }^{335}$ Puede consultarse íntegro en Benito (2001).

${ }^{336}$ Benito (2001).
} 
como colaborador de Nicolás $\mathrm{V}$ y que sería tío del futuro inquisidor) ${ }^{337}$. Este autor se erigió como defensor de los conversos en el Vaticano y dicha obra de 1450 -que resulta un conmovedor alegato de tolerancia religiosa - rebatió mediante textos canónicos cada afirmación del Memorial de García de la Mora y ensalzó al pueblo judío, entre otras cosas, argumentando que Cristo lo era, así que sería herético afirmar una intrínseca vileza en los hebreos. En realidad, toda la humanidad en algún momento había sido infiel. Para Torquemada, igual que para Cartagena, como veremos, el judaísmo y el cristianismo estaban ligados por una relación causal, es decir, el judaísmo era una antesala, una preparación, para el cristianismo. Con la aparición de Cristo y su oferta de redención universal, se inauguraba una actitud de acogida en la fe, por ello, el que hubiera conversos era del todo lógico.

- Lumen ad revelationem gentium et gloriam plebis tuae Israel del jerónimo Alonso de Oropesa, terminada en 1465 y que es una sólida defensa de los conversos (de quienes, de hecho, sostiene esta obra, hay que admirar su gesto de conversión) y de la unidad de los cristianos como cuerpo místico de Cristo (ya nos referimos a este autor en el capítulo segundo de este trabajo al hablar del organicismo y el paulinismo) $)^{338}$.

En definitiva, muchos eclesiásticos e intelectuales —en realidad, la mayoría de los intelectuales del momento en Castilla, no olvidemos, además, que mucha de la clase pensante castellana era novocristiana- veían las medidas de exclusión contra los conversos como un flagrante asalto contra su dignidad, además de como una herejía, una arbitrariedad en el uso de la autoridad y una injusticia que no podía legitimarse de ningún modo cabal. Sin embargo, había quienes no opinaban lo mismo: sectores de las órdenes mendicantes jaleaban el hondo rechazo popular contra los judíos, y por ende, contra los conversos. En los años siguientes a 1449, la división social entre quienes defendían a los conversos y quienes los estigmatizaban se fue acentuando. Del lado antisemita, la obra más relevante es el Fortalitium Fidei de Alonso de Espina, escrita ya en 1458, aunque publicada cerca de una década después. En este solvente tratado su autor reflexionaba sobre los enemigos del cristianismo, e ilustraba a los predicadores sobre cómo prevenirlos, en salvaguarda de la fe. Uno de los enemigos de la fe, según Espina, era

\footnotetext{
${ }^{337}$ Puede consultarse en López y Proaño (eds.) (1957): Tractatus contra madianitas et ismaelitas (Defensa de los judíos conversos). Burgos, Ed. Hijos de S. Rodríguez.

${ }^{338}$ Véase al respecto Sicroff (1982).
} 
sin duda el judaísmo. Como decimos, el pulso popular era altamente antisemita (también como rechazo y revancha resentida al poder y riqueza que tradicionalmente los judíos habían tenido en Castilla, y a su celoso corporativismo), lo cual aumentó los actos violentos contra los judíos y las demandas sociales para que se inquiriese a quienes no eran verdaderos conversos y seguían profesando el judaísmo (justo a esto respondería unos años después la instauración de la Inquisición)

Esta atmósfera provocó que finalmente el rey Enrique IV de Castilla, que se había mantenido relativamente silente al respecto, cediese y aplicase en 1468 los estatutos de limpieza de sangre en Toledo y Ciudad Real, quedando ambas ciudades sin la posibilidad de que los conversos desempeñasen cargos públicos. Después dichas leyes discriminatorias se extenderían exponencialmente: más ciudades, consejos y órganos gubernamentales, gremios, centros educativos, cofradías, etc., las harían suyas. Dos décadas después de la Sentencia-Estatuto finalmente ésta se imponía: el germen de la exclusión se expandía, y, lo que es peor, se legitimaba moral y jurídicamente; lamentablemente, se enquistaría en la Historia de España. Aún habría voces críticas como la del arzobispo D. Alonso Carrillo en 1480 -quien influido por Oropesa, escribía en favor de los perseguidos en el Sínodo Diocesano reunido en Alcalá de Henares y daba por nulos este tipo de estatutos discriminatorios-, la de Hernando del Pulgar que protestó en 1482 por las leyes discriminatorias a los conversos de Guipúzcoa, la del prestigioso jurisconsulto Alonso Díaz de Montalvo, o años después hechos como la gran presencia e importancia de los conversos en la Compañía de Jesús.

Pero el pensamiento oficial fue otro, y la racionalidad inclusiva y el proyecto de convivencia que promovían los intelectuales conversos fueron anulados como proyecto político. El esfuerzo de estos intelectuales sería en vano en cuanto a su dimensión práctica, sin embargo - y esto es muy importante señalarlo - su impronta perduraría; y no sólo es que perviviese, es que se tornó rasgo constitutivo de lo que hemos descrito en este trabajo como pensamiento político converso. Las circunstancias de exclusión habían obligado a reflexionar acerca de la necesidad de conformar una comunidad política cohesionada, así como a revalorizar la importancia que tenía el poder ostentar cargos públicos como forma de participar en la vida civil y las formas que había de garantizar que esto no se le impidiese por defecto nadie. Obligaron a 
pensar sobre la inclusión, la libertad y la igualdad. Estos temas de reflexión eran cuestiones de hondo calado republicano, y ya las conocían como elaboración teórica estos pensadores conversos de la Castilla del XV, pero a ellos les tocó encarnar, abordar y adaptar estos temas no sólo desde la teoría, sino desde la propia experiencia de exclusión. Y abordar estos temas desde su necesario engranaje con la cuestión religiosa que había detonado el problema de fractura de la convivencia (además, para su interpretación del cristianismo, al que se habían sumado, éste coincidía con el pensamiento republicano en cuanto a estas ideas de vocación de comunidad fraterna universal). Lógicamente, estas vivencias hicieron que la forma de elaborar los principios republicanos para los pensadores castellanos tuviera una serie de especificidades, que son precisamente las que queremos visibilizar en esta tesis y las que caracterizan lo que hemos acunado como pensamiento político converso. Un pensamiento que tuvo a Cartagena como unos de sus líderes, y el Defensorium unitatis christianae como una de sus mejores materializaciones textuales, por ello vamos a analizar en seguida cómo se articularon estas ideas de inspiración republicana con el cristianismo en esta obra. Sin embargo, antes vamos a terminar este bloque descriptivo de presentación del Defensorium, resumiendo su contenido y haciendo un análisis de las autoridades que se aducen en el texto.

Explicado ya el origen del Defensorium unitatis chistianae, pasemos a resumir someramente su contenido por si el lector lo desconoce. Este tratado está escrito en latín y dirigido formalmente al rey Juan II de Castilla, tanto por su dedicatoria como por las apelaciones al mismo que se realizan a lo largo del texto. Sin embargo, también se infiere como interlocutor al Papa Nicolás V; el que la obra esté escrita en latín nos permite entrever en ella cierta vocación de difusión internacional. Su formato es claramente escolástico en su configuración discursiva, en su pulcro formalismo y en su constante referencia al criterio de autoridad.

Este tratado está dividido en tres partes. La primera consta de un prólogo laudatorio en el que le dirige el libro a Juan II y de diez capítulos en los que Cartagena quiere demostrar, vía autoridad bíblica, la unidad del género humano, unidad indiscutible dado su origen común bien probado en numerosas ocasiones en el Antiguo Testamento. También al lo largo esta primera decena de capítulos comienza ya por parte de nuestro autor la legitimación del pueblo judío con argumentos como el que éste posee un digno elenco en su historia de reyes y personajes que son 
ejemplo de virtud moral, o que este pueblo fue elegido y preparado para albergar al Mesías. Precisamente en torno a este hecho se articula el núcleo argumental de esta primera parte: Cristo trae la unidad entre pueblos, la consolida, no inaugura una artificial división entre judíos y cristianos, sino que los une causalmente y esencialmente. Lo veterotestamentario no es sino anuncio de lo neotestamentario (más adelante ahondaremos en todo esto).

La segunda parte de este tratado, encabezada de nuevo por un prólogo en el que alaba y clama al monarca, posee una estructura más complicada: se divide en cuatro teoremas, que se subdividen asimismo en capítulos, alcanzando un total de treinta y seis. El Teorema Primero, que consta de ocho capítulos, y en palabras del propio Cartagena «demuestra que por medio del redentor del mundo Jesucristo nuestro Señor, el pueblo israelita fue completamente redimido» ${ }^{339}$. El Teorema Segundo, éste de sólo tres capítulos, de nuevo en boca de su autor: «prueba que todo el mundo ha recibido la gracia de la salvación por medio del mismo Salvador y del mismo modo» ${ }^{340}$. Respecto al Teorema Tercero, subdividido en seis capítulos, dice nuestro obispo, que «demuestra que tanto los israelitas como los gentiles al entrar en la fe católica por la puerta del sagrado bautismo no persisten como dos pueblos o como dos linajes diferentes, sino que de los procedentes de un y otra parte se crea un pueblo nuevo»» ${ }^{341}$. El Teorema Cuarto, el más extenso con treinta y cuatro capítulos (que, desde el segundo al décimo, tienen tres sub-artículos), lo introduce el burgalés: «Continuación del cuarto teorema que hace ver cómo los que llegan a la fe católica, tanto de un lado como del otro, recobran y adquieren el derecho de conseguir de nuevo toda la superioridad, nobleza, u otros méritos que primeramente no tenían, con tal de que no vaya en contra de los principios de la jerarquía de la Iglesia» ${ }^{342}$. Los veintidós primeros capítulos prueban que, tras el bautismo, a los que lo reciben no puede arrebatárseles sus dignidades, derechos y oficios; los doce capítulos siguientes refutan y desactivan con impecable rigor jurídico las tesis con las que el Bachiller Marcos García de la Mora ('Bachiller Marquillos') pretende justificar sus estatutos de limpieza de sangre aplicables a los conversos.

\footnotetext{
${ }^{339}$ Cartagena (1993): 145.

${ }^{340}$ Cartagena (1993): 177.

${ }^{341}$ Cartagena (1993): 189.

${ }^{342}$ Cartagena (1993): 213.
} 
En la tercera parte del Defensorium, constituida por catorce capítulos y un ultílogo de cierre de nuevo dirigido al rey, su autor aporta al monarca soluciones para reprimir el caso histórico concreto que detonó esta obra — esto es, la rebelión de Toledo con su subsiguiente pogromo antijudío y anticonverso-, y se proponen remedios para su control. Además Cartagena expone cómo desde el punto de vista doctrinal las medidas de segregación promovidas por dichos estatutos son de clara naturaleza herética y, por tanto, interpela al rey y al Papa para que intervengan al respecto, y al hacer esta exhortación de paso, en las últimas páginas del texto, Cartagena expone ideas sobre teoría de gobierno y acerca de los deberes de la monarquía. 


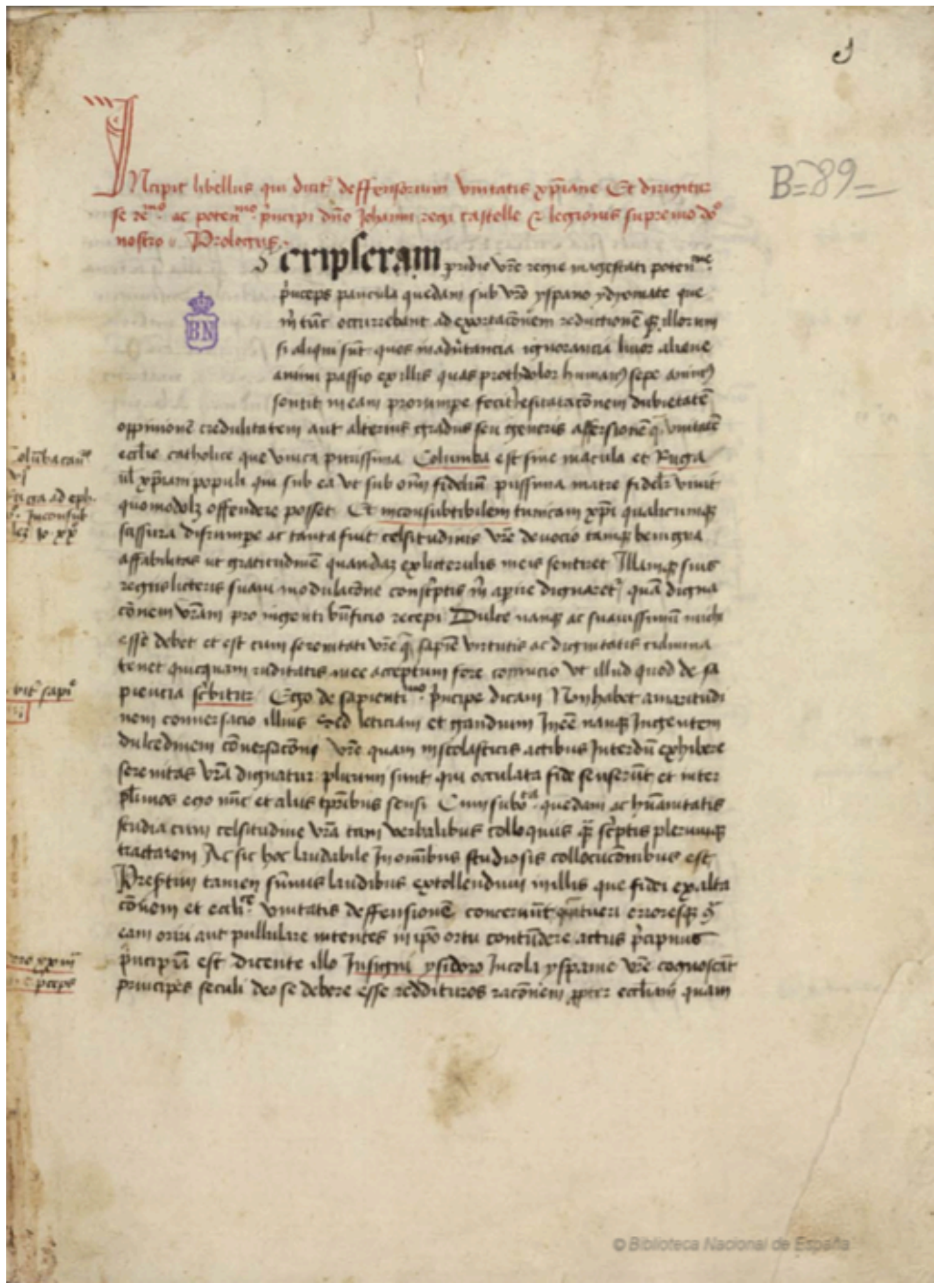

Imagen del manuscrito 442 de la Biblioteca Nacional de España (mss. 442) copia del Defensorium unitatis chrsitianae. 
Abordar la cuestión de las autoridades citadas en esta obra no es un puro formalismo erudito, sino una útil información para conocer las fuentes que empleó el autor, lo que nos da pistas de su pensamiento, y algo que incluso cobra más relevancia al estar ante un texto de formato escolástico el cual, por ello mismo, constantemente remite al criterio de autoridad. De ahí que señalemos a continuación en la siguiente lista las autoridades referidas por Cartagena y cuántas veces lo hace con cada una (conviene aclarar que, como era usual en la época, Cartagena no siempre cita textualmente, sino las más veces parafrasea o tan sólo refleja cómo determinada autoridad comparte y sustenta con su peso lo que él está aseverando). Ponemos en nota al pie las páginas del Defensorium donde dichas autoridades son aludidas.

Fuentes bíblicas:

- Génesis citado 26 veces $^{343}$.

- Éxodo citado 3 veces ${ }^{344}$.

- Números citado 5 veces $^{345}$.

- Deuteronomio citado 10 veces $^{346}$.

- Josué citado $1 \mathrm{vez}^{347}$.

- Ruth citado 2 veces ${ }^{348}$.

- Libro Primero de los Reyes 17 veces $^{349}$.

- Libro Segundo de los Reyes citado 13 veces ${ }^{350}$.

${ }^{343}$ En la edición de Alonso (1943) en págs. 65, 66, 67, 68, 69, 70, 88, 109, 120,122, 149, 150, 158, 167, у 186.

${ }^{344}$ En la edición de Alonso (1943) en págs. 81, 298, y 299.

${ }^{345}$ En la edición de Alonso (1943) en págs. 77, 78, 101 y 162.

${ }^{346}$ En la edición de Alonso (1943) en págs. 72, 73, 74, 75, 95, 100, 101 y 162.

${ }^{347}$ En la edición de Alonso (1943) en pág. 132.

${ }^{348}$ En la edición de Alonso (1943) en págs. 124 y 132.

${ }^{349}$ En la edición de Alonso (1943) en págs. 158, 159, 162, 210, 221, 269, 275, 279, 281, 282 y 300. 
- Judith citado 1 vez ${ }^{351}$.

- Libro Primero de los Macabeos citado 2 veces ${ }^{352}$.

- Job citado 8 veces ${ }^{353}$.

- Salmos citado 30 veces $^{354}$.

- Proverbios citado 3 veces ${ }^{355}$.

- Eclesiastés citado 2 veces ${ }^{356}$.

- Cantar de los Cantares citado 3 veces ${ }^{357}$.

- Libro de la Sabiduría citado 4 veces ${ }^{358}$.

- Eclesiástico citado $1 \mathrm{vez}{ }^{359}$.

- Isaías citado 34 veces ${ }^{360}$.

- Jeremías citado 6 veces $^{361}$.

${ }^{350}$ En la edición de Alonso (1943) en págs. 128, 158, 159, 280, 282, 283 y 285.

${ }^{351}$ En la edición de Alonso (1943) en pág. 68.

${ }^{352}$ En la edición de Alonso (1943) en pág. 164.

${ }^{353}$ En la edición de Alonso (1943) en págs. 71, 250, 251, 252 y 253.

${ }^{354}$ En la edición de Alonso (1943) en págs. 64, 72, 75, 85, 88, 89, 104, 107,123, 126, 134, 137, 141, 144, 145, 149, $198,220,235,237,269,279$ y 317.

${ }^{355}$ En la edición de Alonso (1943) en págs. 115, 271 y 297.

${ }^{356}$ En la edición de Alonso (1943) en págs. 82 y 254.

${ }^{357}$ En la edición de Alonso (1943) en págs. 61, 197 y 273.

${ }^{358}$ En la edición de Alonso (1943) en págs. 62, 66, 166 y 251.

${ }^{359}$ En la edición de Alonso (1943) en pág. 64.

${ }^{360}$ En la edición de Alonso (1943) en págs. 75, 80, 81, 87, 88, 95, 99, 100, 101, 103, 104, 122, 129, 135, 136, 140, $141,142,155,161,162,221,223,269$ y 290.

${ }^{361}$ En la edición de Alonso (1943) en págs. 71, 95, 101, 123 y 276. 
- Baruch citado 1 vez ${ }^{362}$.

- Ezequiel citado 10 veces $^{363}$.

- Oseas citado 3 veces ${ }^{364}$.

- Amós citado 1 vez ${ }^{365}$.

- Habacuc citado $1 \mathrm{vez}^{366}$.

- Zacarías citado 3 veces ${ }^{367}$.

- Malaquías citado 8 veces $^{368}$.

- Evangelio según San Mateo citado 22 veces $^{369}$.

- Evangelio según San Marcos citado 4 veces ${ }^{370}$.

- Evangelio según San Lucas citado 21 veces $^{371}$.

- Evangelio según San Juan citado 40 veces $^{372}$.

- Hechos de los Apóstoles citado 15 veces $^{373}$.

${ }^{362}$ En la edición de Alonso (1943) en pág. 299.

${ }^{363}$ En la edición de Alonso (1943) en págs. 98, 100, 107, 138, 187, 188, 189 y 300.

${ }^{364}$ En la edición de Alonso (1943) en págs. 102, 237, 291.

${ }^{365}$ En la edición de Alonso (1943) en pág. 74.

${ }^{366}$ En la edición de Alonso (1943) en pág. 144.

${ }^{367}$ En la edición de Alonso (1943) en págs. 98, 122 y 138.

${ }^{368}$ En la edición de Alonso (1943) en págs. 70, 71, 98, 204, 205, 211, 213 y 223.

${ }^{369}$ En la edición de Alonso (1943) en págs. 63, 65, 78, 79, 86, 93, 95, 96, 99, 108, 110, 128, 147, 167, 183 y 292.

${ }^{370}$ En la edición de Alonso (1943) en págs. 87, 121 y 162.

${ }^{371}$ En la edición de Alonso (1943) en págs. 63, 84, 96, 97, 98, 107, 122, 124, 125, 143, 144, 166, 167, 221 y 292.

${ }^{372}$ En la edición de Alonso (1943) en págs. 61, 78, 86, 89, 107, 108, 118, 139, 140, 142, 145, 166, 197, 236, 279 y 291.

${ }^{373}$ En la edición de Alonso (1943) en págs. 86, 88, 97, 111, 127, 162, 168, 202 y 205. 
- Carta a los Romanos citado 24 veces ${ }^{374}$.

- Primera carta a los Corintios citado 12 veces $^{375}$.

- Segunda carta a los Corintios citado $1 \mathrm{vez}^{376}$.

- Carta a los Gálatas citado 15 veces ${ }^{377}$.

- Carta a los Efesios citado 7 veces ${ }^{378}$.

- Carta a los Filipenses citado 3 veces ${ }^{379}$.

- Carta a los Colosenses citado $1 \mathrm{vez}^{380}$.

- Primera carta a Timoteo citado 3 veces ${ }^{381}$.

- Carta a los Tito citado $1 \mathrm{vez}^{382}$.

- Epístola a los Hebreos citado 6 veces ${ }^{383}$.

- Primera Epístola de San Pedro citado 3 veces ${ }^{384}$.

- Primera Epístola de San Juan citado 2 veces $^{385}$.

\footnotetext{
${ }^{374}$ En la edición de Alonso (1943) en págs. 63, 70, 74, 77, 90, 97, 98, 104, 105, 106, 109, 116, 117, 118, 126, 150, 183,251 y 276.

${ }^{375}$ En la edición de Alonso (1943) en págs. 80, 91, 125, 143, 185, 251, 257, 265, 290 y 318.

${ }^{376}$ En la edición de Alonso (1943) en pág. 99.

${ }^{377}$ En la edición de Alonso (1943) en págs. 74, 77, 89, 90, 115, 117, 167, 168, 170, 172, 198 y 200.

${ }^{378}$ En la edición de Alonso (1943) en págs. 61, 145, 190, 196, 198, 199 y 235.

${ }^{379}$ En la edición de Alonso (1943) en págs. 117 y 230.

${ }^{380}$ En la edición de Alonso (1943) en pág. 77.

${ }^{381}$ En la edición de Alonso (1943) en págs. 66, 245 y 247.

${ }^{382}$ En la edición de Alonso (1943) en pág. 110.

${ }^{383}$ En la edición de Alonso (1943) en págs. 84, 116, 132, 134, 142, y 166.

${ }^{384}$ En la edición de Alonso (1943) en págs. 74, 163 y 184.
} 
- Apocalipsis citado 8 veces ${ }^{386}$.

Autoridades citadas:

- Agustín, San: citado 31 veces. ${ }^{387}$

- Alberto Magno, San: citado 1 vez $^{388}$.

- Alejandro, Papa: citado $1 \mathrm{vez}^{389}$.

- Alejandro III, Papa: citado 1 vez ${ }^{390}$.

- Alfonso X el Sabio (las Partidas): citado 2 veces ${ }^{391}$.

- Anacleto, Papa: citado 2 veces ${ }^{392}$.

- Ambrosio, San: citado 5 veces ${ }^{393}$.

- Aristóteles: citado 12 veces ${ }^{394}$.

- Baysio, Guido de: citado 1 vez ${ }^{395}$.

- Beda el Venerable, San: citado 2 veces ${ }^{396}$.

${ }^{385}$ En la edición de Alonso (1943) en págs. 236 y 298.

${ }^{386}$ En la edición de Alonso (1943) en págs. 91, 98, 129, 149, 163 y 300.

${ }^{387}$ la edición de Alonso (1943) en págs. 65, 66, 69, 71, 79, 89, 102, 108, 109, 112, 136, 146, 157, 176, 184, 189, 190, 191, 192, 123, 197, 236, 239, 248, 272, 273, 283, 284, 285 у 296.

${ }^{388}$ En la edición de Alonso (1943) en pág. 202.

${ }^{389}$ En la edición de Alonso (1943) en pág. 298.

${ }^{390}$ En la edición de Alonso (1943) en pág. 192.

${ }^{391}$ En la edición de Alonso (1943) en págs. 206 y 207.

${ }^{392}$ En la edición de Alonso (1943) en págs. 157 y 298.

${ }^{393}$ En la edición de Alonso (1943) en págs. 119133134245 y 247.

${ }^{394}$ En la edición de Alonso (1943) en págs. 8085113114115171175202217226250 y 289.

${ }^{395}$ En la edición de Alonso (1943) en pág. 240. 
- Cicerón citado $1 \mathrm{vez}^{397}$.

- Concilio de Basilea: citado 1 vez ${ }^{398}$.

- Concilio de Toledo IV: citado 6 veces ${ }^{399}$.

- Comentadores de Aristóteles: citado 1 vez ${ }^{400}$.

- Cromacio, San: citado 1 vez $^{401}$.

- Corpus Iuris Civilis (casi siempre se cita el Digesto, se incluye aquí a diversos jurisconsultos): citado 24 veces $^{402}$.

- Demóstenes: citado 1 vez ${ }^{403}$.

- Dionisio Aeropagita: citado $1 \mathrm{vez}^{404}$.

- Doctores: citado 4 veces ${ }^{405}$.

- Doctores de la Iglesia (Doctores, Santos): citado 8 veces ${ }^{406}$.

- Durantis, Guillermo: citado 1 vez ${ }^{407}$.

${ }^{396}$ En la edición de Alonso (1943) en págs. 65 y 143.

${ }^{397}$ En la edición de Alonso (1943) en pág. 202.

${ }^{398}$ En la edición de Alonso (1943) en pág. 196.

${ }^{399}$ En la edición de Alonso (1943) en págs. 232, 233, 234, 240 y 260.

${ }^{400}$ En la edición de Alonso (1943) en pág. 172.

${ }^{401}$ En la edición de Alonso (1943) en pág. 128.

${ }^{402}$ En la edición de Alonso (1943) en págs. 118, 125, 160, 185, 186, 188, 193, 211, 213, 221, 222, 228, 236, 240, 242, 246, 264, 256274, 275, 302, 303 y 304.

${ }^{403}$ En la edición de Alonso (1943) en pág. 149.

${ }^{404}$ En la edición de Alonso (1943) en pág. 84.

${ }^{405}$ En la edición de Alonso (1943) en págs. 104, 119, 139 y 185.

${ }^{406}$ En la edición de Alonso (1943) en págs. 71, 79, 119, 125, 135, 139, 143 у 185.

${ }^{407}$ En la edición de Alonso (1943) en pág. 218. 
- Enrique III de Castilla: citado 1 vez ${ }^{408}$.

- Fuero Juzgo: citado 5 veces ${ }^{409}$.

- Fulgencio de Ruspe: citado 1 vez ${ }^{410}$.

- Gayo (jurisconsulto, vía Corpus Iuris Civilis): citado 1 vez ${ }^{411}$.

- García de Campos, Diego: citado 1 vez ${ }^{412}$.

- Gelasio, Papa: citado 1 vez ${ }^{413}$.

- Glosa Ordinaria: citado 5 veces ${ }^{414}$.

- Graciano: citado 25 veces $^{415}$.

- Gregorio Magno, San: citado 8 veces ${ }^{416}$.

- Gregorio IX, Papa (vía Corpus Iuris Canonicis): citado 4 veces $^{417}$.

- Historia Tripartita: citado $1 \mathrm{vez}^{418}$.

- Inocencio III, Papa: citado 4 veces ${ }^{419}$.

${ }^{408}$ En la edición de Alonso (1943) en pág. 207.

${ }^{409}$ En la edición de Alonso (1943) en págs. 259, 260, 261, 262 y 265.

${ }^{410}$ En la edición de Alonso (1943) en pág. 196.

${ }^{411}$ En la edición de Alonso (1943) en pág. 174.

${ }^{412}$ En la edición de Alonso (1943) en pág. 91.

${ }^{413}$ En la edición de Alonso (1943) en pág. 246.

${ }^{414}$ En la edición de Alonso (1943) en págs. 112, 119, 198, 199 y 200.

${ }^{415}$ En la edición de Alonso (1943) en págs. 17, 61, 62, 69, 81, 90, 91, 108, 109, 110, 128, 146, 155, 157, 191, 227 $229,232,233,234,244$ y 257.

${ }^{416}$ En la edición de Alonso (1943) en págs. 109, 119, 145, 182, 244, 246, 254 y 256.

${ }^{417}$ En la edición de Alonso (1943) en págs. 179, 180, 243 y 258.

${ }^{418}$ En la edición de Alonso (1943) en pág. 155. 
- Isidoro, San: citado 9 veces ${ }^{420}$.

- Jerónimo, San: citado 14 veces $^{421}$.

- Jiménez de Rada, Rodrigo: citado 2 veces ${ }^{422}$.

- Josefo: citado 1 vez $^{423}$.

- Juan XXII, Papa: citado $1 \mathrm{vez}^{424}$.

- Juan II, rey de Castilla: citado $1 \mathrm{vez}^{425}$.

- Juan Anania (¿?): citado $1 \mathrm{vez}^{426}$.

- Juan Andrés (¿?): citado $1 \mathrm{vez}^{427}$.

- Juan Crisóstomo, San: citado 2 veces ${ }^{428}$.

- Juan Teutónico: citado 8 veces ${ }^{429}$.

- Julio, Papa: citado 2 veces $^{430}$.

- Marcelo: citado $1 \mathrm{vez}^{431}$.

${ }^{419}$ En la edición de Alonso (1943) en págs. 179, 186, 257 y 258.

${ }^{420}$ En la edición de Alonso (1943) en págs. 62, 106, 107, 146, 230, 264 y 266.

${ }^{421}$ En la edición de Alonso (1943) en págs. 76, 90, 104, 128, 132, 139, 181, 183, 216, 249, 272, 273, 289 y316.

${ }^{422}$ En la edición de Alonso (1943) en págs. 229 y 230.

${ }^{423}$ En la edición de Alonso (1943) en pág. 165.

${ }^{424}$ En la edición de Alonso (1943) en pág. 267.

${ }^{425}$ En la edición de Alonso (1943) en pág. 208.

${ }^{426}$ En la edición de Alonso (1943) en pág. 222.

${ }^{427}$ En la edición de Alonso (1943) en pág. 222.

${ }^{428}$ En la edición de Alonso (1943) en págs. 128 y 194.

${ }^{429}$ En la edición de Alonso (1943) en págs. 91, 240, 241, 242, 243, 255 y 273.

${ }^{430}$ En la edición de Alonso (1943) en págs. 2677292. 
- Martín, Papa San: citado $1 \mathrm{vez}^{432}$.

- Martín de Braga, San: citado 1 vez ${ }^{433}$.

- Nicolás de Lira: citado 1 vez ${ }^{434}$.

- Orígenes: citado 2 veces ${ }^{435}$.

- Panormitanus: citado $1 \mathrm{vez}^{436}$.

- Pedro Comestor: citado 3 veces ${ }^{437}$.

- Pedro Lombardo citado $1 \mathrm{vez}^{438}$.

- Pitágoras: citado $1 \mathrm{vez}^{439}$.

- Platón: citado 2 veces ${ }^{440}$.

- Pompeyo: citado $1 \mathrm{vez}^{441}$.

- Pontifical Romano: citado $1 \mathrm{vez}^{442}$.

- Pseudo Dionisio: citado $1 \mathrm{vez}^{443}$.

${ }^{431}$ En la edición de Alonso (1943) en pág. 303.

${ }^{432}$ En la edición de Alonso (1943) en pág. 146.

${ }^{433}$ En la edición de Alonso (1943) en pág. 146.

${ }^{434}$ En la edición de Alonso (1943) en pág. 159.

${ }^{435}$ En la edición de Alonso (1943) en págs. 77 y 133.

${ }^{436}$ En la edición de Alonso (1943) en pág. 192.

${ }^{437}$ En la edición de Alonso (1943) en págs. 159, 165 y 280.

${ }^{438}$ En la edición de Alonso (1943) en pág. 71.

${ }^{439}$ En la edición de Alonso (1943) en pág. 80.

${ }^{440}$ En la edición de Alonso (1943) en págs. 80 y 113.

${ }^{441}$ En la edición de Alonso (1943) en pág. 303.

${ }^{442}$ En la edición de Alonso (1943) en pág. 205. 
- Rábano Mauro (vía Graciano): citado 1 vez ${ }^{444}$.

- Sixto II, Papa: citado 1 vez $^{445}$.

- Tomás de Aquino, Santo: citado 13 veces $^{446}$.

- Ulpiano (jurisconsulto, vía Corpus Iuris Civilis): citado 2 veces ${ }^{447}$.

- Urbano, Papa: citado 1 vez $^{448}$.

- Varo: citado $1 \mathrm{vez}^{449}$.

- Zenón: citado $1 \mathrm{vez}^{450}$.

Basándonos en la relación de arriba, podemos afirmar que lo más destacable es la presencia bíblica, básicamente veterotestamentaria, al igual que exponentes de la patrística y la literatura canónica y conciliar, primando San Agustín y Santo Tomás. Asimismo, la presencia de fuentes jurídicas es muy abundante, sobresaliendo el Corpus Iuris Civilis (ante todo el Digesto) y Graciano, como principal autoridad del Derecho Canónico. De todos modos, cabe resaltar la variedad de las fuentes de Cartagena, pues también autoridades de origen clásico como Aristóteles tiene su importante cabida, o fuentes hispánicas como Isidoro de Sevilla. Aunque el esfuerzo doctrinal de Cartagena se sedimente aún en textos tradicionales, de todo el Defensorium emana una sensibilidad de integrar fuentes de distintas disciplinas y épocas.

\footnotetext{
${ }^{443}$ En la edición de Alonso (1943) en pág. 81.

${ }^{444}$ En la edición de Alonso (1943) en pág. 110.

445 En la edición de Alonso (1943) en pág. 292.

${ }^{446}$ En la edición de Alonso (1943) en págs. 73, 83, 84, 143, 209, 220, 241, 249, 289, 290, 306, 309 y 310 ).

${ }^{447}$ En la edición de Alonso (1943) en pág. 173.

${ }^{448}$ En la edición de Alonso (1943) en pág. 292.

${ }^{449}$ En la edición de Alonso (1943) en pág. 393.

${ }^{450}$ En la edición de Alonso (1943) en pág. 80.
} 


\subsection{El valor del Defensorium.}

Tal y como hicimos notar arriba, el Defensorium unitatis chistianae fue mucho más que una 'obra de circunstancia' que se posicionaba ante un problema puntual, más que una apología de los cristianos nuevos y más que una exaltación del monarca para defenderlo del motín contra él (pese a que este aspecto haya sido el más estudiado del Defensorium - ya que en esta obra hay un tono de exaltación del monarca, algo comprensible dada la necesidad propagandística de ensalzar al rey tras una revuelta contra él—, no vamos a centrar nuestro análisis en ello). El Defensorium fue un texto crucial en un determinante espacio de conflicto para Castilla como fue la llamada 'cuestión conversa'. El experto en Cartagena, Luis Fernández Gallardo, que habla de una «construcción dialéctica del Defensorium», estima que este texto «es la obra maestra de los escritos pro-conversos y constituye la más acabada elaboración de los argumentos jurídicos y teológicos contra la discriminación e inhabilitación de los cristianos nuevos» ${ }^{451}$.

Pero nuestro texto fue incluso más que eso: sostenemos que supone todo un tratado de teología política que articula elementos cristianos con elementos republicanos, que propone un programa de convivencia y reconciliación basado en una ratio política inclusiva, que aplica la idea de universalismo paulino y de organicismo místico, que desactiva teológica y jurídicamente la posibilidad de segregación por esencialismo de origen, y que conforma un nuevo ethos cristiano en el que la teleología de la virtud cívica y la de la salvación confluyen. En definitiva, el Defensorium condensa paradigmáticamente lo que venimos describiendo como pensamiento político converso. Subyace por tanto de nuestro texto toda una estela filosófica, resultando un sugerente elemento para estudiar la filosofía política en el Renacimiento hispánico. Además, en este tratado cristalizaba gran parte del pensamiento de Cartagena que introdujimos en el capítulo previo.

Coincide con nuestro enfoque José Luis Villacañas, el cual sostiene que esta obra es uno de los pilares del programa político de lo que él llama la «nación de cristiano nuevos», acerca de lo cual tratamos ya en el capítulo segundo al explicar cómo el pensamiento converso implicaba también una traductibilidad práctica, esto es, un proyecto político, teológico y cultural desde el

\footnotetext{
${ }^{451}$ Fernández Gallardo (2002): 244, 245.
} 
que organizar la difícil convivencia y promover la participación cívica ${ }^{452}$. Por su parte, y en la misma dirección, los investigadores colombianos Juan Cárdenas y Enver Torregroza aseveran que «Cartagena responde a la demanda de una nueva interpretación del cristianismo frente a los desafíos que amenazan su propia unidad, a la vez que responde a la interna necesidad de una actualización dogmática que asegure su existencia como respuesta válida a las nuevas realidades políticas propias de aquello que entendemos por modernidad ${ }^{453}$. En otras palabras viene a decir lo mismo el profesor Fernando Miguel Pérez Herranz, para quien el Defensorium «(...) configurará un programa a favor del cristianismo, cuyo fin coincide con el de la humanidad toda: la constitución de una comunidad fuertemente unida por los lazos del amor —charitas $\longrightarrow{ }^{454}$. Y añadimos a esta cita que dicha comunidad unida místicamente por la ética del amor y de la charitas, además de ser comunidad cristiana, para Cartagena es y debe ser comunidad política: una comunidad en la cual la participación de los ciudadanos en el vivere civile en pro del bien común — con la subsiguiente conformación de comunidad política — contribuirá a fortalecer los lazos de unión de la comunidad cristina. República cívica y república cristiana se complementan. Pensemos en el daño que debió de suponer para este autor, y para toda la intelectualidad conversa castellana que se regía por esta visión, la prohibición a los conversos de la posibilidad de ostentar ningún cargo público, esto es, de ejercer su vocación de participación cívica y servicio público (que, como vimos en el capítulo anterior, era una noción fundamental para alcanzar la virtud).

El uso de la noción de pueblo que atraviesa esta obra, no sólo bebe de la idea de pueblo al modo tradicional mesiánico de la teología hebrea, sino también en este sentido de comunidad cohesionada como cuerpo político. En un pliegue republicano, lo que centra la teología política de Cartagena (con el Defensorium unitatis christianae como epítome) es la idea de un pueblo que es potencialmente ciudadanía, y que deviene ciudadanía precisamente vía una instrumentalización de elementos religiosos — principalmente el bautismo- que se tornan herramientas de dignificación y posibilidad de participación en el vivere civile. Es a través de la religión como Cartagena quiere implementar una ratio de la inclusión y la cohesión, esto es, su defensa de la unión de los cristianos es también defensa de la conformación de base comunitaria,

\footnotetext{
${ }^{452}$ Villacañas (2008): 532.

${ }^{453}$ Cárdenas y Torregroza (201): 11.

${ }^{454}$ Pérez Herranz (2016): 286.
} 
de comunidad política solidaria y participativa frente a la ratio de la exclusión y la dominación que se estaba imponiendo en la Modernidad hispánica.

Otro valor del Defensorium es que resulta una sugerente pieza de transición epocal en la que están conjugados elementos escolásticos y construcciones ideológicas medievales junto con rasgos de teoría política de cariz pre-moderno en una armónica filiación. Estimamos conveniente reproducir las palabras de su traductor, Guillermo Verdín-Díaz que nos arenga a no abordar una lectura reduccionista de este texto influidos por su formato y dejes escolásticos. Dice en la introducción a su traducción ${ }^{455}$ :

A primera vista podría pensarse que el Defensorium unitatis chistianae por el título y las circunstancias en que nació seguiría unas directrices de eclesiástico conservadurismo tradicional, receloso de los pujantes estudios humanistas, sin embargo (...) los estudios humanistas no constituyen para Cartagena una fuente de injerencias y de doctrinas nocivas para el pensamiento cristiano, sino una fuente de conocimientos muy valiosa en torno a la vida práctica y a las virtudes humanas por lo que supone de inquietud racional en la búsqueda de la perfección moral del individuo en sí mismo y en las relaciones con los demás.

Nos parece importante incidir en que hemos de hacer una lectura del Defensorium no sólo en clave canónica y doctrinal, sino abordar una lectura más profunda, decapar y detenernos en su filosofía política. De ahí que propongamos como una de las contribuciones de esta investigación el leerlo en clave republicana. De hecho, como podemos deducir del análisis de fuentes que mostramos antes, el texto que nos ocupa está cuajado de elementos del derecho civil y de la filosofía clásica. Coincide con esta visión el académico Enver Torregroza, quien hablando de la intencionalidad de esta obra, asevera que, de fondo, «Cartagena quiere sentar principios jurídicos, tesis teológicas y formular también argumentos propios de la filosofía política. La rebelión de Toledo fue un motivo propicio para ello» ${ }^{456}$.

\footnotetext{
${ }^{455}$ Verdín-Díaz (1993): 85. Corresponderán esta edición todas las citas que tomaremos de la traducción castellana del Defensorium Unitatis Christianae, y cuya referencia en notas al pie pondremos como «Cartagena (1993): » y la página correspondiente a continuación. Recordemos que esta traducción se basa en los siguientes manuscritos del Defensorium Unitatis Christianae: Biblioteca Nacional de Madrid, Ms. 422 y Biblioteca de la Universidad de Salamanca, Ms. 2070.

${ }^{456}$ Torregroza (2010): 183-184.
} 
Es precisamente su capacidad de articulación una de las mayores virtudes de este escrito: no sólo es que hibride teoría política bajomedieval con teoría política renacentista, sino, y esto es lo más importante, combina conceptos teológicos con rasgos de esta teoría política renacentista, esto es, con aportes del republicanismo, en una traductibilidad de enorme interés y que entendemos como el rasgo principal intrínseco al pensamiento político converso castellano, del cual Cartagena es uno de los máximos exponentes. Este es el rasgo que más queremos destacar de esta obra y el principal aporte de esta investigación. En un pliegue de realismo político, Cartagena quiso elaborar las bases de una ratio de la inclusión que permitiera en la Castilla del cuatrocientos la convivencia armoniosa y la consolidación de una base comunitaria que pudiera ser comunidad política. Sin embargo, como hemos comentado, la ratio de la exclusión y la dominación es la que finalmente se impuso y catalizó ciertas particularidades políticas de la modernidad hispánica. El pensamiento de Cartagena quedó marginado por el pensamiento oficial (aunque no su impronta, que se mantendría viva y se reproduciría — sobre todo entre pensadores, juristas, teólogos, profesores, literatos y ciertas órdenes religiosas como jerónimos o jesuitasaun sin ser asumida y nombrada per se como herencia de Cartagena): no parece casual que el Defensorium no volviera a editarse desde el siglo XVI hasta 1943, o que no se tradujera hasta 1993. Que la primera traducción a una accesible lengua romance de un texto que fue crucial en su momento se haya realizado pasados cinco siglos y medio da que pensar.

Por todo lo anterior nuestro acercamiento y voluntad de puesta en valor del Defensorium pivota sobre todo en torno a su teología política (resultante del binomio cristianismo + pensamiento republicano). Y por ello contextualizamos intelectualmente esta obra como una pieza clave del pensamiento político converso castellano del siglo XV. La entendemos desde su raigambre conversa y destacamos sus rasgos republicanos, los cuales, repetimos — tal y como insistimos ya en los Capítulos 1 y 2 - no son para nada excluyentes con una filosofía de la historia escatológica y con el apoyo a la institución monárquica. Respecto a esto último quepa aclarar que si bien Cartagena pareciera apoyar en ocasiones un intervencionismo estatal activo en pro de la conversión y una concepción del monarca como vicario de Cristo, esto ni implica, ni cimenta, su teología política en una teología imperial absolutista basada en un enfoque teocrático del rey (esta cuestión ya también la hemos visto en el Capítulo 3). 
En el colosal Defensorium unitatis chrsitianae, nuestro autor realiza una sugerente revisión de la relación entre judaísmo y cristianismo proponiendo su causalidad, es decir, la filiación y entre judaísmo y cristianismo, y, del mismo modo, realiza una revisión de la temporalidad de la Historia y de la salvación, planteando una nueva temporalidad mesiánica. En este propósito de argumentar esa necesaria inclusión y unidad —encarnaciones del universalismo paulino - hace uso de la metáfora organicista, empleada también por las teorías del principado y por el erasmismo para justificar planteamientos de igualdad y de cohesión del orbe cristiano. Asimismo, Cartagena demostrará la incorrección jurídica de leyes segregacionistas como los estatutos de limpieza de sangre basándose en sus errores formales de base, sus incongruencias y sus distorsiones diacrónicas. Tomará nuestro obispo elementos del republicanismo clásico en su argumentación teológico-política de acceso a la república cristiana. Y viceversa, tomará elementos religiosos como garantes del acceso a la ciudadanía y al honor, para poder así participar en la vida pública: así la instrumentalización de nociones como la gracia, la redención o el bautismo como 'salvoconductos' para el acceso a la ciudadanía y la participación y para la superación de esencialismos de origen. Justamente este engarce es lo más definitorio y sugerente para nosotros en Cartagena y lo que, según nuestro criterio, se torna rasgo un rasgo fundamental del pensamiento político converso. En los siguientes apartados iremos desgranando cómo hace todo esto, basándonos en el propio texto.

\subsection{Revisión teológico-histórica de la relación entre judaísmo y cristianismo. Creación de un nuevo pueblo a través de la revelación.}

Estamos con el Defensorium ante una sugerente revisión de la narración teológica de la Historia (siempre bajo una Filosofía de la Historia escatológica), revisión que asume el cristianismo como una culminación del judaísmo, y en lugar de escindir y contraponer ambos los liga causalmente, desembocando ambos en la temporalidad de la salvación. La Ley judía, esto es, el Antiguo Testamento no es sino una preparación ética para la verdadera salvación que llega con Cristo y el Evangelio. No ve Cartagena una cesura entre lo veterotestamentario y lo neotestamentario, aquél tiene anticipos proféticos constantes de éste. Como hemos apuntado anteriormente, Cartagena nunca renegó de sus orígenes judíos, pues para él la conversión al cristianismo de un judío era un proceso lógico dada esta comprensión del judaísmo como una preparación para el cristianismo. 
Además, Cartagena, al igual que lo había hecho Tomás de Aquino, entendía que el pueblo de Israel que retrata el Antiguo Testamento constituyó unas suerte de primera Iglesia, pues su sociedad estaba configurada alrededor de la idea de culto a Dios.

Alonso de Cartagena repiensa, asimismo, la noción de pueblo elegido del judaísmo al indicar que se eligió a este pueblo no porque fuera inherentemente más apto que otro, sino porque Dios necesitaba encarnarse y había de elegir un pueblo al que preparar, de ahí que dotase a los judíos de la Ley (el Antiguo Testamento), que los une al Mesías históricamente. Sin embargo, como decimos, esto no los hace más aptos para la salvación: ésta es igual para todos, porque lo que la posibilita es la Revelación, la venida y el amor de Cristo, y éstos son universales. El advenimiento de Cristo y el bautismo - como suerte de fenomenología renovada, como materialización de la gracia y la redención - propician una nueva temporalidad histórica, pues son fundacionales de un nuevo pueblo y de un nuevo tiempo, de una nueva historicidad. La llegada del cristianismo supone no una ruptura con la promesa del judaísmo, sino que supone una aceleración de la salvación, una suerte de «economía de la salvación» ${ }^{457}$. Como explica Villacañas, para los judíos este nuevo tiempo tiene un continuum en la Ley, para los gentiles, el bautismo inaugura esta temporalidad por completo, pero, en cualquier caso, lo importante es que el bautismo permite crear un nuevo pueblo, que es un unicus populus ${ }^{458}$. Cristo acelera la redención con el fin de unir al género humano en un solo pueblo. Además, la revelación es universal, es para todos - aquí nos encontramos con Pablo de nuevo-y debe materializarse en lo político, esto es, la revelación no es sólo contrafactual ni escatológica, sino que ha de conformar pueblo cristiano, república cristiana, communitas cristiana que sea también comunidad política unida y activa, entroncando en esto Cartagena con el realismo político del republicanismo renacentista. Sólo una base comunitaria cohesionada e inclusiva podrá devenir comunidad política. Lo será, será verdadera comunidad política, precisamente, en la medida en que sea inclusiva y todos sus miembros tengan, además de la posibilidad del alcanzar la virtud cristiana, la posibilidad de acceder a la virtud cívica a través de la participación. Esta comunidad cristiana será la agente de una teleología de la salvación que se complementa con una teleología cívica.

\footnotetext{
${ }^{457}$ Sigo aquí a Villacañas (2012).

${ }^{458}$ Villacañas (2012).
} 
Conviene apuntar que, en la concepción de pueblo cristiano, Cartagena no utiliza esta noción de pueblo en un sentido identitario esencialista, como muchas veces los discursos oficiales totalitarios lo han empleado con la violencia que esto puede suponer. El burgalés la usa más en un sentido relacional, esto es, de comunidad esencialmente y místicamente unida, igualada, que coopera y que comparte una idea de salvación.

No es ajena esta visión de comunidad a la idea de comunidad republicana propia del republicanismo renacentista, como explica Marcelo Gisondi ${ }^{459}$ :

El vivir libre republicano siempre tiene un momento de fundación (...) Los fundadores no son sólo los que crean una comunidad política, sino también los que son capaces de restablecer el vivir libre dentro de una república y son capaces de mantener cohesión en la comunidad (como los fundadores religiosos). Maquiavelo llama a esta figura "redentor". Para Maquiavelo la creación del pueblo y la fundación del Estado son un elemento clave, que precede conceptualmente al vivir libre republicano. Este momento de fundación es el punto de apoyo de la interpretación republicana de Viroli, es un momento de "investidura radical", esto es, la "encarnación mítica" en una demanda política.

Realiza Cartagena una lectura de la temporalidad de la Historia permeada además profetismo hebreo, es más, permeada de pensamiento sefardita: recordemos cómo Maimónides hacía hincapié en la unión del pueblo —aunque en su caso es un pueblo al que le une precisamente su diáspora, un pueblo unido en la promesa, donde la suplantación de lo profético pondría en riego a la comunidad— ${ }^{460}$. Este rasgo éste obviamente diferenciador entre Maimónides y Cartagena, es decir, Cartagena se desmarca de esta idea de unión en la diáspora (la cual, por otro lado, nutre al marranismo, grupo ideológico en parte antagónico de los conversos, aunque ambos comparten también multitud de explicables similitudes). Pero, a pesar de que no comparta este rasgo concreto de la diáspora, sí reproduce Cartagena la importancia que su matriz cultural hebraica da al pueblo unido. Quizá en este comportamiento ambivalente de tomar la herencia cultural de la que se viene, pero a la vez criticarla o negarla es propio de intelectuales judíos asimilados. De todos modos, en un contexto de necesario pragmatismo generado por la búsqueda de la propia supervivencia, es lógico que la noción de comunidad para

\footnotetext{
${ }^{459}$ Gisondi (2016).

${ }^{460}$ Al igual que luego Lacan definirá al pueblo por su falta, o lo hará Deleuze en su concepto de pensar el porvenir.
} 
los conversos no pueda ser forjada en un futurible o un anhelo, sino todo lo contrario, que estuviera basada en la inclusión práctica, tangible, en la aceptación en la comunidad dominante, en la posibilidad de acceso y participación en ésta.

Rezuma en nuestro autor también la temporalidad mesiánica que aporta Pablo al cristianismo - a su vez, evidentemente, transida de judaísmo - . Es lo que Giorgio Agamben llama el tiempo que resta, en su libro homónimo sobre el paulinismo, en el cual vincula este mesianismo con la creación de pueblo conformado a través de la salvación ${ }^{461}$. Algo muy similar a lo que Cartagena está promoviendo: un pueblo unificado, el cual será recurrentemente inaugurado en la fenomenología fundacional del bautismo. Un pueblo que podrá ser conformado por todos. Un pueblo nuevo que inaugurará una nueva temporalidad, una nueva historicidad en la unidad. Y que inaugurará con ello también una nueva ciudadanía. Además, cada vez que un nuevo miembro acceda al cristianismo a través del bautismo, se reproducirá de nuevo esa inauguración del tiempo nuevo y se consolidará su dimensión comunitaria. Así lo expone nuestro autor $^{462}$ :

El mismo también es nuestro Dios, y nosotros somos su pueblo, y todos los hombres hemos sido reducidos a un solo linaje para que no se hable más de dos linajes, sino de uno solo y de un solo pueblo (...) con la llegada del Salvador las dos ramas y los dos leños han sido unidos en el cetro de un nuevo imperio, porque en el bautismo de Cristo las cosas por largo tiempo separadas se juntan en un solo hombre nuevo y en un solo pueblo.

Y el que este pueblo en su materialización política terrenal pueda estar guiado por un líder no es incompatible con esta narrativa, un líder que además estará unido amorosamente al resto del pueblo nuevo (recordemos lo dicho sobre el organicismo en los capítulos anteriores de este trabajo). Es más, es algo coherente y esperable, y la labor de dicho líder será apoyada y promovida por Dios. Y es precisamente ahí donde los conversos refunden su profetismo de matriz hebrea con su apoyo al monarca cristiano, éste, vicario de Cristo en la defensa de la fe, ha de guiar este proceso de refundación permanente del pueblo y condenar la peor de las herejías, que es el querer segregar a este nuevo pueblo, romper su mística cohesión — que también ha de

\footnotetext{
${ }^{461}$ Así titula Agamben su libro sobre la impronta de Pablo: El tiempo que resta Comentario a la Carta a los Romanos. Madrid. Trotta, 2006.

${ }^{462}$ Cartagena (1993): 198.
} 
ser política - es decir, querer expulsar a los conversos de ese nuevo pueblo e impedirles su participación civil (como veremos más adelante), pues este pueblo nuevo ha de recibir en su seno a todos quienes lo deseen.

Efectivamente, para Cartagena la herejía más flagrante es querer fragmentar a este pueblo esencialmente unido por la acción de la revelación y la redención, por la gracia que todos por igual reciben. No es casual que el texto que nos ocupe se titule 'defensa de la unidad de los cristianos'. Fernando Miguel Pérez Herranz señala la importancia de considerar esta dimensión ontológica al abordar el Defensorium esto es, «leerlo teniendo en cuenta la cuestión de la unidad y la pluralidad de las entidades del mundo» ${ }^{463}$. Según Cartagena esta unidad ontológica del género humano gracias a la revelación, está sustentada en Dios, y además, en dicha unidad el género humano se iguala. Para nuestro obispo, esta unión de la humanidad bajo la fe en Cristo, es decir, la unitas cristiana, y el hecho de que también los judíos han de formar parte de ella porque, asimismo, a ellos les fue dada la revelación puede demostrarse (algo que Cartagena realizará a través del Defensorium). Mediante sus teoremas usará numerosos ejemplos bíblicos, históricos y teológicos, así como referencia a personajes ilustres (sobre todo hebreos veterotestamentarios) para probar realidades como que «(...) por medio del redentor del mundo, Jesucristo nuestro Señor, el pueblo israelita fue completamente redimido», que «(...) todo el mundo ha recibido la gracia de la salvación por medio del mismo Salvador y del mismo modo», o que «(...) al entrar en la fe católica por la puerta del sagrado bautismo no persisten como dos pueblos [el judío y el cristiano] o como dos linajes diferentes, sino que de los procedentes de una y otra parte se crea un pueblo nuevo» ${ }^{464}$. El Defensorium, además de probar todo lo anteriormente dicho en este apartado, propone un modelo práctico para llevarlo a cabo, un diseño de proyecto de convivencia y creación de base comunitaria.

Nuestro obispo toma además en el Defensorium recurrentemente la imagen de la luz, esto es, de la fe como luz que orienta e ilumina a los cristianos, y que los iguala a todos bajo un mismo resplandor y guía. Todos son susceptibles de su luz. Toma esta idea a raíz de un pasaje de Juan, idea, además, muy propia del iluminismo castellano pre-erasmista (que no debía serle para

\footnotetext{
463 Pérez Herranz (2016): 286.

${ }^{464}$ Cartagena (1993): 145, 177 y 189.
} 
nada lejano, como explicamos en el capítulo 2) y la emplea para consolidar teológicamente una idea principal del Defensorium, que era promover la unidad, así lo explica Stefania Pastore ${ }^{465}$ :

En torno al pasaje de Juan I, 9 «Erat lux vera, quae illuminat omnem hominem venientem in hunc mundum», uno de los versículos más frecuentemente citados y recordados en la Castilla de los alumbrados, se ordenaba el mundo religioso de Cartagena y tomaba forma la manifestación más importante del Defensorium unitatis fidei. La metáfora de la nueva fe como iluminación guiaba la reconstrucción de Cartagena, y convertiría esta metáfora en el punto clave de toda manifestación sobre la unidad inseparable del pueblo cristiano.

Y no sólo esto, Cartagena enlaza en el Defensorium este motivo de la luz como guía espiritual con la idea de que ésta es también guía epistémica, herramienta de conocimiento. Por ello, al ser iluminado por la fe, también al cristiano le será accesible el conocimiento. La luz solar, que todos ven y que permite verlo todo, es equiparable a la iluminación espiritual que irradia el Evangelio. A este respecto retoma nuestro autor la teoría de la iluminación sobre el conocimiento intensivo y extensivo de Pseudo-Dionisio, Lucas, Pablo y Tomás de Aquino ${ }^{466}$. Expone Cartagena $^{467}$ :

Encontramos las luces que iluminan el alma semejantes a estas tres luces que suelen iluminar los ojos del cuerpo, de las cuales una es extensa, pero no intensa; otra, por el contrario, ilumina intensa, pero no extensamente; la tercera, en cambio, sin comparación posible, sobrepasa a las demás tanto en extensión como en intensidad. La primera es la luz de la luna, que, aunque se extiende por toda la tierra, sin embargo, proporciona poca luz iluminadora (...) A esta, pues luz lunar, no por cierto de manera inapropiada comparamos con la luz de la razón natural que es tan extensa que se acomoda a todo hombre, al no ser el hombre otra cosa más que un animal racional; su claridad, sin embargo aunque contribuya a conocer a Dios y también a conocer algunas propiedades de la virtud (...) es también defectible y oscura para la contemplación intelectual de las cosas elevadas. Eso se debe a que nuestro conocimiento natural tiene su origen en los sentidos (...) Nuestro entendimiento, pues, no puede llegar de los sentidos a la visión de la esencia divina.

\footnotetext{
${ }^{465}$ Pastore (2004): 5, 6. La traducción es nuestra, el texto original es: “Attorno al passodi Giovanni I, 9 «Erat lux vera, quae illuminat omnem hominem venientem in hunc mundum», uno dei versetti più frequentemente citati e ricordati nella Castiglia degli alumbrados, si ordinava dunque il mondo religioso di Cartagena e prendeva forma la dimostrazione piu importante del Defensorium unitatis fidei. La metafora della nuova fede come illuminazione guidava la ricostruzione di Cartagena, che ne faceva il punto chiave di ogni dimostrazione sull'unita inscindibile del popolo cristiano".

${ }^{466}$ Cartagena (1993): 125 a 137.

${ }^{467}$ Cartagena (1993): 127.
} 
Y prosigue explicando un poco más adelante ${ }^{468}$ :

Intensa, más no extensa, diría yo que es aquella luz que está compuesta de fuego material, cuya claridad se extiende poco, como sucede bajo el techo de una casa o de una iglesia o de cosa semejante, pero que dentro de esos límites nos alumbra vivamente (...) Y esta iluminación corporal, por cierto, la podremos comparar con la ley escrita, que también fuera trasmitida por medio de la luz, pero poco extensamente, porque, como acabamos de decir con anterioridad, se extendía tan sólo al pueblo de Israel; sin embargo, a las almas de los vinculados a la ley las iluminaba más intensa y profundamente que la luz de la razón natural. (...) La tercera intensísima y extensísima luz (...) visible a todos los hombres con claras señales: es la brillantísima luz del sol (...) ¿quién hay que no diga que parezca corresponder aquella iluminación espiritual que irradia la luz evangélica que no rechaza a ojo alguno que esté dispuesto a usar de ella (...)

Continúa Cartagena ${ }^{469}$ :

El Espíritu Santo (...) iluminó y calentó los espíritus de otros hombres, tanto de los judíos como de los gentiles que aún no habían recibido la fe (...) y que obscurecidos por la ausencia de este Sol no encontraban la patria del alma, pues dice Isaías [Isaías 9, 2]: el pueblo que andaba en tinieblas vio una gran luz. Sobre los que habitaban en la tierra de las sombras de la muerte resplandeció una brillante luz (...) hablaba [Isaías] más bien de este Sol eterno que lo desborda todo intensa y extensamente.

Cartagena usa además esta imagen de la luz también como argumento para explicar que todos, independientemente del origen somos susceptibles de ser iluminados por ella — por esta luz-gracia de la revelación-, ésta llega a todos sin excepción, precisamente por ser extensiva. Y justo por esto no excluye a nadie, incluso esta luz es un vehículo de unión, su resplandor pulveriza toda diferencia. En sus palabras: «En Cristo, pues, esplendor eterno y segundo Adán sin mancha, se disipó toda la ceguera de los ojos del corazón de una y otra gente, y cesó toda diferencia de pueblos y de linajes, porque todos volvieron en este segundo Adán puro a la unicísima unidad» ${ }^{470}$.

Acerca de esta reflexión epistemológica con la imagen de la luz como hilo conductor que hace Cartagena, es sugerente también la lectura que hace Luis Fernández Gallardo, que la

\footnotetext{
${ }^{468}$ Cartagena (1993): 130.

${ }^{469}$ Cartagena (1993): 131, 132.

${ }^{470}$ Cartagena (1993): 135.
} 
vincula con la opinión del conocimiento de la historia por parte del autor. Explica Fernández Gallardo que para Cartagena éste sería como la luz lunar: racional pero incompleto. Escribe así el estudioso $^{471}$ :

Así, el obispo de Burgos viene a reconocer que el deseo de conocer el pasado se adecúa a la razón, lo que, interpretado en términos epistémicos, perfila una coherente concepción del saber histórico. El obispo de Burgos reconoce que la razón humana está sujeta a error $\mathrm{y}$, sobre todo, que no proporciona sino un conocimiento parcial de la realidad. Lo imperfecto de tal conocimiento deriva del fundamento, de la fuente de que se nutre, los datos que proporcionan los sentidos. La razón se limita, pues, al ámbito de la realidad sensible. Por ello, aunque es insuficiente para alcanzar la esencia divina, contiene, empero, luz suficiente para sugerir principios que guíen el comportamiento humano. Y en este punto es donde la reflexión epistemológica viene a ilustrar la naturaleza del saber histórico.

Cartagena es muy crítico con los judíos que son reticentes a la conversión, y de los que como converso quiere claramente desmarcarse, es decir, es crítico con los renuentes a bautizarse y ser nuevos hombres - $\mathrm{y}$ por ende, nuevos ciudadanos de la universal república cristianapues entiende que éste es su destino marcado, también por el propio judaísmo, por la propia ley veterotestamentaira (de acuerdo a esa relación causal entre judaísmo y cristianismo de la que hablábamos arriba). Así lo expresan sus palabras: «Los judíos aceptan, pues, la cara externa de la ley, esto es la superficie de la letra que mata, no la interioridad del espíritu que vivifica, porque siguen solamente el aspecto externo de las palabras, no penetran en la auténtica fuerza vitalizadora y en la plenitud de la ley porque tercamente no siguen a Jesucristo, quien no vino a romper la ley, sino a cumplirla» ${ }^{472}$.

Pese a dicha crítica, Cartagena es respetuoso con la tradición cultural de la que viene. De todos modos, a este respecto de la conversión de los judíos es justo reconocer también la ambivalencia de nuestro autor, quizá por su propia naturaleza de asimilado (si se nos permite esta referencia anacrónica tomada de los judíos asimilados en el siglo XX), pues hay momentos también del Defensorium en que los califica muy negativamente al judaísmo, por ejemplo, de «enfermedad», y momentos en los que parece implacable con los judíos que no se convierten, y a

\footnotetext{
${ }^{471}$ Fernández Gallardo (2002): 297.

${ }^{472}$ Cartagena (1993): 280.
} 
quienes incluso cree que hay que perseguir y castigar ${ }^{473}$. Sin embargo, por el contrario, hay momentos - la mayoría - en los que rechaza la conversión forzosa y apoya una respuesta punitiva sólo contra los que judaízan — es decir, quienes una vez convertidos, o sea, que ya son cristianos a todos los efectos para Cartagena, siguen practicando ocultamente el judaísmo - - De éstos últimos escribe: «Por consiguiente, todo judaizante o paganizante, o que de cualquier manera se aparte de la fe católica recibida, ha de ser reprimido por el juez eclesiástico, y si es posible, al arrepentido hay que volverlo al recto camino de la fe, al pertinaz, en cambio, o al declarado por el juez eclesiástico como reincidente de herejía con falso juramente, el poder secular tiene que castigarlo de acuerdo con la ley» ${ }^{474}$.

Es algo más tolerante con los judíos que mantienen su credo. Opina de ellos que están «ciegos», que son «malvados», «tercos», «impíos», pero que no son apóstatas o herejes, pues no engañan, cosa que hacen los que judaízan, «los sacrílegos que una vez bautizados recaen» ${ }^{475}$. En cualquier caso, expresa su disgusto con aquellos judíos que no abrazan la conversión, e, incluso, en un momento dado lanza la idea de que se condenarán - idea que nos retrotrae al concepto de temor de Dios - y de que no alcanzarán la Jerusalén celestial, esto es, la salvación. Eso sí, aun en este discurso en el que sobrevuela la idea de castigo, nuestro burgalés hace una apología de la unidad y la inclusión. Afirma ${ }^{476}$ :

[El Espíritu Santo] iluminó a todo el mundo al invitar a todos a contemplar el resplandor de su luz, absolutamente a todos, de cualquier nación o procedencia que fuesen. He aquí lo que nuestro mismo Redentor dice: id por todo el mundo y predicad el evangelio a toda criatura. El que creyere y fuere bautizado se salvará, mas el que no creyere se condenará (...) Y no fue Jerusalén la que se dirigió a los gentiles, sino que es el pueblo gentil el que se vuelve a Jerusalén, para de uno y otro pueblo establecer la única y verdadera Jerusalén, que en esta vida es la Iglesia militante por medio de la cual se sube ala Jerusalén celestial y en la que todos, de cualquier parte que vinieran, caminarían en la luz sin enemistad.

Retomando esta idea de la ceguera vinculada al judaísmo - una ceguera que se entendía como electa, pues la padecía quien había desoído voluntariamente la buena nueva evangélica y se había ofuscado en el judaísmo - es muy sugerente señalar la representación visual alegórica

\footnotetext{
${ }^{473}$ Cartagena (1993): 240 y ss. También se desarrolla esta crítica en Cartagena (1993): 279 y 280.

${ }^{474}$ Cartagena (1993): 380.

${ }^{475}$ Cartagena (1993): 333.

${ }^{476}$ Cartagena (1993): 132, 133.
} 
que en la Edad Media europea se hizo recurrentemente de la «Ecclesia» en comparación con la «Synagoga», ambas representaciones alegóricas se contraponían. A continuación (en la página siguiente) mostramos dos ejemplos. El primero está en la Catedral de Notre Dame en París, y el segundo en la Catedral de Estrasburgo, ambos datan del siglo XIII y están atribuidos a Erwin von Steinbach (aunque se cree que, en verdad, fue su hija Sabina quien realizó estas esculturas). Tomamos esta información a raíz de una conferencia de Nina Rowe titulada "Keeping the Jews in Their Place: Images of Synagoga in the High Middle Ages", presentada en el Visual Arts Center de la Fordham University el 28 de octubre de 2009. Dicha autora sostiene que el par de figuras fue emplazado en diversas iglesias importantes de distinas ciudades europeas a lo largo del medievo, y que pretendía proyectar la imagen de un judaísmo debilitado. 


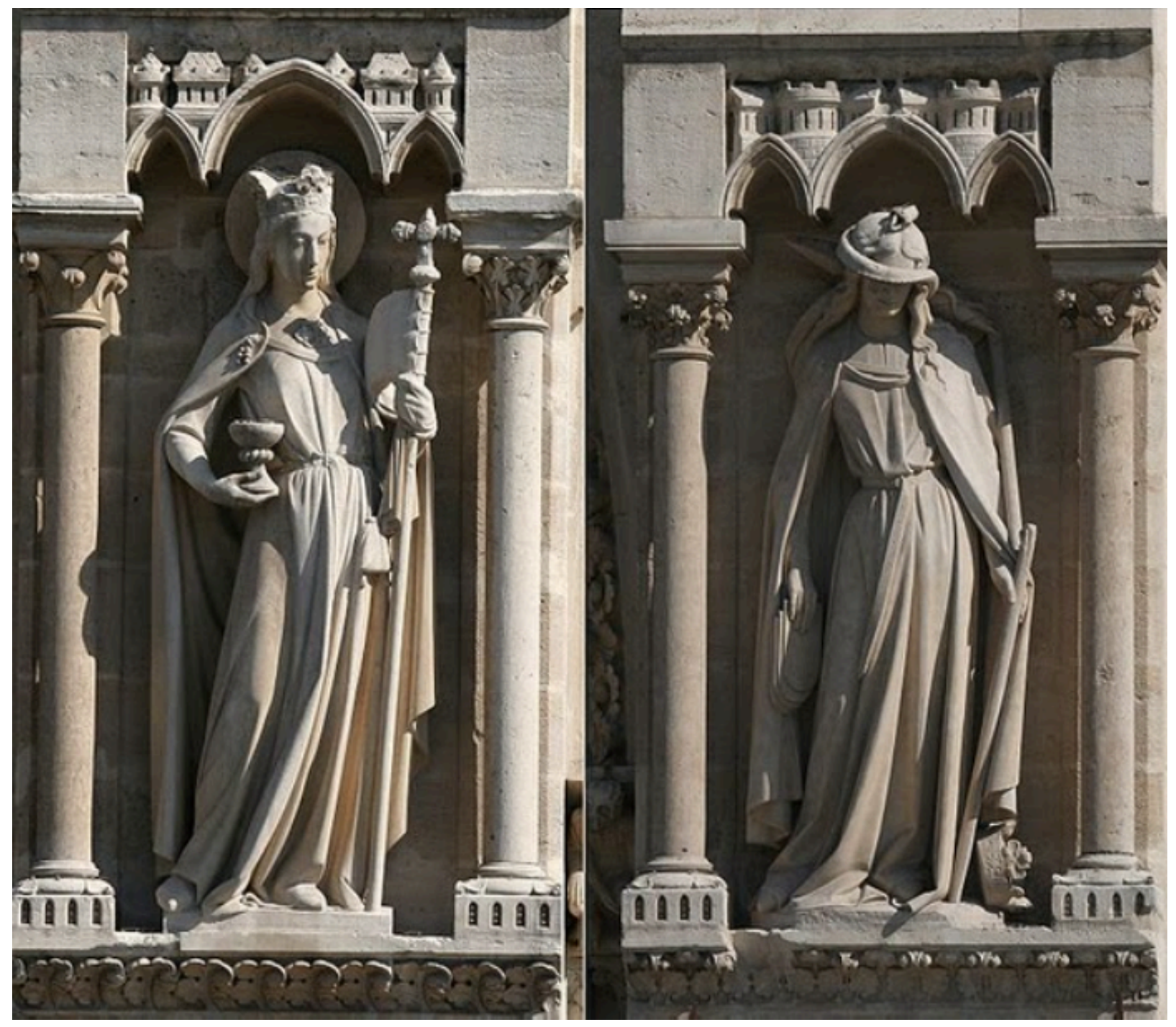

La Iglesia (figura de la izquierda) se muestra en plena magnificencia: triunfante, coronada, erguida, y, sin embargo, la Sinagoga (a la derecha) aparece con la mirada cegada por un velo (que, además, parece ser una serpiente), con la corona caída, con las tablas de la ley invertidas y con el cetro quebrado. 


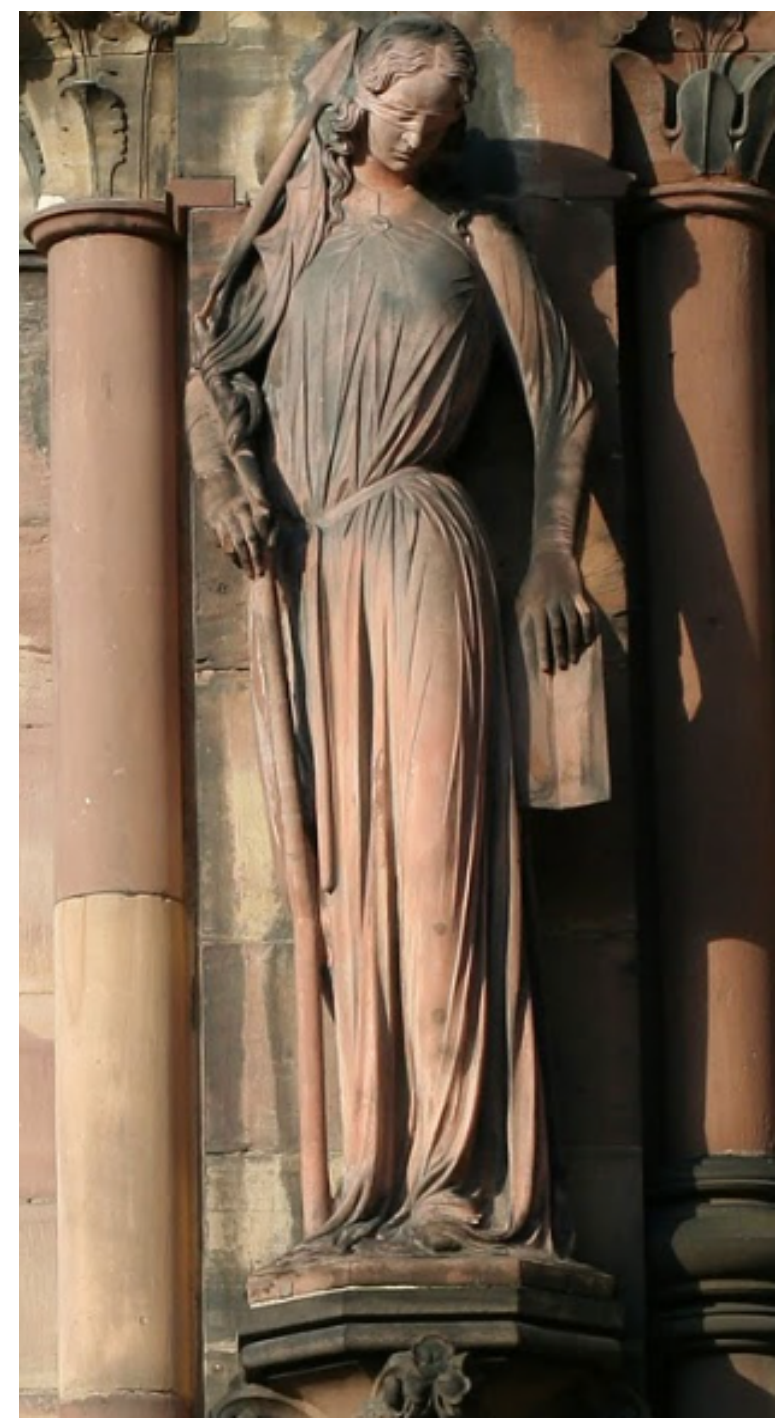

También aquí la Sinagoga está cegada y su lanza partida, además de tener la cabeza agachada.

En cualquier caso, y volviendo a la Cartagena, a pesar de su crítica a los judíos que no han aceptado la conversión, no pareciera renegar del Antiguo Testamento ni el patrimonio cultural judío, y tampoco de su origen hebraico. Al menos así da que pensar lo que dejara escrito en boca de Cartagena Juan de Lucena en su De vita beata ${ }^{477}$ :

\footnotetext{
${ }^{477}$ Tomo la cita de Pastore (2004): 42.
} 
No piense correrme por llamar los ebreos mis padres. Sonlo, por çierto, y quiérolo; ca si antiguedad es nobleza ¿quién tan lexos? Si virtud ¿quién tan cerca? O sy al modo despaña la riqueza es fidalguía, ¿quién tan rico en su tiempo? Fué Dios su amigo, su señor, su legislator, su cónsul, su capitán, su padre, su fijo, y al fin su redemptor. ¡O immortal Dios! Todos los oprobios son ya trasmutados en gloria, y la gloria contornada en denuesto.

También se trasluce de la obra de Cartagena en general una visión positiva de la diversidad existente en Castilla, en su De preeminentia habla de la: « (...) fermosa diferencia de tierras e de gentes; e esto es lo que se sigue en el dicho de Aristótiles, que dice: diversas entre sí en muchedunbre e grandesa e fermosura (...) de la fermosa diferencia de las gentes, el regno de Castilla sobrepuja (...) a so el señorío de mi señor el Rey ay diversas nasciones e diversos lenguajes ${ }^{478}$.

A lo largo del Defensorium, pero sobre todo en la primera parte, se encargará Cartagena, además de demostrar esta filiación natural entre judaísmo y cristianismo, siendo éste una culminación natural de aquél, de recordar la nobleza (en el sentido de dignidad y virtuosismo) del pueblo judío y de darle su justo lugar y mérito en la narrativa de la salvación. Empleando el recurso de los exempla ilustres, argumenta nuestro obispo que prueba la nobleza inherente al pueblo judío es la existencia de múltiples reyes y sacerdotes dignos de admiración, muchos de los cuales va mencionando. A modo de ejemplo tomamos esta expresiva y retórica loa a personajes judíos ${ }^{479}$ :

¿Quién más prudente que Salomón? ¿Quién más justo que Samuel? ¿Quién más fuerte, no diré que Sansón para que no parezca que tomamos la fortaleza en el sentido de fuerza física, sino que David y que algunos de sus soldados que en el sagrado canon son alabados como fortísimos? ¿En la actividad militar y en la grandeza guerrera no tuvieron Macabeo y sus hermanos no solamente fortaleza militar y política, sino también la más auténtica fortaleza por efecto de la virtud, o, por mejor decir, por efecto del creador de la virtud misma, el Dios por el que ellos virilmente peleaban? ¿Quién, pues, no apreciará que la virtud ha brillado en José, en Susana, y en otros muchísimos que prefiriendo la virtud del alma a la vida del cuerpo renunciaron con gran peligro suyo a los contactos prohibidos? Y si queremos conceder nobleza a la virtud moral, ¿no fueron acaso aquéllos, nobles?

\footnotetext{
${ }^{478}$ Tomamos esta cita de Penna (1959): 218.

${ }^{479}$ Cartagena (1993): 222.
} 
El uso del término «noble», además de a una acepción jurídica bartoliana que luego mencionaremos, se vincula en época de Cartagena a alguien digno de conocer gracias a sus virtudes morales, así lo explica el Diccionario crítico etimológico castellano e hispánico de Joan Corominas, que indica que a este término, que deriva del latino noscibilis, se le da tal uso culto desde el siglo XII; es probable que Cartagena lo empleara también con esta connotación ${ }^{480}$.

\subsection{Uso de la metáfora organicista: iguala y cohesiona.}

Otro eje que da forma al Defensorium y a su idea de comunidad, y por tanto útil para nuestro análisis, es cómo emplea nuestro obispo la metáfora organicista (a la cual ya hemos hecho mención en varios momentos de este trabajo). La metáfora organicista en su desarrollo paulino de Iglesia como cuerpo místico de Cristo le sirve a Cartagena para argumentar en pro de la igualdad y cohesión de los cristianos, y le sirve también — rasgo éste original de nuestro autorpara fortalecer su idea de inclusión. A colación del uso de esta metáfora paulina en el mundo converso, como ya apuntamos en el Capítulo 2, afirma Albert Sicroff: «En España se le dio al paulinismo precisamente el sentido universalista que había defendido el apóstol» ${ }^{481}$. La metáfora organicista será otro argumento para demostrar que una vez que se accede a la cristiandad, todas las diferencias quedan anuladas. Asevera Cartagena: «De estos dos grupos que mencionamos es bien sabido que cuando acceden a la fe católica se forma una sola Iglesia, un solo pueblo, un solo cuerpo, cuya cabeza es Cristo» ${ }^{482}$. Lo expone, asimismo Cartagena, en frases tan expresivas como ésta ${ }^{483}$ :

(...) y a todos los católicos les concederá [la gracia, el amor, la revelación] el que permitió que su cabeza fuese atravesado por espinas, su costado por una lanza, sus pies por clavos, y todo su cuerpo desgarrado por los azotes, y ofendido con innumerables oprobios, para que todos los creyentes, de donde quiera que procedieran, constituyan un solo e indivisible cuerpo bajo un amor verdadero, no fingido, y exento de toda ofensa de hermanos ente sí.

\footnotetext{
${ }^{480}$ Corominas (1984): 176.

481 Sicroff (1982): 656.

482 Cartagena (1993): 189.

${ }^{483}$ Cartagena (1993): 400.
} 
Dicha identificación, tan recurrente en filosofía política $y$ tan utilizada contemporáneamente a Cartagena por las teorías del principado — que permean a nuestro autory por el pre-erasmismo para justificar planteamientos de igualdad y de cohesión del orbe cristiano, la toma también el burgalés en la línea paulina. Esta relación mística hace inviolable unidad de la república cristiana — pues es inherentemente un cuerpo indivisible_- Esto es bien parecido a lo que explicábamos sobre la asimilación sinecdótica 'príncipe-pueblo' intrínseca al organicismo político en relación con la idea de monarquía. La diferencia es que en éste no hay una argumentación trascendental ni mística como sí sucede al hablar de cuerpo místico de Cristo.

De este modo la idea de cuerpo de Cristo es en el Defensorium empleada para argumentar esa necesidad de unidad, pero va más allá, pues, como apunta Francisco Castilla, constituye un vínculo de sociabilidad, algo también muy republicano ${ }^{484}$ :

La metáfora organicista desempeña así una triple función: igualadora, unificadora y gratificadora. En virtud de la primera, se reconoce exclusivamente a los individuos, que se integran todos ellos en igualdad de condiciones como miembros del corpus mysticum; por la segunda, los distintos miembros llamados a engrosar la grey cristiana, sea cual sea su origen, se unen en un solo cuerpo, el de Cristo, que es la Iglesia; pero, a la vez y en tercer lugar, ese cuerpo ejerce una función santificadora: al unirse al cuerpo de Cristo todos los fieles reciben su gracia, lo que los libera del pecado.

Asimismo, la identificación organicista se torna para Cartagena un pilar para explicar la necesidad de creación de comunidad (en una impecable hibridación y traductibilidad del concepto de comunidad religiosa con el de comunidad cívico-política). Aseverará incluso el Defensorium: «Y así resulta que el cuerpo místico compuesto de esta forma y materia se llama ciudad ${ }^{485}$. Al más puro estilo de Cartagena, estamos ante un trasvase de valores religiosos a la nueva realidad política. Incluso, nuestro obispo avanza todavía otro paso hacia una solidaridad cívica, lo observamos en sentencias como ésta: "Así nosotros siendo muchos somos un solo cuerpo en Cristo, pero cada miembro está al servicio de los otros miembros» ${ }^{486}$. Respecto al uso de la metáfora organicista apuntar también de nuevo, como ya hicimos en el capítulo segundo, el

\footnotetext{
${ }^{484}$ Castilla (2011): 96. Véase también al respecto Castilla (2010).

485 Cartagena (1993): 392.

${ }^{486}$ Cartagena (1993): 210.
} 
sugerente análisis de Nieto Soria, para quien en su vertiente transpersonalizadora tiene una clara ligazón con la idea republicana de comunidad política, de cuerpo político unido ${ }^{487}$.

Indica también lúcidamente el estudioso Francisco Castilla sobre la repercusión política de esta identificación organicista en Cartagena ${ }^{488}$ :

Pero la analogía en Alonso de Cartagena (y en la mayor parte de los autores que tienden a utilizarla antes del siglo XVII) adquiere su pleno sentido no tanto por la subordinación de las partes a la cabeza, sino por su contribución a la preservación de la unidad del cuerpo $\mathrm{y}$, sobre todo, por la creencia en un orden armónico, sin duda excesivamente idealizado, que excluye tanto la dominación desmesurada como la rebelión, y que supone un servicio sin límites a la república.

Es también digno de mención, en esta voluntad de entender el empleo de la metáfora organicista como una forma de promover la inclusión, el Lumen ad revelationem Gentium, escrito en 1465 por Fray Alonso de Oropesa, y que Sicroff ve como un texto heredero del Defensorium de Cartagena: el teórico francés opina que incluso lo supera en su alegato por la unidad de todos los cristianos, aunque con una componente más teológica y menos jurídica y política en su argumentación, pues para Oropesa lo que verdaderamente cohesiona a los cristianos es su comunión ante el sacrificio eucarístico ${ }^{489}$.

Para Cartagena la mayor herejía, la mayor aberración para la fe, es quebrar la unidad de los fieles. Ésta es la mayor turbatio para la paz, por ello él es tremendamente duro e insta a que sean castigados quienes promueven escindir a los fieles según su «secundum carnis nathalia», esto es, según si provienen del pueblo de Israel o de la estirpe gentil. Esta segregación rompe la fraternidad universal de los cristianos, y el querer separar la unidad del orbe cristiano es para él un acto de mal extremo. De esta terrible herejía acusa con vehemencia en el Defensorium a los cabecillas de la revuelta toledana y al bachiller Marcos García de la Mora. Por ello el uso de esta metáfora organicista en el Defensorium da una vuelta de tuerca más a como se había usado antes, ya sea en lo político, ya sea incluso en lo religioso siguiendo la idea paulina de cuerpo místico de Cristo: en el modo en el que Cartagena usa la noción de unidad hay un pliegue de inclusión, de

\footnotetext{
${ }^{487}$ Nieto Soria (1998).

${ }^{488}$ Castilla (2011): 90.

${ }^{489}$ Sicroff (1982).
} 
exhortación a la inclusión, de aceptación del 'otro', y de vocación de comunidad extendida y receptiva, que no había habido antes. Todos pueden formar ese cuerpo místico, todos son aptos, todos son válidos independientemente de su origen, y, es más, precisamente, ese pasar a formar parte de la Iglesia, ergo del cuerpo místico, elimina automáticamente toda diferencia. Cartagena utiliza esta metáfora como argumento para su causa. A largo de todo el Defensorium se evoca y reitera esta idea de necesaria cohesión e inclusión, de hecho, parece que para Cartagena el romper esa vocación inclusiva pervierte la esencia de la misma de la cristiandad, mancilla el propio sacrificio de Cristo (un acto, como lo son su amor o perdón universales, de una inclusividad radical). Se pregunta emotiva y retóricamente ${ }^{490}$ :

Contra mí se levantó la herejía cainita y alzó su aplastada cabeza la extinguida víbora para trastornar no parte, como antes solía, sino todo el misterio de Cristo, porque dice que hay algunas cosas que Cristo no podría limpiar con su sangre y que se imprimen en los cuerpos y las almas tan profundas heridas de sus precedentes iniquidades que no puedan ser eliminadas por los remedios de cristo. ¿Qué otra cosa trata de decir, sino que Cristo ha muerto en vano? Pues en vano ha muerto si hay alguno al que no pueda darle la vida.

\subsection{Instrumentalización política de elementos teológicos para conformar una ratio de la inclusión y del acceso a la ciudadanía. El bautismo como posibilitador de participación cívica.}

Desde el ángulo de la filosofía política éste es un punto que hemos venido anunciando desde el principio de este trabajo por ser para nosotros de gran interés, en Alonso de Cartagena en general, y en su Defensorium en particular: nos referimos a la instrumentalización política de nociones teológicas. Característica ésta de la articulación entre elementos de la teología cristiana y elementos propios del pensamiento republicano que consideramos paradigmática del pensamiento político converso y de Cartagena.

Cartagena lleva a un clímax cívico - y adapta al pensamiento político de su momento y a la situación concreta de exclusión que están sufriendo los conversos - toda una tradición teológica en la que encontramos a Pablo, a Santiago, a Agustín de Hipona, a Tomás de Aquino, y al aristotelismo cristiano. Nuestro autor actualiza esta tradición al hibridarla con el

\footnotetext{
${ }^{490}$ Cartagena (1993): 247.
} 
republicanismo renacentista que es antesala de la modernidad política. Del Defensorium puede extraerse una fértil traductibilidad entre elementos religiosos y elementos republicanos. Y esta traductibilidad se realiza en dos direcciones que se retroalimentan y que son haz y envés de lo mismo: por un lado en el Defensorium hay un proyecto político cuya racionalidad promueve la inclusión y la universalidad en el acceso a la ciudadanía y a la participación, y para implementar esta ratio política se sirve Cartagena de la teología (de elementos como el bautismo o la gracia). Por otro lado, para lograr que la cristiandad sea una verdadera comunidad cohesionada, Cartagena incorpora a la noción de communitas cristiana principios republicanos: la comunidad cristiana, la cual está en peligro de ser quebrada por quienes no aceptan a los cristianos nuevos en ella, ha de estar cohesionada también por un vínculo cívico y fraterno, ha de ser también ciudad en la que todos sin distinción - sin exclusiones - puedan participar con el mismo objetivo de un bien común. Como él mismo indica, para que exista ciudad lo que hay que tener en cuenta es la posibilidad de participación de sus habitantes.

Vinculada a esta idea de comunidad, es muy interesante la apreciación hecha por el Fernando Miguel Pérez Herranz acerca del aristotelismo cristiano de Cartagena $-\mathrm{y}$ en general del ámbito converso-, por ello nos permitimos una cita tan extensa. Expone dicho estudioso ${ }^{491}$ :

El fundamento de la constitución de la virtud pasa por modalidades de comunicación para resolución del completud humana frente a la ontología del cogito (...) El amor solitario y exclusivo a Dios, de raigambre platónico-agustiniano, da paso a un amor al otro en cuanto individuo, que alcanzó su límite en la amistas aristotélica. Dios empieza a ser mediatizado por el amor a los hombres, clave para alcanzar la paz, vínculo entre la ética la política (...) El espacio político, público, que ha de tener presente las condiciones de la naturaleza de los hombres por medio de la comunicación y participación de todos, permite la consecución de la paz. Tal era el proyecto de los tornadizos [los conversos], que será atacado por los lindos [los cristianos viejos.]

Acerca de la importancia de la participación cívica para Cartagena, de la que se puede inferir su familiaridad y acercamiento a las ideas republicanas, escribe en el Defensorium estas bellas y relevantes palabras ${ }^{492}$ :

\footnotetext{
${ }^{491}$ Pérez Herranz (2016): 302, 303.

${ }^{492}$ Cartagena (1993): 386 y 389.
} 
La disposición, participación y dependencia que se da en las ciudades para gobernar, y a la que llamamos política o "politheuman", es la forma esencial de la ciudad en cuanto a que ciudad, porque aunque las murallas parezcan constituir la ciudad y fijarla con ciertos límites, la ciudad, sin embargo, no está representada por las murallas, sino por la clase de gobierno. Por eso dice Tomás que la participación del lugar no es la ciudad, sino que la ciudad es la participación del bien vivir (...) Por consiguiente, para la existencia de la ciudad no hay que tener en cuenta la unidad de las murallas, sino la calidad de la participación de que disfrutan los habitantes (...) Por lo expuesto queda claro que la ciudad se llama ciudad no por la unidad de sus murallas, sino por la unidad de su política.

En esta línea de reivindicación del papel central que la ciudad tiene en el pensamiento de nuestro converso, y de su articulación con el republicanismo propio del pensamiento político converso castellano del siglo XV, se orienta el trabajo de Cárdenas y Torregroza, que afirman lo siguiente ${ }^{493}$ :

La filosofía política de Cartagena nos permite comprender por qué desde el siglo XV la filosofía política hispánica recurrió a fundamentos racionalistas clásicos. Cartagena debe apelar al concepto de Ciudad (polis) de la filosofía política clásica para poder defender la unidad cristiana entre cristianos viejos y nuevos, ya que sin el recurso al espacio común de la concepción racionalista de la política no es posible compensar el efecto disociador de las diferencias étnico-religiosas.

Sin duda, como expresan las últimas hojas del Defensorium, Cartagena, deja claro la necesidad de una poliçia, es decir, de una política que regule la sociedad; y deja claro también que las ciudades, y la participación en ellas, son la vía para el recto vivir, para el logro del bien común y para la consecución del Bien último. Afirma en este sentido ${ }^{494}$ :

Y como esto es evidente, también resultará evidente al que lo piense, que no se le llamará ciudad a una multitud de hombres, aunque permanezca reunida en un mismo lugar, a no ser que ordenadamente tienda al bien de la felicidad, porque todas las ciudades y toda la participación humana aspira a algún grado de gobierno (...) Es necesario, pues, para esto, es decir, para que se establezca una ciudad, que los hombre se reúnan allí para vivir bien y hacer cosas en común orientadas a la felicidad práctica que pueda tenerse en esta vida, y que en la república cristiana es la felicidad eterna la que se persigue como último fin

No bastará, sin embargo, para nuestro autor con una vida política activa si ésta no tiene como fin, además del bien común y la felicidad práctica, el fin último de la salvación. Con esto

\footnotetext{
${ }^{493}$ Cárdenas y Torregroza (2011): 7.

${ }^{494}$ Cartagena (1993): 385.
} 
lo que está haciendo Cartagena es alinear la virtud cívica (lograda a través de la participación en el vivere civile) con la virtud cristiana. Obviamente ésta es el fin último, pero el ejercicio de la virtud cívica contribuirá a la teleología de la salvación: la vida práctica desarrollada a través de la participación política consolidará la comunidad política, y a la vez acercará a ésta a ser una comunidad de salvación. En la participación en la ciudad se equilibrará la razón natural política propia del hombre con su dimensión como receptor de la revelación. Así lo hace notar: «Al establecer las ciudades, por medio de ellas, como a través de cierto camino, enderezamos nuestros pensamientos hacia la bienaventuranza eterna como al supremo y último fin» ${ }^{495}$. El orbe cristiano es polis también. Coinciden en esta idea con nosotros Cárdenas y Torregroza, los cuales sostienen: «Para Cartagena, la Ciudad como corolario, tendrá como destino la búsqueda de la verdadera luz, convirtiéndose en el camino prudente — esto es, racional- hacia la promesa redentora de Dios» ${ }^{496}$.

Retomemos ahora la primera de las formas en las cuales afirmábamos que se da en Cartagena esta articulación entre teología y pensamiento republicano, esto es, retomemos lo que apuntábamos arriba de que tras el Defensorium hay también un programa político cuya racionalidad promueve la inclusión y la universalidad en el acceso a la ciudadanía y a la participación, y que para implementarlo se sirve Cartagena de la teología. Pues bien, en este sentido nuestro autor emplea conceptos como la gracia o el bautismo políticamente, concibiéndolos como vehículos de acceso a la ciudadanía activa. Este punto nos parece de máximo interés y valía en Alonso de Cartagena, estimamos que es uno de sus principales aportes: el tratar de que la universalidad propia del mensaje evangélico se aplique a la esfera civil. El tratar de que no haya argumento alguno que pueda sustentar la exclusión de nadie de la esfera de lo político, es decir, que nada pueda expulsar a nadie del ejercicio de la república, pues si Dios, máxima autoridad, ha dispuesto - y materializado en Cristo y su nueva historicidad fundadora de un pueblo nuevo - un mensaje de universalidad, igualdad y cohesión, probados a través de la universalidad de nociones como la gracia, la revelación, el amor, el perdón o la redención (sin importar cuestiones de origen, de credo previo o de raza), ninguna ley o gobierno

\footnotetext{
${ }^{495}$ Cartagena (1993): 386.

${ }^{496}$ Cárdenas y Torregroza (2011): 23.
} 
podrá contradecir esto, y nadie, por tanto, podrá quedar excluido de la posibilidad de participación.

Nos interesa incidir en la idea del bautismo entendido como un instrumento de acceso a la ciudadanía, siendo por tanto ésta una ciudadanía no ligada al origen, en el sentido de queda liberada de la noción de origen racial, social o religioso; lo cual nos parece un elemento de anticipada modernidad y valor.

El bautismo se nos presenta también como una suerte de garante de derechos (si se nos concede, para ser más inteligible, el anacronismo de emplear este término actual), como un generador de ciudadanía, como un liberador de servidumbre, como un elemento igualador y como un otorgador de libertad como no dominación (de nuevo aquí otro pilar del pensamiento republicano). Así lo enuncia nuestro autor ${ }^{497}$ :

La rehabilitación de nacimiento, hecha también por la regeneración del sagrado bautismo, les concederá la condición de libres y todas las facultades del derecho natural primigenio (...) Ninguno de nosotros, por la universalidad del pecado que uno mismo o sus antepasados dejaron tras de sí es más despreciable, o más desdeñable, como tampoco por esto es más libre, o es más idóneo, o es más digno de respeto, sino que por la misma recepción de la fe todo individuo es libre y apto.

Quepa aclarar que de esta cita podría inferirse a priori cierta incompatibilidad con la postura iusnaturalista que unas décadas después sostuvo parte de la Segunda Escolástica — sobre todo en su desarrollo americano - respecto a la idea que los infieles, pese a serlo, ostentan derechos naturales subjetivos y que, por tanto, el bautismo no les "otorga" nada en este sentido $^{498}$. Sin embargo, no pensamos que haya tal incompatibilidad, ni que la idea expresada aquí por Cartagena de que el bautismo concede la condición de libertad (usado en esta cita el término «libertad», opinamos, como no-dominación, y no en un sentido de atributo o facultad

\footnotetext{
${ }^{497}$ Cartagena (1993): 292.

${ }^{498}$ Este debate ya se dio a lo largo del siglo XV en el entorno intelectual del pensamiento político converso y de la Universidad de Salamanca debido a la problemática convivencia entre cristianos, judíos y musulmanes y a la noción de guerra justa, y la postura mayoritaria era que los infieles tenían por Derecho Natural ciertos derechos y la capacidad racional de discernir, ya que este Derecho Natural era intrínseco a la propia naturaleza humana, y por tanto inherente a todos los pueblos independientemente de su religión y formas de vida. De todos modos, no será hasta décadas después y en el ámbito americano, con autores como Bartolomé de Las Casas, donde este debate adquiera ya una mayor nivel de sofisticación.
} 
propia del hombre) y de que el bautismo restituye las facultades del Derecho Natural primigenio, sea incompatible con lo anterior. Por eso Cartagena usa «restituir», esto es, «devolver», en el sentido de que el bautismo devuelve la libertad y los derechos propios del Derecho Natural cuando se está en una situación de dominación y arrebato de derechos, esto es, en una situación como la que estaban viviendo los judíos. No pensamos que esta cita de Cartagena implique que los no bautizados no son depositarios de las facultades otorgadas por Derecho Natural a todos los hombres. A lo que creemos se refiere en esta cita es a que se les restituye su ciudadanía, su libertad. Estimamos que lo que quiere expresar Cartagena es que el bautismo "blinda" ciertos derechos como el honor (fundamental para legitimar la participación en la cosmovisión hispana), la plena libertad, o la posibilidad de participar en la vida pública, esto es, quiere mostrar Cartagena la dimensión del bautismo como una suerte de garante de derechos civiles, como una herramienta que protege de la vulnerabilidad de quien es un potencial excluido. Si todas personas son dignas de recibir la gracia, el amor de Dios y la revelación — cuya fenomenología es el bautismo-, el bautismo habrá de garantizar la universalidad de derechos, uno de los cuales es el poder participar en la vida pública y poder así construir república, tanto cristiana y como política (pues recordemos ambas de alienan y retroalimentan). Esta idea del bautismo como liberador y como otorgador de ciudadanía nos parece de tremendo interés y nuclear de esta imbricación entre cristianismo y republicanismo de la que venimos hablando a lo largo de esta tesis. Afirma Cartagena: «Ninguno, pues, ya sea israelita, ya sea gentil, será excluido de los dones de Cristo ${ }^{499}$.

De acuerdo al Defensorium, la potencialidad de la salvación, entendida como entrada en la república cristiana, es dada a todos mediante la gracia, independientemente de esencialismos su origen. Y, como decimos, no opera sólo en el ámbito de lo trascendente, sino también en lo político: la salvación que otorga el bautismo permite ser ciudadano, ejercer como tal. Afirma, Cartagena en esta dirección: «Y como por la gracia del bautismo se convierten en ciudadanos miembros de la familia de Dios y de los santos (...) por este decreto establecemos que los de aquellas ciudades y lugares en donde son regenerados por el santo bautismo gocen de los

${ }^{499}$ Cartagena (1993): 179. 
privilegios, libertades y exenciones que otros consiguen solamente por razón de nacimiento y de origen ${ }^{500}$.

Esto es, el bautismo deviene una suerte de "salvoconducto" de acceso al ámbito de la libertad, un liberador de servidumbre. No creemos que sea aventurado pensar que alguna impronta de esto hay en la comprensión también instrumental del bautismo en el derecho de gentes del siglo XVI. Respecto a esta cuestión de la libertad, hay que resaltar asimismo el interesante vínculo de ésta con la idea de la unión, de lo comunitario, presente trasversalmente a lo largo del Defensorium: para Cartagena la libertad se encuentra también al superar el yugo de la separación de los pueblos, pues una comunidad cristiana unida en la salvación, es una comunidad que ha aceptado el mensaje igualitario y liberador de la revelación y la redención. La libertad que aportan éstas implica también un mensaje de equidad, pues a todos les es concedida.

Es interesante señalar también que Cartagena rechaza las conversiones forzadas. En su crítica al bachiller Marcos García de la Mora — quien, recordemos, redacta los estatutos de limpieza de sangre contra los conversos-, le increpa: «(...) verías que claramente las leyes anteriormente citadas no concluyen en nada, al prohibirles sus prácticas, cosa la que Iglesia pacientemente tolera para de vez en cuando conseguir el fruto de la conversión voluntaria, por eso en unos de los decretos encontrados del cuarto concilio se dice: "y no se haga violencia a ninguno de ellos"》 ${ }^{501}$.

Somos conscientes de que sobrevuela en relación a esta noción de inclusión en Cartagena que venimos señalando una clara problemática, una aparente contradicción que podría erigirse en crítica inmediata a lo que sostenemos: ¿Cómo es posible que nuestro autor elabore un conmovedor alegato por la inclusión al hablar de los conversos y a la vez arengue contra la herejía? ${ }^{502 .}$ ¿Qué sucede: es una inclusión parcial?, ¿sólo vale para los cristianos?, ¿sólo se puede ser ciudadano si se es cristiano? Evidentemente todo esto podría chirriar, parecer un oxímoron.

\footnotetext{
${ }^{500}$ Cartagena (1993): 261.

${ }^{501}$ Cartagena (1993): 333.

${ }^{502}$ Algo que, además, no sólo está en esa obra, sino que es trasversal a sus textos, recordemos por ejemplo sus palabras en De preeminentia: «(...) pues manifiesta cosa es que mi señor el Rey de Castilla continuamente fase guerra contra los paganos e infieles, e por consiguiente es ocupado de fecho en guerra divinal por mandado del soberano emperador que es Dios») Penna (1985): 221b.
} 
En efecto, es complicado encajar para nuestro paradigma de pensamiento actual no teocéntrico el que se realice una apología por la inclusión, pero "dejando fuera" a los que no opten por el bautismo. Creemos que aquí hemos de hacer un esfuerzo por evitar la tentación del anacronismo y entender que estamos ante una cosmovisión escatológica y cristiana. Además, tenemos que entender en Cartagena la noción de comunidad (tanto cristiana, como política) en sentido relacional — esto es, lo que nos dota de sentido intersubjetivamente, lo que nos mantiene unidos empáticamente, lo que nos da una suerte de estatus existencial y político para autoasumirnos entre nuestros pares - y no ver esta idea de comunidad en sentido de "grupo cerrado" excluyente y gregario. En cualquier caso, lo que más nos interesa filosóficamente aquí (y el argumento con el podría contrarrestarse la crítica con la que empezaba este párrafo) es el hecho de que Cartagena elabore una ratio de la inclusión, esto es, nos interesa en sí que lo haga. Y además el cómo diseña esta ratio: mediante un ejercicio de traductibilidad entre republicanismo y teología, configurando así una teología política articulada con un lenguaje de "derechos". Nos interesa el hecho de que plantee la cuestión del "derecho" al acceso a la ciudadanía como algo necesario, y el que encuentre una herramienta para materializar esto que no es esencialista sino, en cierto modo, "agencial". Tal vez pase esta herramienta por lo cristiano, escatológico y mesiánico, pero no es esencialista en cuanto al origen, por tanto se pueden subvertir las exclusiones y conformar comunidad, esto es más importante. Queremos resaltar que nuestro autor se percata de que es necesaria una forma de garantizar la participación civil y de que hay que definir esta nueva totalidad vinculándola a la noción de ciudad.

Además, como ya hemos apuntado en varias ocasiones a lo largo de este trabajo, no podemos quedarnos en una lectura superficial de los textos de Cartagena-ni de ninguno de sus coetáneos- Es decir, no podemos contentarnos con una lectura que no tenga en cuenta que muchos de sus escritos son textos de circunstancia encargados por la Iglesia o el gobierno con una misión concreta, incluso propagandística. Por ello, en los textos de esta época que nos ocupa no siempre es fácil detectar de primeras el pensamiento del autor que lo firma (incluso es frecuente encontrar posturas aparentemente contradictorias en distintos textos de un mismo autor): hemos de ser capaces de hacer una lectura entre líneas, que vaya más allá de ciertos dejes retóricos (sobre todo en fragmentos que se encuentran en dedicatorias, en prefacios o en conclusiones), que conozca la motivación del texto y si es un escrito de encargo (no es lo mismo, 
por ejemplo, un texto de intercambio intelectual con otro escritor o de denuncia de una problemática social, que un texto de loa a un rey; al igual que no es lo mismo, por ejemplo en un género como el diálogo renacentista, quién dice cada cosa). En definitiva, hemos de procurar llegar a una lectura que sea, capaz de depurar dónde está en verdad la voz del autor, y para esto ayuda conocer su pensamiento, sus fuentes, su contexto y su postura ante determinados debates y espacios de controversia de su entorno intelectual.

El bautismo, no sólo activa la ciudadanía, asimismo restituye el honor y protege jurídicamente. Esta cuestión del honor era vital para Cartagena, tanto por la dimensión práctica de que a los conversos, una vez convertidos, se les restituyesen sus privilegios sociales, como, y sobre todo, porque sin el reconocimiento de este honor - que hemos de entender como dignidad ciudadana necesaria para el ejercicio del servicio público - no era posible ejercitar la virtud, ya que ésta, donde puede llegar a su plenitud es en el ámbito ciudadano, en la participación en el vivere civile (de nuevo reverbera aquí el pensamiento republicano). Escribirá Cartagena: «Y como acabamos de decir que en el bautismo se infunden gracia y virtudes, es lógico que el que sostiene que al bautizado, sin culpa propia, se le ha de negar le honor debido (...) necesariamente afirma a una de las dos cosas: o que en el bautismo no se infunden virtudes, lo que va contra la fe católica, o que a la virtud no se le debe el honor, lo que va completamente en contra de la doctrina filosófica y de todo política de gobierno» ${ }^{503}$.

Y continúa ${ }^{504}$ :

No se puede, por tanto, dudar que cualquier israelita, al igual que cualquier otro, una vez limpio del pecado de infidelidad por el agua del bautismo, en la medida que le corresponda será partícipe del honor tanto eclesiástico como civil, de modo que el rústico se sienta igual entre los rústicos, el plebeyo entre los plebeyos, el de pueblo entre los de pueblo, el mercader entre los mercaderes, el soldado entre los soldados, el noble entre los nobles, el sacerdote entre los sacerdotes, y así sin interrupción hasta recorrer todas las escalas del gobierno eclesiástico o político.

Asimismo, en otro pasaje asevera al respecto: «Y si la rehabilitación natal hecha por un príncipe mortal devuelve la pureza libertad del derecho primigenio y natural, ¿acaso no concederá esto

\footnotetext{
${ }^{503}$ Cartagena (1993): 269.

${ }^{504}$ Cartagena (1993): 269.
} 
con más plenitud la misma restitución otorgada por la preciosa sangre del Rey eterno que muriendo destruyó nuestra muerte y resucitando restauró la vida? Incluso la restitución hecha por un príncipe reintegra toda clase de honores» ${ }^{505}$.

Encontramos también reflexiones como ésta ${ }^{506}$ :

¿Qué mayor alejamiento de la vida pasada o qué mayor renovación puede darse, una vez rechazada la infidelidad, que aquella que por medio de la recepción de la fe se produce con la purificación sacramental por la cual surge el hombre nuevo al despojarse completamente del hombre viejo? Del hombre viejo, por consiguiente, no queda impedimento, o mancha, de tal manera que puede alcanzar tanto la salvación del alma como los honores de esta vida, si no hay cosa alguna especial en contra de su persona.

Si no se reconoce el honor, no se reconoce la virtud. Ambos conceptos están asociados a la idea de nobleza, pues ésta se entiende como lo opuesto a la vileza. Cartagena defiende que los judíos no han carecido en absoluto a lo largo de la Historia de personajes ilustres de enorme nobleza, personajes ejemplares que va mencionando y que son representativos de las virtudes de todo un pueblo, y que son, por tanto, prueba de que dicho pueblo es susceptible de albergar también nobleza. Sin embargo, en esta argumentación en favor de la factibilidad de la restitución del honor para los conversos vía el reconocimiento de su nobleza — argumentación en la que emplea la teoría jurídica bartoliana de la triple naturaleza de la nobleza (natural, civil y teológica) - reconoce que los hebreos se han alejado de la nobleza teológica al no adherirse a la buena nueva del cristianismo, y eso ha desencadenado que las otras dos categorías de nobleza queden latentes $^{507}$. Pero latentes no quiere decir inexistentes, pues si se convierten al cristianismo y con ello restituyen la nobleza teológica, las otras dos — esto es, natural y civil— se activarán de inmediato, recuperando así el honor y debiendo poder entonces desempeñar labores civiles.

\footnotetext{
505 Cartagena (1993): 290.

${ }^{506}$ Cartagena (1993): 256.

${ }^{507}$ Esto lo desarrolla en capítulo tercero del teorema cuarto de la segunda parte, explica, por ejemplo «Por otra parte, además, los mismos príncipe e la ley en sus tratados pusieron la nobleza teológica en el reconocimiento divino, la nobleza natural o moral en el ejercicio de la virtudes, situando la nobleza civil en el reconocimiento del que tiene el ejercicio e poder, y en virtud de la cual distingue a alguien sobre los hombres honestos del pueblo (...) Es de sobra sabido pues, que esta triple clase de nobleza la han tenido muchos israelitas antes de su infidelidad, y tantas veces la Sagrada Escritura de testimonio de que algunos ellos fueron agradables a los ojos de Dios, adquiriendo así la nobleza teológica, que no sería justo dudarlo.» Cartagena (1993): 221.
} 
Con esto, Cartagena deja claro que tras la conversión no hay razón para marginación civil de los conversos $^{508}$ :

De donde se infiere que al perder la gracia divina, hayan perdido por completo la nobleza teológica y como resultado de la falta de nobleza teológica hayan obscurecido con gran moho la nobleza natural y civil. Sin embargo, de las noblezas natural y civil, que no difamaron en su origen, sino que difamaron por el adimento de la falta de nobleza teológica, conservan por así decirlo algo como cadáveres. Y como incurrieron en ella como consecuencia de la cólera divina, es lógico que, al cesar la cólera y concedérseles cumplidamente perdón por medio del agua del bautismo, todo este moho desparezca como algo secundario, así como en derecho cuando la condición de lo sustituido depende de la condición de lo establecido, su la condición de lo establecido se destruye por reconocimiento de lo último, inmediatamente conviene que se rompa la condición de lo sustituido que de él dependía (...) Y, al resurgir por la fuerza de la fe aquellos que estaban muertos, no resultará ilógico que como consecuencia vuelvan a la vida los cadáveres de las noblezas que yacían sepultos con ellos (...) Justo es, por consiguiente, que aquellos que tuvieron noblezas las recobren.

Como expone al respecto Fernández Gallardo: «Así, la marginación de los judíos se justificaría sólo por mor de la pérdida de la nobleza teológica; su recuperación mediante el bautismo dejaba expedito el camino para el pleno reconocimiento de su dignidad en la sociedad cristiana» ${ }^{509}$.

Considerando todo lo anterior visto en este punto, podemos entender en toda su plenitud la siguiente afirmación de Cartagena: «De esto se entiende que en el tiempo de la gracia las diferencias de tiempo de la ley serán arrancadas de raíz entre aquellos que recibieron la fe» ${ }^{510}$. En palabras de José Luis Villacañas explicando a Cartagena: «El tiempo de la gracia borra así las diferencias del tiempo de la Ley» ${ }^{511}$. O en los términos de Fernando Miguel Pérez Herranz: «Contra la superstición de la carne — biologismo - , la teoría de la gracia — culturalismo $\longrightarrow{ }^{512}$. En efecto, para Cartagena en el nuevo tiempo inaugurado por la revelación, lo que importa el espíritu y no el origen de la carne (sólo en esta somos diferentes). Es precisamente la aceptación

\footnotetext{
${ }^{508}$ Cartagena (1993): 278 y 280.

${ }^{509}$ Fernández Gallardo (2002): 390.

${ }^{510}$ Cartagena (1993): 136.

${ }^{511}$ Villacañas (2012).

${ }^{512}$ Pérez Herranz (2016): 288.
} 
de la gracia y de la revelación lo que nos garantizará ser verdaderamente ciudadanos, tanto de la república cristiana como de la república civil.

Es más, salvando las distancias diacrónicas, estimamos que hay en esta idea algo de tremenda actualidad: cierta agencia, pues la ciudadanía activa puede adquirirse mediante un acto volitivo (la decisión de bautizarse construye "performativamente" ciudadanía, es como un acto de habla que cataliza la posibilidad de ser ciudadano). Aclara Cartagena $^{513}$ :

Pero aparte de esto también hay que tener en cuenta, que cada uno muestra regresar por su propia voluntad, porque la discusión no es acerca de los muertos que permanecieron bajo la infidelidad, y a quienes no se les puede aplicar el postliminio, sino que la discusión es acerca de los que regresan, quienes, (...) al verse en su condición de libres por la protección del postliminio, inmediatamente se desbordan de alegría (...) De la misma manera también los que entran en los términos de nuestro imperio cristiano por la puerta del bautismo, al conseguir los derechos del postliminio divino se imaginan que jamás han estado bajo el poder de un antiguo enemigo.

\subsection{Reacción ante el uso arbitrario de la autoridad. Desactivación jurídica de los estatutos de limpieza de sangre. Deslegitimación de las políticas de segregación.}

A lo largo del extenso Teorema Cuarto de la segunda parte del Defensorium y con un método casi de fiscal — esto es, con una gran minuciosidad jurídica y filológica - logra Cartagena demostrar la incorrección jurídica de leyes discriminatorias y segregacionistas como son los estatutos de limpieza de sangre contra los conversos, según los cuales había que demostrar que se era "cristiano viejo", que la sangre era "pura" (es decir, que no se descendía de judíos) para poder ejercer cargos públicos y dar testimonio como testigo en un juicio ${ }^{514}$. Para ello, su cuerpo de fuentes jurídicas estará conformado sobre todo el Corpus Iuris Civilis, la Glosa Ordinaria, el Decreto de Graciano y los textos Bartolo. Obviamente, empleará también fuentes bíblicas en su argumentación, tal y como vimos en el primer apartado de este capítulo. Nuestro obispo se nutrirá de su formación como civilista y canonista y atacará los errores formales, las incongruencias y las distorsiones de base de la Sentencia Estatuto encargada por Pedro Sarmiento y redactada por el bachiller Marcos García de la Mora (a quien interpela

\footnotetext{
${ }^{513}$ El término postliminio se refiere a: «En el derecho romano, reintegración de quien había sido prisionero del enemigo a sus derechos de ciudadano romano.», según la definición del diccionario digital de la RAE. Consultado el 7 de enero de 2017 en http://dle.rae.es/?id=TnvRt2n. Cartagena (1993): 289.

${ }^{514}$ Cartagena (1993): 294 y ss.
} 
directamente). Cartagena probará su falta de pertinencia, tanto ética como jurídica. Para hacerlo, concretamente, se acogerá a las equivocaciones del Bachiller en lo tocante al menor principio de autoridad que las conclusiones de un concilio local tiene frente a un Concilio General. Como relata en su texto Cartagena, la base doctrinal a la que Sentencia Estatuto había apelado para legitimarse era el IV Concilio Toledano, celebrado en tiempo de Sisenando, y a cierto privilegio otorgado al respecto "por el cathólico y de gloriosa memoria D. Alfonso, rey de Castilla y León», aunque el Bachiller no especifique exactamente quién era tal rey ni a qué privilegio en concreto se refería. Como explica Fernández Gallardo, «resulta sumamente elocuente la visión historicista que del Derecho Común se ofrece en el Defensorium, donde las Leges feudorum se valoran en función de las circunstancias históricas de su incorporación al Corpus Iuris Civilis» ${ }^{515}$.

El autor de la Sentencia-Estatuto remitía a la ley sexta de dicho concilio, según la cual no es válido el testimonio de los judíos ya que su palabra no es fiable, tal y como no lo es su fe, y aunque se conviertan y se digan cristianos esta sospecha de falsedad permanece. Este decreto del concilio reza: «Non potest erga homines ese fidelis quie Deo exteterit infidelis. Judei, ergo, qui dudum christiani effecti sunt, et nunc Christi fidem prevaricat sunt ad testimonium admitti nos debent, quamvis ese se christianos annuncient, quia sicut in fide Christi suspecti sunt, ita in testimonio humano dubii habentur. Infirmari, ergo, oportet eorum testimonium qui in fide falsi docentur. Neque eis ese credendum quie veritatis a se fidem abjecerunt ${ }^{516}$.

Asimismo, y aquí está el quid del asunto en lo tocante a los conversos, se refería el Bachiller a la ley séptima del mismo concilio por la cual no deberían ostentar cargos públicos los judíos, “o los que fueron judíos”. Así versa: «Precipiente domino ac excellentisimo Sesinando constituit Santum Concilium ut judei aut hii qui ex judeis sunt, officia publica nullatenus appetant, qui sub hac actione christianis injuriam faciunt» ${ }^{517}$.

Esta sentencia había sido reproducida siglos después por Graciano en sus decretos al

\footnotetext{
${ }^{515}$ Fernández Gallardo (2002): 278.

${ }^{516}$ Tomo el texto de la introducción de Verdín-Díaz, que a su vez lo toma de Sáenz de Aguirre, Josephus: Collectio máxima Conciliurum ómnium Hispaniae et novis orbis, cura et studio, Romae, 1696. Tomus secundus, cap. LXIV, p. 489. Verdín-Díaz (1993): 65.

${ }^{517}$ Verdín-Díaz (1993): 65.
} 
establecer doctrina De his quae judaeis prohibetur ${ }^{518}$. Es en las palabras «aut hii qui ex judeis sunt» donde reside el núcleo del asunto. Cartagena recoge el guante y no niega que en el concilio toledano se esgrimiese tal sentencia, pero achaca a García de Mora una errónea y malintencionada interpretación de la misma. Parece reprocharle una falta de rigor y seriedad en el uso de las fuentes. Cartagena de hecho, en un momento del Defensorium - y tal vez como una maniobra para demostrar su solvencia jurídica y su prestigio - recuerda que cuando estuvo en el Concilio de Basilea, allí se manejaban los textos originales para evitar confusiones: «Por eso yo recuerdo haber visto alguna vez en Basilea que cuando se hacían las solemnes disertaciones con la presencia de legado de la sede romana y otros dirigentes con autoridad apostólica, y se exponía algo sacado del libro de Graciano, se traían los libros de donde él lo había tomado, para que, leído íntegramente el texto original, se viese con más claridad lo que su autor había dicho» ${ }^{519}$.

Lo que hará Cartagena es asociar ese «aut hii qui ex judeis sunt», ese "ser judío," no al origen hebraico, no a la carne, sino a la práctica, esto es, al hecho de "judaizar", que es algo de calado espiritual, o sea, es un acto religioso consistente en practicar el judaísmo (a veces ocultamente); práctica que, para Cartagena, en sí es ya herética a partir de la venida de Cristo y la posibilidad de bautismo (no antes). Sin embargo, según nuestro obispo, incluso el ser judío, no es una conducta ligada fenotípicamente al origen hebreo, esto es, no todos los que tienen origen hebreo lo son, y de hecho los conversos no lo son, sino todo lo contrario, precisamente por haber elegido la conversión. Por ello los conversos, en la medida en que no judaízan, no son judíos. Sostiene Cartagena que lo que verdaderamente le hace a uno judío, no es su origen, sino el acto de judaizar. Así como un no hebreo de origen, puede judaizar. Éste el meollo de la cuestión: los conversos han dejado de ser judíos, no en cuanto al origen de su carne, pero sí en lo espiritual, por ello, para Cartagena, la sentencia que emplea el bachiller Marcos García de la Mora no tiene validez para los conversos. La identidad se vincula a las creencias, no al origen. Como apunta el burgalés, la cuestión se trata de «una adherencia del espíritu y no a una genealogía carnal» ${ }^{520}$. Afirma, interpelando al Bachiller ${ }^{521}$ :

\footnotetext{
${ }^{518}$ Benito Ruano (2001).

${ }^{519}$ Cartagena (1993): 297.

${ }^{520}$ Cartagena (1993): 328.

${ }^{521}$ Cartagena (1993): 307.
} 
Por medio de lo cual se hace ver patentemente que "ex illus" se dice de los que se juntan a ellos siguiendo su condición, pero no en cuerpo, sino en espíritu (...) Por tanto, movido por tantos ejemplos, comprende que estas palabras, "hii qui ex judeis sunt", se dijeron de aquellos que, ya desciendan de ésta o aquella familia, se unen a la infidelidad de los judíos, por eso lo dijo [Graciano y el concilio] bajo la forma del tiempo presente "sunt", porque no dijo fueron, sino son. Es evidente que no son de los judíos los que, descendiendo de ellos por la sola carne, mantienen la fe católica, o, por mejor decir, están muy lejos de los judíos, porque no hay mayor alejamiento que el alejamiento del corazón.

Y un poco más adelante explica: «En conclusión, a éstos no se les debe llamar judíos bautizados, cuando ya no son judíos, porque este nombre no será por razón de un pedazo de tierra, sino como consecuencia del modo de vivir, como poco antes he especificado. Por lo tanto se les llama judíos bautizados a los que después del bautismo volvieron a caer en el condenado error del judaísmo» ${ }^{522}$.

Escribe al respecto el estudioso Eloy Benito Ruano ${ }^{523}$ :

Don Alonso alega en favor de esta interpretación el recto uso, en tal sentido, que personalmente viera hacer de dicho decreto en el Concilio de Basilea, al que asistió, y el códice fidedigno que allí tuvo ocasión de copiar de los cánones conciliares toledanos, al que estima superior en pureza a los libros análogos conservados en España. En cuanto al valor doctrinal de las constituciones del IV Concilio - no universal, celebrado sin asistencia del legado pontificio, convocado en época de persecución judaica, precisaexpone a su vez sus reservas

Le explicará eficazmente nuestro autor Marcos García de la Mora, en relación con la noción de cristiano nuevo, cómo ha de interpretarse la expresión "de novo": ésta sería aplicable a todos, pues nadie nace bautizado y es el bautismo lo que marca la pertenencia a la cristiandad, no la raza, por ello la distinción entre «cristiano nuevo» $\mathrm{y}$ «cristiano viejo» no tendría sentido alguno teológicamente ${ }^{524}$.

Como otro elemento para argumentar acerca de lo incongruente que es estigmatizar a los conversos como grupo, está la crítica de Cartagena a la propia lógica de los estatutos de limpieza

\footnotetext{
${ }^{522}$ Cartagena (1993): 336.

${ }^{523}$ Benito Ruano (2001).

${ }^{524}$ Cartagena (1993): 319 y 320.
} 
de sangre. Éstos, para pretender legitimarse, parten de la premisa —inaceptable jurídica, moral y teológicamente - de la dimensión hereditaria del pecado, es decir, se basan en que las aparentes faltas que cometieron los antepasados judíos de los cristianos nuevos y que estos últimos las siguen portando. Nuestro autor se preocupa por aclarar que el pecado no es algo que se transmita generación tras generación, como si de una mácula perpetua se tratase, que, además, todo un grupo humano no pudiera superar (clara lógica del racismo y la exclusión como suerte de "males necesarios"). Cartagena cree en la individualidad esencial de la persona a este respecto: los pecados son propios, no colectivos, algo que encaja con la idea cristiana de la unidad esencial y mística entre los cristianos pero manteniendo la idea de pluralidad de individuos (de ahí que puedan formar parte de la comunidad cristiana individuos de distinta procedencia).

Es obligado mencionar en este punto también cómo el autor del Defensorium tilda de herético al Bachiller (es más, le culpa de la peor herejía imaginable, que consiste precisamente en querer fragmentar la natural y mística unidad cristina). Cartagena acusa de herejes a los rebeldes toledanos por el rechazo de éstos a los conversos — rechazo que implica la ruptura de la unidad cristiana, que es la mayor herejía, aberración y atentado contra la paz social—. Y el crimen que les achaca no es sólo religioso, sino también civil, pues implica esta quebrar la unión de la república cristiana, la subsiguiente quiebra de la comunidad política. Y no sólo esto, le recrimina también Cartagena a García de la Mora, que su Sentencia-Estatuto representa un crimen de «lesae maiestatis», no solamente por su desobediencia al monarca, sino por su mismo carácter herético, pues quien comete una herejía contra la cristiandad, la comete también contra el rey, ya que éste que es vicario de Cristo; se explicita así el vínculo para Cartagena entre herejía y ofensa al rey ${ }^{525}$. También, precisamente para fortalecer esta acusación de herejía a dichos insubordinados, y para exacerbar la magnitud de su delito moral y político, y lo justo de su castigo, le conviene a Cartagena potenciar la dimensión providencial del monarca, ya que atentar contra su autoridad, es también hacerlo contra la de Dios. Así lo enuncia ${ }^{526}$ :

Realmente lo que no hay que considerar como cosa nueva es que los que se rebelan contra Dios se rebelen también contra los príncipes, y los que se enfrentan a la soberanía

\footnotetext{
${ }^{525}$ Para ampliar información sobre los crímenes de lesa majestad, véase Pérez Caballero (2017).

${ }^{526}$ Cartagena (1993): 366. El traductor usa aquí el término «soberanía», sin embargo, dado que éste resulta anacrónico teniendo en cuenta el momento en el que este texto es escrito, creemos que hubierse sido preferible emplear «autortidad», o bien «potestas».
} 
del príncipe fácilmente llegan al pecado de herejía, como que los delitos de herejía y de lesa majestad se tocan, o por lo menos están tan extremadamente inmediatos que o uno y otro llegan a encontrarse, o que el paso del uno al otro y del otro al uno se hace con tanta facilidad, que no diré que se den juntos siempre, pero sí muchas veces.

Al monarca lo arenga Cartagena a tomar medidas contundentes al respecto, a castigar a quienes quieren crear un cisma, a quienes «quieren romper reviviendo diferencias anuladas por Cristo», pues no sólo es tarea papal el salvaguardar la cristiandad, sino asimismo lo es del monarca (aunque deja claro nuestro obispo que es el Papa quien tiene prioridad en estos asuntos $)^{527}$. Además, recuerda al rey cómo en la historia de Castilla otros monarcas apoyaron siempre a los conversos - al igual que él, Juan II, reconoce nuestro autor-. Cita Cartagena por ejemplo a Alfonso X el Sabio, o al propio Enrique III, padre de Juan II ${ }^{528}$. De esta exhortación podemos sustraer de nuevo la ósmosis entre las esferas política y religiosa, ya que Cartagena no duda de la potestad de intervención del rey en cuestiones como la de la problemática conversa y la de la necesaria defensa de la unidad cristiana, pues sin ésta ni hay paz ni será factible el bien común.

Acerca de la excelencia del trabajo jurídico de Cartagena en este texto el célebre medievalista Albert Sicroff afirma: «Hizo un estudio [Cartagena] tan profundo que durante dos siglos los abogados de los cristianos nuevos no encontraron nada que añadir a las consideraciones teóricas expuestas en el Defensorium» ${ }^{529}$. En definitiva, Alonso de Cartagena logra desmotar la validez jurídica, teológico-apologética y ética de esta medida segregacionista. Sin embargo, pese a esto, todo pareció resultar en vano, como explicamos en punto 4.1 del presente capítulo, el daño ya estaba hecho y acabaría imponiéndose en Castilla la lógica de la exclusión, lo que impidió la consolidación de una sólida base comunitaria que deviniese comunidad política.

En realidad, lo que más nos interesa hacer notar en este punto, más allá del profundo conocimiento jurídico de Cartagena, es su apuesta por el Derecho para compensar un atropello disfrazado de legalidad como son dichos estatutos. Su confianza en que una arbitrariedad tal no podrá ser legitimada, en que tamaño exceso en el uso de la autoridad no podrá ser aceptado (de

\footnotetext{
${ }^{527}$ Cartagena (1993): 373 y Cartagena (1993): 375.

${ }^{528}$ Cartagena (1993): 273 y 274.

${ }^{529}$ Sicroff (1985): 61.
} 
nuevo en esto emerge el constitucionalismo de Cartagena). En el Defensorium, quizá para tratar de compensar tan gran injusticia, nuestro autor realiza una profunda y hermosa reflexión sobre necesidad de unidad del género humano, sobre la inclusión como forma de convivencia y proyecto político, sobre el universal derecho a la participación y sobre la importancia de la idea comunidad. Es loable su sensibilidad ante la amenaza de la exclusión, su tomar conciencia de la necesidad de igualdad y el paso político de buscar un "instrumento" para materializarla: en su caso el bautismo entendido como elemento de acceso a la ciudanía.

\subsection{Impronta y marginación del pensamiento de Cartagena.}

Alonso de Cartagena, como hemos venido afirmando, fue una figura clave durante el siglo XV, tanto castellano (siendo líder la élite intelectual de Castilla, además de influyente hombre de Iglesia y de Estado), como europeo (recordemos su relevante participación en el Concilio de Basilea, o sus estrechas relaciones con importantes humanistas y con la curia). Sin embargo, a lo largo del siglo XVI en España iría imponiéndose un pensamiento oficial que aislaba y condenaba a los conversos, de ahí que su proyecto político — integrador, republicano- perdiese fuelle.

El programa político de Cartagena explicitado en el Defensorium unitatis christianae no logró hacerse un hueco, finalmente los Reyes Católicos — sobre todo Fernando — se regirían por el proyecto excluyente de los cristianos viejos más reaccionarios.

Paradójicamente, como parte de la ironía trágica de la que está atravesada la modernidad hispánica, un pensador como Cartagena, caería prácticamente en el olvido, tal vez en un olvido deliberado. Dolorosamente, uno de los mayores promotores de la inclusión, uno de los constructores de una ratio política de tintes cívicos basada en la creación de una base comunitaria, todavía no tiene su lugar en la filosofía política. Como recuerda con amargura José Luis Villacañas ${ }^{530}$ :

Que aquél que mencionaba la patria como última palabra tuviera que ser olvidado, tachado, borrado de la memoria por el poder de su propia Castilla, y que su gente y sus amigos, sus herederos y sus discípulos perseguidos y condenados en la misma tierra cuyo

\footnotetext{
${ }^{530}$ Villacañas (2012): 94.
} 
programa de convivencia había diseñado y pensado, hasta el punto de que no quedara de ellos sino los fragmentos de una existencia rota, es sin duda el destino más tenebroso de cuantos han vivido los pueblos modernos. Justo por la ruptura de esta tradición, Castilla, y con ella España, no sólo no ha podido pensarse entera, sino que se acostumbró demasiado pronto a vivir estableciendo divisiones continuas en su seno, divisiones de las que siempre resultaban beneficiados los más brutales y consecuentes a la hora de establecerlas y mantenerlas

Se lamentan también otros autores que nos han acompañado a lo largo de este capítulo, dirá Eloy Benito Ruano: «Sorprendentemente, sin embargo, la torpe defensa de ésta [la sentencia-estatuto] por Marquillos de Mazarambroz iba a ser homologada y puesta en línea (...) con los hitos o monumentos de una corriente de opinión que pronto encontraría amplios ecos en Castilla, haciendo del Estatuto inspirado por el de Mora precedente y cimiento válidos de sí misma ${ }^{531}$. Por su parte, Luis Fernández Gallardo afirma: «Y, sin embargo, a pesar de la imponente construcción intelectual, alzada sobre sólidos fundamentos escriturarios y jurídicos, con que se pulverizaban los argumentos discriminadores, el odio anti-converso prevalecería sobre la razón (...) Los estatutos de limpieza de sangre acabaron imponiéndose, dando lugar a una grave fractura social en la España Moderna» ${ }^{532}$.

Hemos de analizar todavía hoy las consecuencias que generó la anulación de la plena realización del proyecto político y el republicanismo de pensadores conversos castellanos como Cartagena, y la consolidación de un proyecto oficial opuesto: una ratio de la exclusión y la dominación, que es la que finalmente se impuso y detonó ciertas particularidades en la monarquía hispánica, que aunque de fondo débil y con muchos más espacios de autogobierno, parlamentarismo y constitucionalismo de lo que suele reconocerse - como explican expertos como Perry Anderson o Henry Kamen - tuvo formas no inclusivas ${ }^{533}$.

Lo curioso, es que, paralelamente a lo que acabamos de explicar arriba, el legado intelectual de estos lúcidos conversos del siglo XV (con Cartagena a la cabeza), por el contrario, dejaría una profunda huella.

\footnotetext{
${ }^{531}$ Benito Ruano (2001).

${ }^{532}$ Fernández Gallardo (2002): 245-246.

${ }^{533}$ Anderson (1999), Kamen (2014). Uso el término aquí en su acepción de Gramsci.
} 
Creemos que Cartagena jugó un papel primordial en la implementación hispánica del pensamiento republicano en los albores de la modernidad, y en la conformación de sus especificidades, tanto en el ámbito hispano como en el hispánico, esto es, tanto en la Península Ibérica como en Hispanoamérica. A nuestro entender, la impronta de su teología política permea claramente a la Segunda Escolástica (tanto en su manifestación peninsular como americana). Su "republicanismo católico", propio del ámbito hispánico, es una la herencia presente en las controversias sobre la legitimidad de la conquista y en el Derecho de Gentes, esto es, en autores tan relevantes como Francisco de Vitoria, Domingo de Soto, Francisco Suárez, Juan de Mariana, Fernando Vázquez de Menchaca, Fray Alonso de la Veracruz, Bartolomé de Las Casas o en la propia esencia de la Compañía de Jesús — y posterior desarrollo a lo largo de los siglos, de las reducciones jesuíticas a la Teología de la liberación-. Incluso sería interesante pensar en los vínculos y diferencias entre este pensamiento político converso y el desarrollo republicano en autores marranos, sobre todo Spinoza.

En definitiva, queremos reivindicar el papel de Alonso de Cartagena y del pensamiento político converso (o pensamiento republicano converso) en la conformación del llamado pensamiento hispánico. Dentro de esta tradición intelectual, siempre se aplicó con rigor el pensamiento político clásico, el iusnaturialismo y el conocimiento doctrinal con el fin de aplicar las grandes cuestiones teológicas y jurídicas para resolver los problemas socio-políticos circundantes. Los rasgos e importancia de Cartagena y de dicho pensamiento pensamiento político converso los hemos querido mostrar a lo largo de esta tesis.

\section{Conclusiones y aportes del Capítulo 4.}

Tal y como apuntábamos en la introducción a este Capítulo 4, el mismo ha consistido en un análisis del Defensorium unitatis christianae, con el fin de dar un soporte textual a las características planteadas a lo largo de la tesis como intrínsecas y diferenciadoras del pensamiento político converso, satisfaciendo así el objetivo principal de este trabajo, que era el visibilizar dicha manifestación del pensamiento político castellano del siglo XV, y visibilizar también el pensamiento de Alonso de Cartagena. 
A lo largo del capítulo que ahora cerramos, creemos que hemos demostrado que la obra que nos ocupa puede considerarse como paradigmática de uno de los principales rasgos que habíamos identificado como inherentes del pensamiento político converso: la articulación de elementos religiosos con elementos republicanos. Hemos mostrado por qué éste es uno del los textos clave para entender en qué consiste la teología política propia pensamiento político converso que nos ocupa, lo cual implica entender su mismo núcleo.

La parte principal del capítulo, y por ello, el aporte primordial, ha consistido en explicar por qué entendemos este texto como paradigmático del pensamiento político converso y por qué proponemos una lectura original del Defensorium en clave republicana. Hemos sugerido dicha lectura porque sostenemos que en esta obra Cartagena elabora un tratado de teología política del que subyace una racionalidad política de corte universalista que promueve la inclusión y la participación cívica; en su caso, mediante la conformación de una comunidad cristiana que devenga también comunidad política, y conjugando la teleología de la virtud cívica y la teleología de la salvación. Para entender en qué consiste la teología política del texto que nos ocupa, y para dar respuesta a las preguntas que esbozábamos la principio del capítulo — esto es, ¿cómo elabora Cartagena su ratio teológico-política en el Defensorium?, y ¿cómo es la presencia de elementos republicanos en la obra y su articulación con lo religioso? - hemos configurado el análisis de la obra en torno a cuatro ejes : 1) Revisión teológico-histórica de la relación entre judaísmo y cristianismo. Creación de un nuevo pueblo a través de revelación 2) Uso de la metáfora organicista como argumento para la unión, solidaridad y equidad en la república cristiana, 3) Instrumentalización política de elementos teológicos para conformar una ratio de la inclusión y de acceso a la ciudadanía. El bautismo como posibilitador de acceso a la participación cívica. 4) Reacción ante el uso arbitrario de la autoridad. Reacción ante el uso arbitrario de la autoridad. Desactivación jurídica de los estatutos de limpieza de sangre. Deslegitimación de las políticas de segregación. Basándose en estas aristas, hemos promovido esta original lectura del Defensorium unitatis christianae de acuerdo a los aspectos identificados como característicos de lo que hemos denominado en esta tesis pensamiento político converso. Confiamos en que este capítulo haya servido para poner en valor y redimensionar esta obra ligándola a la filosofía política-. 


\section{CONCLUSIÓN}

Tal y como expusimos en la introducción de este trabajo nuestra intención al abordar éste era visibilizar y poner en valor el pensamiento político castellano del siglo $\mathrm{XV}$, reflexionar sobre sus particularidades y acerca de su forma de incorporar valores republicanos, todo ello para poder repensar el relato imperante sobre la implementación de la modernidad política en el ámbito hispano e hispánico. Objetivo justificado como reacción ante la carencia detectada de estudios al respecto y ante la que consideremos una mala, maniquea y superficial interpretación del periodo en el ámbito hispánico, visión sesgada consistente tan sólo en negar que en éste hubiera habido algún lenguaje político más allá del absolutismo, la razón de Estado y la teología imperial (éstos, además, también comprendidos de una manera simplista). Como hemos explicado en esta tesis, normalmente las narrativas académicas hegemónicas han excluido el espectro hispánico de la tradición republicana, cuando, sin embargo, en los siglos XV y XVI hubo de hecho en él un florecimiento de ésta, sólo que con unas características diversas a las de otros lugares. Por ello, con una tesis como ésta pretendemos contribuir a ampliar el relato sobre el pensamiento político europeo en los siglos XV y XVI y a enriquecer la historia del republicanismo. Además, la manifestación del pensamiento político castellano del XV de la que nos hemos ocupado, esto es, lo que hemos denominado pensamiento político converso y cuyo principal rasgo es la imbricación de ideales republicanos con valores de la teología cristiana, sostenemos que tuvo una clara impronta en la Segunda Escolástica en Castilla así como en la elaboración de ésta en los territorios americanos.

Recordemos las preguntas de investigación que abrían este trabajo: ¿De dónde emanan ciertas particularidades de la modernidad hispánica, más allá del relato habitual que han hecho la historia intelectual y la historia de la filosofía política y que explican tales particularidades? ¿Han tenido en cuenta la historia de la filosofía política y la historia intelectual — en su relato de la implementación de la modernidad política - el caso castellano? ¿Cuáles son las características del pensamiento político castellano del siglo XV y quiénes los intelectuales que lo promovieron? ¿Se ha vinculado suficientemente la historia de la filosofía política hispánica con el republicanismo, y se han reivindicado sus manifestaciones propias? ¿Qué contexto determinó las condiciones de posibilidad de que el pensamiento republicano se desarrollase en el caso 
castellano como lo hizo: de dónde y por qué surge, de qué tradiciones intelectuales se nutre, qué problemáticas históricas quería resolver y con qué estrategias? ¿Cómo influyó cierto pensamiento político del siglo XV castellano en la implementación de la modernidad política y en la racionalidad política y teológica en el llamado Mundo hispánico en la modernidad temprana? Creemos que tales cuestiones han sido respondidas transversalmente en la redacción de esta tesis, resumimos ahora cómo se ha llevado a cabo.

Durante el proceso de investigación sobrevinieron ciertos hallazgos y escollos: primeramente el descubrir que la herramienta analítica más comúnmente empleada en la historia de la filosofía política y en la historia del republicanismo en la génesis de la modernidad política, esto es, la categoría de humanismo cívico, tal y como había sido descrita, no encajaba para el caso castellano, algo que se tornaba problemático dado que, como ha podido comprobarse, nuestra postura es que en el pensamiento político castellano del siglo XV hay un clara presencia de valores republicanos. Esto nos llevó a tener que revisitar críticamente en el primer capítulo esta categoría (acuñada por Hans Baron, consolidada por J.G.A. Pocock y utilizada habitualmente por la historia del republicanismo para definir el republicanismo propio del siglo $\mathrm{XV}$ florentino y las bases del republicanismo atlántico de los siglos posteriores) y a tener que acuñar otra denominación para poder describir con más precisión cómo se implementó el pensamiento republicano en Castilla. La prueba demostrada de la no aplicabilidad de dicha categoría de humanismo cívico para nuestro caso de estudio castellano es que en éste, elementos propiamente republicanos se articulan con elementos de la teología cristiana, con la defensa de la monarquía y con la escolástica, factores estos tres que tal categoría de humanismo cívico considera, sin embargo, como no compatibles con la presencia de valores republicanos, hecho que ha implicado que se excluya tradicionalmente al ámbito hispánico de dicha tradición republicana.

Elementos republicanos como la idea de obtención de la virtud a través del desarrollo de la vida activa en el vivere civile (es decir, la noción de participación cívica), la idea de libertad como no dependencia, la apuesta por la equidad, la defensa del origen popular de la autoridad, la conveniencia de poder limitar el uso de la autoridad a quien lo ostenta, o la idea de comunidad política, son elementos todos ellos que en el caso castellano se articulan con nociones teológicas 
como la universalidad de la gracia, la teleología de la salvación, el organicismo místico, o la idea de communitas y pueblo cristianos. Y esta articulación no implica una deflación de la dimensión republicana. Como hemos explicado, no consideramos que una cosmovisión y una filosofía de la historia escatológicas sean para nada incompatibles con la presencia de valores republicanos. Tampoco, como hemos igualmente tratado de demostrar, lo es el apoyo a la institución monárquica, sobre todo si en la concepción de ésta se incluyen elementos como el origen popular de la autoridad (a su vez compatible con un enfoque providencialista de la monarquía, que no es lo mismo que uno teocrático) o la conveniencia del control de la autoridad vía el modelo de gobierno mixto, vía estrategias jurídicas y proto parlamentarias, vía la expectatio y la sinécdoque confusiva propias del organicismo monárquico, o vía la legitimación del tiranicidio. Del mismo modo que la filosofía de la historia no secular no es un impedimento para la participación cívica, ni lo es la existencia de una monarquía, tampoco la epistemología y el lenguaje político propios de la escolástica consideramos que sean óbice para la existencia de pensamiento republicano. Más bien, tal y como hemos expuesto en este trabajo, la escolástica es el formato que estimuló y bajo el cual se elaboró teóricamente el republicanismo castellano del siglo XV.

Todo lo anterior nos ha llevado a plantear también en esta tesis la problemática resultante de que esta categoría de humanismo cívico se haya asimilado totalizadoramente con lo que supuso el pensamiento republicano en el siglo XV, es decir, que se extrapolasen e hipostasiasen las características descritas para el caso florentino y se impusiesen en la historia de la filosofía política como una suerte de "requisitos" para baremar si hubo o no hubo pensamiento republicano y modernidad política. Esta generalización ha llevado a excluir de la historia del republicanismo a contextos como el hispánico, donde dicho pensamiento republicano estuvo presente, pero materializado con otras características e influido por otras variables. Además, tal descripción de humanismo cívico estima que en el republicanismo del siglo XV apenas pervive el pensamiento político medieval y que se recuperan los valores republicanos en el Renacimiento directamente de la Antigüedad clásica, algo acerca de lo que también hemos mostrado nuestra discrepancia, pues en la tradición política medieval sí perviven elementos republicanos (pensemos por un momento en tradiciones como el aristotelismo cristiano, el conciliarismo, el constitucionalismo o el corporativismo medievales). Lo arriba expuesto nos llevó a tomar conciencia de la necesidad de proponer una denominación alternativa para el caso de la presencia 
de elementos republicanos en la Castilla del XV — esto es, de la manifestación política en la que vamos a centrarnos - una denominación que contemplase sus especificidades. La denominación que hemos propuesto en esta tesis es pensamiento político converso (o podría ser también, para ser tal vez más asertivos y concretos, lo que denominaríamos pensamiento republicano converso).

Esta primera problemática que se ha resuelto en el primer capítulo, es decir, la elaboración de nuestra crítica a este concepto de humanismo cívico y la resultante propuesta de una denominación para nuestro caso de estudio, no fue, sin embargo, lo primero que llevamos a cabo en esta investigación, sino que fue resultado de un análisis del contexto intelectual, político, espiritual, cultural, social e histórico de la Castilla del XV, análisis que nos llevó a desvelar las particularidades de dicho contexto y entender cómo fue el pensamiento republicano en él. Esto es, nos condujo a poder entender las condiciones de posibilidad de tal pensamiento político converso, a comprender qué lo determinó, a qué tradiciones y problemáticas respondía, a qué factores estaba intrínsecamente ligado; nos llevó, en definitiva, a poder acotarlo y nombrarlo. Precisamente en la exposición y reflexión de dicho contexto, y en su sistematización en ciertos ejes que hemos estimado son los más relevantes del mismo, ha consistido el segundo capítulo de la tesis, el cual nos ha permitido comprender las característica propias del pensamiento político converso. Estos ejes, analizados en dicho capítulo, son los siguientes: la problemática conversa; la función social del letrado y la idea de servicio público; el papel de la Universidad de Salamanca y de la escolástica en el pensamiento político castellano del siglo XV; la existencia de una religiosidad pre-reformista, paulina, organicista y conciliarista; la particular concepción de la monarquía castellana; y el proyecto de gobierno mixto encarnado por las Cortes castellanas y cuyo clímax fue la Revolución Comunera.

$\mathrm{Al}$ adentrarnos en nuestra investigación en el pensamiento político del XV castellano, sobrevino en seguida la figura de Alonso de Cartagena, figura referida en las fuentes de la época como un líder de la intelectualidad del XV y admirada por sus contemporáneos — tanto castellanos como, por ejemplo, italianos - y presentada como una pieza clave ante la problemática conversa (ligada, como hemos mostrado, a la refundición del pensamiento republicano en Castilla), pero, sin embargo, figura olvidada en la historia de la filosofía 
hispánica. Por ello, nos introdujimos en el estudio de su pensamiento, sobre todo en el abordaje de su pensamiento político, con el fin de recuperar su figura, promover los trabajos acerca de su filosofía política y reivindicar una lectura más profunda y moderna de sus textos, y, asimismo, con el reto de comprobar que los rasgos descritos para el pensamiento político converso del cual estábamos perfilando a Cartagena como uno de sus máximos exponentes, se sustentaban textualmente en su obra cumbre, el Defensorium unitatis christianae. En realidad, el proceso ha sido dialéctico: estudiar a Cartagena nos ha ayudado a poder sistematizar las características de lo que hemos llamado pensamiento político converso, y a su vez, lo que extrajimos de reflexionar sobre el contexto que catalizó a éste y de lo que trazamos como sus rasgos intrínsecos, nos permitió una comprensión más profunda de Cartagena y de cómo se enlazan en su pensamiento los rasgos republicanos, en cómo él los redimensionó articulándolos con elementos teológicos.

El tercer capítulo de este trabajo ha consistido en la presentación de este autor y en la reivindicación de su persona como ejemplo paradigmático del pensamiento político converso, centrándonos en dicho capítulo en exponer algunas de las claves de su pensamiento político sobre todo su noción de servicio público, su aristotelismo cristiano, su conciliarismo, su apuesta por el control jurídico, su concepción de la monarquía y su postura acerca del origen de la autoridad-. Ya su teología política la hemos estudiado en el capítulo cuarto, en el que hemos realizado una lectura en clave republicana del Defensorium unitatis christianae, resaltando la naturaleza de esta obra como un tratado que elabora toda un racionalidad política y teológica. A través de este análisis textual hemos cotejado nuestras intuiciones previas en una fuente de la época, y lo hemos hecho teniendo en cuenta las circunstancias e índice de autoridades que sirvieron como herramientas argumentales al propio autor, intentando así evitar en lo más posible anacronismos o conclusiones sin fundamento textual. Al irnos deteniendo en diversos fragmentos de dicho tratado, hemos ido pudiendo comprobar la hibridación que hace Cartagena entre elementos republicanos y elementos teológicos y cómo promueve una racionalidad política inclusiva, rasgos estos que grosso modo consideramos su mayor aporte y su mayor originalidad.

Mediante el Defensorium, nuestro autor llevó a cabo una traductibilidad cívica de nociones cristianas como la universalidad de la gracia y el bautismo. Su idea de un pueblo que es potencialmente ciudadanía $-\mathrm{y}$ que deviene ciudadanía a través, precisamente, de la 
instrumentalización de estos elementos religiosos que contrarrestan las políticas de exclusión y que permiten la dignificación y la restitución de la virtud cívica al posibilitar el acceso universal a la participación en el vivere civile.- es prueba de ello. La teleología cristiana de la salvación, el amor, la comunión y el bien, y la teleología ética republicana del alcance de la virtud a través del desarrollo de la vita activa en la vida cívica en pro del bien común, la justicia y la libertad se engarzan. Estimamos que esto complementa y torna aun más fértiles los valores republicanos, y no supone por el contrario una pérdida de intensidad de los mismos. Cartagena traslada rasgos de la idea de communitas cristiana (por cuya unidad, cohesión, equidad y fraternidad lucha) a la búsqueda de la consolidación de una base comunitaria que devenga comunidad política. Hemos intentado demostrar en este análisis textual por qué entendemos que esta obra conformó una ratio política inclusiva y promovió para Castilla un proyecto de convivencia - transido de rasgos republicanos - que eliminase la exclusión por esencialismos de origen, que impidiese el auge de leyes segregacionistas y que estimulase el acceso universal a la posibilidad de participación cívica.

Asimismo, hemos querido incidir en la importancia del Defensorium y en general de este pensamiento político converso en la conformación de un proyecto político y social para la implementación de la modernidad política en el ámbito hispánico, proyecto que, pese a no resultar exitoso (constatando su fracaso en la implantación final de los estatutos de limpieza de sangre, la consolidación de un pensamiento oficial marcado por la exclusión y la segregación, o el fracaso del movimiento de las Comunidades), sostenemos que generó una profunda impronta en la historia intelectual hispánica (presente por ejemplo en la Segunda Escolástica, tanto en la Escuela de Salamanca como en su desarrollo americano)

En definitiva, hemos querido reivindicar el papel de Alonso de Cartagena y del pensamiento político converso - los rasgos e importancia de ambos los hemos mostrado a lo largo de la tesis - en la conformación del llamado pensamiento hispánico de la modernidad. Nos referimos con esto a una tradición intelectual que tuvo por bandera - con un notable rigor y dedicación intelectual para explorar en la herencia doctrinal, el iusnaturalismo y el pensamiento político clásico - el aplicar las grandes cuestiones teológicas y jurídicas para resolver los problemas socio-políticos circundantes 
Respecto a la pertinencia de esta tesis, pensamos que se da en dos planos, uno diacrónico y otro actual, por lo que podría resaltarse su labor de mediación. El revisar el tradicional relato de la historia de la filosofía política permite realizar un ejercicio de genealogía crítica de la temprana modernidad hispánica que sirva como mediación para poder entender ciertas inercias, ciertos fracasos y ciertos tornasoles en la asunción de la noción de ciudadanía y de comunidad en el ámbito de lo que son hoy España e Hispanoamérica, obviamente salvando las diferencias entre ambos espacios y, a su vez, entre los distintos países de lo que es hoy Iberoamérica. El que el proyecto político inclusivo y participativo del pensamiento político converso fracasase, implicó consecuencias como la consolidación en el mundo hispánico de una racionalidad política de la exclusión versus la conformación de un comunidad política, la dominación sin hegemonía, o la introyección defectiva de la noción de ciudadanía por parte de las población, rasgos que operan aún en la actualidad.

Y operan hoy día tanto en lo referente al ejercicio del poder por parte de los gobiernos, como en lo referente a la conformación de subjetividades políticas, que se auto-perciben como naturalmente excluidas de la participación política y como no invitadas en a la construcción del Estado, inhibiéndose a la participación política dentro del marco de la institucionalidad y mostrando una falta de confianza en el Estado. Éste, y los distintos gobiernos que ejercen el poder político, son percibidos como dispositivos lejanos y coercitivos, pero no como garantes de derechos que "protegen" y que velan por una existencia igualitaria y armónica entre sus miembros. A su vez, y como consecuencia de esto, los gobiernos se saben poseedores de impunidad y de capacidad de arbitrariedad en el ejercicio de la dominación, pues los grupos dirigentes presuponen que la población no está empoderada como ciudadanía y no va a interpelarlos. Sin embargo, también esta situación de percepción de que dentro de la institucionalidad no cabe la participación (constatada por la actual crisis de representación tan discutida al hablar de la post-política) ha implicado un florecimiento de los movimientos sociales en pro de la canalización de demandas sociales y de conformación de comunidad política, movimientos que pese a surgir de una forma paralela al Estado, han devenido - aunque pueda parecer paradójico de antemano- una esperanza para el nuevo republicanismo progresista. Nos explicamos: en la medida en la que la población no se encuentra representada en la instituciones, 
las luchas sociales (y con esto nos referimos a las demandas en torno a cuestiones como la violencia, la mala distribución de los recursos, el patriarcado, el racismo, la crisis ecológica, el racismo, etc.) se han aglutinado y organizado al margen del Estado, esto es, en movimientos sociales, y son éstos precisamente los que albergan la potencia crítica pata poder construir nuevos paradigmas en un escenario como la actual crisis del modelo neoliberal, nuevos paradigmas que es deseable que se incorporen luego a la institucionalidad, haciendo así de la participación ciudadana el agente de refundación republicana de las instituciones.

De todos modos, y volviendo a nuestro trabajo concreto, como hemos venido sosteniendo en esta tesis, aunque el proyecto político propio del pensamiento político converso no logró implementarse totalmente, sí lo hizo parcialmente, de ahí que ciertas prácticas republicanas de negociación y control de la autoridad regia se dieran sin duda en el mundo hispánico a través de instituciones como las Cortes o los gobiernos municipales - que de facto actuaron como cuerpos políticos y fueron capaces de elevar sus demandas y defender su cuota de autogobierno-. Pero sobre todo, como también hemos tratado de mostrar en este estudio, los aportes de este pensamiento político converso y de un autor como Cartagena pervivieron como impronta intelectual inspiradora en logros tan relevantes como los realizados por la Segunda Escolástica.

Goza también de pertinencia este trabajo al abordar la cuestión del pensamiento republicano si tenemos en cuenta el interés creciente, ya desde hace unas décadas, en torno al republicanismo y la recuperación de sus valores, interés que ha sido abordado desde la reflexión académica en los espectros de la Filosofía Política y la Ciencia Política. Tanto modelos como el agonístico de la democracia pluralista o los elaborados por autores más cercanos a los modelos deliberativos, toman del republicanismo nociones como la participación o la democratización de las instituciones como caminos de posible solución ante la actual crisis de la representatividad y auge de gobiernos de discurso autoritario. La recuperación de ideales republicanos también ha sido secundada desde las agendas políticas, sobre todo de los movimientos sociales y de partidos progresistas. Ante tal interés actual en torno al pensamiento republicano estimamos que es útil el observar cómo se han abordado y tratado de materializar ciertos tópicos republicanos en otros periodos, entendiendo así, además, los antecedentes de esta tradición, así como sus fracasos. 
En esta investigación hay otro pliegue de pertinencia que estimamos resaltable, y es el hecho de tratar sobre la historia del pensamiento republicano en el ámbito hispánico habida cuenta de la carencia señalada de estudios al respecto (aunque en estos últimos años comienzan a aflorar trabajos surgidos de la inquietud en torno al republicanismo en el ámbito hispánico, tanto ibérico como iberoamericano -interés dentro del cual nos enmarcamos también-). Carencia que estimamos ha de ser cubierta con el fin de hacer más inteligible la historia de nuestro propio pensamiento político y con el fin de hacer más explicables nuestros comportamientos políticos. Algo que nos resulta muy sugerente y necesario ante la frecuente subordinación cultural de la academia española e iberoamericana a categorías conceptuales importadas y que, tal yo como están descritas, no se adaptan ni explican las tradiciones políticas hispánicas, y que, además, por esta misma incomprensión suelen desechar de antemano al ámbito hispánico de tradiciones intelectuales como el republicanismo.

Otra curiosa circunstancia que apuntamos como guiño que puede formar parte de la exposición de la pertinencia de la presente tesis, es que, precisamente, en este año académico 2018-2109 y con motivo de la celebración de los ocho siglos de existencia de la Universidad de Salamanca, se han venido realizando diversas actividades académicas y publicaciones con el fin de visibilizar la importancia de ésta en la historia del parlamentarismo y del republicanismo, así como su contribución — sobre todo a través de los autores inscritos dentro de la conocida como Escuela de Salamanca, con Francisco de Vitoria como figura más sobresaliente-.

Pensamos también que este trabajo - lo aprendido de Alonso de Cartagena— puede ser útil en ciertos debates actuales, sobre todo, como decía arriba, los resultantes de nuestra incapacidad de generar espacios integradores. Así, por ejemplo, el generado por la tan contemporánea problemática de sistemático rechazo y exclusión por parte de los Estados de personas de otras razas y religiones, personas que se asumen como un otro temible y ante el cual ciertos gobiernos pretenden justificar reacciones injustas, inmorales y autoritarias, siendo un ejemplo paradigmático de esto que decimos el trato al tipo humano del migrante, al que se le niega un trato digno y la categoría de ciudadano. Pues bien, pese a sus limitaciones y tratando de evitar anacronismos, las ideas de fondo de promoción de la inclusión y la convivencia, de necesaria conformación de una base comunitaria unida e integradora, y de la universalidad en el 
acceso a la ciudadanía que promueve el Defensorium unitatis christianae, nos parecen muy rescatables y pertinentes hoy día. También lo es su idea de comunidad cristiana, una idea de comunidad de la cual podría ser tal vez interesante tomar algunos rasgos en el debate sobre la post-secularidad, y de la que, asimismo, que podría ser útil así trasladar algunas características a lo secular. Esto es, Cartagena vincula la idea de comunidad política a una unidad fraternal, mística y de cohesión esencial, y a un enfoque de universalidad, conceptos que podrían trasladarse en lo secular y actual bajo ideas como la empatía, la solidaridad o la vocación de inclusión en la conformación de la comunidad política. Su concepto de comunidad es relacional y abierto, no excluyente; va más allá de lo identitario. Y la idea de comunidad como lo conformador de cohesión social, promueve un vínculo fraterno y universal (algo muy útil también en debates actuales, como, por ejemplo, el del cosmopolitismo frente a los nacionalismos, o el de las antropologías ultra-individualistas, o el de los nuevos sujetos políticos).

Puede ser útil asimismo este trabajo para evitar hacer escisiones apriorísticas en nombre de la secularidad que aseveren que no es posible que existan elementos republicanos en una cosmovisión religiosa (actitud esta última que impide comprender ámbitos como el de la modernidad hispánica, o incluso ciertos ámbitos hoy). Es decir, puede ayudar a quitar cierto estigma sobre la idea de teología política, que suele pre-asumirse como retrógrada o imperial, revisión necesaria en un ámbito como el latinoamericano donde ha habido una larga tradición de lucha social progresista contra el autoritarismo de los gobiernos y en pro de la participación, la justicia social y la inclusión de los oprimidos con un fondo de ética religiosa.

Otro rasgo rescatable en relación con la cuestión de la pertinencia diacrónica de esta investigación es reparar en cómo Cartagena rebate con argumentos jurídicos en el Defensorium contra la arbitrariedad en el uso del poder a la hora de instaurar políticas de exclusión motivadas por esencialismos de origen o por creencias religiosas, y no se refiere nuestro autor sólo una arbitrariedad coercitiva sin más, sino también a aquella que tiene la pretensión de justificarse y legitimarse jurídicamente como una ley cabal, pese a su injusticia moral (en el caso del Defensorium la ley que pretende instaurar los estatutos de limpieza de sangre y excluir con ella a conversos y judíos de la vida civil), algo que también nos resulta muy contemporáneo; pensemos 
de nuevo, por ejemplo en las leyes migratorias contra los refugiados o en las leyes patriarcales que discriminan a las mujeres: en ambos casos se excluye en base a un esencialismo.

El principal aporte de esta tesis ha querido ser el visibilizar el pensamiento político castellano del siglo XV y demostrar que en éste hay elementos de cariz republicano, refundidos sugerentemente con elementos teológicos. Hemos querido también reivindicar la necesidad, resultante de lo anterior, de incorporar esta manifestación que hemos denominado pensamiento político converso (o pensamiento republicano converso), y a un autor como Alonso de Cartagena, en el en relato que la historia de la filosofía política ha hecho sobre la modernidad política, y, asimismo, incorporar al ámbito hispánico en la historia de la tradición republicana, enriqueciéndola así y permitiendo comenzar a hacer a una relectura de ésta.

Dentro de este campo que hemos anhelado contribuir a desarrollar, y en el que ya otros autores están trabajando hace tiempo, es donde creemos que pueden encuadrarse futuras investigaciones vinculadas con la presente tesis: por ejemplo el analizar bajo esta lectura republicana a otros autores castellanos de los siglo XV y XVI, en los cuales en este trabajo no hemos podido ahondar, ello con el fin de poder completar y enriquecer el elenco de lo que hemos catalogado como pensamiento político converso. Pensamos en autores como Fernán Pérez de Guzmán, Lope Barrientos, Enrique de Villena, Juan de Torquemada, Juan de Segovia, Íñigo López de Mendoza, Alfonso Fernández de Madrigal 'El Tostado', Diego Arias Dávila, Rodrigo Sánchez de Arévalo, Alfonso de la Torre, Pero Díaz de Toledo, Diego Valera, Gómez Manrique, Fernán Díaz de Toledo, Alonso de Palencia, Pedro Díaz de Toledo y Ovalle, Diego Rodríguez Almela, Pedro de Osma, Fernando de Roa, Hernando de Talavera, Juan de Lucena, Fray Alonso de Oropesa, Fernando del Pulgar, Juan Arias Dávila, Antonio de Nebrija, Francisco Ramírez, Fray Ambrosio Montesino, Alfonso Ortiz, Diego Ramírez de Villaescusa, Pascual de Aranda, Alonso de Castrillo, o Pedro López de Ayala, entre otros.

Otra sugerente veta de investigación sería el estudiar cómo en el espacio municipal y corporativo se implementaron, durante la temprana modernidad en el espectro hispánico, los principios republicanos y de monarquía mixta. Sigue siendo necesario también ahondar en cuestiones como la comprensión de la monarquía en la Castilla del siglo XV, pues aún su 
organicismo, su profetismo y su providencialismo siguen siendo malinterpretados y confundidos con una defensa del absolutismo y la teocracia.

Incluso sería sugerente explorar en los vínculos y diferencias entre este pensamiento político converso y el desarrollo republicano en autores marranos, sobre todo Spinoza, ya que las figuras claves de ambos provenían de una misma matriz intelectual y cultural: la semítica hispánica. Asimismo, una fértil investigación derivada de la que ahora concluye, sería el analizar la herencia de esta hibridación entre elementos teológicos y republicanos presentada (sobre todo la idea del bautismo como garante de ciertos derechos y otorgador de cierto nivel de ciudadanía e inclusión) en el contexto de las controversias sobre la legitimidad de la conquista detonadas por la conquista de América. O estudiar la huella de dicha hibridación en la concepción teológica y normativa de la noción del bautismo en la conformación intelectual del tipo humano del evangelizador (tenemos en mente al decir esto, por ejemplo a figuras como Fray Antonio de Montesinos o Bartolomé de Las Casas). O ahondar en la impronta de la articulación entre lo cristiano y lo republicano en la constitución del pensamiento político jesuítico en América (en el que, desde las reducciones jesuíticas hasta la teología de la liberación del siglo $\mathrm{XX}$, ha permanecido este engarce, y en el que no parece casual que durante el siglo XVI hubiese una fortísima presencia conversa). Además, lo aportado en este trabajo en torno a la noción de comunidad y sobre la accesibilidad a la misma, puede contribuir a la reflexión filosófica actual acerca de la noción de 'comunidad política'.

En definitiva, esta tesis doctoral está encuadrada en un objetivo macro que, a pesar de parecer evidente, tiene aún mucho trabajo por delante: el visibilizar y reivindicar que en el ámbito hispánico en la génesis de la modernidad se desarrollaron los valores republicanos y el estudiar con qué particularidades se implementó dicho pensamiento republicano. 


\section{BIBLIOGRAFÍA}

\section{FUENTES PRIMARIAS}

\section{Archivos consultados}

Biblioteca Nacional de España B.N.E.

Biblioteca de la Universidad de Salamanca B.U.S.

\section{Fuentes primarias de Alonso de Cartagena ${ }^{534}$}

Traducciones:

1. Libro de Tulio de Senetute, Libro de Tulio de los ofiçios (1422). De la providencia de Dios, De la clemençia, y Pro Marcello (entre 1422 y 1427).

Libros de Tulio: De senetute, De los ofiçios. Edición y prólogo a cargo de María Morrás (1996). Alcalá de Henares, Universidad de Alcalá.

De officiis. Edición y estudio a cargo de María Morrás (1993). Barcelona. Universitat Autònoma de Barcelona.

De officiis. Edición y estudio a cargo de José Luis Villacañas. Biblioteca Saavedra Fajardo de pensamiento político hispánico. Recurso electrónico disponible en: http://www.saavedrafajardo.org/Archivos/LIBROS/Libro0165.pdf

2. De invetione. La Rethórica de Tulio M. Cicerón. (según los estudiosos la datación oscila entre 1421 y 1433$)$.

\footnotetext{
${ }^{534}$ Para un mayor detalle sobre las diversas ediciones y la compleja transmisión textual de las obras de Alonso de Cartagena, sugerimos se consulte MORRÁS, María (1991): "Repertorio de obras, mss. y documentos de Alfonso de Cartagena (ca. 1384-1456)", en Boletín Bibliográfico de la Asociación Hispánica de Literatura Medieval, cuaderno bibliográfico núm. 5, pp. 213-245.
} 
Edición a cargo de José Luis Villacñas: De Inventione Retorica. Biblioteca Saavedra Fajardo de pensamiento político hispánico. Recurso electrónico disponible en http://www.saavedrafajardo.org/Archivos/LIBROS/Libro0164.pdf Edición de MASCAGNA, R. (1969): La Rethórica de M. Tullio Cicerón. Napoles.

3. Tractados y Tragedias. Compilación de traducciones de textos de Séneca publicados bajo este título (entre 1428 y 1434).

Ediciones parciales. Véase Morrás (1991): 222-223

Obras propias:

4. Memoriale virtutum (1425).

Edición y traducción castellana a cargo de M. Campos Souto (2004): El Memorial de virtudes: la traducción castellana del Memoriale virtutum de Alfonso de Cartagena. Burgos, Ayuntamiento de Burgos.

5. Controversia Alphonsiana (o Declinationes contra novam translationen «Ethicorum», o Declinationes super translationem Ethicorum cum Leonardo Aretino, o tamibén Liber Alphonsi episcope Burgensis contra Leonardum inuehentem conta libros Aritotelis (1430 - 1432).

Edición a cargo de T. González Rolán, A. Moreno Hernández y P. Saquero (2000): Controversia Alphonsiana. Madrid, Ediciones Clásicas.

6. Repetitio sobre la ley Gallus, o Tractatus super legem Gallus, o bien De postumis instituendis vel exheredandis. Lección pública pronunciada el 19 de julio de 1434 en Aviñón.

Catedral de Burgos, Ms. 11. No hay ediciones modernas.

7. De Preeminentia (1434). 
Traducción castellana hecha por el propio Cartagena como Discurso sobre la precedencia del rey católico sobre el de Inglaterra en el concilio de Basilea (1434).

Edición a cargo de Mario Penna (1959): "Discurso sobre la precedencia del rey católico sobre el de Inglaterra en el concilio de Basilea”, en Prosistas castellanos del siglo XV, vol. I. Madrid, Ediciones Atlas, pp. 205-233.

8. Sermo habitus in concilio Basilensis per Alphonsum decanum Compostelanum oratorem serenissimi regis Cadtelle in solempnitate sancti Thomas de Aquino (1435).

Biblioteca Vaticana, mss. 232. No hay ediciones modernas.

9. Sermo quem fecit reverendus pater Alfonsus electus Burgensis in sacro Concilio Basiliensis in festo Omnium Sacntorum. Sermón pronunciado el 1 de noviembre de 1435 en Basilea.

Biblioteca Vaticana, mss. 232. No hay ediciones modernas.

10. Allegationes super conquesta Canariae de Alfonso de Cartagena (1436).

Edición a cargo de T. González Rolán, F. Hernández González y P. Saquero (1994): Diplomacia y humanismo en el siglo XV: edición crítica, traducción y notas de las Allegationes super conquesta Insularum Canariae contra portugalenses de Alfonso de Cartagena. Madrid, UNED.

11. Discurso del obispo de Burgos a Alberto II (1438).

Edición y traducción a cargo de Cristina Sánchez en Biblioteca Saavedra Fajardo de pensamiento político hispánico. Recurso electrónico disponible en:

http://www.saavedrafajardo.org/Archivos/LIBROS/Libro0055.pdf

12. Epistula directa ad inclitum et magnificum virum dominum Petrum Fernandi de Velasco Comitem de Haro (h. 1440). 
Edición de N.H. Lawrence (1979): en Un tratado de Alonso de Cartagena sobre la educación y los estudios literarios. Barcelona, Universidad Autónoma de Barcelona.

\section{Doudenarium (1442).}

Editado parcialmente en Gerard Breslin (1989): "The Duodenarium of Alonso de Cartagena: A Brief Report on the Manuscripts and Contents", en La Coronica, 18, pp. 90-102.

14. Qüestion fecha por el noble y magnifico señor don Íñigo López de Mendoza, Marqués de Santillana y Conde del Real, al muy sabio y noble perlado a don Alfonso de Cartagena, Obipso de Burgos. Respuesta del venerable y sabio señor don Alfonso, Obispo de Burgos, a la cuestión hecha por el magnifico señor Marqués de Santillana (1444).

Edición a cargo de Ángel Gómez Moreno (1985), en El Crotalón, núm. 2.

Edición a cargo de Rafael Herrera en Biblioteca Saavedra Fajardo de pensamiento político hispánico. Recurso electrónico disponible en: http://www.saavedrafajardo.org/Archivos/LIBROS/Libro0178.pdf

15. Tractatus questionis ortolanis (1443-1447).

Biblioteca de la Universidad de Salamanca, mss. 2619.

16. Doctrinal de caballeros (h. 1444).

Edición a cargo de María José, Liste (1994): Doctrinal de los cavalleros. Santiago, Universidad de Santiago de Compostela.

Edición a cargo de Noel Fallows (2006): en Tratados militares [Selección] de Alonso de Cartagena. Madrid, Ministerio de Defensa, pp. 55-444.

17. Defensorium unitatis christianae (1449). 
Biblioteca Nacional mss. 442.

Biblioteca de la Universidad de Salamanca mss. 2070 (antes en Biblioteca de Palacio como ms. 1642).

Edición latina a cargo de Manuel Alonso (1943). Madrid, Consejo Superior de Investigaciones Científicas.

Edición y traducción castellana a cargo de Guillermo Verdín-Díaz (1993). Oviedo, Universidad de Oviedo.

18. Pastoral sobre las reliquias de Santa Juliana (1453).

Colegiata de Santillana del Mar, ms., doc. 66.

19. Oracional de Fernán Pérez de Guzmán. (1454).

Edición a cargo de Silvia González- Quevedo (1983). El 'Oracional' de Alonso de Cartagena. Valencia. Albatros Hispanofilia.

Edición a cargo de José Luis Villacañas (2005). Murcia, Biblioteca Saavedra Fajardo de pensamiento político hispánico. Recurso electrónico disponible en: http://www.saavedrafajardo.org/Archivos/LIBROS/Libro0161.pdf

20. Apología sobre el salmo "Judica me Deus" (1456).

Edición a cargo Pedro Sainz Rodríguez (ed.) (1983): Apología sobre el salmo "Ludica Me Deus", en Antología de la literatura espiritual española. Edad Media. Vol. I. Madrid, Universidad Pontificia de Salamanca - Fundación Universitaria Española, pp. 618-630. Edición a cargo de José Luis Villacañas (2005). Murcia, Biblioteca Saavedra Fajardo de pensamiento político hispánico. Recurso electrónico disponible en: http://www.saavedrafajardo.org/Archivos/LIBROS/Libro0160.pdf

21. Glosa a San Juan Crisóstomo. Glosa escrita a petición de Juan II (h. 1456). 
Biblioteca Universidad de Salamanca, ms. 1720.

22. Anacephaleosis nempe Regum Hispanorum, Romanorum Imperatorum, Summorum

Pontificum necnon Regum Francorum o Rerum in Hispania gestarum Chronicon Anacephaleosis (1456).

Edición de Yolanda Espinosa (1989): La Anacephaleosis de Alonso de Cartagena: edición, traducción, estudio. Volúmenes 243-289 de Tesis Doctorales. Madrid, Facultad de Filología de la Universidad Complutense de Madrid.

\section{Fuentes primarias de otros autores}

AGUSTÍN, San: La Ciudad de Dios. Edición e introducción de Francisco Montes de Oca (2006). México, Porrúa.

AQUINO, Tomás de: Suma de Teológica. VV.AA. (2001), 5 volúmenes, traducción española. Madrid, Biblioteca de Autores Cristianos. : Comentario de los analíticos posteriores de Aristóteles. Traducción, estudio y notas de Ana Mallea y Marta Daneri-Rebok (2002). Navarra, Eunsa-Ediciones Universidad de Navarra.

: La monarquía. Estudio preliminar, traducción y notas de Laureano Robles y Ángel Chueca (1989). Madrid. Tecnos.

ARISTÓTELES: Politica. Introducción, traducción y notas de M. García Valdés. Revisada por M. ${ }^{a}$ L. Inchausti Gallarzagoitia (2004). Madrid, Biblioteca Clásica Gredos. : Ética nicomáquea. Ética eudemia. Traducción y notas de J. Pallí Bonet. Introducción de E. Lledó. Revisada por Q. Racionero Carmona (2003). Madrid, Biblioteca Clásica Gredos. 
BACHILLER GARCÍA DE LA MORA, Marcos: Memorial (1449) Editado en Eloy Benito Ruano (2001): Los origenes del problema converso. Madrid, Real Academia de la Historia.

BARRIENTOS, Lope de: Contra algunos zizañadores de la nación de los convertidos del pueblo de Israel (1449), de Lope de Barrientos. Editado en el apéndice de Manuel Alonso (1943): edición latina del Defensorium Unitatis Christianae de Alonso de Cartagena. Madrid, Consejo Superior de Investigaciones Científicas, pp. 323, 342.

Biblia de Jerusalén. (1999), Bilbao, Desclée de Brouwer.

BOECIO: La consolación de la filosofia. Edición y traducción de Leonor Pérez Gómez (1997). Madrid, Akal.

BRUNI, Leonardo: History of the Florentine People. Edición y traducción de James Hankins (2001), 3 volúmenes, Cambridge-MA., Harvard University Press. : Laudatio Florentini urbis. Edición de S. U. Baldassarri (2000). Florencia, Sismel Edizioni.

CASAS, Bartolomé de Las: De regia potestate. Quaestio theologalis. En Obras completas. Vol. 12 (1990). Madrid, Alianza.

CASTRILLO, Alonso de: Tratado de República (1521). Editado por José J. Megías Quirós (1992) en: La teoría politica entre la Edad Media y la Edad Moderna. Alonso de Castrillo. Cádiz, Universidad de Cádiz.

CICERÓN: Sobre la república. Introducción, traducción, apéndice y notas de Á. D'Ors. Revisada por A. Fontán (2002). Madrid, Biblioteca Clásica Gredos. : Los deberes. Introducción, traducción y notas de Ignacio Javier García Pinilla (2014). Madrid, Biblioteca Clásica Gredos. : Invención retórica. Introducción, traducción, y notas de Salvador Núñez (1997). Madrid, Biblioteca Clásica Gredos. 
Cortes de los antiguos reinos de Castilla y León. Actas editadas en Manuel Colmeiro (1883):

Cortes de los antiguos Reinos de León y de Castilla. Madrid, Rivadeneyra. Disponible como recurso electrónico en: http://www.cervantesvirtual.com/obra/cortes-de-los-antiguos-reinos-deleon-y-de-castilla--2/ [Consultado el día 16 de febrero de 2017].

Decreto de expulsión de los judíos de Castilla (1492). Editado en Luis Suárez Fernández (1964): Documentos acerca de la expulsión de los judios. Valladolid, CSIC.

DÍAZ DE TOLEDO, Fernán: Instrucción del Relator para el obispo de Cuenca a favor de la nación hebrea (1449). Puede consultarse íntegro en el apéndice de Manuel Alonso (1943): edición latina del Defensorium Unitatis Christianae de Alonso de Cartagena. Madrid, Consejo Superior de Investigaciones Científicas, pp. 343-356.

ESPINA, Fray Alonso de: Fortalitium Fidei (1458). Editado en Biblioteca Virtual Miguel de Cervantes. Recurso electrónico disponible en: http:/www.cervantesvirtual.com/obra/fortalitiumfidei--6/ [Consultado el día 7 de marzo de 2017].

EUGENIO IV, PAPA (1436): Bula ordenando que se respete a los judios de Castilla y León . Edición y traducción a cargo de Cristina Sánchez. Puede consultarse en Biblioteca Saavedra Fajardo de pensamiento político hispánico. Recurso electrónico disponible en: http://www.saavedrafajardo.org/Archivos/LIBROS/Libro0055.pdf

GARCÍA DE SANTA MARÍA, ALVAR: Crónica de Juan II de Castilla. Manuscrito escaneado tomado del archico de Juan de Mata Carriazo. Recurso electrónico disponible en repositorio de fondos antiguos de la Universidad de Sevilla: http://fondosdigitales.us.es/fondos/libros/9099/1/cronica-de-juan-ii-de-castilla/

LUCENA, Juan de: Diálogo sobre la vida feliz y Epístola exhortatoria a las letras. Edición de Jerónimo Miguel (2014). Madrid, Real Academia Española. 
MAIMÓNIDES: Guía de perplejos. Edición de David Gonzalo Maeso (2015), Madrid, Editorial Trotta.

MARIANA, Juan de: Del rey y de la institución de la dignidad real. Editado y traducido por E. Barriobero (1945), Buenos Aires, Editorial Partenón.

NICOLÁS V, PAPÁ: Bula Humani generi inimicus. (1449) Puede consultarse íntegra como Intervención pontifica resolviendo la disputa en el apéndice de Manuel Alonso (1943): edición latina del Defensorium Unitatis Christianae de Alonso de Cartagena. Madrid, Consejo Superior de Investigaciones Científicas, pp. 367-370.

OROPESA, Alonso de: Lumen ad revelationem gentium et gloriam plebis tuae Israel (1465). Editado como Luz para el conocimeinto de los gentiles. Edición y traducción de Luis A. Díaz (1979). Madrid, Fundación Universitaria Española.

PADUA, Marsilio de: El defensor de la paz. Estudio preliminar, traducción y notas de Luis Martínez Gómez (1989). Madrid, Tecnos.

PLATÓN: República. Diálogos Vol. 4. Introducción, traducción y notas por Conrado Eggers (1988). Madrid, Biblioteca Clásica Gredos.

PULGAR, Fernando del: Claros varones de Castilla. Editado por Robert Tate (1985). Madrid, Taurus.

PÉREZ DE GUZMÁN, Fernán: Coplas a la muerte del obispo de Burgos. Loores de los claros varones de España. Editado en R. Foulché (1912-1915): Cancionero castellano del siglo XV. Madrid, Nueva Biblioteca de Autores Hispanos, 19, vol. 1, núm. 288.

SANTILLANA, Marqués de: Obras completas. Editadas por Ángel Gómez Moreno y P.A.M. 1988. Barcelona, Planeta. 
TORQUEMADA, Juan: Tractatus contra madianitas et ismaelitas (Defensa de los judios conversos). Edición, introducción y notas a cargo de Nicolás López y Vicente Proaño (1957): Burgos, Ed. Hijos de S. Rodríguez.

Santa Junta de Ávila. Parte de las actas publicadas en Ramón Peralta (2010): La Ley Perpetua de la Junta de Ávila (1520). Madrid, Actas Editorial.

Sentencia-Estatuto o Sentencia que Pedro Sarmiento, asistente de Toledo, y el Común de la Ciudad dieron en el año 1449 contra los conversos. Editada en un anexo a la edición latina de Manuel Alonso (1943) del Defensorium Unitatis Christianae de Alonso de Cartagena. Madrid, Consejo Superior de Investigaciones Científicas, pp. 357-365.

SOTO, Domingo de: Relecciones y opúsculos Volumen I: Introducción general. De Dominio. Sumario. Fragmento An liceat... Introducción, edición y traducción de Jaime Brufau (1995). Salamanca, Editorial San Esteban.

SPINOZA, Baruch: Tratado teológico-político [selección]. Tratado político. Estudio preliminar y notas Enrique Tierno Galván (2010). Madrid, Tecnos.

SUÁREZ, Francisco de: Defensio fidei III. Principatus politicus o la soberanía popular. Introducción y edición crítica bilingüe a cargo de E. Elorduy y L. Pereña (1965). Madrid, Consejo Superior de Investigaciones Científicas.

VALERA, Diego de (1982): Doctrinal de príncipes (1474). Edición de Silvia Monti. Verona, Universitá.

VERACRUZ, Alonso de la: De dominio infidelium et iusto bello. Sobre el dominio de los infieles y la guerra justa. Edición de Roberto Heredia (2007). México, UNAM - Instituto de Investigaciones Filológicas. 
VITORIA, Francisco de: Relectio de iure belli o Paz dinámica. Introducción y edición crítica bilingüe a cargo de Luciano Pereña, et al. (1981). Madrid, Consejo Superior de Investigaciones Científicas. : Relectio de potestate civil. Estudios sobre su filosofía política. Edición crítica a cargo de Jesús Cordero Pando (2008). Madrid, Consejo Superior de Investigaciones Científicas.

\section{BIBLIOGRAFÍA SECUNDARIA}

ABAD, José (2008): “La «virtù» según Maquiavelo: significados y traducciones”, en Tonos.

Revista electrónica de estudios filológicos, núm. 15, junio 2008, Universidad de Murcia. Recurso digital https://www.um.es/tonosdigital/znum15/secciones/estudios-1-maquiavelo.htm [Consultado el 3 de octubre de 2016].

ABELLÁN, José Luis (1979): Historia crítica del pensamiento español. Madrid. Espasa Calpe. (1976): El erasmismo español: una historia de la otra España. Madrid,

Editorial Gráficas Espejo.

AGAMBEN, Giorgio (2006): El tiempo que resta. Comentario a la Carta a los Romanos. Madrid, Trotta.

AGUILAR, José Antonio y ROJAS, Rafael (2002) (coords.): El republicanismo en Hispanoamérica. Ensayos de historia intelectual y política. México, Fondo de Cultura Económica - Centro de Investigación y Docencia Económicas.

ALBERIGO, Giuseppe (2004): Historia de los concilios ecuménicos, Salamanca, Ed. Sígueme.

ALBIAC, Gabriel (20013): La sinagoga vacía. Un estudio de las fuentes marranas del spinozismo. Madrid, Tecnos. 
ALCALÁ, Ángel (2011): Los judeoconversos en la cultura y sociedad españolas. Madrid, Trotta.

(coord.) (1995): Judios, sefarditas, conversos: la expulsión de 1492 y sus consecuencias. Ponencias del Congreso Internacional celebrado en Nueva York en noviembre de 1992. Valladolid, Ámbito, pp. 89-117.

ALEMÁN, Jorge (2016): "Poder y hegemonía: la diferencia", ponencia presentada el 22 de septiembre de 2016 en la Facultad de Filosofía de la Universidad Complutense de Madrid en el contexto del Congreso Internacional Populismo versus Republicanismo: Genealogía, Historia, Crítica.

ALONSO, Manuel (1943): "Introducción histórica", en su edición latina del Defensorium Unitatis Christianae de Alonso de Cartagena. Madrid, Consejo Superior de Investigaciones Científicas, pp. 17-57.

ALONSO MIGUEL, Álvaro (1984): “Cristianismo y epicureísmo: Fray Alonso de Cartagena y el Libro de la vida bienaventurada”, en Dicenda, núm. 3, pp. 191-197.

ANDERSON, Perry (1999): El Estado absolutista. Madrid, Siglo XXI.

ARANDA, Francisco José y RODRIGUES, José Damião (eds.) (2008): De Re Publica Hispaniae. Una vindicación de la cultura política en los reinos ibéricos en la primera modernidad. Madrid, Sílex.

ARENDT, Hannah (2006): Sobre la revolución. Madrid, Alianza Editorial.

ARTOLA, Miguel (1999): La Monarquía de España. Madrid, Alianza Editorial.

ASENSIO, Eugenio (1952): “El erasmismo y las corrientes españolas afines”, en Revista Española de Filología, 36, pp. 31-99. 
ATTIAS, Aron (2016): "Reseña del libro de Roberto Esposito Dos. La máquina de la teología política y el lugar del pensamiento", en Postdata: Revista de Reflexión y Análisis Político, vol. 21, núm. 2, pp. 598-600.

BADIOU, Alan (1999): San Pablo. La fundación del universalismo. Barcelona, Anthropos.

ALONSO BAELO, Pablo Luis (2007): "El Tratado de República de Alonso de Castrillo. Una reflexión sobre la legitimidad de la acción política”, en Res publica, 18, 475-490.

BAER, Yitzhak (1981): Historia de los judios en la España cristiana. Madrid, Altalena.

BARANDA, Consolación (2004): "La Celestina y el mundo como conflicto. Salamanca, Universidad de Salamanca.

BARON, Hans (1993): En busca del humanismo cívico florentino. Ensayos sobre el cambio del pensamiento medieval al moderno. México, Fondo de Cultura Económica. (1955a): Crisis of the Early Italian Renaissance. Civic Humanism and Republican Liberty in an Age of Classicism and Tyranny. Princeton, Princeton University Press. (1955b): Humanistic and Political Literature in Venice and Florence at the Beginning of the Quattrocento. Cambridge-MA., Harvard University Press.

BATAILLON, Marcel (2000): Erasmo y el Erasmismo. Barcelona, Crítica. (1998): Erasmo y España. México, Fondo de Cultura Económica.

BAYLIN, Bernard (2005): Atlantic Histoy. Concept and Contours. Cambridge-MA., Harvard University Press.

BEAUJOUAN, Guy (1971): “The Converso Community in 15th Century Spain”, en R. D. Barnet (ed.): The Sephardi Heritage: essays on the historical and cultural contribution of the Jews of Spain and Portugal. London, Vallentine. 
BENITO RUANO, Eloy (2001): Los orígenes del problema converso. Madrid, Real Academia de la Historia. (1961): Toledo en el siglo XV. Vida politica. Madrid, CSIC. (1957): "El memorial contra los conversos del bachiller Marcos García de Mora", en Sefarad: Revista de Estudios Hebraicos y Sefardies, Año 17, núm. 2, pp. 314-351.

BERLIN, Isaiah (1969): "Two Concepts of Liberty," in Four Essays on Liberty, Oxford. Oxford University Press.

BLACK, Antony (1992): Political Thought in Europe, 1250-1450. Cambridge. Cambridge University Press.

BLASCO MARTÍNEZ, Asunción (2001): "Razones y consecuencias de una decisión controvertida: La expulsión de los judíos de España en 1492", en Kalakoricos, núm. 10, pp. 936.

BOBBIO, Norberto y VIROLI, Maurizio (2002): Diálogo en torno a la república. Barcelona. Tusquets.

BOCK, Gisela, Quentin SKINNER, Quetin and VIROLI, Maurizio (eds.) (1990): Machiavelli and Republicanism. Cambridge, Cambridge University Press.

BONMARTÍ SÁNCHEZ, Virginia (2006): Humanistas europeos (siglos XIV y XVI). Madrid, Ed. Complutense.

BRADING, David A. (1991): Orbe indiano: de la monarquía católica a la república criolla, 1492-1867. Cuidad de México, Fondo de Cultura Económica.

BRESLIN, Gerard (1989): "The Duodenarium of Alonso de Cartagena: A Brief Report on the Manuscripts and Contents", en La Coronica, 18, pp. 90-102.

BRETT, Annabel (2011): Changes of State. Nature and the Limits of the City in Early Modern 
Natural Law. Princeton. Princeton Universitiy Press.

(1997): Liberty, Right and Nature. Individual rights in later scholastic thought,

Cambridge, Cambridge University Press.

BRUGGER. B. (1999): Republican Theory in Political Thought: Virtuosus or Virtual?

Basingstoke, St. Martin's Press.

BURKE, Peter, GARIN, Eugenio (eds.) (1993): El hombre del Renacimiento. Madrid, Alianza Editorial.

CAMILLO, Ottavio di (1976): El humanismo castellano del siglo XV. Valencia, Fernando Torres.

CAMPOS SOUTO, Marco (2000): "Los sistemas de filosofía moral en el Memorial de virtudes y en el Oracional de Alonso de Cartagena", en Proceedings of the Ninth Colloquim, (Beresford y Deyermond, eds.). Londes, Queen Mary and Westfield College.

CANTERA BURGOS, Francisco (1952): Alvar García de Santa María y su familia de conversos. Historia de la judería de Burgos y de sus conversos más egregious. Madrid, Consejo Superior de Investigaciones Científicas, Instituto Arias Montano.

CAPPELLI, Guido (2014): “'Informe Valera': Fichas y acotaciones sobre Humanismo y política”, en Mosén Diego de Valera. Entre las armas y las letras. Woodbridge. Tamesis, pp. 121.

(2011): "Vida y muerte del humanismo político", en Claves de la razón práctica, núm. 212, pp. 4-11.

(2009): “Conceptos transversales. República y monarquía en el Humanismo político", en Res publica, 21, pp. 51-69.

(2006): “Y lo llaman 'Utopía'. Doctrina y realidad en el humanismo político", en Suplemento Monográfico del Grupo de investigación 'Nomos', Ed. Francisco Lisi Bereterbide. 
CAPPELLI, G. y GÓMEZ RAMOS, A. (2008): Tiranía. Aproximaciones a una figura del poder. Madrid, Dykinson.

CÁRDENAS, Javier y TORREGROZA, Enver (2011):: "La filosofía política de Alonso de Cartagena en su Defensotium Unitatis Christianae" en Revista de Hispanismo filosófico, núm. 16 , pp. 7-25.

CARDONA, Luz Margarita (2011): "La noción republicana de virtud: de la virtud moral a la virtud cívica", en Forum, núm. 2, dic. 2011, pp. 109-126.

CARO BAROJA, Julio (1978): Los judios en la España moderna y contemporánea. Madrid, Istmo.

CARRETERO Zamora, Juan Manuel (1988): Cortes, monarquía, ciudades. Las Cortes de Castilla a comienzos de la época moderna (1476-1515). Madrid, Siglo XXI.

CASTILLO, Jesús Luis (2004): “Aristotelismo político en la Universidad de Salamanca: Alfonso de Madrigal y Fernando de Roa”, en La Coronica, vol. 33, núm. 1, pp. 39-52. (1986): "Las bases filosófico-jurídicas y políticas del pensamiento comunero en la Ley perpetua", en Ciencia tomista, núm. 370.

CASTRO, Américo (1996): La realidad histórica de España. México. Porrúa. (2013): España en su historia: cristianos, moros y judios. Barcelona, Crítica.

CASTILLA URBANO, Francisco (2012): "Patriotismo y legitimación monárquica en el pensamiento de Alonso de Cartagena: los escritos de Basilea", en Revista Española de Filosofia Medieval, núm. 19, pp. 139-157. (2011): "La función de la metáfora organicista en la obra de Alonso de Cartagena", en Ingenium. Revista de historia del pensamiento moderno, 5, pp. 77-103. 
(2010): "La idea del cuerpo místico en Alonso de Cartagena", en El pensamiento político en la Edad Media (Pedro Roche Arnas, coord.). Madrid, Centro de Estudios Ramón Areces, pp. 2010, pp. 355-368.

CASTILLA URBANO, Francisco y VILLAVERDE RICO, María José (2016) (Directores): La sombra de la Leyenda Negra. Madrid, Tecnos.

CELENZA, C. (2004): The Lost Italian Renaissance: Humanists, Historians, and Latin's Legacy. Baltimore and London, The Johns Hopkins University Press.

CENTENERO DE ARCE, Domingo (2012): De repúblicas urbanas a ciudades nobles: un análisis de la evolución y desarrollo del republicanismo castellano (1550-1621). Madrid, Biblioteca Nueva.

CHIGNOLA, Sandro (2009): "Historia de las disciplinas e historia de la filosofía: más allá de Koselleck, Pocock y Skinner", en Historia de los Conceptos y Filosofía política. Madrid, Biblioteca Nueva. (2003): "Historia de los conceptos, historia constitucional, filosofía política. Sobre el problema del léxico político moderno", en Res publica, 11-12, pp. 27-67.

CHIGNOLA, Sandro y DUSO, Giuseppe (eds.) (2009): Historia de los Conceptos y Filosofía política. Madrid, Biblioteca Nueva.

CLAVERO, Bartolomé (1991): Razón de estado, Razón de individuo, Razón de historia. Madrid, Centro de Estudios Constitucionales. (1986): Tantas personas como Estados: por una antropología política de la historia europea. Madrid, Tecnos.

COLEMAN, Janet (2005): "El concepto de república. Continuidad mítica y continuidad real”, en Res Publica, n. 15, pp. 27-47. 
COLMEIRO, Manuel (1883): Cortes de los antiguos Reinos de León y de Castilla. Madrid, Rivadeneyra. Disponible también como recurso electrónico en:

http://www.cervantesvirtual.com/obra/cortes-de-los-antiguos-reinos-de-leon-y-de-castilla--2/

[Consultado el día 16 de febrero de 2017].

COROLEU, Alejandro (1998): "Humanismo en España”, en Introducción al humanismo renacentista. Madrid. Cambridge University Press, pp. 295-331.

COROMINAS, Joan (1984): Diccionario crítico etimológico castellano e hispánico. Madrid, Gredos.

COUTANT, A. (2007): Une Critique republicaine de la democratie liberale. Paris, Mare at Martin.

CRUZ HERNÁNDEZ, Miguel (1970): “El averroísmo y el origen medieval del espíritu laico”, en Revista de Occidente, 91, pp. 26-37.

DAGGER, Michael (2004) : “Communitarianism and Republicanism”, in Handbook of Political Theory (Gerald F. Gaus and Chandran Kukathas, eds.). Thousand Oaks, Sage Publications, pp. 167-179.

DEYERMOND, Alan (1991): Historia y crítica de la literatura española. Volumen 1 Edad Media (colección dirigida por Francisco Rico). Barcelona, Editorial Crítica. (1985): «Historia universal e ideología nacional en Pablo de Santa María», en Homenaje a Álvaro Galmés de Fuentes, Madrid. Gredos, pp. 313-324.

DOMÍNGUEZ ORTIZ, A. (1949): “Los 'cristianos nuevos'. Notas para el estudio de una clase social", en Boletín de la Universidad de Granada, 87, pp. 249-297.

ECHEVERRÍA, Bolívar (2000) : La modernidad de lo barroco. México, Era. 
EGÍO, Víctor (2015): El pensamiento republicano de Fernando Vázquez de Menchaca. Tesis doctoral defendida en la Facultad de Filosofía de la Universidad de Murcia el 2 de febrero de 2014. Recurso electrónico disponible en https://www.tesisenred.net/handle/10803/287164 [Consultada el 29 abril de 2018].

ENTIN, Gabriel (2018): "Catholic Republicanism: The Creation of the Spanish American Republics during Revolution, en Journal of the History of Ideas, Vol. 79, Núm. 1, enero 2018, pp. 105-123.

(2016): "Introducción al 'Dossier. El republicanismo en el mundo hispánico", Programa Interuniversitario de Historia Política, dossier núm. 79, febrero de 2016. Recurso electrónico http:/historiapolitica.com/dossiers/dossier-el-republicanismo-en-el-mundohispanico/ [Consultado el 16 de enero de 2018].

ELLIOTT, John H. (2006): Empires of the Atlantic World. Britian and Spain in Ametica 14921830. New Haven and London. Yale University Press. (2005): La España Imperial. 1469-1716. Barcelona, Vicens Vives.

ESCUDERO, José Antonio (2005): Estudios sobre la Inquisición. Madrid. Marcial Pons.

ESPOSITO, Roberto (2015): Dos. La máquina de la teología política y el lugar del pensamiento. Buenos Aires, Amorrortu.

FALLOWS, N. (2006): Tratados militares [Selección] de Alonso de Cartagena. Madrid, Ministerio de Defensa. (1991): “Alfonso de Cartagena: An Annotated Tentative Bibliography, en La Coronica, pp. 78-93.

FERNÁNDEZ ALBALADEJO, Pablo (1992): Fragmentos de monarquía: trabajos de historia politica. Madrid, Alianza. 
FERNÁNDEZ GALLARDO, Luis (2018) : “Teología y Derecho en el Defensorium de Alonso de Cartagena", en Comunicación y conflicto en la cultura política peninsular. Siglos XIII al XV (J. M. Nieto Soria, O. Villarroel González, coords.), Madrid, Sílex, pp. 559-595. (2007): “Las ideas políticas de Alonso de Cartagena”, en Res

Publica, 18, pp. 413-426. (2002): Alonso de Cartagena (1385-1456). Una biógrafa politica en la Castilla del siglo XV. Valladolid, Junta de Castilla León.

FERNÁNDEZ LÓPEZ, Jorge (2011): "Humanismo y comentario en la Castilla del siglo XV: Juan de Mena y Alonso de Cartagena”, en Minerva, núm. 24, pp. 17-30.

FERNÁNDEZ SEBASTIÁN, Javier (2016): "Los desaciertos de nuestros padres. Los liberales y la eclosión del llamado «problema español»", en La sombra de la Leyenda Negra, Madrid, Tecnos, pp. 483-510.

FERNÁNDEZ VALLINA, Emiliano (2012): "El tratado De optima politia del Tostado: una visión singular en el siglo XV hispano sobre las formas políticas de gobierno», en Anuario Filosófico, núm. 45-2.

FERNÁNDEZ-SANTAMARÍA, José Antonio (1997): La formación de la sociedad y el origen del Estado: ensayos sobre el pensamiento político español del Siglo de Oro. Madrid, Centro de Estudios Constitucionales.

FLÓREZ, Cirilo (2012): "Política y arte en la fachada de la Universidad de Salamanca", en $L a$ Primera Escuela de Salamanca (1406-1516) (Cirilo Flórez, ed.). Salamanca. Universidad de Salamanca, pp. 117-128. (2007): "El humanismo cívico castellano: Alonso de Madrigal, Pedro de Osma y Fernando de Roa", en Res Publica, 18, pp. 107-139.

FLÓREZ, Enrique (1771), “Alfonso de Cartagena”, en España Sagrada, XXVI, pp. 388-402. 
FONTÁN, A. (1968): "Las tres corrientes del humanismo español”, en Actas del III Congreso Español de Estudios Clásicos, vol. 2, Madrid, Sociedad Española de Estudios Clásicos, pp. 183185.

FORTE, José Manuel (2014): “Republicanismo. El legado clásico”, en Los valores del republicanismo (Jacobo Muñoz, editor). Madrid. Biblioteca Nueva.

FORTEA, José Ignacio (1990): Monarquía y cortes en la Corona de Castilla. Las ciudades ante la politica fiscal de Felipe II. Salamanca, Cortes de Castilla y León.

FOULCHÉ R. (1912-1915): Cancionero castellano del siglo XV. Madrid, Nueva Biblioteca de Autores Hispanos, 19, vol. 1, núm. 288.

FUBINI, Riccardo (2003): Humanism and secularization. From Petrarch to Valla. Durham and London, Duke Universitiy Press.

(1992): "Renaissance Historian: The Career of Hans Baron", en The Journal of Modern History, vol. 64, núm. 3, pp. 541-574.

GARCÍA, Eloy (2002): “Estudio preliminar”, en El momento maquiavélico (Pocock, J. G. A.), Madrid, Tecnos, pp. 11-73.

GARCÍA DE CORTÁZAR, Fernando (2005): Atlas de historia de España. Barcelona, Planeta.

GARIN, Eugenio (1992): La cultura filosfica del Rinascimiento italiano. Firenze, Sansoni Editore. (1982): Ciencia y vida civil en el Renacimiento italiano. Madrid. Taurus. (1981): La revolución intelectual del Renacimiento, Barcelona, Crítica.

GILBERT, Felix (1965): Machiavelli and Guicciardini: politics and History in Sixteenth Century Florence. Princeton, Princeton University Press. 
GIL FERNÁNDEZ, Luis (1997): Panorama social del humanismo español (1500-1800). Madrid, Tecnos.

GIL PUJOL, Xavier (2008): “Concepto y práctica de república en la España moderna. Las tradiciones castellana y catalano-aragonesa", en Estudis. Revista de historia moderna, núm. 34, pp. 111-148.

(2002): "Republican Politics in Early Modern Spain: The Castilian and Catalano-Aragones Traditions", en Republicanism. A Shared European Heritage (Martin Van Gelderen y Quentin Skinner, eds.). Cambridge, Cambridge University Press, pp. 263-288. (1991): Las claves del absolutismo y el parlamentarismo, 1603-1715.

Barcelona, Planeta.

GILMAN, Stephen (1965): "The 'conversos' and the Fall of Fortune", en Collected Studies in honour of Américo Castro 's $80^{\text {th }}$ year, Oxford, Lincoln Lodge Research Library, pp. 127-136.

GIRÓN-NEGRÓN, Luis M. (2001): Alfonso de la Torre's 'Visión Deleytable'. Philosophical Rationalism and the Religous Imagination in Fifteenth Century Spain. Leiden, Brill, 2001.

GISONDI, Marcello (2016): “Temas en el republicanismo de Maquiavelo y Rousseau”, manuscrito — cedido por el autor - del texto de la ponencia presentada el 22 de septiembre de 2016 en la Facultad de Filosofía de la Universidad Complutense de Madrid en el contexto del Congreso Internacional Populismo versus Republicanismo: Genealogía, Historia, Crítica.

GÓMEZ MORENO, Ángel (1994): España y la Italia de los humanistas. Primeros ecos. Madrid. Gredos. (1985): Edición de Qüestion fecha por el noble y magnífico señor don Íñigo López de Mendoza, Marqués de Santillana y Conde del Real, al muy sabio y noble perlado a don Alfonso de Cartagena, Obipso de Burgos. Respuesta del venerable y sabio señor don Alfonso, Obispo de Burgos, a la cuestión hecha por el magnífico señor Marqués de Santillana), en El Crotalón, núm. 2. 
GÓMEZ RAMOS, Antonio (2007): “El trabajo público de los conceptos”, en Isegoría, 37, pp. 185-196.

GONZÁLEZ-QUEVEDO, Silvia (1982): “Alfonso de Cartagena, una expresión de su tiempo”, en Crítica Hispánica, núm. 4, pp. 1-20.

GONZÁLEZ ROLÁN, Tomás (1996), “Los comienzos del Renacimiento en España: Alfonso de Cartagena”, en Manuel Casado Velarde et. al. (eds.), Scripta Philologica in memoriam Manuel Taboada Cid, A Coruña, Universidade da Coruña.

GONZÁlEZ ROLÁN, T., MORENO, A. Y SAQUERO, P. (2000): Humanismo y teoría de la traducción en España e Italia en la primera mitad del siglo XV. Edición y estudio de la Controversia alphonsiana, Madrid, Ediciones clásicas.

GONZÁLEZ ROLÁN, T., HERNÁNDEZ GONZÁLEZ, F., y SAQUERO, P., (1994):

"Diplomacia y humanismo en el siglo XV", introducción a su edición Allegationes super conquesta Canariae de Alfonso de Cartagena [1436]. Madrid, UNED.

GONZÁLEZ ROLÁN, T. y SAQUERO, P. (1991): “Actitudes renacentistas en Castilla durante el siglo XV: la correspondencia entre Alfonso de Cartagena y Pier Cándido Decembrio”, en Cuadernos de Filología Clásica. Estudios Latinos (Nueva Serie), 1, pp. 195-232.

GONZALO MAESO, David (2001): El legado del judaísmo español. Madrid, Trotta.

GOTO-JONES, Christopher (2008): Re-politicising the Kyoto School as Philosophy. Londres, Routledge.

GROSSI, Paolo (1996): El orden juridico medieval. Madrid, Marcial Pons.

GUALDO ROSA, Lucia (2005): «L'umanesimo civile di Leonardo Bruni: revisionismo 'made in USA'», en Schede Umanistiche, XIX/1, pp. 15-37. 
HALPERIN, Tulio (1961): Tradición política española e ideología revolucionaria de mayo. Buenos Aires, Eudeba.

HANKINS, James (2010): “Exclusivist Republicanism and the Non-Monarchical Republic”, en Political Theory, 38 (49), pp. 452-482.

(2006) "Religion and the Modernity of Renaissance", en Angelo Mazzocco

(ed.) Interpretations of Reniassance Humanism. Leiden. Brill, pp. 137-153.

(2001): estudio preliminar a su edición y traducción de Bruni, Leornardo:

History of the Florentine People), 3 volúmenes, Cambridge-MA., Harvard University Press. (1998): "El humanismo y los orígenes del pensamiento político moderno", en

Introducción al humanismo renacentista. Madrid. Cambridge University Press, pp. 159-189. (1995): “The 'Baron Thesis' after Forty Years and Some Recent Studies of Leonardo Bruni", en The Journal of the History of Ideas, vol. 56, núm. 2, pp. 309-338.

(1994) (ed.): Renaissance Civic Humanism. Princeton. Princeton University Press.

HENSHALL, Nicholas (1996): The Myth of Absolutism: Change and Continuity in Early Modern European Monarchy. Londres, Longman, 1996.

HERRERA, Rafael (2016): “The Lost Modernity: 1436-1439 (Alfonso de Cartagena and Leonardo Bruni)", en Transmodernity: Journal of Peripheral Cultural Production of the LusoHispanic World, 6(2). Recurso electrónico disponible en:

http://escholarship.org/uc/item/61t2c10j [Consultado el 15 de enero de 2016].

HEUSCH, Carlos (1996): "El renacimiento del aristotelismo dentro del humanismo español", en Atalaya, 7, pp. 11-40.

HINSLEY, Francis H. (1972): El concepto de soberanía. Barcelona, Labor.

HÖPFL, Harro (2004): Jesuit Political Thought. The Society of Jesus and the State c. 1540-1640. Cambridge, Cambridge University Press. 
IMPEY, Olga (1972): “Alfonso de Cartagena, traductor de Séneca y precursor del humanismo español”, en Prohemio, III, 3, pp. 473-494.

JAGO, Charles C. (2001): “Tributos y cultura política en Castilla, 1590-1640”, en España, Europa y el mundo atlántico: homenaje a John H. Elliott (Richard Kagan y Geoffrey Parker, eds.). Madrid, Marcial Pons/Junta de Castilla y León, Consejería de Educación y Cultura, 2001, p. $86-87$.

JERICÓ BERMEJO, Ignacio (2012): “¿Escuela de Salamanca y Pensamiento hispánico? ante una propuesta”, en Salmanticensis, núm. 59, pp. 83-114.

JIMÉNEZ CALVENTE, Teresa (2015): “Alonso de Cartagena y la cuarta cuestión del Duodenarium: hacia un ensayo del género del diálogo.”, en eHumanista, núm. 29, pp. 133-151. Recurso electrónico disponible en: http://www.ehumanista.ucsb.edu/sites/secure.1sit.ucsb.edu.span.d7_eh/files/sitefiles/ehumanista/ volume29/7\%20ehum29.viv.jimcalvente.pdf [Consultado el 20 de marzo de 2018]

KAEUPER, Richard, DINGMAN, Paul y SPOSATO, Peter (eds.) (2013): Law, Governance, and Justice: New Views on Medieval Constitutionalism, Leiden, Brill. 2013.

KAMEN, Henry (2014): "Fernando el Católico. Absolutismo e inquisición" en Egido y Laplana (eds.): La imagen de Fernando el Católico en la Historia, la Literatura y el Arte. Zaragoza. Institución Fernando el Católico - CSIC. (2013): La Inquisición española: Mito e historia. Barcelona, Crítica.

KANTOROWICZ, Ernst H. (1985): Los dos cuerpos del rey. Un estudio de teología política medieval. Madrid. Alianza Editorial.

KILCULLEN, John (2014): "Medieval Political Philosophy", entrada para la Stanford Encyclopedia of Philosophy. Stanford, Stanford Universitiy. Recurso electrónico: 
http://plato.stanford.edu/archives/spr2014/entries/medieval-political/ [Consultado el 15 marzo de 2015].

KOECK, Heribert Franz y HERMIDA DEL LLANO, Cristina (2012): “La contribución al desarrollo de la Filosofía del Derecho por parte de la Primera Escuela de Salamanca", en $L a$ Primera Escuela de Salamanca (1406-1516) (Cirilo Flórez ed.). Salamanca. Universidad de Salamanca, pp. 223-237.

KOHUT, Karl (1982): "El humanismo castellano del siglo XV. Replanteamiento de la problemática", en Actas del VII Congreso de la Asociación Internacional de Hispanistas. Roma. Bulzoni, vol. II, pp. 639-647.

KOSELLECK, Reinhart (2010): historia/Historia. Madrid. Trotta. (2003): Aceleración, prognosis y secularización. Valencia, Pre-Textos. (1993): Futuro pasado: para una semántica de los tiempos históricos,

Barcelona, Paidós.

KRAYE, Jill (ed.) (1998): "Filólogos y filósofos", en Introducción al humanismo renacentista. Madrid. Cambridge University Press, pp. 189-211.

KRIEGEL, M. (1994): “Autour de Pablo de Santa María et d'Alfonso de Cartagena: alignement culturel et originalité "converso"', en Revue d'histoire moderne et contemporaine, T. 41e, núm. 2, pp. 197-205.

KRISTELLER, Paul Oskar (1993): El pensamiento renacentista y sus fuentes. Madrid. Fondo de Cultura Económica.

LABAJOS ALONSO, José (2012): "Pedro de Osma y Fernando de Roa: significación histórica", en La Primera Escuela de Salamanca (1406-1516) (Cirilo Flórez ed.). Salamanca. Universidad de Salamanca, pp. 143-162. 
LADERO QUESADA, Miguel Ángel (1999): La España de los Reyes Católicos. Madrid, Alianza Editorial.

LAPESA, Rafael (1982): De la Edad Media a nuestros dias. Madrid, Gredos.

LARA, María Pía (2013): The Disclosure of Politics. New York. Columbia University Press.

LAWRENCE, N. H. (1993): “Alfonso de Cartagena y los conversos”, en Deyermond y Penny, (eds).: Actas del primer Congreso Anglo-Hispano. Tomo II. Literatura. Madrid. Castalia, pp. 103-20.

(1990): "Humanism in the Iberian Peninsula", en A. Goodman y A. Mackay (eds.), The Impact of Humanism in Western Europe, London, Longman, pp. 220-258. (1989): “Alonso de Cartagena and Political Thought in the Fifteenth Century: A Note on the 'Affair of the Canaries', 1436-1437”, en Paper delivered to the Medieval Historians of Iberia. Birmingham, University of Birmingham, pp. 1-24. (1979): Un tratado de Alonso de Cartagena sobre la educación y los estudios literarios. Barcelona, Universidad Autónoma de Barcelona.

LEFEBVRE, Lucien (1993): El problema de la incredulidad en el siglo XVI. La religión de Rabelais. Madrid. Akal.

LIBERA, Alain de (2000): Pensar en la Edad Media. Barcelona. Anthropos.

LICEAGA, Gabriel (2009): "San Pablo en la Filosofía política contemporánea: un estado de la cuestión”, en Revista Realidad, 121, pp. 471-485.

LOVETT, Frank (2016): "Republicanism”, en The Stanford Encyclopedia of Philosophy (Edward N. Zalta, ed.). Recurso electrónico disponible en: https://plato.stanford.edu/archives/spr2016/entries/republicanism [Consultado el 22 de agosto de 2016]. 
LÖWITH, Karl (1956): El sentido de la Historia. Implicaciones teológicas del sentido de la Filosofia de la Historia. Madrid, Aguilar.

MACKAY, A. (1972): "Popular Movements and Pogroms in Fifteenth-Century Castile", en Past and Present, 55, pp. 33-67.

MARAVALL, José Antonio (1994): Las Comunidades de Castilla. Una primera revolución moderna. Madrid, Alianza Editorial.

(1967a): "La idea del cuerpo místico en España antes de Erasmo", en Estudios de Historia del Pensamiento Español. Edad Media. Serie Primera. Madrid, Ediciones Cultura Hispánica.

(1967b): "El concepto de Monarquía en la Edad Media española»", en Estudios de Historia del Pensamiento Español. Edad Media. Serie Primera. Madrid, Ediciones Cultura Hispánica.

(1954): El concepto de España en la Edad Media. Madrid,

Madrid. Instituto de Estudios Políticos.

MARCANO, Enrique (2000): "Del republicanismo clásico al republicanismo moderno. Juan de Mariana y la tradición republicana", en Poder y modernidad. Concepciones de la política en la España moderna (Javier Peña, coord.). Valladolid, Universidad de Valladolid, pp. 127-165.

MARICHAL, Juan (1984): «El proceso articulador del siglo XV: de Cartagena a Pulgar», en Teoría e historia del ensayismo hispánico. Madrid, Alianza Editorial, pp. 22-26.

MÁRQUEZ VILlANUEVA, Francisco (2004): "La Celestina y los «desarrados»", en Siglos dorados. Homenaje a Agustín Redondo (Pierre Civil, coord.). Madrid, Castalia, pp. 889-902. (1993): "Nascer e morir como bestias (criptojudaísmo y criptoaverroísmo)", en Los judaizantes en Europa y la literatura castellana del Siglo de Oro. Madrid, Letúmero, pp. 273-293. (1965): “The Converso Problem: An Assessment”, en Collected Studies in honour of Américo Castro's $80^{\text {th }}$ year (M.P. Hornik, ed.). Oxford, Lincoln Lodge Research Library, pp. 317-333. 
MARTÍN GÓMEZ, María (2018): entrevista en La Crónica de Salamanca, publicada el 13 de mayo de 2018. Recurso electrónico disponible en: http://lacronicadesalamanca.com/203792-elpensamiento-democratico-nacio-en-salamanca/ [Consultado el 13 de mayo de 2018]. (2017): La escuela de Salamanca, fray Luis de León y el problema de la interpretación. Navarra, Eunsa. (2011): "La introducción en España de la historia conceptual”, en Azafea. Revista de Filosofía. 13, pp. 257-276.

MATE, Reyes y ZAMORA, José A. (eds.) (2006): Nuevas teología políticas. Pablo de Tarso en la construcción de Occidente. Barcelona, Anthropos.

MEDINA, José (2012): "Hermeneutical Injustice and Polyphonic Contextualism: Social Silences and Shared Hermeneutical Responsibilities", en Social Epistemology, vol. 26, núm. 2, abril 2012, pp. 201-220.

MEGÍAS QUIRÓS, José J. (1992): La teoría política entre la Edad Media y la Edad Moderna. Alonso de Castrillo. Cádiz, Universidad de Cádiz.

MEINECKE, Friederich (1983): La idea de razón de estado en la Edad Moderna. Madrid, Centro de Estudios Constitucionales.

MENÉNDEZ PELAYO, Marcelino (1995): Historia de los heterodoxos españoles. México. Porrúa. (1952): entrada “Alonso de Cartagena”, en Biblioteca de traductores españoles. Abenatar-Cortés. Santander, Consejo Superior de Investigaciones Científicas.

MERLO, Maurizio (1998): "La ambivalencia de los conceptos. observaciones acerca de algunas relaciones entre Begriffsgeschichte e historiografía del discurso político.”, en Res publica, 1, pp. 87-101. 
MIGUEL, Jerónimo (2018): "Los espacios de la ciencia y el saber en la Castilla del siglo XV. Dos testimonios representativos.: Alfonso de Cartagena y Juan de Lucena”, en Espacios en la Edad Media y el Renacimiento (María Morrás, editora), Salamanca, Sociedad de Estudios Medievales y Renacentistas - Universidad de Salamanca, pp. 281-298.

MIETHKE, Jürgen (1993): Las ideas políticas de la Edad Media. Buenos Aires. Biblios.

MONSALVO, José María (2010): "Poder y cultura en la Castilla de Juan II: ambientes cortesanos, humanismo autóctono y discursos políticos”, en Salamanca y su Universidad en el primer Renacimiento: siglo XV (Rodríguez-San Pedro y Polo, coords.). Salamanca, Universidad de Salamanca, pp. 15-91.

MORRÁS, María (2002a): “La trasmisión textual de las traducciones de Cicerón hechas por Alonso de Cartagena”, en Alvar, C. y Lucía Megías, J. M.: Diccionario filológico de literatura medieval española. Textos y transmisión. Madrid. Castalia.

(2002b): "El debate entre Leonardo Bruni y Alonso de Cartagena: las razones de una polémica", en Quaderns. Revista de Traducció, 7, pp. 33-57.

(1996): Prólogo a su edición de Alonso de Cartagena: Libros de Tulio: De senetute, De los ofiçios. Alcalá de Henares, Universidad de Alcalá. (1995): «Sic et non: Alfonso de Cartagena y los studia humanitatis», en Euphrosyne, XXIII. pp. 333-346. (1991): "Repertorio de obras, mss y documentos de Alfonso de Cartagena (ca. 1384-1456)", en Boletín Bibliográfico de la Asociación Hispánica de Literatura Medieval, cuaderno bibliográfico núm. 5, pp. 213-245.

MOULAKIS, Athanasios (2011): "Civic Humanism" en The Stanford Encyclopedia of Philosophy (Edward N. Zalta, ed.). Recurso electrónico disponible en: http://plato.stanford.edu/archives/win2011/entries/humanism-civic/ [Consultado el 21 de agosto de 2016]. 
NANU, Irina (2013): La Segunda Partida de Alfonso X El Sabio y la tradición de los Specula Principum, tesis doctoral presentada en la Universidad de Valencia. Recurso digital disponible en:

http://roderic.uv.es/bitstream/handle/10550/29240/Tesis\%20doctoral_INanu.pdf?sequence=1\&is Allowed=y [Consultado el 9 de octubre de 2017].

NETANYAHU, Benzion (2005): De la anarquía a la Inquisición: estudios sobre los conversos en España durante la Baja Edad Media. Madrid, Esfera de los Libros. (2000): Los orígenes de la Inquisición española del siglo XV.

Barcelona, Crítica.

NIETO SORIA, José Manuel (2005): "Rex inutilis y tiranía en el debate político de la Castilla bajomedieval', en Coups d'État a la fin du Moyen Age? Aux fondements du pouvoir politique en Europe occidentale (François Foronda, Jean Philippe Genet y José Manuel Nieto Soria, eds.). Madrid, Casa de Velázquez, pp. 73-92.

(1998): "El «poderío real absoluto» de Olmedo (1445) a Ocaña (1469): La monarquía como conflicto", en En la España medieval, núm. 21, 159-228.

(1993): "Las concepciones monárquicas de los intelectuales conversos en la Castilla del siglo XV", en Espacio, Tiempo y Forma, Serie III, Historia Medieval, t. 6., pp. 229-248.

(1988): Fundamentos ideológicos del poder real en Castilla (Siglos XIII-XVI). Madrid, Eudema.

OLIVERA, César (1987): "Las Cortes de Castilla en el primer tercio del siglo XV”, en Hispania, XLVII, pp. 437-444.

(1986): Las Cortes de Castilla y León y la crisis del reino (1445-1474): El registro de Cortes. Burgo, Cortes de Castilla y León.

OLIVETTO, Georgina (2010): “Alonso de Cartagena y el humanismo”, en Letras, núm. 61-62, pp. 231-244, 2010. Recurso digital http://bibliotecadigital.uca.edu.ar/repositorio/revistas/alonsode-cartagena-el-humanismo.pdf [Consultado el 19 de agosto de 2016]. 
OLMEDO, Félix (1958): “Don Alfonso de Cartagena (1384-1456), tratadista y hombre de acción”, en Manresa, núm. 30, pp. 31-48.

ONCINA, Faustino (1998): “Experiencia y política en la historia conceptual”, en Res publica, 1, pp. 103-119.

PAGDEN, Anthony (1991): El imperialismo español y la imaginación política. Barcelona. Planeta. (1987) (ed.): The Languages of Political Theory in Early-Modern Europe.

Cambridge, Cambridge University Press.

(1975): “The Difusión of Aristototle’s Moral Philosophy in Spain, ca. 1400-ca.1600”, en Traditio, 31, pp. 287-313.

PALTI, Elías (2012): “En los pliegues de lo sagrado. Una genealogía de lo político en el mundo hispánico", en Les Empires atlantiques en révolution. Une perspective transnationale (Clément Thibaud, Gabriel Entin, Alejandro Gómez y Federica Morelli, dirs.). París, La Perséides, pp. 205-235.

(2002): "Las polémicas en el liberalismo argentino. Sobre virtud, republicanismo y lenguaje", en El republicanismo en Hispanoamérica. Ensayos de historia intelectual y política (José Antonio Aguilar Rivera y Rafael Rojas, coords.). México, Fondo de Cultura EconómicaCentro de Investigación y Docencia Económicas, pp. 167-209.

PANI, Érika (2009): “Maquiavelo en el Septentrión. Las posibilidades del republicanismo en Hispanoamérica”, en Prismas, núm. 13, pp. 295-300.

PANGLE, Thomas (1988): The Spirit of Modern Republicanism: The Moral Vision of the American Founders and the Philosophy of Locke. Chicago, Chicago University Press.

PASTORE, Stefania (2004): Un'eresia spagnola. Spiritualità conversa, alumbradismo e Inquisizione (1449-1559). Firenze, Leo S. Olschki Editore. 
PASSERIN D'ENTREVÈS, Alessandro (2001): La Noción del Estado. Barcelona, Ariel.

PECCHIOLI, Renzo (1986): “Tra Gog e Magog: i pericoli della storiografia republicana”, en Rivista Storica Italiana, 98, 1, pp. 147-194.

(1983): “Dal «mito» di Venezia all' «ideologia americana»: itinerari e modelli della storiografia sul republicanismo dell'età moderna". Venezia, Marsilio Editori.

PENA, Miguel-Anxo (2009): La Escuela de Salamanca. De la Monarquía Hispánica al orbe católico. Madrid, BAC. (2008): Aproximación bibliográfica a la(s) «Escuela(s) de Salamanca». Salamanca . Universidad Pontificia de Salamanca.

PENNA, Mario (ed.) (1959): Prosistas castellanos del siglo XV. Biblioteca de Autores Españoles, 116. Madrid, Atlas.

PEÑA, Javier (2000): Poder y modernidad. Concepciones de la política en la España moderna. Valladolid, Universidad de Valladolid.

PERALTA, Ramón (2010): La Ley Perpetua de la Junta de Ávila (1520). Madrid, Actas Editorial.

PEREZ, Joseph (2012): Breve historia de la Inquisición en España. Barcelona. Planeta. (1993): Historia de una tragedia: la expulsión de los judíos de España.

Barcelona, Crítica.

PÉREZ CABALLERO, Jesús (2017): De Roma a Roma. Un ensayo de sistematización de los crímenes de lesa majestad, nación y humanidad. Granada, Editorial Comares.

PÉREZ HERRANZ, Fernando (2016): Lindos y tornadizos. El pensamiento filosófico hispánico (siglos $X V$-XVII). Madrid, Verbum. 
PETTIT, Philip (1999): Republicanismo: una teoría sobre la libertad y el gobierno. Barcelona. Paidós.

POCOCK, J. G. A. (2002): El momento maquiavélico. Madrid, Tecnos. (1989): "Civic Humanism and its Role in Anglo-American Thought", en Politics, Language, and Time: Essays on Political Thought and History. Chicago, Chicago Universitiy Press.

QUIJANO, Francisco (2018): “Thinking the political community in 16th century New Spain. A work program for intellectual history", en Signos Históricos, vol. XX, núm. 39, pp. 24-49. (2017): Las repúblicas de la monarquía. Pensamiento constitucionalista y republicano en Nueva España (1550-1610). Cuidad de México, UNAM - Instituto de Investigaciones Históricas.

(2015): "Ser libres bajo el poder del rey. El republicanismo y constitucionalismo de Bartolomé de Las Casas", en HMex, núm. LXV: 1, pp. 7-64.

REVUELTA, M. (1986) (ed.): El erasmismo en España. Santander, Sociedad Menéndez Pelayo.

RICO, Francisco (1993): El sueño del humanismo. De Petrarca a Erasmo. Madrid, Alianza. (1978): Nebrija frente a los bárbaros. Salamanca, Ediciones Universidad de Salamanca.

RIVERA, Antonio (2012): "Humanismo, representación y angelología. El conciliarismo de Juan de Segovia”, en La Primera Escuela de Salamanca (1406-1516) (Cirilo Flórez ed.). Salamanca. Universidad de Salamanca, pp. 95-113. (2011): "La Constitución mixta, un concepto político premoderno", en Historia y Política, núm. 26, julio-diciembre 2011, Madrid, Centro de Estudios Políticos y Constitucionales, pp. 171-197.

(2007): "Polifonía política medieval: orden, justicia y gobierno en algunos tratados castellanos", en Res Publica, núm. 18, pp. 83-105. 
(2002): "Libertad, democracia y religión en el debate neorrepublicano", en Res Publica, núm. 9-10, pp. 205-237.

(2001): “Teología política: consecuencias jurídico políticas de la Potentia Dei”, en Daimon. Revista de filosofia, núm. 23, pp. 171-184.

RODGERS, Daniel (1992): "Republicanism: The Career of a Concept", en The Journal of American History, vol. 79, núm. 1, pp. 11-38.

RODRÍGUEZ-SAN PEDRO, Luis Enrique (2014): La Universidad de Salamanca en el primer Renacimiento, 1380-1516. Salamanca, Centro de Estudios Salmantinos. (2006) (coord.): Historia de la Universidad de Salamanca. Salamanca, Universidad de Salamanca. (1995): "Las universidades de Castilla" en Historia de una cultura. La singularidad de Castilla (Agustín García Simón y José Ortega, coords.) Valladolid, Junta de Castilla y León, Consejería de Cultura y Turismo, vol. 2, pp. 411-459. (1991): "La Universidad de Salamanca: evolución y declive de un modelo clásico”, en Studia Historica. Historia Moderna, núm. IX, pp. 9-21.

RODRÍGUEZ-SAN PEDRO, Luis y POLO RODRÍGUEZ, Juan (coords.) (2010): Salamanca y su Universidad en el primer Renacimiento: siglo $X V$. Salamanca, Universidad de Salamanca. (2006): Universidades

clásicas de la Europa mediterránea: Bolonia, Coímbra y Alcalá. Salamanca, Universidad de Salamanca.

RODRÍGUEZ VELASCO, Jesús D. (2009): Ciudadanía, soberanía monárquica y caballería: Poética del orden de caballería. Madrid. Akal.

ROJAS, Luis (2000): “Alonso de Cartagena, jurista y diplomático del humanismo español”, en Revista de estudios histórico-jurídicos, núm. 22. Recurso electrónico disponible en: https://scielo.conicyt.cl/scielo.php?script=sci_arttext\&pid=S0716-54552000002200005 [Consultado el 26 abril de 2016] 
ROSATI, Massimo (2009): Ritual and the Sacred. A Neo-Durkheimian Analysis of Politics, Religion and the Self. Farnham, Ashgate.

ROUND, Nicholas (1969): «Politics, Style and Group Attitudes in the Instrucción del Relator», en Bulletin of Hispanic Studies, 46, p. 292 y ss.

(1966): «La rebelión toledana de 1449. Aspectos ideológicos», en Archivum,

XVI, pp. 385-446.

(1962), "Renaissance Culture and its Opponents in Fifteenth-Century

Castile", en Modern Language Review, 57, pp. 204-215.

RUBIÉS, Joan Pao (1996): "La idea del gobierno mixto y su significado en la crisis de la Monarquía hispánica”, en Historia Social, núm. 24 pp. 57-81.

RUIZ, Ramón (2013): “El republicanismo clásico en el pensamiento hispano: Comentarios sobre una tradición frustrada”, en Anales de la Cátedra Francisco Suárez, n. 47, pp. 273-297.

RUSSELL, Peter Edward (1978): "Las armas contra las letras: para una definición del humanismo español del siglo XV”, en Temas de «La Celestina» y otros estudios. Del «Cid» al «Quijote» poner bien esta ref., Barcelona, Ariel, pp. 207- 239.

(1973): Spain: a companion to Spanish studies. Nueva York, Pitman. (1972): «El descubrimiento de las Canarias y el debate medieval acerca de los derechos de los príncipes y pueblos paganos», en Revista de Historia Canaria, XXXVI, pp. 9-32.

RUSSELL, Peter Edward y PAGDEN, Anthony (1974): "Nueva luz sobre una versión de la Ética a Nicómaco", en Homenaje a Guillermo Gustavino. Madrid, Asociación Nacional de Bibliotecarios, Archiveros y Arqueólogos.

SABINE, G. (1982): Historia de la teoría política, Madrid, Fondo de Cultura Económica. 
SALAZAR, Abdon M., (1976): "El impacto humanístico de las misiones diplomáticas de Alonso de Cartagena en la Corte de Portugal entre medievo y renacimiento (1421-31)", en Deyermond (ed.): Medieval Hispanic Studies presented to Rita Hamilton. Londres, Tamesis Books, pp. 215226.

SCHAMBECK, Herbert y HERMIDA DEL LLANO, Cristina (2012): "La recepción del iusnaturalismo tomista en la Primera Escuela de Salamanca", La Primera Escuela de Salamanca (1406-1516) Cirilo Flórez (ed.) Salamanca. Universidad de Salamanca, pp. 211-222.

SCHMITT, Carl (2009): Teología política. Madrid, Trotta.

SERRANO, L. (1942): Los conversos D. Pablo de Santamaría y D. Alonso de Cartagena, obispos de Burgos, gobernantes, diplomáticos y escritores. Madrid, Escuela de Estudios Hebraicos.

SICROFF, Albert (1982): "El Lumen ad revelationem gentium, de Alonso de Oropesa, como precursor del erasmismo en España”, en Actas del cuarto Congreso Internacional de Hispanistas, Salamanca, Universidad de Salamanca, págs. 655-664. (1985): Los estatutos de limpieza de sangre. Controversias entre los siglos XV y XVII. Madrid, Taurus.

SIEGEL, Daniel J. (1966): “'Civic Humanism’ or Ciceronian Rethoric? The culture of Petrarch and Bruni”, en Past and Present Society, núm. 34, pp. 3-48.

SKINNER, Quentin (2010): “Una genealogía del Estado Moderno”, en Estudios Públicos, núm. 118, recurso electrónico disponible en http://www.cepchile.cl/una-genealogia-del-estadomoderno/cep/2016-03-04/095237.html [Consultado el 14 de abril de 2016]. (2004) “The Rediscovery of Republican Values", en Visions of Politics. Renaissance Virtues. Cambridge University Press, pp. 10-38. 
(2002): "Meaning and Understanding in the History of Ideas", en Visions

of Politics. Volume I. Regarding Method. Cambridge, Cambridge University Press, 2002, pp. 5789. (1999): Liberty before Liberalism. Cambridge. Cambridge University

Press.

(1985): Los fundamentos del pensamiento politico moderno. México,

Fondo de Cultura Económica.

STRAUSS, Leo (2009): La persecución y el arte de escribir. Buenos Aires, Amorrortu. (2005): Sobre la tiranía. Madrid. Ediciones Encuentro.

SUÁREZ FERNÁNDEZ, Luis (1991): La expulsión de los judios de España, Madrid. Editorial Mapfre.

(1964): Documentos acerca de la expulsión de los judios.

Valladolid, CSIC.

SVERLIJ, Mariana (2013): "Modernidad y humanismo civil: debates y perspectivas en torno a la tesis de Baron", en Anuario de la Escuela de Historia, Año 4, vol. 4, pp. 21-34.

TATE, Robert B. (1985): estudio preliminar de la edición de Claros varones de Castilla de Fernando del Pulgar. Madrid, Taurus.

(1970): “La Anacephaleosis de Alfonso García de Santa María, obispo de Burgos, 1435-1456", en Ensayos sobre la historiografía peninsular del siglo XV. Madrid, Gredos, pp. 5573.

TELLKAMP, Jörg Alejandro (2014): "Francisco de Vitoria and Luis de Molina on the Origin of Political Power", en Right and Nature in the First and Second Scholasticism. Turnhout-Belgium, Brepols Publishers, pp. 231-247. (2004): "Filosofía política en la Edad Media", en Estudios de Filosofía Política (Luis Eduardo Hoyos, ed.), Bogotá, Universidad Nacional de Colombia, pp. 79-102. 
THIEBAUT, Carlos (1990): Historia del nombrar: dos episodios de la subjetividad moderna. Madrid, Visor. (1989): "Sujeto complejo, identidad narrativa, modernidad del Sur”, en Castilla del Pino (comp.): Teoría del personaje. Madrid, Alianza.

THOMPSON, I.A.A. (1981): Guerra y decadencia. Gobierno y administración en la España de los Austrias, 1560-1620. Barcelona, Crítica.

TIERNO GALVÁN, Enrique (1971): De las comunidades o la historia como proceso, en Escritos (1950-1960). Madrid. Tecnos.

TORREGROZA, Enver (2010): “Los aportes de los intelectuales conversos Pablo de Santamaría y Alonso de Cartagena a la filosofía política hispánica”, en Formas de Hispanidad (Torregroza y Ochoa, eds.). Bogotá, Universidad del Rosario, pp. 163-194. (2008): “El papel filosófico y político de los judeoconversos en la formación del pensamiento hispánico", en La llave de las Españas (VV.AA.). Bogotá, Universidad del Rosario, pp. 41-62.

TORRES, Sebastián (2013): “¿Un momento maquiaveliano en Arendt? Republicanismo y revolución”, en Cadernos de Filosofia Alemã, v. 21, núm. 3, pp.123-140.

ULLMAN, Walter (1985): Principios de gobierno y política en la Edad Media. Madrid, Alianza. (1984): Historia del pensamiento político en la Edad Media. Barcelona, Ariel.

UNAMUNO, Miguel de (1986): El sentimiento trágico de la vida. Madrid, Alianza.

UTRERA, Juan Carlos (2005): “Introducción”, en Conciliarismo y constitucionalismo. Selección de textos I. Los orígenes del pensamiento constitucionalista (Juan Carlos Utrera, ed.). Barcelona, Marcial Pons, pp. 9-40. 
VALERO MORENO, Juan Miguel (2018): “Alfonso de Cartagena y la corte literaria de Juan II: apuntes para una revisión historiográfica", en Espacios en la Edad Media y el Renacimiento (María Morrás, editora), Salamanca, Sociedad de Estudios Medievales y Renacentistas Universidad de Salamanca, pp. 351-36.

VALLESPÍN, Fernando (2002): "Historiografía republicana”, en El país, publicado el 23 de noviembre de 2002. Recurso electrónico disponible en: https:/elpais.com/diario/2002/11/23/babelia/1038010628_850215.html [Consultado el 5 de diciembre de 2017].

VALLET DE GOYTISOLO, Juan (1980) (coord.): El pactismo en la historia de España. Madrid, Instituto de España.

VAN GELDEREN, Martin y SKINNER, Quentin (2002) (eds.): Republicanism. A Shared European Heritage. Cambridge, Cambridge University Press.

VARELA-PORTÁS, Juan (2016): “El Humanismo, ¿es un populismo?”, conferencia pronunciada el 22 de septiembre de 2016 en el congreso Populismo vs. Republicanismo: genealogía, historia, crítica, celebrado en la Facultas de Filosofía de la Universidad Complutense de Madrid entre el 20 y el 23 de septiembre de 2016.

VASOLI, Cesare (1979): “The Machiavellian Moment: A grand ideological synthesis”, en Journal of Modern History, 49, 4, pp. 664-670.

VELASCO, Ambrosio (2006a): Republicanismo y multiculturalismo, México, Siglo XXI (2006b): "La tradición republicana novohispana del siglo XVI", en La vigencia del republicanismo (A. Velasco, E. Di Castro y M. J. Bertomeu, coords.). México, UNAM, pp. 25-39. 
VERDÍN-DÍAZ, Guillermo (1993): “Introducción”, en su edición y traducción al castellano del Defensorium Unitatis Christianae de Alonso de Cartagena. Oviedo, Universidad de Oviedo, pp. 15-100.

VICENS VIVES, J. (2003): Juan II de Aragón: monarquía y revolución en la España del siglo $X V$. Pamplona, Urigoiti Editores.

VICKERS, B. (1990): Mentalidades ocultas y científicas en el Renacimiento. Madrid, Alianza Editorial, pp. 63-144.

VILLACAÑAS, José Luis (2017): "Republicanismo y modernidad: una perspectiva comparada de los casos españoles (siglos XII- XVIII)". Repositorio digital Universitat Pompeu Fabra. Recurso electrónico disponible en:

https://repositori.upf.edu/bitstream/handle/10230/33363/villacanas_republicanismo.pdf?sequence =1\&isAllowed=y [Consultado el 2 de mayo de 2017].

(2016): Teología política imperial y comunidad de salvación cristiana. Una genealogía de la división de poderes. Madrid, Trotta.

(2016b): "Los supuestos de la teoría populista de Laclau: psicoanálisis y sociedad", ponencia presentada el 22 de septiembre de 2016 en la Facultad de Filosofía de la Universidad Complutense de Madrid en el contexto del Congreso Internacional Populismo versus Republicanismo: Genealogía, Historia, Crítica. (2014): Historia del poder político en España. Barcelona, RBA. (2012): "La ratio teológico paulina de Alonso de Cartagena", en Cirilo Flórez (ed.): La Primera Escuela de Salamanca (1406-1516). Salamanca, Universidad de Salamanca, pp. 75-95.

(2012b): "El programa de traducción de Alfonso de Cartagena y la fundación de la mentalidad castellana." en Los Cinco Libros de Séneca. Alfonso de Cartagena. Murcia, Tres fronteras ediciones.

(2012c): "Spinoza: Democracia y subjetividad marrana", recurso digital http://quod.lib.umich.edu/p/pc/12322227.0001.003/--spinoza-democracia-y-subjetividadmarrana?rgn=main;view=fulltext [Consultado el 12 de octubre de 2016]. 
(2008): La monarquía hispánica (1284-1516). Madrid, Espasa.

(2005): "El republicanismo clásico en España: Las razones de una ausencia”, en Journal of Spanish Cultural Studies, vol. 6, núm 2, pp. 163-183.

(2005b): "Disciplinar la violencia, ordenar la milicia Sobre el problema de la caballería en la crisis del siglo XV" publicado por Biblioteca Saavedra Fajardo. Recurso electrónico disponible en: http://www.saavedrafajardo.org/Archivos/NOTAS/RES0033.pdf [Consultado el 11 de marzo de 2016].

(2005c): "La fortuna de Cicerón en Castilla hasta la modernidad", publicado por Biblioteca Saavedra Fajardo. Recurso electrónico disponible en: http://www.saavedrafajardo.org/Archivos/NOTAS/RES0037.pdf [Consultado 11 de marzo 2016].

(2004): Reseña a la traducción de Alonso de Cartagena de De oficcis http://www.saavedrafajardo.org/Archivos/NOTAS/RES0011.pdf

WEBER, Max (2011): La ética protestante y el espiritu del capitalismo (edición de Francisco Gil Villegas). México, Fondo de Cultura Económica.

VIROLI, Maurizio (2015): Republicanismo. Santander, Ediciones Universidad de Cantabria. (1992): From Politics to Reason of State: The Acquisition and

Transformation of the Language of Politics. Cambridge, Cambridge University Press.

YNDURÁIN, Domingo (1994): Humanismo y Renacimiento en España. Madrid, Cátedra.

YOVEL, Yirmiyahu (2009): The Other Within. The Marranos: Split Identity and Emerging Modernity. Princeton, Princeton University Press.

(1992): Spinoza and other heretics. The marrano reason. Princeton,

Princeton University Press.

ZUCKERT, Michael (1994): Natural Rights and the New Republicanism. Princeton, Princeton University Press. 
Pensamiento político converso en la Castilla del siglo XV y su impronta en la Modernidad hispánica: Teología política y

pensamiento republicano en el

Defensorium unitatis

christianae de Alonso de

Cartagena.

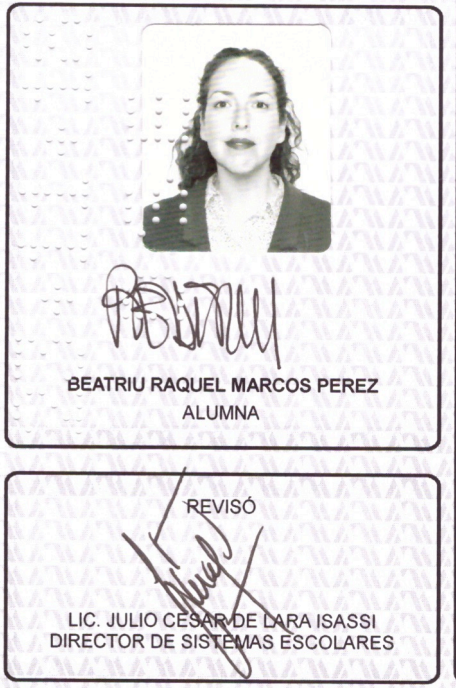

En la Ciudad de México, se presentaron a las 13:00 horas del día 15 del mes de noviembre del año 2018 en la Unidad Iztapalapa de la Universidad Autónoma Metropolitana los DRA. TERESA SANTIAGO OROPEZA DRA. TERESA SANTIAGO OROPEZA DR. JOERG ALEJANDRO TELLKAMP

Bajo la Presidencia de la primera y con carácter de Secretario el último, se reunieron a la presentación de la Disertación pública cuya denominación aparece al margen, para la obtención del grado de:

DOCTORA EN HUMANIDADES (FILOSOFIA)

DE: BEATRIU RAQUEL MARCOS PEREZ

y de acuerdo con el articulo 78 fracción IV del Reglamento de Estudios Superiores de la Universidad Autónoma Metropolitana, los miembros del jurado resolvieron:

\section{APROBAR}

Acto continuo, la presidenta del jurado comunicó a la interesada el resultado de la evaluación y, en caso aprobatorio, le fue tomada la protesta. 